\title{
Dissertation
}

\section{Touts and Despots: \\ Recruiting Assemblages of Contract Labour in Fernando Pó and the Gulf of Guinea, 1858-1979}

\author{
zur Erlangung des akademischen Grades \\ doctor philosophiae \\ (Dr. phil.) \\ Kultur-, Sozial- und Bildungswissenschaftlichen Fakultät \\ Enrique Martino
}

Präsident der Humboldt-Universität zu Berlin

Prof. Dr. Jan-Hendrik Olbertz

Dekanin der Kultur-, Sozial- und Bildungswissenschaftlichen Fakultät

Prof. Dr. Julia von Blumenthal

Gutachter: 1. Prof. Dr. Andreas Eckert

2. Prof. Dr. Alexander Keese

Datum der Einreichung: 18 November 2015

Tag der mündlichen Prüfung: 22 April 2016 


\section{Abstract}

This dissertation follows Fernando Pó's labour recruiters wherever they wentbetween the 1860s and 1920s recruiters traversed the entirety of the Gulf of Guinea and enlisted mostly Kru from Liberia and Fang from Rio Muni, Cameroon and Gabon; between the 1930s to 1960s they gathered particularly around the Bight of Biafra and brought an unprecedented number of contract workers into the island's booming cacao plantations, mostly Igbos and Ibibios from south-eastern Nigeria. Recruiters tended to appear in a modality that I will describe and theorize as 'touts'. They operated almost exclusively with an excess of language and money-deceit and informal advances. They operated 'outside' the law and the regulated, yet it was only the shape of the contract on Fernando Pó-forced, long and irrevocable - that allowed recruiters to deploy their techniques. Recruiters created and relayed a series of wholly impermissible twists: quasi-enslavement through fraud that was a form of kidnapping, quasi-debt bondage with informal wage advances enabled by the contracts, and even a movement of really quite free but fugitive labour across borders and work-sites. A sustained attention on the ambivalent practices of recruiters reveal a series of juxtapositions of free and unfree that produced creative potentials for intensification and unravelling, rather than single points along a 'free-unfree' labour spectrum.

Keywords: Equatorial Guinea, West Africa, Contract Labour, Recruiters, Free and Unfree Labour

Diese Dissertation folgt Fernando Pó Arbeitskraftanwerbern wohin sie auch gingen dort, wo sie zwischen den 1860er und 1920er Jahren den gesamten Golf von Guinea überquerten und hauptsächlich Kru von Liberien und Fang von Rio Muni, Kamerun und Gabon anwarben; und dort, wo sie ab den 1930er bis 1960er Jahren vor allem um die Bucht von Biafra eine noch nie dagewesene Anzahl an Vertragsarbeitern, vor allem Igbos und Ibibios aus dem südöstlichen Nigeria auf die florierenden Kakaoplantagen der Insel brachten. Die Anwerber tauchten vornehmlich als eine Modalität auf, die ich als 'tout' beschreibe und theoretisiere. Diese operierten fast ausschließlich mittels eines Exzesses an Sprache und Geld - mittels Täuschung und informellen Vorschüssen. Zwar agierten sie 'außerhalb' des Rechts, doch erlaubte genau die Vertragsform von Fernando Pó, die langfristig und unwiderruflich zur Arbeit zwang, den Anwerbern die Ausübung ihrer Techniken. Eine Reihe an unerlaubten Verdrehungen wurden 
geschaffen und durchgereicht: Quasi-Versklavung durch Täuschung in Form von Kidnapping, Quasi-Schuldknechtschaft mittels informellen Lohnvorschüssen, die die Verträge ermöglichten sowie die grenz- und Arbeitsort überschreitende Migration einer relativ freien, allerdings flüchtigen Arbeitskraft. Der anhaltende Blick auf die ambivalenten Praktiken der Anwerber legt eine Reihe an Nebeneinandern von ,frei' und ,unfrei' offen, was kreative Potentiale für deren Intensivierung und Auflösung schuf, und über einzelne Punkten entlang eines Spektrums der freien-unfreien Arbeit hinausgeht.

Schlagwörter: Äquatorialguinea, Westafrika, Vertragsarbeit, Anwerber, freie und unfreie Arbeit 


\section{Acknowledgements}

This dissertation formally began in 2010 at the Institute of African Studies of the Humboldt University in Berlin. In 2011 I joined the research group "Forced Labour Africa: An Afro-European Heritage in Sub-Saharan Africa (1930-1975)" funded by the ERC Starting Grant no. 240898 under Framework Programme 7 of the European Commission. My gratitude goes first and foremost to my two supervisors; Andreas Eckert who took me in at the beginning even though I only possessed a vague plan and little motion; being around The International Research Center 'Work and Human Lifecycle in Global History' (Re:work) has been a real boon and provided a constant beam of insight for my investigations; and Alexander Keese, head of the research group that provided an inordinate amount of support and made all the field work possible.

For being there from the early stages or really throughout many other key parts, I thank Benita Sampedro, Dmitri van den Bersselaar and William Clarence-Smith; a big wholehearted thank you. In the critical first phase of getting the plan for a thesis off the ground, with all its self-induced false starts, I am still forever grateful to Peter Hallward, Ulrich Fleischmann and Michael Zeuske. At the Institute of African Studies I am also forever grateful to Joël Glasman, Michael Pesek, and Ineke Pfaff-Rheinberger for their very helpful orientations and advice.

At the AGA, the archive, in Alcalá de Henares, I thank Juan José Villar Lijarcio for revealing the existence of their internal digital index that made the quasi-unnavigable Guinea section actually accessible through their staff-only search engine, 'interpares'. Thanks also to Ana Naseiro Ramudo, the chief cataloguist of the new Guinea index, that is still under construction, for explaining how it was exactly that large swathes of the Republican and Francoists colonial archives never made it into the only publicly available catalogue. In Equatorial Guinea I would like to thank many people but I should only publicly acknowledge the official institutions: the Biblioteca Nacional de Malabo, the Universidad Nacional de Guinea Ecuatorial and the Spanish cultural centre in Bata, without which getting the visas would have been close to impossible. Similarly, for helping me to know and travel to the Nigerian archives in Enugu and Calabar, I thank Simon Heap, David Aworawo, David Pratten, Axel Harneit-Sievers, Chima Korieh, Gloria Chuku, Ute Röschenthaler, David Imbua, Nnanna Onuoha Arukwe and Edlyne Anugwom. 
At the writing stage, as parts of the text have been prepared for publication in journals (specifically the articles "Panya: Economies of Deception and the Discontinuities of Indentured Labour Recruitment and the Slave Trade, Nigeria and Fernando Pó, 1890s1940s", to appear in a future issue of the journal African Economic History, and "DashPeonage: The Contradictions of Debt Bondage on the Colonial Plantations of Fernando Pó", to appear in a future issue of Africa: Journal of the International African Institute) I wish to thank various people for various comments on these article drafts, and especially Ugo Nwokeji, Paul Lovejoy, David Pratten, Chika Onyenezi, Jelmer Vos, Cassandra Mark-Thiesen, as well Bill Freund, Stefano Bellucci, Zachary Kagan Guthrie, Prabhu Mohapatra, Keith Breckenridge, Barbara Cooper, Cheikh Babou and Benoît Henriet.

I am thankful to Juan Aranzadi, Gustau Nerín and Gonzalo Alvarez Chillida for including me, since early 2014, in the research group based out of the UNED in Madrid. My investigations have benefited much from the regular gatherings of the research group. When it was time to write, revise, talk, revise, read and revise my absolute gratitude, as ever, goes to Sabine Scheuring and Anton Nikolotov for being there every step of the way. 


\section{Contents}

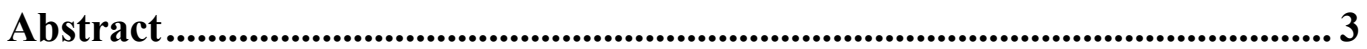

Acknowledgements................................................................................................ 5

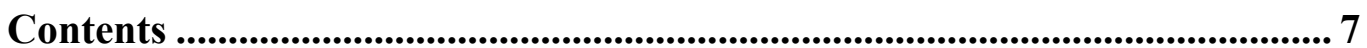

List of Maps ................................................................................................................. 9

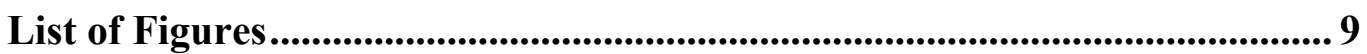

Abbreviations ….............................................................................................................. 10

1. Introduction: Recruiting with Language and Money ............................... 11

1.1 Economies of Deception and Escalation: Panyarring and Dash ........... 17

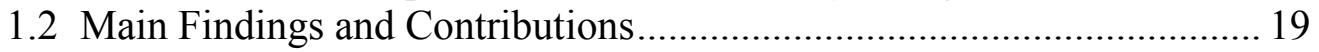

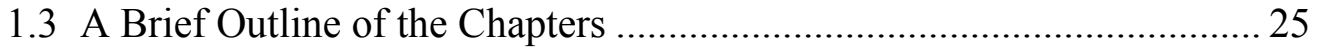

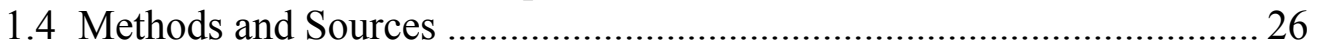

2. Imperial Formations and Atlantic Constellations.................................... 31

2.1 First Contracts, First Recruiters, 1850s-1890s …................................ 34

2.2 Tout Preludes: Fernandinos and Agudas, 1880s-1910s........................ 43

2.3 Despots Displace Touts in Liberia, 1890s-1920s ................................ 52

2.4 Touts and Despot Supplant Each Other in Rio Muni, 1900-1930s ........ 57

2.5 Figures in West and Southern African Colonial History ....................... 70

3. Touts and Despots Combine: Panya or the Bonding of Labour with Language 76

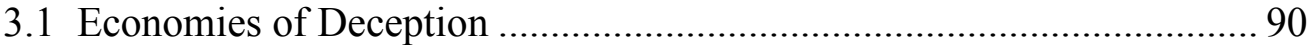

3.2 Voices from the Archives................................................................... 100

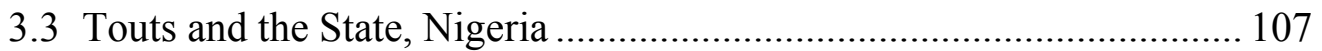

3.4 Language and Violence, Fernando Pó................................................. 114

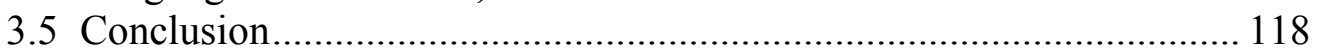

4. Touts vs. Despots: Dash or the Contradiction of Bonding Labour with Money

4.1 Assembling an Economic Coup in 1952 .......................................... 136

4.2 Dash Renegotiations: Gancho-Touts ............................................. 147

4.3 Dash Life: Smugglers, Prostitutes and Planters .................................. 153

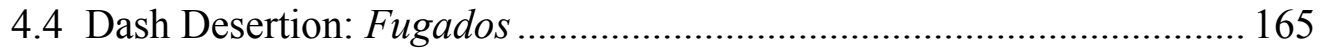

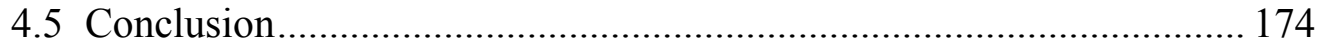

5. It's Time to Talk about the Contract........................................................ 177

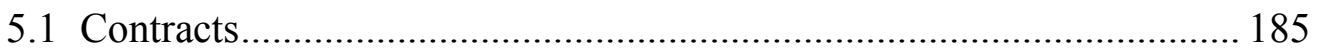




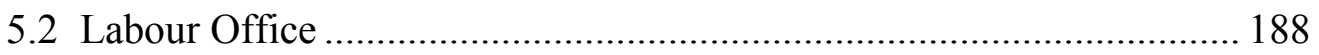

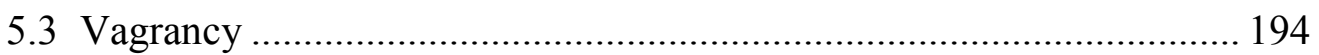

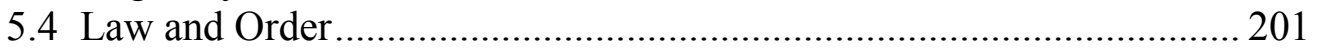

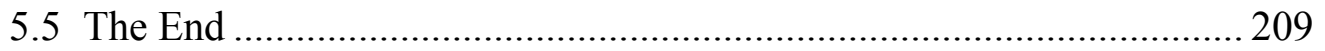

6. Conclusion: Implications for the 'Spectrum' .........................................2 213

6.1 The Middle and End of the Spectrum ............................................... 217

6.2 Main Results: Touts Blur the Line with Panya and Dash.................... 220

6.3 Wider Conclusions: Trafficking and People Smuggling Today ........... 225

Archives and Primary Sources ...................................................................... 229

Bibliography ............................................................................................................... 251

Appendix: Graphs and Tables .................................................................. 308

Glossary .................................................................................................................... 310 


\section{List of Maps}

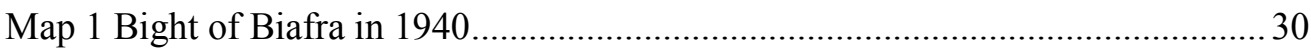

Map 2 Fernandino plantations on the east coast, 1901 ........................................... 44

Map 3 Composite of Rio Muni and south-west Cameroon, early 20th century .........58

Map 4 Social groupings in south-eastern Nigeria, boundaries approximate ............. 89

Map 5 Cross River in 1842 with old and new place-names superimposed ............... 90

Map 6 Santa Isabel, 1950s; each dot is one factoria ............................................. 155

Map 7 An own addendum-'Gulf of Guinea 1867-1975'—to Northrup's map .... 184

\section{List of Figures}

Figure 1 Cayucos or canoes arriving in Santa Isabel, 1940s ..................................... 15

Figure 2 Tout-despot assemblages; in and through the contract ............................. 26

Figure 3 Smugglers arriving in Santa Isabel, 1944.................................................. 34

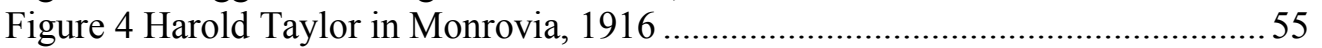

Figure 5 Ekpe Eyo's letter, 2 September 1938 ..................................................... 101

Figure 6 Aerial view looking south from Calabar; Oron top right, July 2012 ......... 106

Figure 7 Aerial view of Santa Isabel with arrows to sites ...................................... 112

Figure 8 Oron Town, beyond the edge of the colonial pier ................................... 113

Figure 9 "The Kidnapped labourers referred to in my Report at Livani Farm" ...... 117

Figure 10 The Curador, Sebastian Llompart Aulet, 1955 ..................................... 137

Figure 11 Peter Pan's 'Brutal Island' in Sunday Times ............................................ 146

Figure 12 Nigerian braceros in plantation 'Casa Mallo', 1950s ........................... 147

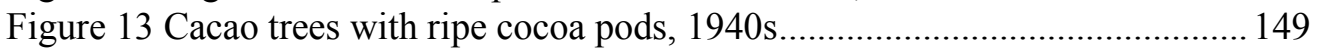

Figure 14 Factorias in Santa Isabel, Francoist period........................................... 154

Figure 15 Campo Yaounde, Francoist period ....................................................... 158

Figure 16 Imported wine barrels at Santa Isabel harbour, 1930s ........................... 160

Figure 17 Fincas or plantations, twentieth century ............................................... 191

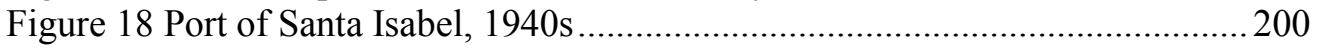




\section{Abbreviations}

Administrative organs and positions; sorted hierarchically; used in footnotes.

ILO International Labour Organization, Geneva.

DGMC Colonial Office, Madrid (Ministerio de Ultramar, 1863-1899; Sección Colonial del Ministerio de Estado, 1901-1925; Dirección General de Marruecos y Colonias within Presidencia del Gobierno, 1925-1931; Inspección General de Colonias within Presidencia del Consejo de Ministros, 1931-1935; Suppressed, 1934-1936; Servicio Nacional de Marruecos y Colonias within Vicepresidencia del Gobierno, 1938-1939; Dirección General de Marruecos y Colonias within Ministerio de Asuntos Exteriores, 1939-1942; Dirección General de Marruecos y Colonias within Presidencia del Gobierno, 1942-1956; Dirección General de Plazas y Provincias Africanas within Presidencia del Gobierno, 1956-1969).

GG Governor, Santa Isabel (Gobernador General de Fernando Póo y sus Dependencias, 1859-1885; Gobernador General de los Territorios Españoles del Golfo de Guinea, 18851956; Gobernador General de la Provincia del Golfo de Guinea then Región Occidental Española then Region Ecuatorial, 1956-1963; Comisario General de la Region Ecuatorial, 1963-1968).

SubGG Lieutenant Governor, Bata (Subgobernador General de la Guinea Continental; subdivided between Bata y Elobey, 1909-1935, then unified in Bata. The small islands Annobón, Corisco, Elobey Grande y Elobey Chico sometimes had their own Subgobernadores).

Curaduría Labour Office, Santa Isabel (Curaduría Colonial, 1901-1941; Delegación de Trabajo, 1941-1968; The Labour Officer was called El Curador).

Cámara Agricultural Chambers of Commerce, Santa Isabel (Cámara Agrícola de Fernando Póo, 1906-1976. Exclusive and sole planters lobby; the planters in Río Muni founded the less influential Cámara Agricola y Forestal de la Guinea Continental in 1928 which will be referenced as Cámara Bata. In 1936 the timber merchants founded their own lobby, the Sindicato Maderero).

AT District Offices in Spanish Guinea (Administración Territorial in each Demarcación; Fernando Pó was divided into Santa Isabel, San Carlos and Concepción [-1938], then Este and Oeste [1938-] and Rio Muni into Bata, Río Benito, Kogo, Niefang, Mikomeseng, Bimbiles, Evinayong, Acurenam, Nsork, Ebibeyin, and Mongomo [-1938]; then in 1942 some districts are redrawn and place-names are slightly changed into more Spanish sounding ones such as Sevilla de Niefang).

Policía Police, Santa Isabel (Comisario Jefe de la Policía Gubernativa de Santa Isabel); Police duties were also taken over by the Guardia Colonial (Guardia Territorial, 1959-1968).

CO; FO Colonial Office, London; Foreign Office, London.

British VC British Vice Consul, Santa Isabel; (Between 1912-1940 the position was honorary and run part-time by a resident merchant from one of the various British firms on the island).

British LO British Labour Officer, Santa Isabel; (Post was established between 1941-1945 then duties were subsumed into the position of Vice Consul, with most of the work being done by uncredited Assistant Labour Officers who were always Nigerian).

DO

District Officer of Nigerian districts or divisions; (The most relevant Eastern Provinces were Calabar and Owerri, each was headed by the so-called "Resident". Provinces were in turn subdivided into districts or divisions). 


\section{Introduction: Recruiting with Language and Money}

My dissertation is about labour recruiters in Spain's last plantation colony, the island of Fernando Pó in the Gulf of Guinea. I have tried to find and follow the recruiters who after the transatlantic slave trade brought labourers into imperial plantations: this time to plantations run on indenture and this time to plantations that were right off the West African coast. To get labourers onto the two colonial plantation islands in the Gulf of Guinea, Fernando Pó and São Tomé, William Clarence-Smith says, "every formula was tried. Slavery, indentured labor, forced labor, [debt and] tax-induced migration, and free-wage labour". ${ }^{1}$ These formulae were tried in no particular order. The arc of Spanish imperial rule in the Gulf of Guinea was not an incremental new dawn; there were few signs of "progress". Unlike the colonial labour "ideologies" of the post-war British and French empires in Africa, the Spanish colonization of the territories in the Gulf of Guinea did not seek to discard the past and install step-wise or mission-oriented reforms where "free" labour was held to be a "basic test of the responsible colonizer."2 Fernando Pó is more than an exception to the vision that the colonial century in African history contains the arc of a colonially-imposed breakthrough from unfree to free labour. Rather, it is a peculiar place from whose perspectives and experiences one can partially rethink the internal and global operations of the entire arc.

The framing of labour history along the broad "unfree" to "free" timeline provided by imperial rule relays a notion that if "unfree" relations subsisted into the second half of the twentieth century, then these must have been the result of a remnant or of the resurgence of a barely superseded pre-colonial time. Fernando Pó reveals that the "transition" was not "failed", that it was not only marked by complexity and incompletion. In particular, it is Fernando Pó's recruiters who reveal that the

\footnotetext{
${ }^{1}$ William G. Clarence-Smith, 'Cocoa Plantations and Coerced Labor in the Gulf of Guinea, 1870 1914', in Breaking the Chains: Breaking the Chains: Slavery, Bondage and Emancipation in Africa and Asia, ed. Martin A. Klein (Madison: University of Wisconsin Press, 1993), 150-70, 153.

${ }^{2}$ Frederick Cooper, Decolonization and African Society: The Labor Question in French and British Africa (Cambridge: Cambridge University Press, 1996), 23.
} 
"transition" could go into a variety of sanctioned and unsanctioned directions and end up with novel and unexpected "free" and "unfree" forms. Fernando Pó adds a series of crystallizations and co-existing shades that shifts the usual narratives of postabolition imperial labour relations and the process of colonization in Africa. To reveal these various shifts, I focus on the recruiters who have rarely been the focus of a consistent and full inquiry. ${ }^{3}$ This is why I have decided to inquire into what the recruiters actually did, who they were, where they organized their deployments, which steps were taken, what changed hands, what information and misinformation did they channel, who saw whom in which light.

In African - but also global-labour history few have offered "a rare glimpse into the actual mechanics of the labour market". In the history of colonial migration this glimpse tends to open up into a space that was almost wholly made up by "intermediaries and interlopers" who emerged from the "struggle for labour". 4 Recruiters, in their own voice only make rare guest appearances in the colonial archive, even less than the subaltern labourers themselves. There are only a handful of first-hand accounts of the recruiters themselves, whose reasoning or justification for their own actions, their relationship to the colonial state and to the workers whom they recruited, is as ambivalent as the way I will portray them in this dissertation. Studying the recruiters involved in the mobilities around indentured labour is difficult, not because of a lack of sources - as sources about recruiters are abundantbut because of our own conceptualization of the figure of the recruiter; a legacy of the top-down colonial sources.

Recruiters orchestrated the obscure groundwork of the so-called "Labour Question"an endemic obsession pervading the African colonial archive but also many other

${ }^{3}$ Giovanni Arrighi, 'Labour Supplies in Historical Perspective: A Study of the Proletarianization of the African Peasantry in Rhodesia', Journal of Development Studies 6, 3 (1970): 197-234, 209. See also Alan Jeeves and Jonathan Crush, eds. White Farms, Black Labor: The State and Agrarian Change in Southern Africa, 1910-50 (Portsmouth: Heinemann, 1997).

${ }^{4}$ Martin J. Murray, "'Blackbirding" at "Crooks" Corner: Illicit Labour Recruiting in the Northeastern Transvaal, 1910-1940', Journal of Southern African Studies 21 (1995): 373-97, 376; For detailed exceptions Alan Jeeves, Migrant Labour in South Africa's Mining Economy: The Struggle for the Gold Mines' Labour Supply, 1890-1920 (Kingston: Queen's Press, 1985), 3-34, 239-64; and Andrew MacDonald, 'Colonial Trespassers in the Making of South Africa's International Borders 1900 to C. 1950’ (PhD Thesis, Cambridge University, 2012), 242-90. 
capitalist archives elsewhere. ${ }^{5}$ In Fernando Pó the shortage and compulsive recruitment of labour was unusually pronounced. "There exist here the problema de braceros. It is said 'we lack braceros' and this is the principal and almost sole obsession of the planters." Apart from the rhythms and discipline of plantation cultivation, "recruitment is the principal activity of plantation businesses". " 6 e la recluta cuenta se y no se acaba"-_once talk of recruitment starts it cannot stop". The sources are unanimous: "Speaking in terms unequivocal and without the slightest fear of contradiction the labour problem in Fernando Poo is of paramount importance." 8 The "so-called problema is principal and decisive", it was said to be the "principalisimo of all colonial politics". "The archive seems to be only about el problema bracero", says the historian Enrique Okenve. ${ }^{10}$

\footnotetext{
${ }^{5}$ Frederick Cooper, 'Work, Class and Empire: An African Historian's Retrospective on E. P. Thompson', Social History 20, 2 (1995): 235-41; Jeff Crisp, 'The Labour Question in the Gold Coast, 1870-1906', in Proletarianisation in the Third World: Studies in the Creation of a Labour Force Under Dependent Capitalism, ed. Barry Munslow and Martin H. J. Finch, (London: Croom Helm, 1984), 1842; The Spanish wording of these "chronic labor shortages" were put in the same terms elsewhere, for example in Guatemala "the planters' persistent cry [was] 'faltan brazos", David McCreery, 'Debt Servitude in Rural Guatemala, 1876-1936', The Hispanic American Historical Review, 63 (1983), 735-59, 739. In relation to colonial Assam, the alarmist-obsession of "scarcity" has be seen as a ploy to impose long-term contracts on imported labourers resulting from the aversion of planters to hire local labour who could demand much higher wages and control their day to day labour. Kaushik Ghosh, 'A Market for Aboriginality: Primitivism and Race Classification in the Indentured Labour Market of Colonial India', in Subaltern Studies X: Writings on South Asian History and Society, ed. Gautam Bhadra, Gyan Prakash, and Susie Tharu (New Delhi: Oxford University Press, 1999), 8-48.
}

${ }^{6}$ Román Perpiñá Grau, De colonización y economía en la Guinea española: investigación, sobre el terreno, de la estructura y sistema de colonización en la Guinea española, con referencia especial a lo económico (Barcelona: Tall. Ibero Americanos, 1945), 118.

${ }^{7}$ Ángel Miguel Pozanco, Guinea mártir: narraciones, notas y comentarios de un condenado a muerte (Barcelona: Colección Actualidad, 1937), 86-87.

${ }^{8}$ Kicks-Dadzie to Resident, Calabar, September 1939, 'Confidential Report: Labour in Fernando Poo', NAE, CALPROF 5/1/195.

${ }^{9}$ Román Perpiñá Grau, 'Mano de obra africana, factor de coste colonial: investigación sobre el peso de los braceros contratados en Fernando Poo', Cuadernos de Estudios Africanos 3 (1947): 127-44, 127.

${ }^{10}$ Enrique Okenve (personal correspondence, 5 July 2014). The “'manpower crisis' obsessively preoccupied colonial officers and settlers alike. [...] In fact, one only needs to look at the colonial archives to realize that, in addition to government personnel, the bulk of the documentation deals with labour matters." Enrique Sang Okenve Martinez, 'Equatorial Guinea 1927-1979: A New African Tradition' (PhD Thesis, London, SOAS, 2007), 174. "[W] hat really preoccupied the colonials was ways of getting cheap labor power into its plantations." Gonzal Sanz Casas, 'Política colonial y organización del trabajo en la isla de Fernando Poo: 1880-1930' (PhD Thesis, Barcelona, Universidad de Barcelona, 1983), 222. The other historians who have done archival work of a social history of 
The problem of labour scarcity and the associated recruitment campaigns is the running theme across Fernando Pó's colonial history. Fernando Pó was West Africa's largest island, and it is one of the most understudied places in African and Atlantic history, even though it generated some of most significant colonial labour migrations. The social history of Equatorial Guinea through the work of Ibrahim Sundiata has paid close attention to the recruiting of labourers during the first three decades of the twentieth century, when a substantial portion, but not the majority of contract workers were brought in by the Liberian state. Spanish scholars have also paid close attention to the destructive and often short-lived despotic recruitment of the indigenous Bubi of the island and of the Fang in Rio Muni. ${ }^{11}$ In this dissertation I briefly detail these and various other formal and informal forms of recruitment in Spanish Guinea and the Gulf of Guinea, from the late 19th century to the 1970s, from Angola to Sierra Leone, from Ghana to Liberia, or rather Sinoe county in Liberia, and then Bata, Niefang, Ebebiyín, Ambam, Woleu-Ntem, in Rio Muni, Cameroon, and Gabon. However, I decided to focus particularly on one sub-set of recruiters, namely the illegal canoegoing Nigerian recruiters who were the principal labour smugglers or suppliers to the islands planters between the 1930s and the 1950s.

labour are Ibrahim Sundiata and Gustau Nerín (see bibliography), and Dolores García Cantús, 'Fernando Poo: una aventura colonial española en el África Occidental, 1778-1900' (PhD Thesis, Universitat de València, 2004), 577, who says the "question of the falta de braceros continued to be the principal obstacle for the full development of agriculture in the colony, and was accompanied by the ever expanded recourse to coercion."

${ }^{11}$ The time frame seems to be accounted for by the fact that until the 1990s the only guide to the Spanish archives was made by the UNESCO, a guide that indexed only items up to the year 1930. Gonzal Sanz Casas, 'Los finqueros y el uso del trabajo forzado en la agricultura colonial de la isla de Fernando Poo', Arxiu d'Etnografia de Catalunya, 3 (1984), 123-36; Dolores García Cantús, 'El trabajo forzado bubi en la colonia española de Fernando Poo, 1891-1912', Between Three Continents: Rethinking Equatorial Guinea on the Fortieth Anniversary of its Independence from Spain, Hofstra University, New York, April 2-4 2009. For authors who have retained this emphasis without looking at the archive, because the archive did not allow for it, see Liniger-Goumaz's spree of overview publications and Clarence-Smith's early articles on Spanish Guinea. For a splendid but overlooked piece of writing, almost the only one that looks at Fang labour in Rio Muni during the Republican and Francoist period in any detail, but also without archive, see Valentin Oyono Sa Abegue, 'L'évolution Des Structures Productives et Sociales de L'économie de La Guinée Equatoriale 1858-1968' (PhD Thesis, Université de Lyon II, 1985). This imbalance has only recently been redressed through the work of Gustau Nerín and soon, through the upcoming publications of Gonzalo Álvarez Chillida. See also Benita Sampedro Vizcaya, 'Rethinking the Archive and the Colonial Library: Equatorial Guinea', Journal of Spanish Cultural Studies 9 (2008): 321-41. 


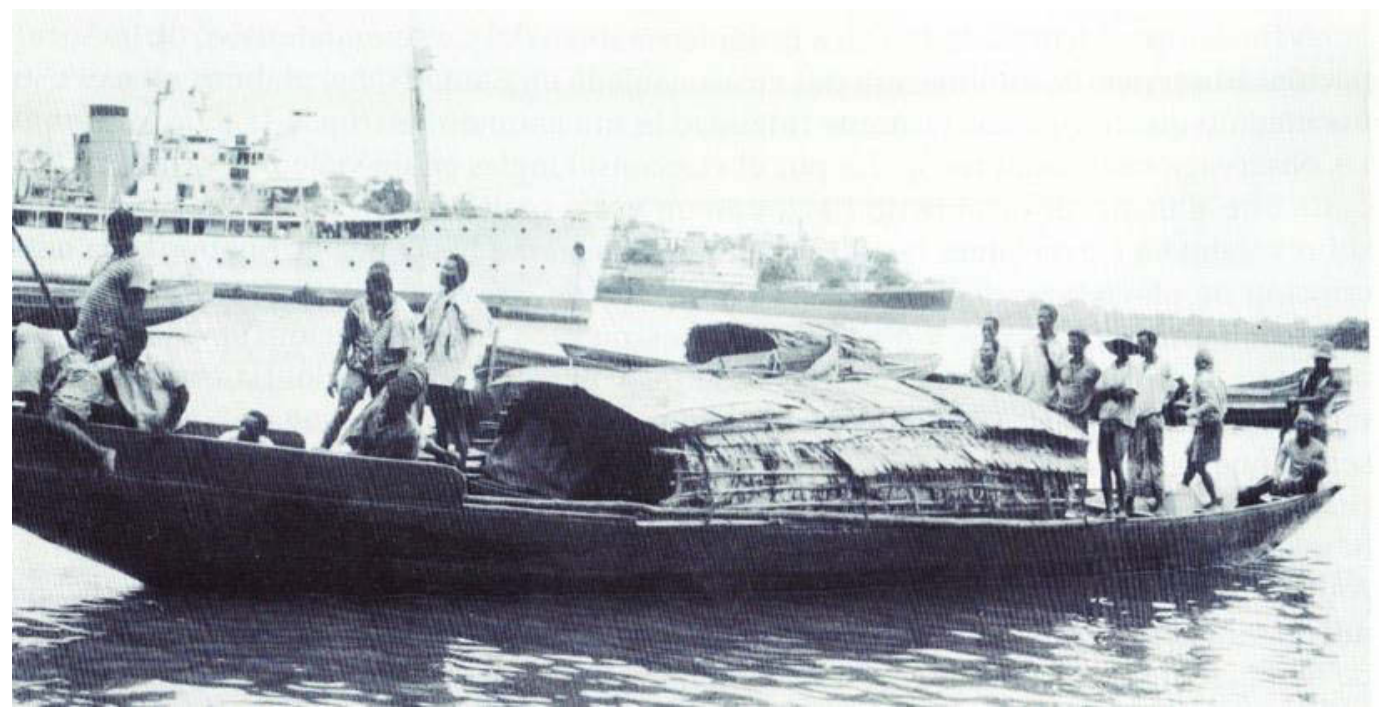

Figure 1 Cayucos or canoes arriving in Santa Isabel, 1940s ${ }^{12}$

Along the Cross River Delta in south-eastern Nigeria, recruiters were drawn from some of the groups who just two generations prior had still been organizing the slave trade. The paradox I had to confront was while they were being described as a type of "new" slave traders they were nothing of the sort. There were never more than fifty to two hundred of these individual recruiters at a time; they could each mobilize dozens of new recruits every year. They did this through different means, sometimes they conducted a type of fraud that essentially amounts to a non-violent kidnapping, other times, more commonly, all that was needed was the false promise of a large wage advance or a well-placed job, whether in Fernando Pó or elsewhere. These recruiters came up with harassing and tempting stories, but their principal way of being effective came from their handling and relaying of wage advances. They tended to continue with ever more elaborate misdirections as to the specifics of the destination. During the first half of the twentieth century this was the only effective mode of sourcing labourers for two- to four-year contracts outside surges within the territory of Spanish Guinea and Liberia of despotic conscription and arrest.

These informal recruiters tended to appear in a modality I describe and theorize as touts. ${ }^{13}$ Recruiter-touts were not licensed, they were not even directly delegated by

\footnotetext{
${ }^{12}$ Caption: "Los cayucos solían llegar a Santa Isabel con viajeros y mercancías procedentes de la costa", in Martínez, Poto Poto, 40.
} 
imperial capital, by employers. Touts often started off penniless-with a few forged papers and a hired canoe at most - and armed themselves only with promises or the capacity to speak about and relay fictitious places and fictitious money. They set off autonomously, inflating language and money, as well as with the indispensable knowhow enabling them to bypass imperial bureaucracies. This skill-set was necessary and generated because the unauthorized emigration to Fernando Pó was being repressed by the British in Nigeria, while in Fernando Pó itself the authorities tried to standardize and lower the recruiter's commissions and the worker's wage advances. In contrast to a well-established line of reasoning in migration studies, the "bulk" of the trajectories of migrant labour around Fernando Pó in the Bight of Biafra, cannot be said to have been "channelled" through an "independent networks of friends, family and villagers". People in these corners of the Gulf of Guinea were also "on the move, flowing into factories, construction projects, mines, plantations, agricultural frontiers, and commercial networks across the globe,"14 and almost all of them were being brought into colonial workplaces by touts.

Theirs was a complicated network with many components, the transport linkages, legacies, individual gangs, canoe-rowers, commissions, forgeries, briberies, and so one; a recruitment "assemblage" 15 that involved thousands of people and objects. An

\footnotetext{
${ }^{13}$ The term "tout" was coined in the so-called "rogues' cant" or "peddler's French" by eighteenthcentury street thieves and meant: "to act as a lookout, spy on". The tout is in a sense the "first job' of the underworld. Tout as a verb, touting, acquired its principal meaning: 'to look out for jobs, votes, customers, etc., to try to get them' by the early 1730 s, and only with the consumer revolution in the 1920s does a new meaning of embellishment appear: 'praise highly in an attempt to sell'. 'Tout', etymonline.com.
}

${ }^{14}$ Adam Mckeown, 'Global Migration, 1846-1940', Journal of World History 15, 2 (2004), 155-189, 167. See also Philip D. Curtin, Why People Move: Migration in African History (Waco: Markham Press Fund, 1995); Dennis D. Cordell, Joel W. Gregory, and Victor Piché, Hoe and Wage: A Social History of a Circular Migration System in West Africa (Boulder: Westview Press, 1996).

${ }^{15}$ In archaeology, assemblage is default term for a group of artefacts that are found with some sort of association to each other. An assemblage is made up linkages, it becomes a solidified arrangement of plural objects that come together through relations and are propelled in their combination. Even though assemblages are composed of heterogeneous qualities and are always in formation, they achieve a consistency, a hardened direction, an emergent unity; but these can also be extraordinarily unstable. An automobile is for example an assemblage: each component can have its own heterogeneous history and design. The wheel dates back millennia, rubber is a much latter and bloodier attachment, motors can also be composed and decomposed, and each part has its own history in autonomous trajectories of experimentation and standardization, and the like; properties of velocity or drag, or the institutional regulations and licenses of roadways, that are also part of the assemblage. This concept of assemblage comes from a French post-structuralist tradition, via Deleuze and Guattari, though others have done 
investigation into this type of "underground" of recruitment has rarely been achieved in colonial African history so I consider this to be my principal empirical contribution. I also consider my dissertation a West African contribution to Global Labour History because recruiters, and especially their techniques, have only been examined in detail in post-colonial Peru, the Bay of Bengal and parts of South Africa.

\subsection{Economies of Deception and Escalation: Panyarring and Dash}

The element of novelty in my dissertation is that I analyze and conceptualize the two primary techniques of touts at length. These two techniques are what I call sublated panyarring and dash-peonage, which I explore in the two core chapters of this dissertation, the panya chapter and the dash chapter.

By panyarring I refer to the 20th century south-eastern Nigerian sense of the word as "removal to the unknown"- as Ugo Nwokeji says his Igbo informants remembering a type of enslavement under early colonial rule defined it. They directly associated panyarring with Panya, and panya meant España or Fernando Pó in pidgin. This panya panyarring operated through an inversion of the kidnapping techniques of the Atlantic slave trade. Even though touts were often labelled slave traders, they were of course not armed. They did not use chains, they did not "remove people to the unknown" through the political violence of raids or the sanctioned violence of creditors. Touts did not induct you into capitalist labour systems through the conduits of slaving violence but rather through language alone, through a quasi-kidnapping arising from misinformation as to the destination or the type of work. Many Nigerians, tens of thousands, ended up forcibly contracted to Fernando Pó's planters and considered their temporary fate to be a type of slavery-which in effect it was, just for a delimited period. This operation only worked because once on the island signing a contract was obligatory.

By dash I mean the dash in its elementary structure, what Jane Guyer calls an “ancillary to an exchange”. Dash in Fernando Pó's pichinglis as in many of the 
Pidgins spoken on the West African coast meant this "gift-money" that comes before but, like a supplement, is constitutive of the exchange. ${ }^{16}$ The dash was and is used in precolonial and also postcolonial contexts to facilitate, mediate and stabilize very different types of exchanges, such as bribes, obligatory commissions and even informal wage advances. The dash that emerged in relation to Fernando Pó's contract engendered a type of peonage. Increasingly from the early 1940s on the majority of workers stayed on Fernando Pó for a second contract, because almost all of the promised "dash" money of their earnings from the first contract went to the recruiter as their commission. This time the re-contracted workers demanded their own very substantial dash before they entered a further contract. In this constellation workers gathered around touts on the island as they played a prime role in renegotiating these high informal advances. Workers did not see this as a gift or a bonus but as a wage advance because for them it was a way to effectively increase total wages for a fixed contract, or even to be paid their wages at all as many planters went bankrupt or withheld and deducted official wages. Planters would often try to justify the forced recontracting of their labourers for a third contract with reference to this large dash even though labourers wanted to leave or hire themselves elsewhere, usually for a higher dash. The dash quickly exceeded the formal official wages, and so what the planters were doing is deploying the moral arguments of debt-bondage to try to extend their workers' contracts. At the same time this rising dash that was being pushed up by workers led to ever higher rates of desertions - the logistics and negotiations for which were all arranged by touts. These desertions were aimed at the higher dashes paid out by other planters, particularly the ones who had to now provide better working conditions to attract workers on their second or third contract; some

\footnotetext{
${ }^{16}$ Jane Guyer, Marginal Gains: Monetary Transactions in Atlantic Africa (Chicago: University of Chicago Press, 2004), 20, 59. For a theorization of the combination of a stable price and the "dash" as a negotiated component, an amount to be named, assessed, inspected and deemed appropriate see Jane Guyer, 'Comparisons and Equivalencies in Africa and Melanesia', in Money and Modernity: State and Local Currencies in Melanesia, ed. David Akin and Joel Robbins (Pittsburgh: University of Pittsburgh Press, 1999), 232-46, 237. The word "dash" is derived from the sixteenth century Portuguese doação, meaning gifting or giving money or goods. Paul Christophersen, 'A Note on the Words Dash and Ju-Ju in West African English', in Perspectives on Black English, ed. Joey Lee Dillard (Berlin: Walter de Gruyter, 1975), 212-15, 213. For the pre-colonial and more contemporary forms of the dash see my blogpost 'Dash: the gift of West African commercial life, etymology and a brief genealogy', find through search engine.
} 
even had 12 contracts in one go because they kept deserting and receiving more dashes.

Panya and dash; my dissertation tries to understand and trace the transformation of these two African or commercial Afro-European practices in Fernando Pó. In the recruitment economies of the mid-twentieth-century Bight of Biafra panya and dash were reconfigured by the creative actions and reinterpretations of African touts and workers. A history of these practices cannot be written as simple economic exchange; rather, they represent two parallel and asymmetrical modalities where notions derived from the world of exchange do not add up, namely: theft and gifts. To understand the operations of panya panyarring and dash-peonaje in the recruitment of contract labour in Fernando Pó one cannot use conventional political economy of wage labour or orthodox theories of the contract.

I do not argue that pre-colonial practices of kidnapping and gift-giving, which had been integral to the slave trade on the West African coast, continued in the colonial period but that panyarring and dash were reinvented and readapted under colonial conditions, specifically in relation to the Spanish imperial labour contract. A transformation had taken place. Following this transformation from the precolonial to colonial period is my principal conceptual contribution to African history and even to global history. To global history because I take these two concept-practices that Nigerian touts and workers generated, and then read other sources and historical periods through their lens. Dissecting panya can explain why violence is sometimes seemingly absent in the world of unfree post-slaving recruitment; dash reveals the contradictory role of money in debt bondage. These two modes, quasi-kidnapping and quasi-debt-bondage, whose dynamics emerged through the bottom-up, have not received systematic and comparative attention in African or global labour history.

\subsection{Main Findings and Contributions}

By tracing the recruiting patterns in Fernando Pó and across the Gulf of Guinea, and even across islands and enclaves of indenture more generally, I came to two principal findings: the technique of panya contains an intrinsic spatial movement of recruiters and dash contains a similar dynamism that takes the form of an in situ escalation. 
Both of these techniques, as I posit throughout the core chapters and elaborate in the final two chapters, were only made possible by the existence of the contract. I characterize the contract as "despotic" because it was the imperial violence exercised through the contract on the island that underpinned these two techniques. This is why I talk about a tout-despot recruiting assemblage that included the contract as a necessary component, without which exchange and circulation could not take off.

The first finding emerges from the fact that touts did not and could not operate within a fixed hinterland: they unleashed themselves in waves, and operated necessarily on a patchwork of ever-new fringes, constantly pursuing new victims to disappoint or impressing well-versed hopefuls with the promise of ever-larger sums of advanced wage-money. The second finding, the escalation of dash, in turn, results from a lack of hinterland, and hence a lack of new labour. With panya and dash as recruiting technique there was no cycle, no circular migration, no equilibrium. Braceros who had been to panya left after two years, after their first contract, or because of the dash they stayed on for a further two or four years. They then left, so a new generation of workers had to fill the ranks, but these came always from somewhere else, where touts would improvise the same techniques and add onto them ever more elaborate fabrications and false guarantors. There was a constant drift of recruiters across the entirety of the Gulf of Guinea, from west to south from the 1880s on, and internally in Nigeria itself, where by the late 1940s only a large handful of "illegal recruiters [were] still operating in the northern half" of the Eastern Provinces "where the people are more ignorant and where they can get victims by promising them work in Port Harcourt or Calabar". ${ }^{17}$

The shade of the first pattern grew out of the essential component of duplicity in the touts' toolkit. The slave trade conceptually contaminated its supposed opposite-free migrant contract labour - through the revelations and scandalization of typical and ongoing recruitment techniques which are referred to in the revisionist literature on indentured labour as the "deception argument", as Marina Carter says sceptically in relation to arkatis or the touts in the Bay of Bengal who recruited indentured labour

\footnotetext{
${ }^{17}$ British VC and LO (Spencer-Cooke) to Commissioner of Labour, Lagos, 26 June 1950, 'Labour Report for the period 1st of April to the 30th of June 1950', TNA, CO 554/169/1.
} 
for Mauritius. ${ }^{18}$ A generation of historians in the 1980s known by detractors as the "Modernization School, sometimes also indicated as the Imperialist or Colonial Group" turned the fact that "most indentured migrants left their homes voluntarily" with "hopes of better conditions and opportunities" into a realization of volition and desire in migration, an expression of will. ${ }^{19}$ Such accounts of indentured labour have continued to circumscribe the possibility that indenture was "founded on duplicity". While aware of the "persisting evidence of fraud in indentured recruitment", many authors turn "specific" instances of deception usually "related to destination" into a minor and incidental detail in the larger scheme of self-initiated migration for selfimprovement along capitalist lines. ${ }^{20}$

Nevertheless, revisionist scholars who are rightly cautious and weary of representing indentured migration within the rhetoric of unfreedom, all vindicate the foundational insight of the "Tinkerian paradigm", as Tinker himself says in his 1974 book on indenture as A New System of Slavery, "fraudulent statements [and] false pretences"” were constitutive of the world of recruiters who mastered the art of presenting a "picture of what was to come which was often distant from reality". ${ }^{21}$ In midtwentieth century Fernando Pó, whether those who experienced their displacement as a "willing" response to a transparent offer or whether they were "drawn to a new land by the better-than-factual stories", all went side by side on the same canoes

\footnotetext{
${ }^{18}$ Marina Carter, 'Strategies of Labour Mobilisation in Colonial India: The Recruitment of Indentured Workers for Mauritius', Journal of Peasant Studies 19, 3/4 (1992): 229-45, 230.

${ }^{19}$ Paul E. Baak, 'About Enslaved Ex-Slaves, Uncaptured Contract Coolies and Unfreed Freedmen: Some Notes about "Free" and "Unfree" Labour in the Context of Plantation Development in Southwest India, Early Sixteenth Century-Mid 1990s', Modern Asian Studies 33, 1 (1999): 121-57, 125; David Northrup, Indentured Labor in the Age of Imperialism, 1834-1922 (Cambridge: Cambridge University Press, 1995), 7; see also David Eltis, The Rise of African Slavery in the Americas (Cambridge: Cambridge University Press, 2000), 200; Verene A. Shepherd, "The Other Middle Passage?" Nineteenth-Century Bonded Labour Migration and the Legacy of the Slavery Debate in the BritishColonized Caribbean', in Working Slavery, Pricing Freedom: Perspectives from the Caribbean, Africa and the African Diaspora, ed. Verene A. Shepherd (New York: Palgrave, 2002), 343-377.

${ }^{20}$ Carter, 'Strategies of Labour Mobilisation in Colonial India', 238.

${ }^{21}$ Hugh Tinker, A New System of Slavery: The Export of Indian Labour Overseas, 1830-1920 (London: Oxford University Press, 1974), 116, 124; see Richard B. Allen, 'Re-Conceptualizing the "New System of Slavery", Man In India 92 (2012): 225-45.
} 
"smuggled across the waters in the Bight of Biafra."22 In Fernando Pó the dynamic of deception had to be more accentuated because the island had a consistently terrible reputation, so that after braceros returned to their home regions a new generation of workers did not follow in their footsteps, but had to be sought out from somewhere else. Only because of this constant drift of touts internally in Nigeria and previously across the entirety Gulf of Guinea, could panya keep working.

Touts single-handedly recruited well over 100,000 people into Fernando Pó, yet they also operated on the island by redirecting the braceros who were already on the island or who were being brought in through channels set up by various imperial states and independent republics. This intervention accounts for the movement of another several hundred thousand people who found themselves between contracts on the island. They could travel hundreds, even thousands of kilometres on foot, on trucks, on steamers or, principally, on canoes or they could stay put on the island and still arrange for vast reconfigurations.

The second pattern emerges from the dash. In a first round, some touts even promised that dash already, but they simply kept this dash as their own commission. During the second round of contracts the dash mostly landed in the pockets of labourers themselves. The dash was always on the increase, being escalated, because planters forked out ever higher ancillary money-wages for already experienced labourers. By the early 1950s this had led to a type of spiral of rising dashes and desertions. This dynamic of the dash was also accentuated in Fernando Pó because, first, smuggling was being effectively repressed by both the British and Spanish colonial state in the late 1940s, and so labour scarcity was reaching another one of its many peaks; and second, for those who had previously been smuggled onto the island there was no repatriation agreements as was common in more formally arranged indentured labour movements, and so many stayed on for a further contract. The dash represented a very considerable sum of money, which was the principal reason why people remained for a further two to six years.

\footnotetext{
${ }^{22}$ David Aworawo, 'Decisive Thaw: The Changing Pattern of Relations between Nigeria and Equatorial Guinea, 1980-2005', Journal of International and Global Studies 1, 2 (2010): 89-109, 92.
} 
The dynamics of illegal and informal recruitment shift in the late 1950s when almost all new recruits were supplied and regulated by the British and later the Nigerian state through an indentured labour treaty. The 1942 "treaty" permitted an association of Spanish planters to pay licensed recruiters small commissions, to construct a large depot in a converted military barracks in Calabar and to send a dedicated steamships to make bi-monthly pick-ups. Cumulatively almost 200,000 workers, plus many tens of thousands of family members, passed through this channel. ${ }^{23}$ British colonial topdown schemes offered single channels of supervised declarations of consent and reduced advances to keep total wages low and sometimes avoid the charge of debt bondage. In the 1960s most braceros had come through the treaty, which was a different but related tout-despot assemblage, as licensed recruiters were only allowed to hand out flyers in Nigeria and they were not allowed to mediate dashes. However touts were also there upstream and downstream, such as when they aided the desertion, at times of up to $30 \%$, of new treaty labourers after they arrived on the island on steamers instead of canoes.

The most intense phase for the dynamics of panya and dash in the Bight of Biafra was between the 1930s until the 1950s. Both dynamics reconfigured or undone by the high numbers, up to 15,000 new workers a year, coming through the labour treaty which finally met the labour demands of the island's planters. For the final decade of colonial rule it was through this scheme "in Nigeria through which we [the Spanish colonial administration] have been able to finally somewhat resolve the problema laboral de Guinea". ${ }^{24}$ While the treaty came towards the end of the history of

\footnotetext{
${ }^{23}$ There were definitely 103,881 new recruits brought in through the treaty in the first twenty years of its operation (1943-1962). Comisión para el Desarrollo Económico de Fernando Poo y Rio Muni, 'Plan de desarrollo económico de la Guinea Ecuatorial: 1964-1967' (Madrid: Presidencia del Gobierno, 1963), Anexo 10. No one has quantified 1962 to 1968, or beyond to 1975 . The revised 1963 Treaty with the Nigerian state, doubled the length of the minimum contract to three years (and four and half in total). A reliable figure for 1964, says that under the treaty some "40,000 Nigerians" were under contract in Fernando Pó, in addition to " 10,000 " in Rio Muni, evidently true if not an underestimate as there was an unprecedented spike in production in 1967 of 37,000 tons of cacao, almost double that of the late 1940s. United States Department of Labor, Labor Digests on Countries in Africa (Washington: Bureau of Labor Statistics, 1966), xxxiii.
}

${ }^{24}$ MAE, 10 March 1962, 'Desarrollo de la economía en Fernando Poo', AGA, C-81/13039, E-392. "These braceros are indispensable, production would plummet without them". In 1960 there were about 15,000 or so Nigerian resident traders, smugglers, self-employed, and so-called libres or "free" or non-treaty workers on local contracts, while some 32,000 (plus 15,000 family members) were “indentured treaty labourers". British Consul, Yaounde, 4 May 1961, 'Despatch No.46', TNA, CO 
recruitment in the Bight of Biafra, it was touts who paved the way; they were an extraordinarily persistent and creative force, albeit one composed of and deploying many.

Because of the structure of the Spanish archive itself-minimal and partial inventories, and even the absence of catalogues for whole collections and entire decades - about 97\% of the Spanish colonial archives of Guinea has remained silent. Because of the difficult state in which the archive lies, a serious oversight has occurred in the historiography. There are no academic publications based on archival research in Spain, Equatorial Guinea, and Nigeria on the migrants who already from the 1930s on, and for the next half century, constituted, by far, the majority of the population of Fernando Pó. Even amongst the regional specialists, there is often not an awareness that this was one of the largest inter-colonial African labour migrations, and certainly the largest that went under the official banner of what the British in Nigeria were still calling 'indenture'. Most facets of life under colonial rule have not only been under researched, but have been completely left out of the picture-there is only one line on the matter in the Cambridge History of Africa: "The main source of labour came to be Ibo smuggled in African canoes from Nigeria. The British rather reluctantly made this current of labour migration legal in 1942, in order to control it." 25 As I will show through new empirical material, the establishment of legal recruitment through the "treaty" took until the late 1950s to consolidate itself, between the 1930s and the 1950s the main source of labour was being recruited by touts.

554/2502. A new and inexperienced Governor, fresh off the boat, gives an underestimate of 40,233 Nigerians in 1960 by citing unreliable census and labour statistics of registered workers. GG (Núñez), 17 March 1962, AGA, C-81/11846; see also Alicia Campos Serrano, De colonia a estado: Guinea Ecuatorial, 1955-1968 (Madrid: Centro de Estudios Políticos y Constitucionales, 2002), 171.

${ }^{25}$ William G. Clarence-Smith, 'Spanish Equatorial Guinea, 1898-1940', in The Cambridge History of Africa: From 1905 to 1940, ed. Arthur D. Roberts et al. (Cambridge: Cambridge University Press, 1986), 540. In the subsequent volume when the complete shift to Nigerian labour occurs in the late 1930s, Equatorial Guinea appear as an Appendix to Basil Davidson chapter on Portuguese Africa, and less than a half a line mentions Nigerian "contract labourers". Basil Davidson, "Appendix Equatorial Guinea, c.1940 to 1975', in The Cambridge History of Africa: From c. 1940 to c. 1975, ed. Michael Crowder (Cambridge University Press, 1984), 806-11, 807. The only detailed treatment of the matter is Akinjide Osuntokun, Equatorial Guinea Nigerian Relations: The Diplomacy of Labour (Lagos: Oxford University Press, 1978), 38-42, a brief study which relies solely on the archive in London. See also Max Liniger-Goumaz, La Guinée Équatoriale: Un pays méconnu (Paris: L'Harmattan, 1979), 361-2. 
As they were usually in it for the money — charging commission for creating a moneydebt through institutionalized bondage-when touts involved themselves in recruitment they were clearly the delayed underside of impersonal currencies within an already imperial horizon. Touts found a quasi-autonomous and informal niche in empire. They ventured into the hinterlands as semi-familiar self-imposed sojourners or insinuated themselves onto already busy side-walks to relocate people into labourhungry plantation patios. They carved out for themselves a slice of profits gained through the labour market that they were themselves generating. In their own time and on their own terms they became the self-organized tools of commercial conquest and capitalist production. They did this with negotiation-usually involving the relaying of advance payment of wages and many other speculative exercises, but unlike despots, without coercion. Despots have a lot of baggage, both in political theory and because of the registries they clutched and the uniforms and heavy weaponry they carried, that is why I laid most of my empirical and conceptual focus on touts.

\subsection{A Brief Outline of the Chapters}

The dissertation follows Fernando Pó recruiters wherever they went, their trials, obstacles and techniques. The two key chapters of the dissertation, 3 and 4, the panya and dash chapters, are framed by one ancillary and one supplementary chapter which provide an exploration of similar earlier techniques of touts in the Gulf of Guinea and a contextualization of how the Nigeria-connection was made possible by the legislative conditions on Fernando Pó. In chapter 2, I outline the previous recruiting assemblages in Fernando Pó's plantation history. In chapter 5, I unpack the component of contract and vagrancy laws that underpinned both panya panyarring and dash-peonage. The core chapters, 3 and 4, consist of an entirely untapped range of primary sources. This wholly new empirical ground starts from Biafra proper, Igboland, to the transit point of Calabar and onto Fernando Pó. Each of these chapters has its own empirical trajectory; chapter 3 involves hooks between the mid-twentieth century Cross River delta and the transformation of an early technique of the indentured labour and even slave trade; chapter 4 places the flight and leverage of the dash that peaked on the island in the 1950s into a constellation of shared drifts across 
various islands and enclaves of indenture in global history. In chapter 6, the conclusion, I turn to the conceptual consequences of recruiters for the "free-unfree" labour spectrum in Global Labour History.

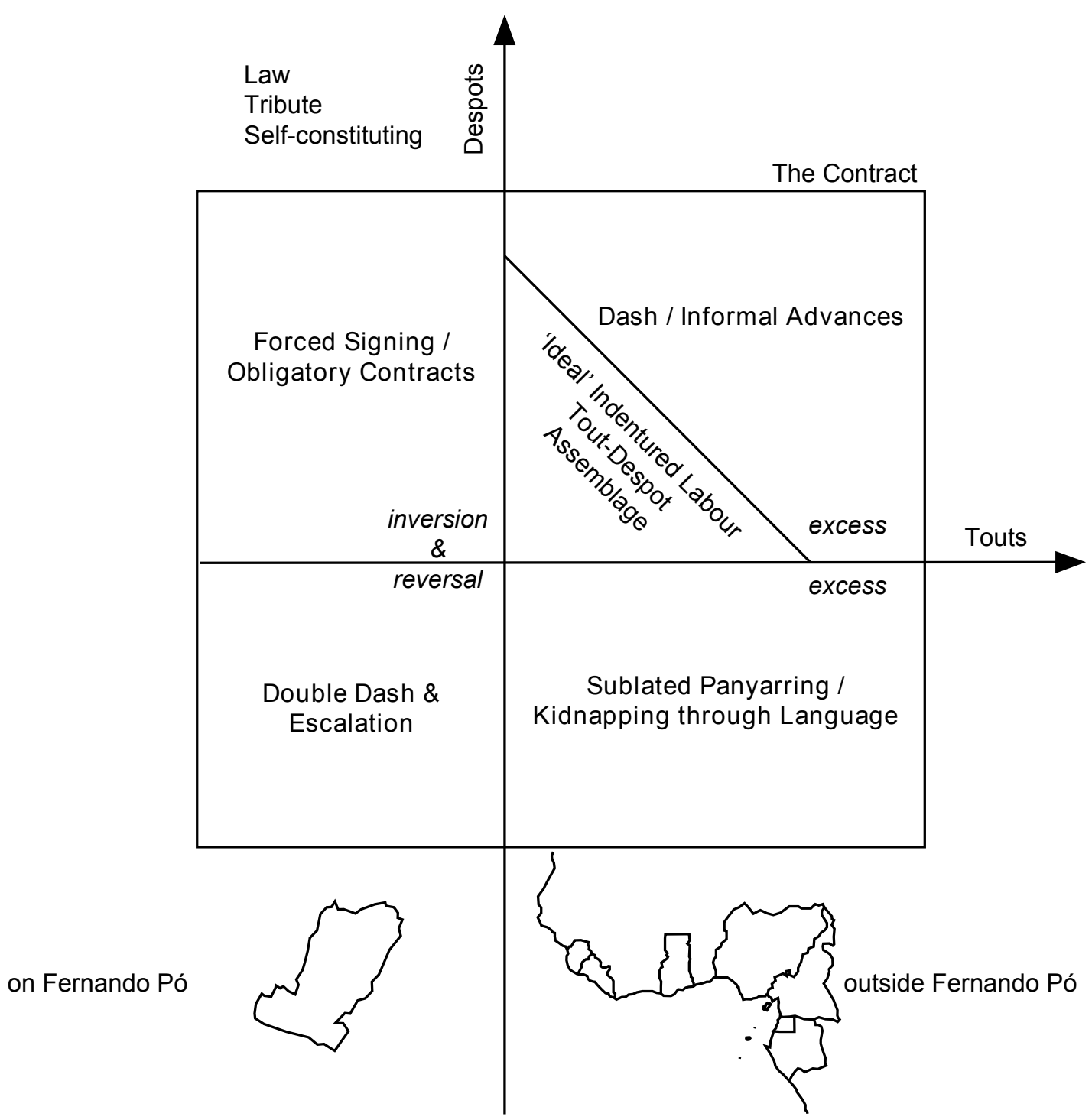

Figure 2 Tout-despot assemblages; in and through the contract

\subsection{Methods and Sources}

Panya panyarring and dash-peonaje relied on known and unknown threats and obligations. These social fabrics are not always immediately visible in the formal contours of the archive but without a doubt they saturated the socio-economic life of labour on Fernando Pó during the 1930s and 1950s. My aim or method is not to marshal up and lay out a complete documentation of events in order to satisfy or fill 
up a chronology. Historicism has been known to not adequately account for and comprehend the dimension of everyday experience and practice, but the reality of action is nevertheless detectable through the archive and its voices-spread out heterogeneously along colonial bureaucratic debris; excisions from longer correspondences, samples of serial files produced by the courts and the labour office, one-off interrogations, depositions of workers, an occasional outpouring of the press, specimens of bureaucratic logging systems, lumps of colonial regulations, single tissues from uninterrupted military dispatches, batches of statistics, and so on-even though this list is not that much longer.

This methodology is indebted to anthropology and sociology, and it allows for an understanding, a verstehen based partly on intuition, of the opaque immediacy and orality of recruitment encounters consisting largely of promises, threats and obligations revealed in a variety of sources and registers. This methodology does not require speculative leaps; instead it requires a procedural reasoning that follows the steps and webs that actors had to take and go through in order to get to their destination. To initiate and sustain movement, recruiters had to relay credits and forge scripts; and every cent and sentence should be accounted for if the question of why and how people moved is to be answered. Only recruiters and their techniques allowed for the constant appearance of plantation workers on Fernando Pó.

For my dissertation a key piece of evidence comes from a single source that explains the operation of the entire social field. The quality of encounters can be gleaned from fragmentary records around a single piece of the archive, namely the contract. There is something very abstract about the contract. In the Spanish colonial archive it is only found as either a blank template or a ragged specimen confiscated from a deserter or forger. It is a despotic form pre-set by the colonial printing press and a format that can become "peopled by a spiral." ${ }^{26}$ These potentials in the contract had an active trajectory; each time a contingent event, enabling and eliminating possibilities. Panya and dash emerged from their own creative doing. They are not always implied in the contractual artefact but only the contract can explain and posit them as a sequence or

\footnotetext{
${ }^{26}$ Gilles Deleuze and Félix Guattari, A Thousand Plateaus: Capitalism and Schizophrenia (Minneapolis: University of Minnesota Press, 1987), 489.
} 
loop of unpredictable effects. The contract is a point that allows these practices to cause themselves and go well beyond the intended parameters of the contract itself. As the contract is a shared template across many colonial archives, a closer examination of it allows for a wider conceptualization of the historical dynamics of the global history of free and unfree contract labour in and around the labourdemanding centers of post-abolition modern empires.

Global history, as Christian De Vito has reminded labour historians, is partly a spinoff of the "conceptualization of space" and carries with it "major methodological implications for global labour historians. In this perspective, 'the global' does not primarily refer to world-scale space, but rather to methodology." The "global" ceases to be "a synonym for 'world' and becomes a mind-set by which specific connections, transfers and movements of people, goods and ideas are visualized." ${ }^{27}$ In Global Labour History, it is Marcel van der Linden who has done most to connect these dimensions, opting for the term "teleconnections, after the example of geologists and climatologists who [have] demonstrated many linkages between regions located at a remote distance from each other". ${ }^{28}$ The remoteness can be bridged by doing, what Joseph Millers calls an empirically "comprehensive" contextualizing at an "analytically comprehending scale", that does not aim to be "ahistorical" or to be

${ }^{27}$ Christian De Vito, 'New Perspectives on Global Labour History: Introduction', Workers of the World 1 (2013): 5-30, 14; See also Antoinette Burton, 'Not Even Remotely Global? Method and Scale in World History', History Workshop Journal 64, 1 (2007): 323-28, 326; and her methodological claim that 'the 'problem' entailed by world history is one primarily of method and scale rather than of local/global as such". As Frederick Cooper, Colonialism in Question: Theory, Knowledge, History (Berkeley: University of California Press), 93, 110, says: "That global should be contrasted to local, even if the point is to analyse their mutual constitution, only underscores the inadequacy of current analytical tools to analyse anything in between". His solution is a rigorous empiricism that relies on conceptual metaphors of relation, but without a focus on the potential abstraction they effect: "to address questions of territory and connectivity [we need] concepts that are less sweeping, more precise, which emphasize both the nature of spatial linkages and their limits [which] specify how commodity circuits are constituted, and how connections across space are extended and bounded." See also Frederick Cooper, 'Back to Work: Categories, Boundaries and Connections in the Study of Labour', in Racializing Class, Classifying Race: Labour and Difference in Britain, the USA, and Africa, ed. Peter Alexander and Rick Halpern (New York: St. Martin's Press, 2000), 213-32.

${ }^{28}$ Marcel Van der Linden, Workers of the World: Essays Toward a Global Labor History (Leiden: Brill, 2008), 373; see also Marcel Van Der Linden, 'Introduction', in Humanitarian Intervention and Changing Labor Relations: The Long-Term Consequences of the Abolition of the Slave Trade, ed. Marcel Van Der Linden (Leiden: Brill, 2010), 1-45, 39. I think what is meant is something like "imperial formations", a wonderful term used by Ann Laura Stoler and Carole McGranahan, 'Imperial Formations', in Imperial Formations, eds. Peter Perdue, Ann Laura Stoler, and Carole McGranahan (Santa Fe: School for Advanced Research Press, 2007), 3-42, 8. 
empire-centric in order to present "an unintegrated set of separate regional narratives, presented comparatively, and thus contrastingly, rather than as the coherent sequence of incremental historical adaptations that they in fact formed". ${ }^{29}$

In this historical method, the sources need not always be "undermined"-reduced to their milieu or to some other deeper more personal or economical motivation-or "overmined" 30 _ examining for overstated turns of phrases, racist projections or the various idealist genealogies of European demagogues abroad. Sure, the colonial archive can be said to have been a semantic "field of force", but it was largely a praxis - prescription, description, anticipation and surprise - a wholly messy index of what colonials got themselves into. ${ }^{31}$ The pieces are archival quotes, snippets, cutouts, plastered with portraits, superimposed with their own dread. I cut them short before their ideological echo has a chance to congeal, but I also cut them up in such a way that they connect to the realities of other constellations in global history. The Global Labour History impetus is to not take too seriously the elaborate decoys and rosy hubris that European colonial jargon used to mark itself off from the pre-modern. The decentralized scholarly output of Global Labour History, with its eye for thorough entanglements and its consciousness of unity in fragmentation, amounts to a break with the prism of discourse, micro-histories, and the meta-term "negotiation" that have become the new axioms in colonial African history. ${ }^{32}$

\footnotetext{
${ }^{29}$ Joseph C. Miller, The Problem of Slavery as History: A Global Approach (New Haven:Yale University Press, 2012), 40, 132.

${ }^{30} \mathrm{On}$ this term as a critique of idealism and the linguistic turn, see Graham Harman, The Quadruple Object (Washington: Zero Books, 2011).

${ }^{31}$ I will not try to write "against the grain" of sources, but neither will I "explore the grain with care and read along it", Ann Laura Stoler, Along the Archival Grain: Epistemic Anxieties and Colonial Common Sense (Princeton: Princeton University Press, 2008), 53. The archive is not so much granular as a bunch of coded and crafted letters or more generally distinct piles of surfaces of inscription. These are not so much grains of dead dust as live splinters with their own directions.
}

${ }^{32}$ Colonial - but not pre-colonial-African history has until recently been very much underrepresented in GLH, cf. Carolyn Brown and Marcel Van der Linden, 'Shifting Boundaries Between Free and Unfree Labor: Introduction', International Labor and Working-Class History 78, 1 (2010): 4-11. 


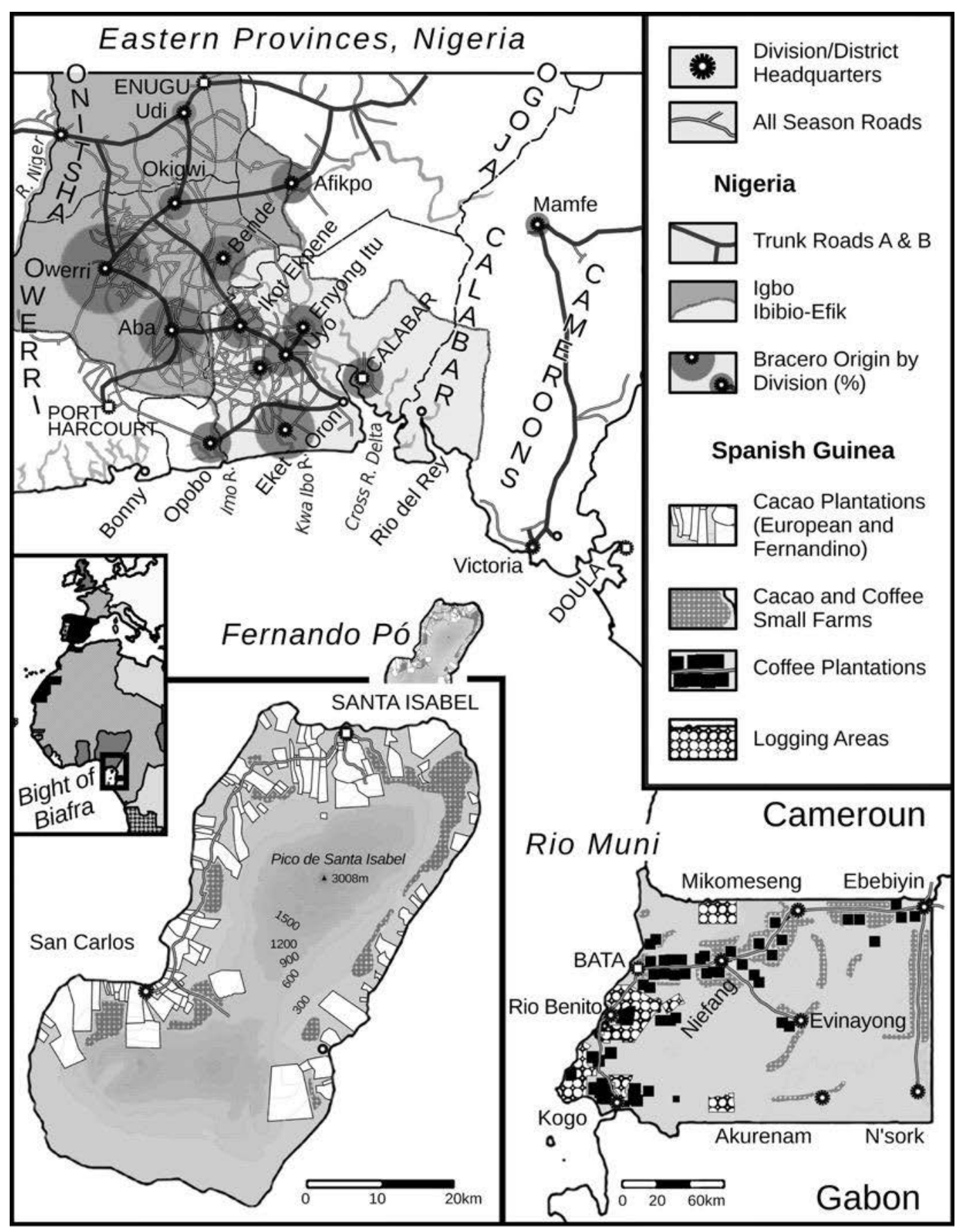

Map 1 Bight of Biafra in $1940^{33}$

\footnotetext{
${ }^{33}$ For Nigeria all five Eastern Provinces, including the Cameroons, a British Mandate territory, are visible. Provinces subdivided into several divisions, whose borders are not drawn, but their relevant headquarters are. The circles indicate the origin of Nigerian braceros by division in 1940. For Fernando Pó, land use is to actual size. Sources: Nigeria, 1940, 'A Ten-Year Plan of Development and Welfare for Nigeria', TNA, CO 657/53; Jaime Nosti Nava, Notas geográficas, físicas y económias sobre los territorios españoles del Golfo de Guinea (Madrid: Espasa-Calpe, 1942), 120-2; British VC (Michie), 28 February 1941, 'Labour Conditions', para. 29, TNA, FO 371/26908; Jaime Nosti Nava, La agricultura en Guinea española (Madrid: Instituto de Estudios Africanos, 1955), 153.
} 


\section{Imperial Formations and Atlantic Constellations}

Of the eastern Atlantic islands "only Fernando Po and the Canaries had a native population" and on both, several centuries apart, the indigenous islanders "died off". The "Europeans were free to take over the land; all they needed was people to work it." ${ }^{1}$ Labour scarcity is an ideological palimpsest of a political economy that naturalizes capitalism; its language turns the political decisions, that transformed an entire volcanic island into a settler-run mono-agriculture, into the economic necessity of recruitment. ${ }^{2}$ "The growing sums of capital invested in the island made it increasingly necessary, however, for the Spaniards to obtain labour at all costs." ${ }^{3}$ The "farmers are glad to get boys no matter how obtained, or within reason, at any cost." This is the labour market of capitalism in action, innovation in production, creative programmes for generating an uninhibited labour supply required for an extractive and expanding output. Planters were extraordinarily anxious about their labour supply

${ }^{1}$ Philip Curtin, The Rise and Fall of the Plantation Complex (Cambridge: Cambridge University Press, 1998), 22; Joseph C. Miller, 'O Atlântico escravista: açúcar, escravos e engenhos,' Afro-Ásia 19/20 (1997): 9-36; Michael Craton, 'The Historical Roots of the Plantation Model', Slavery \& Abolition 5, 3 (1984): 189-221; Sidney M. Greenfield, 'Plantations, Sugar Cane and Slavery', Historical Reflections 6, 1 (1979): 85-119; Lloyd A. Best, 'Outlines of a Model of Pure Plantation Economy', Social and Economic Studies 17, 3 (1968): 283-326.

${ }^{2} \mathrm{~A}$ somewhat eurocentric division of the world considers that by the "nineteenth century, this kind of labor scarcity was only a problem in the colonial agricultural periphery of an expanding capitalist universe", Steinfeld, Coercion, Contract and Free Labor, 5; where "only" designates a world being draped in patchworks and enclaves of export and exploitation that exploded beyond the Caribbean heartlands with the formal abolition of slavery. Cooper et al, Confronting Historical Paradigms. Economic historians of colonial Africa have placed the Nieboer-Domar hypothesis on the "causes" of agricultural slavery and unfree labour into the colonial question of scarcity. Gareth Austin, 'Factor Markets in Nieboer Conditions: Pre-Colonial West Africa, c.1500-c.1900', Continuity and Change 24, 1 (2009): 23-53, 25; Austin, Labour, Land, and Capital in Ghana, 170; Erik Green, 'The Economics of Slavery in the Eighteenth-Century Cape Colony: Revising the Nieboer-Domar Hypothesis', International Review of Social History 59, 1 (2014): 39-70. The hypothesis is straightforward enough, where land and employers made themselves abundant through colonization - and made labour 'scarce'-forms of violence in labour relations predictably followed. Evsey D. Domar, 'The Causes of Slavery or Serfdom: A Hypothesis', The Journal of Economic History 30, 1 (1970): 18-32. However Brass and Bernstein's assessment seems largely correct: the whole problem of "scarcity" was simply a "term" that was "applied by planters not to an absolute unavailability of labour-power (additional workers are needed, yet none exist) but to situations where market forces or political consciousness permit free workers to act as (and reap the benefits from being) proletarians." Brass and Bernstein, 'Introduction: Proletarianisation and Deproletarianisation on the Colonial Plantation', 17.

${ }^{3}$ Nigerian Secretariat, Lagos, [undated, 1953] 'Memorandum', RHL, 600.18 s. 21/XI (10).

${ }^{4}$ British VC (Twigge-Molecey) to Resident, Calabar, 30 November 1938, NAE, CALPROF 5/1/194. 
because they operated with a straightforward labour theory of value: no labour $=$ no output; more labourers $=$ more profit. ${ }^{5}$ It was a simple calculus: "colonization, in its economic aspect, demands putting into movement the highest number of brazos to contribute to the exploitation of colonial wealth, well agriculture, industry and commerce would not be able to exist without these concentrations". ${ }^{6}$ Recruitment brought in these concentrations from the outside.

In the second half of the nineteenth century a vanishing Empire had wedged itself into an island in the Bight of Biafra. Bent by Portuguese navigators and fastened by the slave trade, this corner of the Atlantic became embroiled in the colonial struggle for 'manpower'. From the 1860s on, agricultural labourers on Fernando Pó included deported Spanish anarchists; exiled Cuban insurgents; hundreds of emancipados or captives freed from slave ships in Havana; batches of coolie workers from China sent via Cuba in the 1890s; a continuous stream of Kru sailors from the Windward Coast contracted into bondage; the majority of the indigenous Bubi of the island that was being forced into the plantations by decree in the early twentieth century; ten thousand indentured labourers sent by members of the Liberian state from World War I on; ${ }^{7}$ and Fang from Rio Muni, Cameroon and Gabon. ${ }^{8}$ The "problema of the labour

${ }^{5}$ For a Spanish version of this Ricardo-Smith building block of political economy, see Álvaro Flórez Estrada, Exámen imparcial de las disensiones de la América con la España, de los medios de su reconciliación y de la prosperidad de todas las naciones (Cadiz: Manuel Ximenez Carreño, 1812), 120-30, 263-4. As Banaji has long argued "at the level of individual capitals, it is accumulation or the 'drive for surplus-value that defines capitalism, not the presence or absence of 'free' labour." Banaji, 'The Fictions of Free Labour', 81; 'Modes of Production', 22-4.

${ }^{6}$ Arizcun and Martínez, 'Memoria sobre los territorios españoles del Golfo de Guinea', 108, BNE, Afr/13541.

${ }^{7}$ A movement that came to an ill-famed end in 1930 with the so-called "labour scandal". Ibrahim Sundiata, 'Prelude to Scandal: Liberia and Fernando Po, 1880-1930', The Journal of African History, 15 (1974), 97-112; and his other publications From Slaving to Neoslavery: The Bight of Biafra and Fernando Po in the Era of Abolition, 1827-1930 (Wisconsin: University of Wisconsin Press, 1996), 117-22; Brothers and Strangers: Black Zion, Black Slavery, 1914-1940 (Durham: Duke University Press, 2004) 88-98, 249-250; also Nnamdi Azikiwe's Liberia in World Politics (Westport, Conn.: Negro University Press, 1970), 169-211.

${ }^{8}$ The growing labour demands of the "cacao plantations in Fernando Pó and the coffee and logging industries in Rio Muni" were briefly met in the early 1930s by Fang from Rio Muni whose "adult male population in its totality was being absorbed and submitted to salaried work". DGMC (Canovas) to GG (de Sostoa), 4 June 1932, AGA, C-81/08099, E-15, also in C-81/06415, E-2. The demands were respectively 10,000 and 6,000 annual contracts for the cacao plantations Fernando Pó and the coffee and logging industries in Rio Muni. In the first census of 1932 for the non-coastal districts in Rio Muni 
scarcity has produced a flood of decrees and provisions; well, it is of a transcendental importance. Except through divine intervention - and this I insist upon this point-we will never find a definitive solution. Those in the colony, before 1909 were already complaining of the scarcity of brazos when there were only 5000 contract workers, today [in 1945] with 27,000 contracts we are still lamenting the lack of brazos." Already from 1936 on practically all braceros on the island were Nigerian. With thousands of new settlers and a spree of corporate-backed plantations rushing in during the Francoist period (1936-1968), colonial hopes that labour needs would be met were being perpetually thwarted. As the principal chapters of this thesis will show, the vast majority of contract labourers in Spanish Guinea, up to three hundred thousand of them, were Nigerian.

On a clear day from the Calabar coastline the silhouette of the volcanic peak of Fernando Pó is discernible in the horizon. Writing in 1940, the British Vice Consul on the island says that the "Spaniards have, during the last 40 years, recruited labour from most parts of the West Coast. Thanks to their methods they have been successively obliged to abandon Sierra Leone, Liberia, and the Cameroons [as] recruiting grounds." "Now" in 1940 "they have turned the attention of their recruiters to South Eastern Nigeria and this venture bids fair to be successful. The dozens of recruiters have ample funds at their disposal; the sea journey is short and the rewards are considerable." The "traffic is now well arranged, in Nigeria by the recruiters, and in Fernando Po by the Spanish Authorities and employers. The canoes generally sail in convoys." 10 These are the broad outlines drawn out by a concise British Vice Consul. Only with the archival material laid out in the next two chapters, will we meet the motley crew of touts, traders, merchants and fishermen who brought and managed to keep labourers on the island. Here is a photograph of them at work on a sandy part of Santa Isabel's port taken by a Vice Consul in 1944.

where recruitment was carried out, some 90,000 inhabitants lived in 1300 villages. Perpiñá Grau, De colonización, 101.

${ }^{9}$ Sebastian Llompart Aulet, Legislación del trabajo de los territorios españoles del Golfo de Guinea (Madrid: Dirección General de Marruecos y Colonias, 1946), 15.

${ }^{10}$ British VC (Michie), 28 February 1941, 'Labour Conditions', para. 4, TNA, FO 371/26908. 


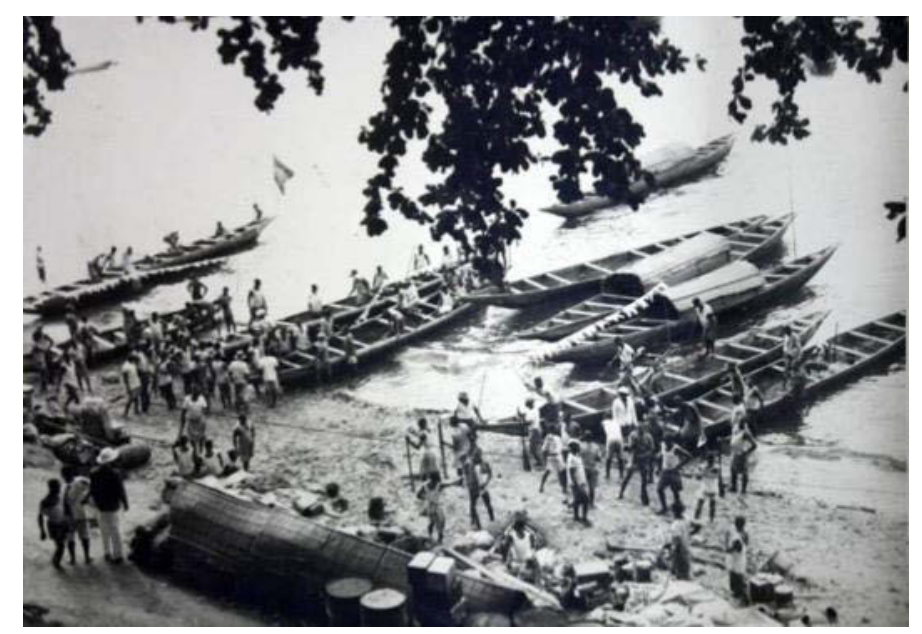

Figure 3 Smugglers arriving in Santa Isabel, $1944^{11}$

In order to get a sense of the direction and scale of the Nigerian recruiters' "venture"-which indeed bid "fair to be successful", I will in this chapter briefly draw out in quick strokes the touts who operated before them along the Gulf of Guinea. This regional frame also helps highlight the argument that Calabar's recruiters were not only localized sprouts, but emerged out of rearrangements from existing larger constellations.

\subsection{First Contracts, First Recruiters, 1850s-1890s}

In the mid-nineteenth century the British naval base and trading station of Clarence in Fernando Pó, the eventual Santa Isabel of Spanish Guinea and Malabo of Equatorial Guinea, became a staging ground for the colonization of the Niger Delta. The British had their license to the island revoked and were forced to hand it over to a Spanish naval fleet in 1859, after the latter arrived to reclaim what a 1778 lands-and-seasswapping-treaty with the Portuguese had made technically theirs. In Spain, Leopoldo O'Donnell, a former Capitán General of Cuba, had started rotating between the presidency and the ministry of war and in 1863 he founded the new colonial office, the Ministerio de Ultramar, to invade Morocco and to implement the first "Royal Decree of Colonization" in Guinea. Many of the officers of the Spanish armada

\footnotetext{
${ }^{11}$ British VC (Robertson), 31 May 1944, TNA, CO 554/139/5.
} 
dispatched to the new and very modest military outpost on Fernando Pó had started granting themselves large land concessions from the $1860 \mathrm{~s}$ on. ${ }^{12}$ The posesiones became state property because of state of war had been declared. ${ }^{13}$ In this state, anything pronounced by the Capitán General or Gobernador on site would institute rule. The despot, ${ }^{14}$ henceforth, could burn forests, and concede, title, lease and expropriate lands, and legally define labour relations.

Long before slavery was abolished in Cuba and Puerto Rico, the Spanish General of this first fleet, and first Gobernador, Carlos de Chacon, signed an order saying no one was or could be a slave on the island, initially purely on paper. Chacon converted a variety of "domestic servants", who were mostly underage quasi-slaves, into fiveyears "apprenticeships" inscribed in a governmental register of deeds and contracts. This very was the first Spanish labour regulation. It was a short one, merely assuring "rations" and "rates of pay, monthly, to be given to those over 8 years old." The government also interceded in the relation between master and servant: disputes and punishments would be mediated by "the Governor and his advisors." 15

\footnotetext{
${ }^{12}$ Presidencia (O’Donnell) to Consejo de Ministros, 9 November 1858, 'Introducción al Proyecto de Real Decreto de Colonización', AGA, C-81/07050; García Cantús, 'Fernando Poo', 370, 567. It does not mean they made successful planters. It took a while "until the first Spanish settler with any success emerged. This was Francisco Romera an official from the Armada, who came with some experience gathered from [the plantations] in Cuba".

${ }^{13}$ 'Decreto', 12 November 1868, in Ministerio de Ultramar and Adelardo López de Ayala, Memoria presentada a las Cortes Constituyentes por el Ministerio de Ultramar (Segovia: Imprenta de la Biblioteca Universal Economica, 1869), 101-8. See also Carlos Petit Calvo, 'Detrimentum rei publicae: Constitución de España en Guinea', in Constitución en España: Orígenes y destinos, ed. José María Portillo Valdés and José María Iñurritegui Rodríguez (Madrid: Centro de Estudios Políticos y Constitucionales, 1998), 425-94. The author has an English and German version of this interesting piece of legal history, see bibliography.
}

${ }^{14}$ Despot is of course derived from medieval Latin despota from the Greek despotes: 'lord, master, owner' or 'absolute ruler'. By using the term despot, I might cause some confusion, because I mean the opposite of the-anyhow much revised image - classic ancient despot who grew into a "militaryindustrial complex, in which the balance of forces was the precise opposite of ours, for the profits, insofar as that word is applicable, went to the government and its agents." Moses Finley, The Ancient Economy (Berkeley: University of California Press, 1973), 161.

${ }^{15}$ García Cantús, 'Fernando Poo', 434-6. On abolition see Sundiata, From Slavery to Neoslavery, 54, 50; Miers and Roberts, 'The End of Slavery in Africa', 16. Slavery was abolished in Puerto Rico in 1873 and in Cuba in 1886. 
These first naval officers immediately brought in a brigade of condemned Andalusian anarchists and dissidents from Malaga to try to work the land. Most of the prisoners were worked to death or died even before getting off the boat. The "ten-year sentences of residence on Fernando Poo" that were being handed down to Spaniards and Spanish imperial subjects were "in lieu of a death sentences"- and were in effect a commuted death sentence, a prolonged death by other means. The dying of Spanish prisoners en masse "produced an imaginary of the island of Fernando Poo in the peninsula as a damned hell" - the same term of non-endearment the island was prefixed with in Nigeria even a century later. Several boatloads of Cuban political prisoners and a large dose of Aragonese anarchists continued to arrive. Up until 1895 almost two thousand political prisoners were sent to the island, their arrival peaked with every anti-monarchical and anti-colonial revolt in Spain, Cuba and the Philippines. From Spain insurgents "with revolutionary sympathies", "suspect teachers imparting revolutionary ideas", "vagrants from the port towns", were all put to "forced labour on agricultural enterprises" and farmed anything from tobacco to chickens. The "state of emergency proclaimed with the arrival of the early exiles was not lifted until 1904". ${ }^{16}$

At the same time as the early experiment in penal transportation, in the 1860 s the Spanish brought over five-hundred emancipados or "those recaptured from slave ships" from Havana. The released captives had been offered a tortuous way back to the African continent on seven year indentures, after which they were to be "granted their unconditional freedom." The majority died before their contracts expired. Those who survived made up an important nucleus of the Fernandinos - who were largely made up of "liberated captives" that the British had hired in Sierra Leone and brought to the island. ${ }^{17}$ For almost a decade after 1827 the port of Clarence (Malabo) was a British naval base that was set up to track down European slave traders, set fire to the coastal barracoon or slave dens, and sign treaties with monarchs and rulers along the

\footnotetext{
${ }^{16}$ Gabriel, 'Más allá de los exilios politicos', 211; Sundiata, From Slaving to Neoslavery, 49-50, 54; Curtin, Death by Migration, 110; Foreman, The Philippine Islands, 539.

${ }^{17}$ Sundiata, From Slaving to Neoslavery, 52; Sundiata 'The Rise and Decline', 29; García Cantús, 'Fernando Poo', 437, 515; "Emancipado emigration was prohibited in September of 1866." "In 1869 there were only 150 emancipados, 120 men and 30 women" left. Liniger-Goumaz 'La cuestion bracera', 527; Sampedro, 'Engaging the Atlantic', 917.
} 
Bight of Biafra. The naval station was briefly the site of one of the Mixed Commission Courts set up to prosecute the staff on board slave ships - a " "horde of miscreants, the refuse of all nations." About a thousand clerks from Freetown and "liberated captives" remained on an island. From the beginning, around the emerging creole settler population gathering around Clarence there were several hundred "transient" Kru workers with their own peri-urban "Kru-Town". ${ }^{18}$ The Kru were an agglomerate group of, eventually Liberians, who lived around Maryland and Cape Palmes. Cape Palmes was sucked into the very centre of British imperial labour recruitment. Kru were described by colonial employers, during the peak of indenture, as the " "the Chinese of West Africa." Over 50,000 West Africans were recruited to the British and French Caribbean in the mid-nineteenth century. ${ }^{19}$

A British naval officer on Fernando Pó writing in 1850 observed with dismay that it was "cheaper to transport these men" from the Kru coast "nearly two thousand miles to perform this work, than it was to employ the liberated Africans residing on the Spot". Fernandinos "had learned to read" and also "hired the Kroomen to work their farms for them." ${ }^{20}$ As soon as the Spanish colonial authorities arrived on the island in 1859 they "almost immediately began plans" for an "improved dock" and the like and "started to flatten the terrain and build our houses". They also immediately lamented that the indigenous "boobies" were "completely useless for labour and we can expect nothing from them if that land is to prosper". They had to turn to the Kru, the "crumanes whom we are forced to go looking for on the coast". ${ }^{21}$ The first Gobernador, Chacon, himself went off to Liberia himself and had with him a type of

\footnotetext{
${ }^{18}$ Sundiata, From Slaving to Neoslavery, 22, 31; citing Nichols to Hay, 31 March 1831, TNA, CO 82/4; Lynn, Commerce, Christianity and the Origins of the 'Creoles' of Fernando Po, 256, 261; Robert T. Brown, 'Fernando Po and the Anti-Sierra Leonean Campaign: 1826-1834', The International Journal of African Historical Studies 6, 2 (1973): 249-64.

${ }^{19}$ Martin, 'Krumen "Down the Coast"', 402; Lovejoy, Transformations in Slavery, 146-7; ClarenceSmith, 'Emigration from Western Africa', 45-8.

${ }^{20}$ Henry Vere Huntley, Seven Years' Service on the Slave Coast of Western Africa (London: T.C. Newby, 1850), 167; cited in Sundiata, 'The Rise and Decline of Kru Power', 28.

${ }^{21}$ Presidencia (O’Donnell) to Consejo de Ministros, 9 November 1858, 'Introducción al Proyecto de Real Decreto de Colonización', AGA, C-81/07060, cited in García Cantús, 'Fernando Poo', 370. See also Sundiata, From Slaving to Neoslavery, 51; Clavero, Bioko, 19.
} 
published manual, a "guide for commercial transactions" on the West African coast in which the Spanish author gives advice on how to handle negotiations with "a good dose of diplomacy" and the delicate steps required to recruit Kru labour-which dashes for whom, the going rate in different areas and the not so obvious rates of equivalence of the "objects of value that represent money" such as gunpowder, rum, tobacco, manillas, and linen. ${ }^{22}$ When the first Spanish naval ships set off to recruit labour on the Kru coast in the 1860s, they were advised by the Colonial Office in Madrid "not to hand over excessively extravagant commissions to intermediary interlopers, in light of the repugnance with which the English are beginning to see the matter." ${ }^{23}$ Nevertheless, labour migrants in the island were quite 'free' in the mid nineteenth century.

Richard Francis Burton - a British colonial officer extraordinaire-achieved renown through many things, but being one of the first Consuls on Fernando Pó in the 1860s was not one of them. During his short tenure on the island he talked in very resentful terms about the Kru there. Even though they were "employed all the day long", Burton describes the scene as "quite the counterpart of a landowner's existence in the Southern States" before the American Civil War. Labour relations, "the curse of free labour", says Burton, looked something like this: "It is true these fellows have no overseer, consequently there is no whip; punishment resolves itself into retrenching rum and tobacco; moreover, they come and go as they please." ${ }^{24}$ There were no

\footnotetext{
${ }^{22}$ Joaquín J. Navarro, Apuntes sobre el estado de la costa occidental de Africa y principalmente de las posesiones españoles en el Golfo de Guinea (Madrid: Impr. Nacional, 1859), 133-134; García Cantús, 'Fernando Poo', 434, 372; Castro and Calle, Origen de la colonización española en Guinea Ecuatorial, 209; Clavero, Bioko, 19.
}

\footnotetext{
${ }^{23}$ Ministro de Estado, Madrid to GG (Montes de Oca y Aceñero), May 1881, AGA, C-81/07123, cited in García Cantús, 'Fernando Poo', 426. British abolitionists were careful in their assessment. The reverend Clarke in a meeting of the Anti-Slavery Society responded to a misunderstanding when he explained he witnessed people being "purchased on the Kroo coast" claiming: "I did not say they were positively purchased. I said a price was paid for them." To which Laird, a navy man in the audience interceded ironically: "That is a nice distinction." British and Foreign Anti-slavery Society, Proceedings of the General Anti-Slavery Convention, Called by the Committee of the British and Foreign Anti-Slavery Society, and Held in London, from Tuesday, June 13th, to Tuesday, June 20th, 1843 (London: J. Snow, 1843), 261.

${ }^{24}$ Richard Francis Burton, A Mission to Gelele, King of Dahome (London: Tylston and Edwards, 1864), 15.
} 
commodity plantations on the island then and so no sign of indentured contracts yet and therefore no outgrowth of new type of labour recruiter.

The benchmark for the island's contracts was laid only with the arrival of the Spanish, and in 1862 they added onto them the duration and conditions borrowed from the mould written up for Chinese coolies in Cuba. This Cuban template of indenture was given to the Spanish by the British when they effectively arranged the hiring of Chinese coolies for them in the 1840s. ${ }^{25}$ Even though the Spanish had directly transplanted these Atlantic indentured contracts onto the island in the late 1860s, the principal African labour force on the island, the Kru, had managed to negotiate with Spanish recruiters and bargain down the terms of service from an unworkable official ten years - that like for the Spanish convicts would have been effectively a prolonged death sentence by other means. The Spanish "colonial government had no choice but to assuage the conditions of contract".

A recruiter on board a Spanish navy ship in 1864 set a precedent by "contracting 24 Kruman in Cape Palmes for a stay of only two years at 4 pesos a month"-indeed this minimum duration would barely change for exactly the next century, until the Nigerian state, under a revised labour treaty, agreed to extend the minimum length of service to three and half years. ${ }^{26}$ This duration was in the upper limits of the existing expectations on the Kru coast, where residents had become used to being "detached

\footnotetext{
${ }^{25}$ Sundiata, 'The Rise and Decline of Kru Power', 29; García Cantús, 'Fernando Poo', 515. In June 1847 the first culies landed on in Havana, at a cost of 170 pesos each, 100 of which was subsidized by the Junta de Fomento or "Council of Economic Development" and paid over to Zulueta and Company - a London based undertaking set up to recruit coolies in the recently conquered British treaty port city of Amoy or Xiamen. The man behind the logistics was the brother of the eminent Cuban landowner and businessman Julian Zulueta, both "old hands at importing slaves"-indeed Julian has been described as the "last great slave trader of Cuba". Until 1874 some 125,000 Chinese coolies landed on the island. Another 100,000 coolies were taken to Peru-the mortality rate on board was $12 \%$. In the 1872 Cuban census someone counted 58,400 Chinese, many of whom had had their eightyear indenture prolonged by the criminal justice system. Hu-Dehart 'La Trata Amarilla', 167; HuDehart, 'Chinese Coolie Labour in Cuba', 68; Yun, The Coolie Speaks, 15; Hugh Thomas, The Slave Trade: The Story of the Atlantic Slave Trade, 1440-1870 (New York: Simon and Schuster, 1997), 9.

${ }^{26} \mathrm{GG}$ (Ayllón) to DGMC, 21 May 1864, 'Se adjunta nuevo convenio de Contratación', AGA, C81/06941; cited in García Cantús, 'Fernando Poo', 439, 442. For the previous horrific ordinance that Cantús simply calls the "forced labour" one, see GG (Ayllón), 9 December 1862, "Proyecto de reglamento para el regimen de los trabajadores que lleguen a esta Isla, bien sean contratados en la Costa Vecina, bien procedentes de aprehensiones hechas a los buques negreros por nuestra marina de guerra', AGA, C-81/07124.
} 
without force from land and lineage to rotate [usually in intervals of less than one year] in and out of European overseas export enclaves under a system with low, fixed wages". ${ }^{27}$ Already in the late 1860 s Fernando Pó was low on their list of preferred destinations, though it was someway up from Cuba. Spanish recruiters on board the official steamers dispatched to Cape Palmes in the late 1860s were told that the Kru were "by nature suspicious and mistrustful" and so they advised "not to joke around and especially not to mention the island of Cuba or Havana, well these names are odious to them, otherwise they might think that they were being misled". ${ }^{28}$

The Kru on Fernando Pó were an ever-swelling and diminishing "recalcitrant 400 man encampment", and with every passing steamer stopping over in Fernando Pó, a considerable number were lost "through desertion." 29 Indeed every time a British ship was stationed in port, a few dozen "Kruman would disappear." The Kru were mostly employed by the Spanish colonial government, in any case it seems they "made sure to flee from the island whenever opportunities arose." If "we don't find an energetic remedy" to the "flight of the Kruman", writes an early Spanish Governor, "it will be a stimulus to a series of successive desertions which will leave our Government and population without a single worker." 30 That the primary worries of the Spanish Governor lay in desertion is clear from a 1862 Labour Treaty signed with the Kingdom of Bimbia on the shores of Mount Cameroon, located within a direct line of sight of the island. All five short articles are geared towards "King William I" of Bimbia "fulfil and making his subjects fulfil the contracts with Spanish subjects" so as "to avoid the frequently arsing problem" of desertion. ${ }^{31}$ The colonial labour

\footnotetext{
${ }^{27}$ Schuler, 'Kru Emigration to British and French Guiana', 180. Kru were exceptional in terms of a disposition to enter indenture labour market: "it was difficult to find African societies which would participate in labor traffic on such terms, especially when they discovered how erratic repatriation could be." See also Martin, "Krumen "Down the Coast"; Frost, Work and Community Among West African Migrant Workers, 31-3.

${ }^{28 ، R e a l ~ O r d e n ~ d e ~} 28$ septiembre 1867, Trabajo Indígena, Contratación krumanes’, Article 8.

${ }^{29}$ Sundiata, 'The Rise and Decline of Kru Power', 29; Brooks, The Kru Mariner, 25.

${ }^{30}$ GG (Gándara) to DGMC, 19 June 1861, AGA, C-81/06941, cited in García Cantús, 'Fernando Póo', 416.

${ }^{31}$ GG and King William, 1 February 1862, 'Convenio con el Rey de Bimbia'.
} 
contract was of course on the very very surface of things opposed to and might have even been "intended to act as a deterrent to coercion, but in reality its more practical purpose was to alert labourers", however recruited, "to the penalties for desertion." 32 Indenture "borrowed from the sailor's contract" that stipulated "the length and type of service required [but], above all, the penalty for desertion." 33 But the Kru had no kings, and bounty-hunters or identity cards could not yet track them down, only their "headmen" knew who they actually were. These headmen were a mixed bag, though often enough they were far from loyal collaborators or overeager contract enforcers. ${ }^{34}$ European "steamers" were recruiting as many as 20,000 workers from the Kru Coast each year in the late $1860 \mathrm{~s}^{35}$ and indeed in the 1870s it became official policy of the Spanish - probably because they found it easier to feed off the existing flows of Kru mariners - to offer dashes to those who deserted "from the British vessels" to Fernando Pó. ${ }^{36}$

Several hundred Kru did continue to arrive almost every year on Fernando Pó for the next few decades, but their arrival was by no means guaranteed. In 1869 for example, the Gobernador dispatched a Spanish ship full of supplies to the Kru coast for the "sole purpose of recruiting 300 krumanes". They stopped to negotiate at over 10

\footnotetext{
${ }^{32}$ Anderson, 'Master and Servant in Colonial Kenya', 463.

${ }^{33}$ Stanziani, 'Beyond Colonialism', 71; Steinfeld, Coercion, Contract, and Free Labor, 35.

${ }^{34}$ Tonkin, 'Creating Kroomen', 35; Frost, Work and Community Among West African Migrant Workers, 40; The "headman" who "for his efforts" "receives the first month's wages of the persons he supplies and pockets thuse." Johnson et al., Proceedings of the General Anti-Slavery Convention, 260; also Dop and Robinson, Travel Sketches from Liberia, 574.
}

${ }^{35}$ Sundiata, Brothers and Strangers, 65 . Kru were employed by almost all colonial shipping and public works departments in the late nineteenth century, for example the Gold Coast railway in 1901, all over the British stations in the Oil Rivers Protectorate in the 1890s, and for the building of the Lagos Port and railroad north of Lagos in the early 1900s. "Liberians were poorer than Nigerians and other West Africans it seems, and Krumen were willing to work for low wages. To the merchants of Lagos and the officials of the Protectorate, they were a bargain, at 1 pound a month or 9d daily." Martin, 'Krumen "Down the Coast", 409. More famously the French also recruited Kru to work on the failed first attempt to carve the Panama Canal in 1885 arranged by the same management team that buildt the Suez Canal, for which Kru labourers were also recruited, see Frost, Work and Community, 20. Fruther on Kru see also Behrens, Les Kroumen de la côte; Renault, Libération de l'esclavage et nouvelle servitude.

${ }^{36}$ GG (García Tudela), 14 December 1873, 'Informe demostrando y enardeciendo la necesidad y la conveniencia de abandonar dicha colonia y sus dependencias', AGA, C-81/06939; cited in García Cantús, 'Fernando Poo', 515. 
coastal Kru settlements around Cape Palmes but to no avail, so they headed west to Monrovia and turned "to the Liberian Governor and a Dutch merchant, from whom they only managed to buy 3 krumanes". The ship's captain says, "the rest, a hundred or so were lined up and ready to embark but refused once they heard they would end in the hands of private employers on Fernando Poo." ${ }^{37}$ When a little earlier the British Consul, Richard Burton had passed through Cape Palmes in eastern Liberia to enlist workers, he "failed in recruiting men. 'Nanny [Fernando] Po' was a word of fear to the Krumen; they had been made to work in gardens and on the roads." "Some of them had been engaged for one year, not two, and had been kept for three." Hearing Burton's fellow travellers on the steamer speak "a few words of Spanish" they deemed him to be “"a Panyer,' [a Spaniard] and resolutely refused, with characteristic independence, to accompany" him. ${ }^{38}$

Fernando Pó consistently retained this reputation so after the departure of braceros after every round of the contracts they always came from somewhere else. As Fernando Pó's reputation headed off on a downwards spiral new Kru labourers had stopped coming altogether in the 1890s. In 1900 there were 1000 Liberians, mostly non-Kru, working on Fernando Pó. That same year there were over a thousand British West African labourers on the island, many from Sierra Leone but also from Nigeria (categorized as 'de los lagos' and 'Calabares' - 'the Lagosians' and 'Calabarians' or largely Yoruba and Ibibio). ${ }^{39}$ Next I examine how these arrived.

\footnotetext{
${ }^{37}$ Jefe de la Estación Naval (Rafael Alonso) to GG (de Souza), 13 January 1869, AGA, C-81/06941; cited in García Cantús, 'Fernando Poo', 445.

${ }^{38}$ Richard F. Burton, Wanderings in West Africa from Liverpool to Fernando Po, Vol.II (London: Bradbury and Evans, 1862), 2; For "Nanny Po" and its meaning, see Davis, Ethnohistorical on the Kru Coast, 57.

${ }^{39}$ Sundiata, From Slavery to Neoslavery, 130, 129; It is unclear how many were actually Kru, not many, most "laborers leaving Liberia were" low caste Vai and Mandinka, and Kpelle. In the 1890s, "one plantation alone was employing 200 migrant workers (Kru, Gold Coasters and Sierra Leoneans), and by 1901 there were 993 Liberian laborers in all on the island." Sundiata 'The Rise and Decline of Kru Power', 35; citing Brooks, The Kru Mariner, 25; Terán, Síntesis Geográfica, 78.
} 


\subsection{Tout Preludes: Fernandinos and Agudas, 1880s-1910s}

Cacao plantations on Fernando Pó did not kick off until the 1880 s, even though already during the mid-nineteenth century a Fernandino, William Pratt, with experience travelling through the Caribbean, as well as a Spanish agronomist, brought over cacao pods to the island after separate trips to São Tomé. The first export of a monoculture, yielding $500 \mathrm{~kg}$ worth of cacao and requiring a significant number of braceros was in $1884 .{ }^{40}$ In the late $1880 \mathrm{~s}, 80 \%$ of all plantations (some $630 \mathrm{~h}$ ) were in the hands of Fernandinos. These were all situated on the coast, an area of colonial encroachment the Bubi had stayed clear off since the height of the transatlantic slave trade in the Bight about a century previously. These coastal lands had been acquired by Fernandinos through a mix of government concessions, localized armed violence and as compensation for unsettled commercial debts of palm oil and alcohol. ${ }^{41}$ These first successful cacao plantation had been single-handedly set up by ambitious Fernandinos, such as the Barelycorns, Maximilano Jones, and William Allen Vivour. They hailed from Freetown or the various Creole towns around Freetown. Their once enslaved parents or grandparents were most likely from Nigeria. ${ }^{42}$

\footnotetext{
${ }^{40}$ Terán, Sintesis geográfica, 84; Sundiata, Equatorial Guinea, 24; Clarence-Smith, Cocoa and Chocolate, 104; Jose Cesar Banciella, 'Spanisch-Guinea', Deutsche Kolonial Zeitung, Berlin, May 1942, BArch, NS 5 VI / 927449 B310.

${ }^{41}$ In the 1890s a Catholic missionary complained: "The island of Fernando Po above all has been captured by the English blacks of Sierra Leone". "These foreign English blacks have for the most part, the better coastal soil." Fernandez, Misiones y Misioneros en la Guinea Española, 109; cited in Sundiata 'The Rise and Decline', 36. For earliest account of hesitant Bubi interaction with British slavers see, José Varela, 1780, 'Descripción de la Isla de Fernando Poo', AGS, Estado, Legajo 7411, Documento 26.

${ }^{42}$ Sundiata, From Slaving to Neoslavery, 23, 130. Sundiata notes that the British in Sierra Leone estimated in 1821, that $42 \%$ slaves leaving Old Calabar were Ibibio, and $56 \%$ Igbo. Most recaptured slaves sent to Sierra Leone were 'Nigerian'. The other important early figure was "a São Tomense Mulatto, Laureano Dias da Cunha Lisboa, trader, planter and Portuguese consul on the island." $\mathrm{He}$ "went to Freetown and personally took back labourers to their estate, then he sent his agent Thomas Graham for more.” The recruits were Mende from Sierra Leone; also García Cantús, 'Fernando Poo', 567.
} 


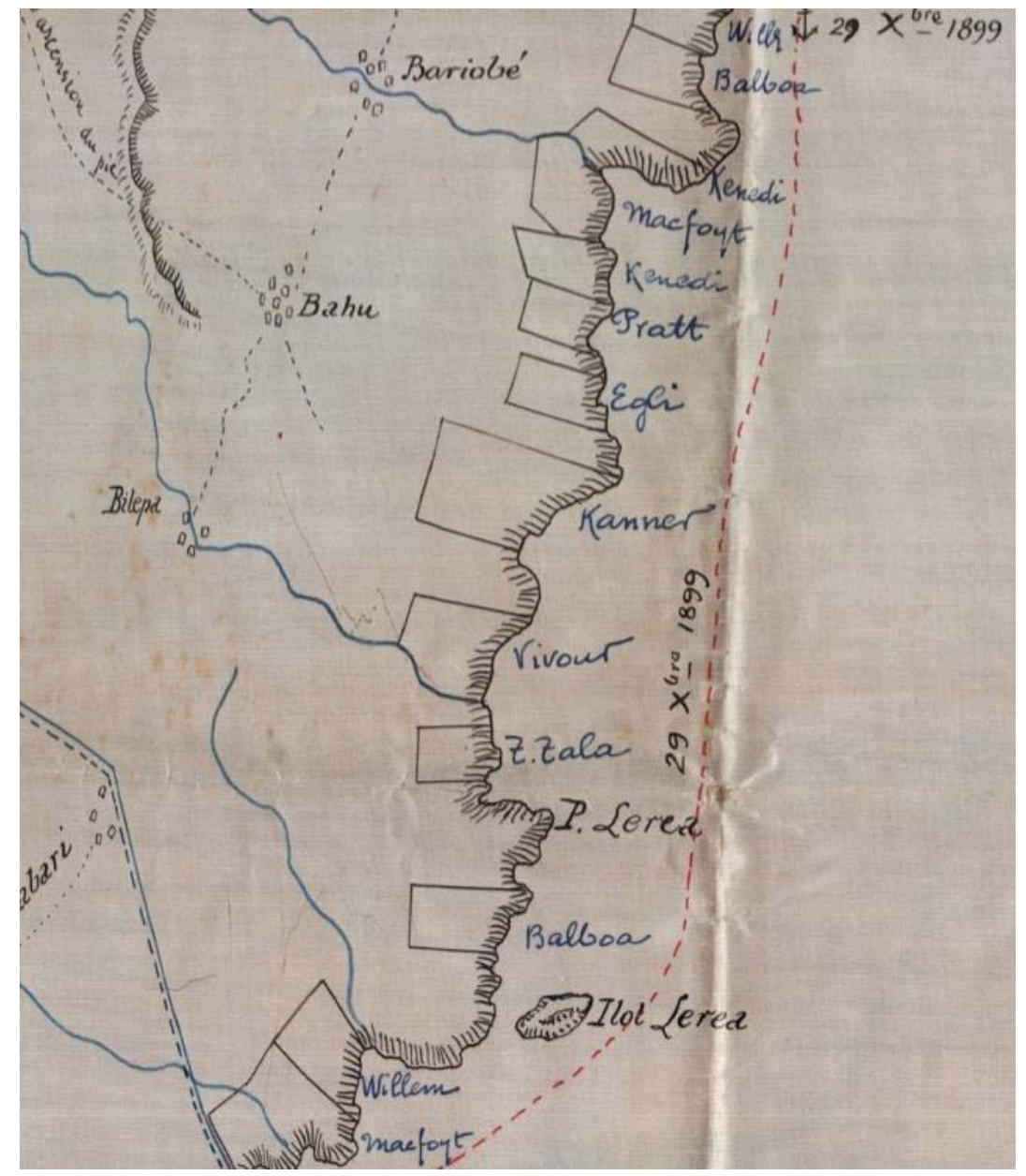

Map 2 Fernandino plantations on the east coast, $1901^{43}$

Vivour, a bricklayer by trade, had become a palm-oil agent of the John Holt Company on the island in the 1870 s and was used to travelling around the Gulf of Guinea and Europe too. Vivour himself soon became the largest planter on the island. He had up to a hundred labourers at any one point. He was very distrusting of his hired subordinates but more often than not he recruited with the help of "two Bassa-people stationed on the coast"-Bassa, a Kru coastal group whom a resident German scientist on Fernando Pó in the 1880s paradoxically decided to describe as both "very lazy, and unsettled and restless, and who assimilate quickly into the ranks of the Poto"

\footnotetext{
${ }^{43}$ Balboa, Kenedi, Macfoy, and Vivour had their plantations on the southeast of the island north of Riaba or Concepción. Bariobé, Bahu, Bilepa are names of bubi villages uphill and upstream from the plantations. Inset of Map: 'Ile de Fernando Põo', 1901, BNM.
} 
or Fernandinos. ${ }^{44}$ To get workers these new generations of creole planters and recruiters traversed whatever port towns were connected by steamer, anywhere where "free immigrants" or "slaves escaping their servitude" had "flooded" the "coastal towns", including Accra and Loango, but especially Lagos and Freetown both of which were becoming a type of "floating" "labour reserve for all of West Africa". 45

This confluence of labour in the coastal trading towns and the more flexible relations that could result "seemed to have blunted somewhat the distinctions between slave, indentured servant, pawn and free labourer"; also because especially in the 1890s "slaving, brigandage, panyarring and pawnship became fused in disconcerting ways". ${ }^{46}$ Some of the recruited workers could also turn this fusion into its opposite and establish themselves as independent planters after a contract on the island. From Freetown, a letter to a newspaper retells how the movement of "the aborigines from this country who went to that Island as farm labourers", involved people "who a few years ago [were] worth nothing, [and] are now being enriched." A letter from a Fernandino planter cited in this newspaper expounds the progressive coupling of social mobility and class formation: "Farming is as paying job here: you will be astonished to know what insignificant Mendi, or Limbah or Timni who have now become planters make annually, hundreds of pounds." ${ }^{47}$ Indeed it was also through

\footnotetext{
${ }^{44}$ Sundiata, From Slaving to Neoslavery 130; Clarence-Smith, Cocoa and Chocolate, 80; On the "fabelhaf reich" Vivour see Oscar Baumann, Eine afrikanische Tropeninsel Fernando Poo und die Bube (Wien: Hölzel, 1888), 140, 137-8. "Vivour beschäftigt derzeit grösstenteils Loangomänner, doch hat er auch etwa 30 Accra-Arbeiter (darunter Fassbinder, Zimmerleute und Schmiede), einige Cap Palmas-Krujungen, mehrere Bassamänner als Zwischenhäındler an den Küstenplätzen und vier Bube in seinem Dienste. Vivour hatte früher schon alle möglichen Arbeiter aus verschiedenen Küstentheilen im Dienste gehabt, doch geniesst er jetzt überall so einen schlechten Ruf, dass es ihm schwer wird, Leute $\mathrm{zu}$ engagieren." Baumann opposed the Bassi with the "Loangos who found the Bubi-life more attractive, many have deserted into Boloco village and are today indistinguishable from the Bubi."
}

${ }^{45}$ Phillips, The Enigma of Colonialism, 34; Kristin Mann, Slavery and the Birth of an African City: Lagos, 1760-1900 (Bloomington: Indiana University Press, 2007), 234; see also García Cantús, 'Fernando Poo', 567.

${ }^{46}$ Gerald M. McSheffrey, 'Slavery, Indentured Servitude, Legitimate Trade and the Impact of Abolition in the Gold Coast, 1874-1901: A Reappraisal', The Journal of African History 24, 3 (1983): 349-368, 360; Emmanuel Akyeampong, Between the Sea and the Lagoon: An Eco-Social History of the Anlo of Southeastern Ghana, c. 1850 to Recent Times (Oxford: James Currey Publishers, 2001), 70.

${ }^{47}$ H.H. Lardner, 'Songo Town Its Capabilities and Prospects', Sierra Leone Weekly News, Freetown, 19 May 1900. 
the return of labour migrant labour after a 'tour' on Fernando Pó's early plantations with which the cash crop spread into Ghana and the rest of West Africa. ${ }^{48}$

While many Fernandinos became landowners and successful agro-capitalists, many also became state functionaries and local managers in the rapidly expanding European plantations during the 1890s and 1900s-when the Spanish colonial state had started dishing out 50h land concessions to any Spanish settler who arrived. Most new Spanish settlers arrived from Cuba and Catalonia and were woefully unprepared to engage in the delicate and intricate task of informal recruitment on their own account. The Fernandino's knowledge of travel and the entire West coast, and large profits in hand, seemed to incite a new breed of "native labour recruiters [who] first made their appearance about 1896 [after] the period of headmen came to a close." This distinction between headmen and recruiter is an important one as we have underlined. Only in the case of Kru were the advances, labour conditions, payments and supervision mediated through Kru headmen.

A British Vice Consul traced Fernando Pó's “first” Nigerian labour tout in one Aguda man, named Bernadino Jose Reis from Brazil House in Lagos island. In the 1890s Reis began "importing Yoruba labour" from Lagos and Ijebu-Ode. ${ }^{49}$ It would be onerous to place Reis at the origin, there were "other persons besides Mr. Reis engaged labourers for Fernando Po". It is unclear who exactly he was except that his name was Bernadino Jose Reis, and that he was possibly related to a notable Aguda carpenter in Lagos. Reis does embody the new figure of the recruiter whose reign and movements into the first half of the twentieth century I will try to follow. This figure is the tout, a semi-anonymous stranger with who is semi-anonymous in his commercial relation with both capital and labour and delinked from the colonial state.

At the turn of the century, 450 labourers, most of whom Reis recruited, went on strike. After what the Spanish called the 'uprising of the Lagosians' the British embargoed

\footnotetext{
${ }^{48}$ William G. Clarence-Smith, Cocoa and Chocolate, 1765-1914 (London: Routledge, 2000), 113; For the famous case or story of Tetteh Quarshie founding the first cacao farm in Ghana around 1880 with cacao seeds he brought from the island, see Polly Hill, The Migrant Cocoa-Farmers of Southern Ghana: A Study in Rural Capitalism (Münster: LIT Verlag, 1997), 172.
}

${ }^{49}$ British VC (Michie), 28 February 1941, 'Labour Conditions', para. 4, TNA, FO 371/26908. 
labour migration to Spanish Guinea. Though the British had already planned a generalized circumscribing of the labour market of British West Africa. In 1897 "as large number of men are now being contracted to work in the Panama Canal and the Congo estuary, it has been necessary to suspend all shipments of labour from the colony [of Sierra Leone] not only to Fernando Poo but also elsewhere". 50 Nevertheless Yoruba labour had continued to arrive, and in 1900 they "marched to the Governors house in Santa Isabel with machetes in hand and refused to return to the plantations". These striking Yoruba's, were met "with guards from the navy who rushed down from the jetty". They were beaten and deported without their due pay. ${ }^{51}$ Reis himself kept recruiting for decades. In the 1910s, someone accused Reis and a new associate, another "Lagos man" by the name of Thompson of going "to Bonny and Warri to take little children to sell at Fernando Po. They have sold lots already". Reis and Thompson had a variety of liasons, as they would hire canoes to get to Rio del Rey in the German Cameroons "from whence there appears to be no difficulty in shipping them to [the] island of the Fernando Po group, where labour is very scare and in great demand". 52

The recruiting scene in the early 1900s is a recurring repeat of the experiences of "Ali", a "native of Lagos." "Ali complains that he was found by a man called Bruce in Accra, who told him that he was taking him to Calabar to work there. He was

\footnotetext{
${ }^{50}$ Francis Bertie to Minister of State, London, 29 March 1897, AGA, C-G779, cited in García Cantús, 'Fernando Poo', 576.

${ }^{51}$ J.M. Rafel, Santa Isabel to GG (Domínguez Manresa), 3 December 1932, AGA, C-81/08128, E-12. Reasons for the strike were related to working conditions. In February 1900, before the strike, 212 of Reis' recruits returned to Lagos only to lodge a complaint at the Education Office in Lagos: "they were cruelly treated", "their rations consisted of only one plantain for breakfast and a small cup of rice for dinner", "they further complained that they had not been paid their wages, but some of them received advances either in money or in kind." Henry Carr, Education Office, Lagos, February 20 1900, 'Report on the Condition and Treatment of Labourers just returned from Fernando Po', AGA, C-81/07789, E-2. Reis appears as an employer of only a few of the recruits, "in the other three agreements he appears as agent for different Merchants of Fernando Po".

${ }^{52}$ Joseph Asaba, Victoria, to Provincial Commissioner, Calabar, 22 October, 1911, TNA, FO 367/254; German West African Trading Company, Rio del Rey to Provincial Commissioner, Calabar, 17 October 1911, TNA, FO 367/254; Lieutenant Strong to Admiralty, HMS Dward, Cape Lopez, 20 November 1911, TNA, FO 367/254; The British seemed to have blocked the steamer route to the island, "the only other way to reach Fernando Poo is from the mouth of the Calabar River in canoes, a distance of 60 miles, which is unlikely to be attempted in the tornado season." Also Sundiata, From Slaving to Neoslavery, 134.
} 
landed, he says, in Fernando Po and taken before the [Spanish labour officer, the] Curador." He was then "told that if he did not sign a contract for three years he would put in gaol. He therefore signed for three years." 53 A recruiter by the name of "Mr. Davis" landed on the island with "ten Elmina boys" in 1912. "Davis recruited them in Elmina, and promised to take them to Calabar at 1s per day." When

\begin{abstract}
"the steamer left the coast and went in a direction they know to be not that of Calabar, they questioned Davis where they were going to. He said the steamer was first going to Fernando Po. When they arrived here they were made to go ashore, and then taken before the Curador, who asked them to make a contract for five years. They said they had been engaged to work cargo, and were not to do plantation work. The Curador told [them] that if they did not make a contract for five years he would send them to gaol [jail]. They then made a contract for three years. ${ }^{.54}$
\end{abstract}

Until the 1930s, the upper echelons of the both the British and the Spanish colonial state showed relatively little interest in the details of recruitment. They could feign a legal literalism, either sincerely or insincerely. They both agreed that these early migrations "cannot be described as "forced"”, as "labourers arriving from foreign territory in Fernando Po" had to make a "declaration" to "the effect that they are doing so out of their own free will." 55 This type of statement was only made by those who were distant observers, blinded by having read the legal small-print on contracts over and over again. Even when firms, particularly inter-colonial British and German

\footnotetext{
${ }^{53}$ British VC (Smallbones) to Curaduría, 10 June 1913, TNA, FO 367/353. Sundiata, From Slaving to Neoslavery, 135, citing CO to FO (Gray), 2 September 1912, TNA, FO 367/286 quotes a deposition from a Gold Coast labourer on the island in 1912: "I am a native of Amanfru, in Secondee. About 9 months ago, Benjamin, came to Amanfru and asked one, Kwakun, to get him some men to take to Calabar. [...] Benjamin asked us to accompany him to Elmina. We did so. After a week at Elmina [the] steam-ship 'Bakana' arrived and Benjamin gave us in charge of a Lagos man. [...] After 9 days we arrived at Fernando Po. The Lagos man took us ashore and handed us to one Bikitana (Vigatana?), a Spaniard. Bikitana took us to his cocoa farm and gave us matchets and set us to work at the farm. He gave us two cups of rice weekly, and some salted fish. We worked for four months, but no pay was given us. He used to flog us every day."
}

${ }^{54}$ British VC (Smallbones) to Curaduría, 10 June 1913, TNA, FO 367/353. Or take the case of Momo Bokory, from Sierra Leone who arrived in similar circumstances. He was brought to Sekondi, also in Ghana, where he was promised by a Mr. Davis that he "would earn 31 a month. When they arrived in Secondi, Davis said he was taking him to the Congo and work at that wage." He arrived in Fernando Pó and "wanted one year" as had been promised by Davis, but he was forced to sign on to four, under the same threat of gaol.

${ }^{55}$ Ministerio de Estado (Prieto) to British Ambassador (de Bunsen), Madrid, 9 February 1912, NAE, CSE 9/1/6. 
firms made their own recruiting arrangements on the coast they could not outgun the Spanish state: a British firm on Fernando Pó found itself "under an obligation to see that the boys were sent back after that time"-less than one year-to which the Curador replied: "that he was the Curador and that he would allow no one to interfere with him and he contracted the boys for three years." 56 Those landing on the island had to sign on to contracts of variable length, which was essentially a matter of a barely negotiation extortion.

In the early twentieth century, after the strike, the entirety of "the labour markets in the French and British West African possessions" became "closed for supplying workers to the plantations on this dread island which shelters under the flag of Spain." 57 The prohibition was only partially enforced and it became quickly "evident that a considerable unchecked traffic in illegally recruited native labourers of British nationality destined chiefly for the plantations of Fernando Po" was being carried out in various port town in the Gulf of Guinea. Indeed some of the principal receiver of this illicitly recruited labour in British West Africa were British cocoa exporting houses in Santa Isabel, such as the John Holt company, who "pay 5pounds for each 'boy' landed" in order to informally lend or rent these braceros to various smaller farmers on the island in exchange for their cocoa. Only colonial settlers and those with an emancipados status, an exclusive license granted to only a very small number of Fernandinos, could actually formally contract braceros. ${ }^{58}$ Regular British and German steamers extensively connected Fernando Pó to its regional world; in the early decades of the twentieth century palm oil and cacao were still being exported primarily to Liverpool and Hamburg, as well as partly Barcelona.

\footnotetext{
${ }^{56}$ British VC (Smallbones) to CO, 30 June, 1913, TNA, FO 367/353. "The chief complaint of the Liberian labourers, I understand, is that they are brought here under false pretences. They are told that they are coming for a British firm and are then handed over to Spanish, Portuguese and [African] planters, from which they receive much worse treatment that what they are used to from a British masters."

${ }^{57}$ Taylor, Jungle Trader, 79.

${ }^{58}$ British Consul General, Monrovia to Foreign Office, London, 15 October 1913 [and] 30 June 1913, TNA, FO 367/353; Sundiata, From Slaving to Neoslavery, 136, citing Lt. Strong, 5 August 1912, 'Report on the Exportation of Native Labour from Liberia to Fernando Po', TNA, FO 367/286.
} 
From this embargo, Sundiata posits a brief formula: "the labor embargo from British West Africa" served only to "increase dependence on increasingly coercive labor recruitment elsewhere." Sundiata has provided an ample and definitive account of recruitment on the western edge of the Gulf of Guinea but has assumed-and subsequently so have all the others in the field - that the Nigerian connection was more or less halted with the deportation of the Yoruba strikers in 1900 only to kick off with the Anglo-Spanish Labour Treaty in 1942. Sundiata offers brief empirical details into the unintended effects of the boycott which resulted in the continued "intercolonial struggle to secure British West African labor for Spanish Guinea". ${ }^{59}$ His focus is however between World War I and the late 1920s, when the indentured labour treaty with the Liberian state displaced the mostly Fernandino and Creole recruitertouts who had shuttled back and forth across the West African coast. Reis and his ilk did partially subside as they were being made unnecessary by state-run despotic recruiting channels in both Liberia and Rio Muni. Sundiata writes, "by the late 1920s such an individual operation would have been almost unthinkable. ${ }^{60}$ It was a strange comeback for such quasi-'individual operations' to flourish with a vengeance soon after, with methods pioneered by the likes of Vivour and Reis.

Other recruiters were operating simultaneously or followed in the steps of Vivour and Reis, but always in different places. Calabar's first large scale recruiter in the early twentieth century was Ekpenyon John Boko, from the Cobham family in Duke Town, who was "suspected of inducing boys to leave Calabar for Fernando Po without either obtaining the consent of the head of their House, or entering into a proper contract of service. ${ }^{\prime 61} \mathrm{He}$ had been taking advantage of the rising number of deserters and the newly autonomous job-seekers generated by the abolition of slavery in Nigeria 1901 and the subsequent introduction of the House Rule ordinance, under which former

\footnotetext{
${ }^{59}$ Sundiata, From Slaving to Neoslavery, 134; Sundiata, Equatorial Guinea, 43-5.

${ }^{60}$ Sundiata, From Slavery to Neoslavery, 140; see Liberia and Spain, 15 August 1915, 'Convenio entre S. M. Católica el Rey de España y el Excmo. Sr. Presidente de la República de Liberia para el reclutamiento de braceros en dicha República para trabajar en la Colonia de Fernando Poo', Boletin Oficial de los Territorios Españoles del Golfo de Guinea, AGA, C-81/8125, E-2. For original treaty negotiations and drafts, AGA, C-81/06866.

${ }^{61}$ High Commissioner's Office, Calabar to GG, 12 April 1905, AGA, C-81/07789, E-2.
} 
"slaves" now called servants were obliged to render tributary service labour to their Efik masters. The rate of flight was so high that even the "most important Chief[s]" in Calabar found it "difficult to secure enough labour for their trade canoes". ${ }^{2}$ Dozens of letters reached the Governor in Santa Isabel from a demoted Efik aristocracy now classified as "chiefs", such as from Abassi Ita of Duke House, asking about "the whereabouts of his runaway boys". The Spanish Governor happily ignored all of them and pointed the finger back "at the slavery being condoned by the English, who expect us to return these men who left their region freely". 63

After the British promulgated the House Rule Ordinance they introduced the "Roads and Rivers Proclamation of 1903" which gave "chiefs" the power "to recruit forced labour" for public works as well as recourse to the "local police in securing the capture of the chiefs' runaway subjects." As Walter Ofonogaro says, "both the House Rule Ordinance and the government's forced labour policy created fugitives, many escaping to Lagos or Fernando Po, where they threw themselves on the mercy of the Spanish authorities of that plantation island." ${ }^{64}$ Many hundred "British subjects from Southern Nigeria" and particularly from Calabar were "found to be living in a Spanish island, in order to avoid the bondage of the House Rule Ordinance [and] fear[ed] to return home again lest they become 'enslaved' under it.” In 1911 Jabez Linette was "anxious to return to his home in the Calabar district, but dare not so because he would be arrested [and then] returned to his owner." The Methodists on Fernando Pó "purchased his liberty"; it is unclear whether they kept him on as a hired labourer. ${ }^{65}$

${ }^{62}$ Olatunji Ojo, 'The Southern Nigeria Native House Rule Ordinance (1901)', African Economic History 40 (2012): 127-36, 133.

${ }^{63}$ Solicitor for Chief Marin Braid, Calabar to GG, 18 October 1905, AGA, C-81/07789, E-2; GG to DGMC, 31 December 1912, AGA C-81/06945, E-20.

${ }^{64}$ Walter I. Ofonagoro, 'An Aspect of British Colonial Policy in Southern Nigeria: The Problems of Forced Labour and Slavery, 1895-1928', in Studies in Southern Nigerian History, ed. Boniface Obichere (London: Frank Cass, 1982), 219-44, 237. The House Rule Ordinance was abolished in 1912, F.D. Lugard, 20 May 1912, 'Memorandum on the Native House Rule Ordinance', TNA, CO 520/107. On Forced labour in Nigeria see also Okolie, 'The Transformation of Eastern Nigeria', 455; Afigbo, 'The Native Revenue Ordinance in the Eastern Provinces', 71-100; and NAE, OPODIST $1 / 1 / 38$.

${ }^{65}$ John H. Harris to the Secretary of the Anti-Slavery and Aborigines Protection Society, cited in 'The House Rule Ordinance', The Lagos Weekly Record, Lagos, 8 May 1911, 3. This question was also 
In the first decades of the twentieth century, surrounded by recruiting embargoes spanning the entire Gulf of Guinea, Fernando Pó started throwing a new generations of informal recruiters at their own problema - a self-generated labour scarcity. They unfurled and incited a host of discontinuous labour suppliers across the Gulf of Guinea in an attempt to scramble themselves out of the paralyzing labour shortage on the island. Where the reputation of the island preceded the recruiters it was either misdirection as to the final destination, or call in the guards-which touts did not have. Many braceros met with death on the island, very few braceros stayed on the island as braceros, most returned because they wanted to or because vagrancy laws did not allow them to stay except as braceros. Touts always had to improvise and break new ground. Their discontinuous march came at very specific junctures. Their rhythm was precipitated and shifted by the consolidation of the imperial state, by changing political regimes, various junctions of extreme labour scarcity, and the changing composition of the mostly immigrant population. These structural conditions were quite volatile in Spanish Guinea and so waves of forms of free and unfree labour recruitment were constantly superseding each other at various turns, when a cumulative play of forces cut off certain supply-routes and release new ones.

\subsection{Despots Displace Touts in Liberia, 1890s-1920s}

The "change in Kru migration to Fernando Po" Sundiata observed, was a shift to despots: it did "not so much involve the breakdown of older patterns and the rise of coercion per se as it does the rise of external authority on the Kru Coast itself." Any of the manifold "internal pressure[s] to emigrate from the Kru Coast" were now being "increasingly substituted by the coercive machinery of the Liberian state."66 "Laissez faire recruitment was curtailed in the [1890s] when the Liberian government gave recruiting rights to a German, August Humplmayr". Humplmayr was allowed to operate along the entirety of southern Liberia and indeed the Liberian state gave him

linked to illegal recruitment. "One woman from the island of Fernando Po visited Old Calabar, and was taking back with her a domestic servant. The woman was arrested and sentenced to a long term of imprisonment, which she is now serving in Old Calabar." 'The Labour Ordinance in Northern Nigeria,' The Lagos Weekly Record, Lagos, 24 October 1903.

${ }^{66}$ Sundiata, 'The Rise and Decline of Kru Power', 30; Sundiata, From Slavery to Neoslavery, 129. 
"the exclusive right to ship small groups of laborers to all places except Fernando Po. ${ }^{, 67}$ A Spanish resident on the island in 1901 lamented these strangulation tactics, but in a sympathetic light. In the "same way that in Chinese ports, recruiting companies emerged to channel Chinese labour for the Panama Canal, the desert of Atacama, and the transandes railways, in Liberia there is one for Krumanes, established by a German company, who for a licence fee paid to the Government of this Black Republic, has come to monopolize the business exporting its inhabitants." ${ }^{\circ 8}$ The large German commercial conglomerate with a steamship line, Woerman and Company, took over this license in 1903 and Fernando Pó was put back into the list of permitted destinations. In order to "regulate" emigration and cash in or drain parts of the wage-profit nexus for themselves, the Liberian state in 1891 "established a Native African Shipping Bureau" and charged a very substantial two-dollar "fee", some of which went to "set up a register of all departing workers" in order to keep track "of all deaths down the coast as well as a schedule of fees." The three-month advances that the Kru had demanded and come to expect now went into the hands of the "Liberian treasury hovering on the edge of bankruptcy." 69

The Liberian state might have had a registry, but 'laissez faire recruitment' nevertheless reappeared. Right before the outbreak World War I, the John Holt company - that had a cocoa exporting house on Fernando Pó - called on Harold Taylor "to assist in the recruitment of labour". Taylor was a lowly British employee residing and working at an import/export 'factory' in Monrovia. Taylor says that "the best way to get results" was to venture into the "most remote of districts" in the “interior”, where 'Nanny Po' had not yet acquired a loathsome connotation. Taylor proudly retells his linguistic feats. Exaggerating somewhat, he recalls how the

\footnotetext{
${ }^{67}$ Sundiata, 'The Rise and Decline of Kru Power', 38; By the end of the century labor migration had become an important source of revenue for Americo-Liberian officialdom. The Kru became increasingly subject to Port of Entry laws, recruitment regulations, and imposts on overseas earnings. Martin, 'Krumen "Down the Coast", 409.

${ }^{68}$ Gutiérrez Sobral, 'Guinea Española: la crisis de braceros', Revista de Geografía Colonial y Mercantil 2 (1901): 12-15, 14. He continues: "Anyone who wants to contract Liberian labour has to get along with this company" which had "prioritized the request of their countrymen in Cameroons."

${ }^{69}$ Martin, 'Krumen "Down the Coast"', 416, 409; Clarence-Smith, 'Cocoa Plantations and Coerced Labor in the Gulf of Guinea', 162.
} 
"picture [he] painted [of Fernando Pó] was so glowing with gorgeous colouring, that I eventually had all my work cut out to prevent the Chief himself from signing on and excluding all others from this golden promised land." Taylor notes that as soon as he crossed into districts where people had already come and gone to Fernando Pó, touting became untenable. ${ }^{70}$ Many other private and informal recruiters who had been operating in Liberia were informing the planters on Fernando Pó that the "boys who had returned from Fernando Po gave it such a bad name that [they were] unable to induce more labourers to come here". ${ }^{71}$ Fernando Pó reputation was being continuously cemented and expanded, and so Taylor and his "native gangers" were forced to go into "ever more isolated parts of the interior" without laying "too much stress on the name Fernando Po [...] the very sound of it seemed to have a dampening effect on us." Taylor leaves his reader to imagine the conditions of the mobile encampments of recruited labourers: "Within a month we had collected close on eight hundred labourers", but on the trek back down to the coast, over an entire third "just vanished into thin air" or "died en route from a variety of unexplained causes" or had been "left behind through sickness." He dispatched the remaining recruits to Fernando Pó on German steamers as the "British Captains were very averse to [...] what they termed slave-running". 72

\footnotetext{
${ }^{70}$ Taylor, Jungle Trader, 85.

${ }^{71}$ British VC (Smallbones) to FO (Grey), 30 June, 1913, TNA, FO 367/353.

${ }^{72}$ Taylor, Jungle Trader, 85 . The way Spanish colonialist twisted true details and denied this reality is a peculiar case of delirium, which we won't get into: "The island of Fernando Poo has achieved a good reputation along the entirety of the coast, it is known as a place of abundance, an easy life, of richness for the black worker, who on his days off has plenty of money to spend, and where all braceros can acquire a wife or wives." Juan Bravo Carbonell, 'Politica de España en Africa: Los braceros liberianos para Fernando Poo', Luz, Barcelona, 22 December 1932.
} 


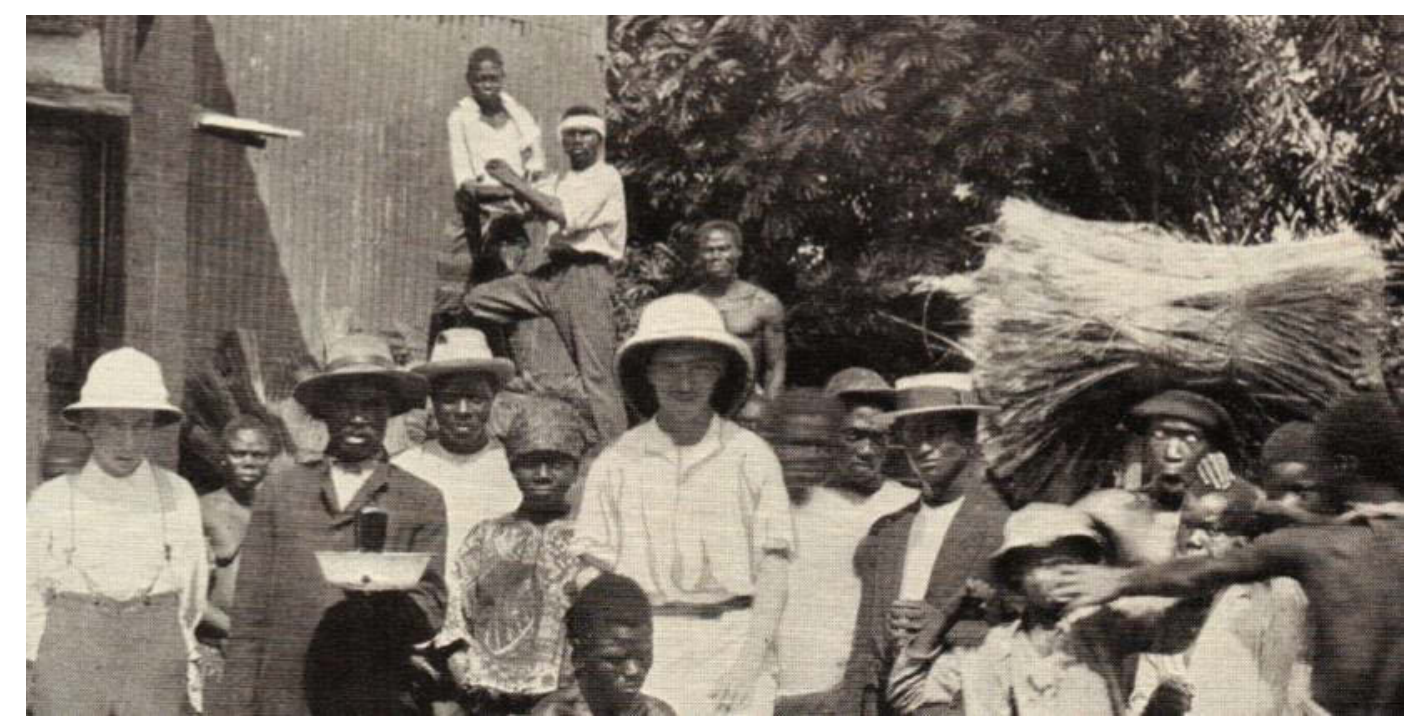

Figure 4 Harold Taylor in Monrovia, $1916^{73}$

Taylor does briefly expand on another principal—but less effective-recruiting method, which he says involved an "appeal to the cupidity of an impoverished Chief". Taylor offered a "payment of so much per head" to certain chiefs, who would then proceed to "round up all the young men" who had incurred real or imaginary debts with them - that is principally those young people a chief "suspected of having affairs with his many wives" whom he could thereby customarily fine. Those unable to pay these fines were "hand[ed] over, body and soul" by the chiefs whom Taylor gave a "lavish commission" to. This depended on the person and disposition of a chief. Just as often, Taylor says he would encounter someone like "Chief Nasty Chap" who refused to allow recruiters to get to work amongst his people. "I have met only two with such a mean look in the whole of Africa, and this fellow was both of them." Taylor "wishing to avoid all friction" left the area-the convoy meandered and leaked. Almost a third of the convoy deserted, no one was being chained or escorted. While coercion can be said to have emerged from localized debt relations, the consistency of this release or co-optation only took place via the manoeuvres and ruses prepared by touts.

\footnotetext{
${ }^{73}$ Taylor, Jungle Trader, 86. Captioned 'My Garraway Customers'. Photograph taken adjacent to the British factory-import-export shop where he worked as a hired salesman.
} 


\begin{abstract}
"Within two or three years [of the 1914 treaty] the recruitment of this type of labour became the biggest slave racket of the century in Liberia. Spanish vessels made regular monthly calls and the wretched black cargo herded into the holds with the hatch-covers battened down to prevent their escape. Spanish Agents aboard these ships would seat themselves at a table on deck and pay out seven pounds in English gold for every boy tallied into the holds." "Government officials, and also members of the Senate, used the armed forces of the State to aid them in this traffic, and I have often seen soldiers of the Liberian Frontier Force escorting these 'labourers' to the boats and even going so far as to see them safely aboard." 74
\end{abstract}

The labour treaty with Liberia (1914-1927) brought over a total of 7,268 indentured labourers. The treaty was revoked by Liberia in 1927 but between 1928 and December 1929 a new "private recruiting deal" was made between various Liberian statesmen - headed by the Postmaster-General Samuel Ross and the Vice-President Allen Yancy - and the Barcelona branch of the planter's lobby, the Sindicato Agricola. This final private recruitment deal brought over 2431 workers. ${ }^{75}$ The Sindicato's most important delegate was the notable Fernandino planter Edward Barleycorn, a school friend of then President, Charles D.B. King. Ross and Yancy were also the superintendents of Sinoe and Maryland Counties in Liberia, where most of the labour recruitment was taking place. The well-publicized ILO commission interviewed hundreds of people there and brought to light a sequence of extortions, unpaid road-building programmes, and shock-tactics all aimed at extracting three thousand Liberian braceros for Fernando Pó-and about 10,000 for the Firestone Rubber plantations in Liberia that had only just been set up in 1926. The Sindicato paid Ross and Yancy \$9 "a head". It also paid for "transportation and a bonus of $£ 1,000$ for each 1,500 laborers shipped." While Ross, like Humplmayr and Woerman before him, duly "paid $\$ 2.50$ per head into the Liberian treasury.", 76

\footnotetext{
${ }^{74}$ Taylor, Jungle Trader, 88.

${ }^{75}$ League of Nations, August 1930, 'Report of the International Commission of Enquiry into the Existence of Slavery and Forced Labour in the Republic of Liberia', LON, C.658.M.272, 36; in French Société des Nations, August 1930, 'Commission internationale d'enqutte sur l'existence de l'esclavage et du travail forcé dans la république de Libéria', AGA, C-81/06416; Sundiata, Brothers and Strangers, 81; Sundiata, From Slaving to Neoslavery, 123, 143.

${ }^{76}$ League of Nations, August 1930, 'Report', LON, C.658.M.272; Sundiata, From Slaving to Neoslavery, 143.
} 
As with other constellations of state-led indentured labour, while dispatching its citizens with armed guards to a tortuous work regime and an uncertain fate the Liberian state did always demand them back; if they came back. A famous AfricanAmerican journalist, George Schuyler, remodelled a question and answer session with a bracero who had just returned to Liberia: "Q: Boys go Fernando Poo with you they come back? A. Most no come back, some do. Lot sleep. Spanish mans kill boy-beat him. Other boys come town and tell. Spanish put boys in jail for one year for tell, so they no come back with me." Schuyler also asked him: "Spanish beat much? A. Yes. Beat boy too much. Give two, three month jail all time." $" 77$ The jail was the principal scene of punishment, and as Nnamdi Azikiwe says it was not only a state-backed disciplinary device, but a means to extend the duration of bracero labour on the island: "instead of 'punctual repatriation' Spain devised a subterfuge to prefer a criminal charge against laborers whose contracts are nearing termination, and by imprisoning them, it derives an unjust benefit from free convict labor.",78

\subsection{Touts and Despot Supplant Each Other in Rio Muni, 1900-1930s}

Spanish Guinea, including Rio Muni, was about a quarter the size of Cuba, or the surface area of Rwanda, Haiti, Wales or the Spanish province of Galicia. Rio Muni had fallen into Spanish hands only at the very beginning of the twentieth century. The 1901 Paris-Treaty - a minor addendum to the Berlin Africa conference-attached its fate to Fernando Pó. As a colonial scientist observed in 1901: "there exists on the coast of Africa a small territory that is now totally the property of Spain. There lives a race called the pamues [Fang], who can substitute those who come from Sierra Leone and Liberia. Let's take care of that tribe called pamue and bring them to Fernando Poo, before others benefit from their labour at our expense." 79 For the first three

\footnotetext{
${ }^{77}$ George Schuyler, 'Wide "Slavery" Persisting in Liberia, Post Reveals', 29 June 1931, New York Evening Post, 1-2. The dialogue continues: "Q. What work boys do in jail? A. Same work as other boys."

${ }^{78}$ Ben N. Azikiwe, 'In Defense of Liberia', The Journal of Negro History 17, 1 (1932): 30-50. The Liberian state also dispatched consuls who "were also to assure the fair treatment of the workers and their safe return." They assured their return by having the bulk of their wages paid out to them only when the braceros disembarked in Cape Palmes.
}

${ }^{79}$ Gutiérrez, 'Guinea Española', 14. 
decades of Spanish rule "in the providential design of colonial policy" Rio Muni was thought of as a "zone that should produce brazos; an appendix to the island." 80

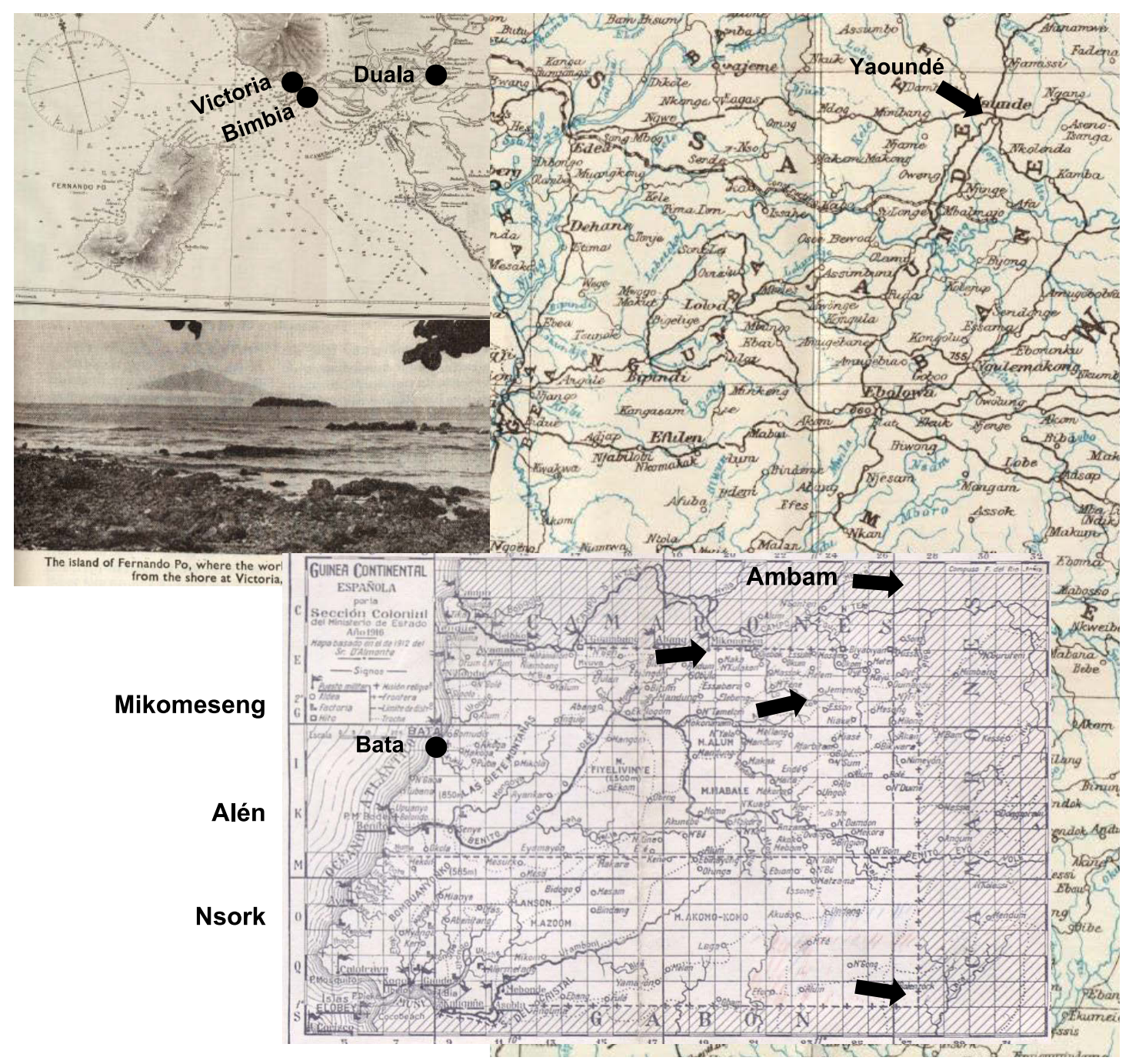

Map 3 Composite of Rio Muni and south-west Cameroon, early 20th century ${ }^{81}$

\footnotetext{
${ }^{80}$ Curaduría (Lasierra), 1930, 'Memoria sobre este servicio', AGA, C-81/07720, L-2; Curaduría (Romain Ordoño) to GG (Domínguez Manresa), 16 July 1931, AGA, C-81/8125, E-2.

${ }^{81}$ Map sources from top left to bottom right. 'Admiralty Chart 1357: River Benin to River Cameroons including the Mouths of the River Kwara or Niger', 1901, TNA, CO 1O47/243; 'Sketch map of Spanish Guinea', in Great Britain, Spanish Guinea, 61; DGMC, 'Guinea Continental Española', 1916, AGA, C-81/06444. Photograph captioned 'The island of Fernando Po, where the work of this District began, photographed from the shore at Victoria, British Cameroons', in Kingdom Overseas (magazine of the Wesleyan Methodist Missionary Society), 2 (1953), 183.
} 
At the turn of the twentieth century, all other European empires had explicitly prohibited recruitment and even labour migration to the sole remnant of equatorial Spanish colonialism. When the international labour boycotts started making a dent in the island's labour supply after 1904, when "braceros stopped coming from Liberia and other African colonies" the planters were "left with our sole continental territory in Rio Muni. It is turning into a breeding ground from where we can extract indigenas to bring to the island" says the Gobernador, Ramos-Izquierdo, the same one who imposed the most brutal round of forced contracts on the island's now almost decimated Bubi population in $1907 .{ }^{82}$ There was a surge in recruitment in 1908 when of the 5600 workers on Fernando Pó, the majority came from Bata and Elobey in southern Rio Muni. This was to fall again; the 1912 census registers only 3000 people from Rio Muni residing on the island. ${ }^{83}$ Nevertheless this was still the largest group of labour. In 1925, there were 3,200 Fang braceros on the island who were "divided among 59 employers"- about as many as there were Liberians. ${ }^{84}$ The specific origin of the braceros was correlated only to the onward march and intensity of activity around the string of border outposts and detachments of an occupying colonial force in Rio Muni. ${ }^{85}$

\footnotetext{
${ }^{82}$ Ramos-Izquierdo and Navarro, Descripción geográfica, 257, 260. In the early twentieth century "forced recruitment on the island" was a "disaster", the Bubis rebelled and were devastated. Their numbers had started to plummet after a smallpox epidemic in 1892 and fell to an all-time low of 2200 in 1920 - from at least 35,000 souls little more than half a century previously. The quasi-genocidal catastrophe was marked by Spanish Claretian missionaries and has been unambiguously portrayed in the Spanish-language historiography. Sanz Casas, 'Política colonial y organización del trabajo', 224; Sanz Casas, 'Los finqueros y el uso del trabajo forzado'; García Cantús, 'El trabajo forzado bubi'; Clavero, 'Bioko'. For the demographic decimation of the Bubi see, García Cantús, 'Fernando Poo', 585; Sundiata, From Slaving to Neoslavery, 117. See demographic graph in the Appendix. A missionary says: "we still remember [Spain's] criminal record of how the Bubi were treated and as a consequences of the inhuman treatment, they were decimated." Vicariato Apostolico de Fernando Poo (Padre Ramon Jutgler) to GG (Núñez de Prado), 10 April 1928, AGA, C-81/06418.
}

${ }^{83}$ Sanz Casas, 'Problemas de una agricultura colonial', 298; Ramos-Izquierdo and Navarro, Descripción geográfica, 317.

${ }^{84}$ Sundiata, From Slaving to Neoslavery, 123; Terán, Síntesis geográfica, 67.

${ }^{85}$ Oyono Sa Abegue, 'L'évolution des structures productives', 480-1. In a $\mathrm{PhD}$ from the 1985, Valentin Oyono writes how, quite distinctively, for the first three decades of the twentieth century, with spurts of conquest activity, "as "pacification' unfolded" the state simply brought to the island braceros in whichever way they could. These "consisted of captives (mainly captured Binzima warriors), hostage and, above all, the population in areas under control of the Guardia Colonial who were being conscripted each year to the plantation on the island of Fernando Poo." Binzama were what Balandier calls "warrior associations". Balandier, The Sociology of Black Africa, 133; Fernandez, Bwiti, 54. For 
It was only a generalized policy of forced labour or prestación in the late 1920s that kicked off an unprecedented wave of recruitment in Rio Muni. In 1923 the Cámara Agricola, the sole planters lobby on the island, was still imploring Governor Barrera to organize "the complete and rational occupation, of the 26,000 square kilometres of Guinea Continental, with which we will undoubtedly achieve a solution, even if partial one, of the problema bracero." ${ }^{\prime 6}$ Planters on Fernando Pó were keen because the costs of Liberian braceros had become "onerous", principally because the treaty stipulated expensively imported food rations, such as Spanish rice and stockfish from the North sea. In addition, as for Liberians half of their wages were to be paid in pound sterling, their labour had become about three times as expensive as that of Spanish subjects. 87 "As a result of their protests the first measures were taken" by the Government to centralize recruitment through despotic channel in Rio Muni. ${ }^{88}$ When the Spanish expanded their military presence and reached the border areas with full force in the late 1920s, they were repeating what the German and French regimes had done to the Fang but with a twist; the economic demands of Fernando Pó were the ends of every means. With a twist and a particular intensity, in 1926 there were some 770 members of the Guardia Colonial in Rio Muni-85 Spaniards, with 2 captains, 11 lieutenants, 51 "cabos", 685 African soldiers (mostly from Senegal, Ghana and Cameroon) out of whom 24 were "cabos"-while in 1900 the entire German "Schutztruppe in Cameroon", comprised "40 German officers, 53 NCOs and 900 African mercenaries," from the "Gold Coast and Togoland" ${ }^{89}$

the whole series of revolts and pillaging that required the "constant strengthening of suppression with Tirallieurs" see Xavier Cadet, Histoire Des Fang, Peuple Gabonais (Paris: L'Harmattan, 2009), 901. For details on binzama in and around Nsork see, Nerín, La soberanía española en el Muni, 39.

${ }^{86}$ Sanz Casas, 'Política colonial y organización del trabajo', 224, citing Cámara, 1923, 'Memoria Delegación Camara Fernando Poo', ANC [I could not find the original at the ANC].

${ }^{87}$ Sundiata, From Slaving to Neoslavery, 142.

${ }^{88}$ Cámara (Estrada) to GG (Núñez de Prado), 28 January 1928, AGA, C-81/08096, E-28.

${ }^{89}$ Nerín, La ùltima selva de España, 196; see AGA, C-81/08204, 'Sobre delimitación de fronteras en la Guinea Española continental y la frontera Kamerun.' In 1905 the corresponding figures for the Schutztruppe were 60, 70 and 1150, Stoecker, 'Cameroon 1880-1906', 79. 
The steps of full conquest - full disarmament, total relocation of the entire population onto roads and extensive road-building programmes themselves-were only initiated after a new Gobernador Miguel Núñez de Prado came to power with a mandate to respond with force to a brief interruption in the Liberian labour supply on the western edge of the Gulf of Guinea. ${ }^{90}$ In the autumn months of 1926, some 4,500 braceros and 1,181 accompanying and working women were sent to the island from Rio Muni through the direct intervention and for the immediate profit of members of the Guardia Colonial. ${ }^{91}$ The braceros recruited by the military went only to members of the Cámara. The planters who were not well connected to the completely absent monopoly granted to the Cámara in 1928, relied on an influx of reclutadores (private recruiters) who started traversing the entirety of Rio Muni and beyond. The Cámara even bombarded the Gobernador with "demands that he should force the recruiters [to] allocate to us at least thirty percent of their acquired braceros". ${ }^{92}$ The Cámara had become used to feeding off the workings of the Liberian and the Spanish colonial state, while other planters not linked to them had started sending off their reclutadores to Rio Muni, Cameroon and Gabon. A petition from over a dozen chiefs-both Fang and Ndowe-explain the situation in their own terms: "Ever since Spain took possession of these lands, we have had or seen nothing that brings betterment to this colony. That there is a law established in Brussels by international pathways prohibiting the sale of slaves puzzles us Chiefs, because from the moment that braceros from Liberia stopped coming the Spanish nation has taken up the everyday selling of Spanish subjects, selling us without mercy."93

\footnotetext{
${ }^{90}$ DGMC, 1930, 'Memoria de la historia de Fernando Poo', AGA, C-81/06843, E-5.

${ }^{91}$ These women worked unwaged as cooks and cultivated food plots near plantations. GG (Nùñez de Prado) to DGMC (Jordana), 12 October 1926, AGA, C-81/07646. For indictments against the entire colonial institutional apparatus, see Nerín, La última selva de España, 225.

${ }^{92}$ Cámara (Ligero) to GG (Núñez de Prado), 3 June 1927, AGA, C-81/06415, E-13; Nerín, La última selva de España, 210.

${ }^{93}$ Jefes de Bata to GG (Domínguez Manresa), 8 September 1931, AGA, C-81/08028, E-2. "People are
resentful that the Republic has kept the rulers that perpetrated injustice in the recent past." The writer
of this petition, an educated person form the mission who had possibly been to Spain, related their new
set of demands close to the heart of the new Republican regime: "no schools have been built to benefit
the younglings, also there is no distinction between the European whether they are planters or
reclutadores they are all governing without respect of the state." The reference to "Brussels"
prohibiting slavery is likely the Brussels Act of 1890 convened by hopeful colonial states where "it was
} 
Planters were not only complaining about the rising prices set by the Liberian state, but also that the reclutadores in Rio Muni had become "too expensive". The Cámara attributed this to the fact that "during the previous years, the liberty to recruit has been absolute, causing a competition and an exaggerated rise in prices paid for braceros." In the late 1920s the recruits were being "escorted by the Guardia Colonial so these would not be taken by other [private] reclutadores". Continuous "struggles between recruiters", between touts and despots, had begun to emerge, the former "would steal" future braceros with offers of higher advances - "and with ploys that everyone knows: the phrases 'don't go with these guys, they'll treat you badly and pay you worse' and others in that style." Despots did indeed keep the price down, "the arrangements carried out by Sr. Buiza" the head of the Guardia Colonial, "helped to keep the costs of recruitment to 100 or 150 pesetas" in contrast to the "bill of 250 or 300 pesetas issued by the reclutadores." 95 One Spanish missionary who was himself involved in la recluta - in the capacity of tout "acting merely as a transmitting station" by "offering a series of goods" beforehand- "passed by a gathering of reclutados [those recruited] in Mikomeseng whose fate was to be sent to the campos [fields] of Fernando Poo. The guards kept saying they were free, that they were only keeping an eye over them," so no other recruiters "could snap them away." $\mathrm{He}$ lamented the consequences for private reclutadores: "some braceros had already agreed to contracts with other employers, but fearing reprisals of the Guardia Colonial they could say nothing." Many of those escorted escaped "and signed contracts for companies they were not destined to," these were the employers who brandished ever higher regalos or advances. ${ }^{96}$

specifically imposed as a duty on the European powers" to "stamp out the evils of slavery and slavetrading in West Africa." Fage, 'Slavery and the Slave Trade in the Context of West African History', 393.

${ }^{94}$ Cámara (Estrada) to GG (Núñez de Prado), 28 January 1928, AGA, C-81/08096, E-28.

${ }^{95}$ Armando Ligero, 11 August 1931, 'Declaración', in DGMC, 'Información', AGA, C-81/06418; Jose Ligero, Barcelona to Delegación en España de la Cámara Agricola Oficial de Fernando Poo, 21 December 1925, ANCB, Fons 237, Caja 1. [Jose was the brother of Armando]

${ }^{96}$ Padre Leoncio Fernandez Galillea, 6 August 1931, 'Declaración', in DGMC, 'Información', AGA, C$81 / 06418$. 
When the dictatorship of Primo de Rivera fell in early 1930, a handful of staffers at the Spanish Colonial Office sent someone to investigate the widely circulating rumour, that the "recluta de braceros in our colony has become a market, with an 800 peseta price tag for the unit HUMAN". The aims of Julian La Sierra, the chief investigator of the Información encaminada a averiguar la forma en que se efectua la recluta de braceros en la Guinea Española-was to determine the extent of the involvement and corruption of members of the Guardia Colonial and the administration. He interviewed practically every European resident in Rio Muni, and a handful of African teachers and chiefs, producing a dossier of over 500 investigative pages. La Sierra was shocked by his own conclusion: "pretty much everyone was involved", "absolutely everyone has been gripped by this fever". He was only "halfjoking [when he said] that la recluta has become a deranged desire, as it has even come to take over the activities of the missionaries of the Sagrado Corazon de Maria". After "perusing the case files" he gathered, La Sierra writes: it is "clear" that the "this activity is not monopolized by anyone. Exactly the opposite is the case, la recluta is in the hands of approximately a hundred trotamundos", globetrotters who "recorren libremente el bosque con todo el bagaje de sus habilidades y artilugios""freely traverse the forest only with the baggage of their know-how and contraptions". 97

Writing in the 1931, another observer on site noted that while "there are some 'monrovias' left", "today the entirety of the human resources working on the island are being imported from the continente [Rio Muni], the immense majority of the braceros on the island's plantations are 'pamues' [Fang]." 98 By the early 1930s they had almost all been brought by a "body of recruiters, technically clandestine but

\footnotetext{
${ }^{97}$ Julian La Sierra Luis, 30 August 1930, in DGMC, September 1930, 'Información', AGA, C$81 / 06418$, E-1. In his defence the head missionary of Nkue, the biggest missionary outpost in the interior said: "we only do a campaign for our plantations, employing no material or spiritual violence whatsoever" and "we pass them on in a state of total liberty to Casa Mallo", a very prominent planter who did much to support the missions' activities. Rdo. Padre Leoncio Fernandez Galilea, 6 August 1931, 'Declaración', in DGMC, 'Información', AGA, C-81/06418. La Sierra's writes simple that the "greed for easy profits has been awakened [in all] and enlivened by the lavish and boastful premiums paid out by the demand side", the planters.

${ }^{98}$ Emilio Carles, Misioneros, negreros y esclavos: Notas de un viaje a Fernando Poo (Valencia: Cuadernos de Cultura, 1932), 33.
} 
perfectly known, who replaced the rulers of Liberia, and turned Cameroun and Gabon into their field of operations." $" 99$ A type of frontier capitalist, the reclutadores were "taking advantage of the scarcity crisis of their product" the braceros; they "made a business out of speculating" with labour before it produced any cocoa. ${ }^{100}$ The cacao planters had been shovelling about half of their profits back into enlisting a new round of braceros. Writing in 1937 after the peak of la recluta in Rio Muni, a Francoist official writes that some " 15.000 workers [had] been recruited in the last seven years, with the commission averaging 400 pesetas, a sum of at least 6 million pesetas has been paid out in the slaving industry of the reclutadores." 101 This is an underestimation, as already in 1930 some 5000 bracero contracts were made in Bata, 4000 of them with the island as their destination. ${ }^{102}$ Almost all of them were misled outright by for example being "promised work in the plantations of Cunha Lisboa" an extremely large and notable Fernandino from São Tomé who was "famed for the good treatment of his labourers" They of course always ending up elsewhere. ${ }^{103}$ The first contract was always uncertain, recruits could never be sure they would end up where promised, and even then an apparent destination matching description could be tenuous and reversible, as was the case with Ebosogo Esono, who was underage and therefore signed up to "housework duties but [was] instead met by a master [Francisco Perez] who turned me from a servant into a bracero."104

It was only because of this contractual bind that the speculation and bidding wars for braceros could take hold. The commission paid by the cacao planters in Fernando Pó to the reclutadores rose from 50 pesetas in 1926 to up to 500 to 800 in the early

\footnotetext{
${ }^{99} \mathrm{GG}$ (Sánchez Guerra) to DGMC (Alvarez-Buylla), 28 December 1935, AGA, C-81/06867, E-5.

${ }^{100}$ Cámara (Avendano) to GG (Manresa), 8 August 1931, C-81/06415, E-2.

${ }^{101}$ Antonio Babiloni Navarro, 1 January 1937, 'Los territorios españoles del Golfo de Guinea vistos por un colono al terminar el año 1936, Libro Segundo’, AGA, C-81/12427.
}

\footnotetext{
${ }^{102}$ Cámara Bata (del Pozo) to GG (Manresa), 11 August 1931, AGA, C-81/8095, E-17. The "ceaseless and large shipments of braceros for the island" came at the expense of planters in Rio Muni as their "needs for braceros [were] not actually inferior to those of the island."

${ }^{103}$ Curaduría (González Ordóñez) to Comisario de la Republica, 26 August 1931, AGA, C-81/06418.

${ }^{104}$ Ebosogo Esono, in Curaduría (Guellin) to GG (Lluesma), 18 May 1934, AGA, C-81/08126, E-19.
} 
1930s. ${ }^{105}$ As a reclutador was overheard saying in a beach bar in Bata, "there is no labour scarcity, the only thing one needs if one wants braceros are pesetas." 106 Considering that the average income for Europeans was 500 pesetas a month, that "margin of profit actively sustain[ed] a large army of intermediaries, direct and indirect, who by all possible means made sure they directed the workers to ensure the best agricultural interests of the island." 107 Scandalized contemporaries thought it was important to note that the "guerrilla of reclutadores and ganchos, [had] jacked up the prices to such exaggerated heights, that we are no longer talking about a compensation for the ordinary costs of recluta but of the PRICE FOR THE SALE OF A MERCHANDISE CALLED 'MAN'.”108

The commissions caused a generalized backlash against reclutadores from the side of the administration and even the planters: "when all this talk of immorality is heard, what is alluded to tacitly is only this high price". To a more cynical Republican labour officer, it was "the fact that the recruiters have jacked up the price of cacao production which lays behind the uproar". ${ }^{109}$ From on high, in the almost wholly uninvolved Republican Colonial Office in Madrid, the recruiters were viewed as "slave-traders, they are completely demoralizing the place, by both mistreating the indigenas and exploiting the employers. They are all undesirables, who in addition dedicate themselves to contraband, the sale of alcohol, and all sorts of disgraceful trades."110 The reclutadores "laden with brandy, whisky, cloths and Virginia tobacco" always had "at least two or three ganchos, African subcontractors from the coast, who strategically camp out in the border villages." 111 Ganchos tended to settle and move

\footnotetext{
${ }^{105}$ Bauer Herbert, 21 August 1930, 'Manifestación', in DGMC, 'Información', AGA, C-81/06418, E-1.

${ }^{106}$ Leonardo Rubio, 21 August 1930, 'Manifestación', in DGMC, 'Información', AGA, C-81/06418, E1.

${ }^{107}$ Cámara Bata (del Pozo) to GG (Manresa), 11 August 1931, AGA, C-81/8095, E-17.

${ }^{108}$ Curaduría (Lasierra), 1930, 'Memoria sobre este servicio', AGA, C-81/07720, L-2.

${ }^{109}$ Curaduría (Romain Ordoño) to GG (Domínguez Manresa), 16 July 1931, AGA, C-81/8125, E-2.

${ }^{110}$ DGMC (Forns Quadra), 13 June 1934, AMAE, R887, E-52.

${ }^{111}$ Babiloni Navarro, 'Los territorios españoles', AGA, C-81/12427.
} 
around "along the border in the towns that have a direct communication to the French side, because it is very much easier to recruit there". Innocently, a Portuguese gancho, a true tout, Juan Ferreira, who spoke Fang, says he "only offered work in Bata to anybody he saw", "convincing them that [ALENA a forestry company on the coast] will always treats its people well" - an outright deception, as they were almost all brought to the island. "Those who sign up I give them some presents in goods and organize their meals until I deliver them." 112

French officials spoke from across the border of "Spanish employers, using methods of the slave-trade rather than 'recruitment"'. However, accompanying this "plague" of reclutadores was not so much the mute violence of fairs or caravans, but a risky and negotiated range of transactions with varying outcomes. In the early 1930s the French started "expanding their surveillance of clandestine recruiters who have installed themselves on our border"-recruiters "of doubtful moral character, who are well known amongst all the chiefs of the Ambam subdivision." 113 A Spanish recruiter crossed into Cameroon "looking for 350 people, so he set up a campaign all along the border with an entire team of rabatteurs"-touts or stalkers. However, possibly because of his reputation, he "didn't manage to recruit anyone [and] lost his onerous baits, the pricey lures, the advances deposited with his agents" or ganchos. ${ }^{114}$ Maurice Mveng noted that already in 1927, 4000 Cameroonians left for Fernando Pó over the land border to Rio Muni. In almost a single year, between 1929 and 1930, the circunscripción of Kribi in south-western Cameroon lost $25 \%$ of its population,

\footnotetext{
${ }^{112}$ Juan Ferreria, 20 August 1932, 'Declaración; Denuncia de Ernesto Ruiz Tejero contra Portuguese Juan Ferreira', AGA, C-81/08028, E-7. The Spanish investigator in this case arrested them all "to get to the bottom of it, of how these individuals proceed, with their illegal means, on the basis of deception and lies, which causes so much damage" to the long-term sustainability of the recruitment economy in Rio Muni.

${ }^{113}$ Chef de la Subdivision Ambam to Chef de Circonscription, Ebolowa, 21 September 1931, ANC, APA, 10165/A. Ayala was "chief and the most active propagandist" of the "most active" "germanophile band" of reclutadores. His associates "old comrades" of the Colonial Guard, such as as "the mulatre Bingua [Bengoa]", and another notorious German, "Kreshmann", were a "notorious", and "always suspect" crew, and Ayala himself singled out as "humourless and villainous character - he's an absolutely shameless recruiter". Chef de la Subdivision Ambam to Chef de Circonscription, Ebolowa, 1 August 1934, ANC, APA, 10165/A.

${ }^{114}$ Chef de la Subdivision Ambam to Chef de Circonscription, Ebolowa, 11 February 1935, 'Nyabessan: Emigration clandestine', ANC, APA, 10165/C.
} 
principally to Spanish Guinea. ${ }^{115}$ Figures are hard to come by, as the "movement was clandestine", but it was estimating that in the early 1930s the Woleu-Ntem province "lost in just a few years many thousands of individuals at the prime of their life." Sautter observes that goods were $75 \%$ cheaper in Bata than in Gabon, and "all pressure, all deception aside, the [reduced prices] in the Spanish territories exerted an attraction on a people for whom the system of bride wealth absorbs large quantity of goods and money."116

To their credit, the Republicans did actually put a halt —if provisional and belated — to prestación (between 1931 and 1934) as well as to la recluta in 1935 through a series of very radical and sweeping reforms. They began by "sanctioning the reclutadores who deploy illegal means and deceit to force the indigena to sign a contract"-and by "giving jail sentences to ganchos." ${ }^{117}$ By 1934 the Republicans came up with various schemes to try to import indentured labour from Cameroon under a treaty in order to "eliminate the reclutadores altogether," hoping that "this would lead to the automatically disappearance of this social class, that stain, the reclutador, that has been an insurmountable obstacle to our colonization." 118 Insurmountable because, as another functionary confirms in 1936: "La recluta has been the most repugnant undertaking of Europeans here in Africa, almost the entirety of the whites here in Guinea have been."119

The Republican Gobernador in 1935, Ángel Manzaneque prepared a reformist peak on a logarithmic scale and set out to change this "status quo in our colony, which has always been run under a total state of exception". Manzaneque disbanded the recruiters and organized instead bolsas de trabajo housed in government buildings

\footnotetext{
${ }^{115}$ Mveng, 'Note sur emigration des Camerounais ä Fernando Po', 37; Nerín, La última selva de España, 229. The total sum of advances, wages and rations under Spanish employers was almost twice as high as the wages for qualified administrative staff, such as clerks and translators in Cameroon.

${ }^{116}$ Sautter, 'Les paysans noirs du Gabon Septentrional', 129, 145.

${ }^{117}$ Curaduría (Guillen), 1934, 'Medidas conducentes al buen exito del tratado de braceros convenidos con el Camerun frances', AGA, C-81/8125, E-2.

${ }^{118} \mathrm{GG}$ (Lluesma) to DGMC (Álvarez-Buylla), 18 September 1933, AGA, C-81/06867, E-5.

${ }^{119}$ Pozanco, Guinea mártir, 86.
} 
which anyone could 'freely' approach without regalos or recruiters. The Governor proudly reported back to his superiors: "I have had to battle hard for this new regime of labour, everyone one was opposed, well they saw in it the death of la recluta, and of misrule, but I have managed to come out triumphant [...] they now recognize the need to live within the law." 120 This Republican experiment was withdrawn, as "free labour [was] to be established, always and only if and when it does not cause a loss to our Treasury". ${ }^{121}$ The bolsas that might have directed people for Fernando Pó lay abandoned; the "bolsas cannot furnish an intense yield, unless they are surrounded by a number of elements that serve as links between the [employers] and the unemployed indigenas - those who can be turned into braceros." ${ }^{122}$ The linkages needed to connect the bracero were disarticulated-ganchos had been jailed, and the commissions and advances had been stamped out with extraordinary fines of thousands of pesetas. ${ }^{123}$ Also as most reclutadores had been staunch Republicans they were executed or fled Rio Muni for Cameroon in 1936 at the beginning of the Spanish Civil War. ${ }^{124}$

The Republicans could foresee that the "completely ineffective system" of bolsas was "bound to degenerate into a more or less manifest recluta with even more vices taking hold because la recluta is being pushed underground, plunging us back into our recent history." 125 Yet the Republicans were steadfast in their decision to have abolished and supressed la recluta. As the last Republican labour officer says in his final report on the matter, "to allow la recluta again is so monstrously immoral and counter-

\footnotetext{
${ }^{120} \mathrm{GG}$ (Manzaneque) to DGMC (Alvarez-Buylla), 24 May 1935, AGA, C-81/06867, E-7.

${ }^{121}$ DGMC (Nombela), 9 May 1935, ‘Orden autorizando proroga contratos', AGA, C-81/08126, E-1.

${ }^{122}$ Cámara Bata to SubGG (Calzada), 4 April 1938, 'Proyecto de ordenación de gestiones para captación y aplicación de braceros destinado a las firmas patronales de la Guinea Continental', AGA, C-81/08126, E-1.
}

${ }^{123}$ Curaduría (Guillen), 1934, 'Medidas conducentes al buen exito del tratado de braceros convenidos con el Camerún frances’, AGA, C-81/8125, E-2.

\footnotetext{
${ }^{124}$ Pozanco, Guinea mártir, 197; Nerín, Un guardia civil; Nerín, 'Y el cabo Nacarino', 199.

${ }^{125}$ Arizcun Carrera, and Martínez y de Pons, Memoria sobre los territorios españoles del Golfo de Guinea, 96; Same quote in DGMC (Canovas) to GG (de Sostoa), 4 June 1932, AGA, C-81/08099, E15 , also in C-81/06415, E-2.
} 
productive for our colonizing action that we shouldn't consider it even for one second." 126 This report was stored away in a box when the Francoist took over-the box was eventually shipped off to Spain and has remained unindexed and opened only once ever since.

During the Civil War years, the planters on Fernando Pó started to panic, they were "feeling profoundly the falta de brazos." "Once they [Fang braceros] finish their contracts practically all of them return to their country, and no new recruits are taking their place." ${ }^{127}$ Already in 1936 the planters in Fernando Pó had quickly shifted to rely on an almost entirely new set of recruiters. As an undercover Nigerian police officer on Fernando Pó says in 1936: "Boys are very difficult to get over here for the Spanish Subjects at Bata had completely refused to come over here at Santa Isabel [so] now the Spanish Farmers being in difficulty to get boys did all they could and so seduced the Nigerian traders especially the Calabarians to begin to recruit boys"; on familiar terms "for each boy recruited the Spanish Farmer pays the sum of three hundred pesetas". ${ }^{128}$ By 1939 the planters on Fernando Pó had become "convinced that the only rapid and viable solution is an intense work of propaganda in Nigeria, which unlike us, has been spared an anxious lack of labour, and therefore we shall not fear that our efforts will be frustrated." ${ }^{129}$ As the Curador in Santa Isabel told the logging lobby in 1940: "if the current arrangement" with Nigerian recruiters "continues (and we expect that it will) we will be able to send you [the employers in Rio Muni] 400 to 500 braceros a month, and if this doesn't resolve the problema

\footnotetext{
${ }^{126}$ Curaduría (Guixeres) to GG (Sánchez Guerra), 24 April 1936, 'Informe sobre el problema de braceros', AGA, C-81/09010.

${ }^{127}$ Cámara to GG (de Mendívil), 1 April 1937, C-81/08129, E-2.

${ }^{128} \mathrm{~S}$. Muyiwa to The Commissioner of Police, Calabar, 24 May 1936, NAE, CALPROF 5/1/194.

${ }^{129}$ SubGG (Cabrera) to GG (Fontán), 2 August 1939, AGA, C-81/09017, E-18.
} 
absolutely, well it's pretty damn close." ${ }^{130}$ Francoist Governors were resolute partisans of what the Spanish liked to call the "external" or the "Nigerian solution". ${ }^{131}$

\subsection{Figures in West and Southern African Colonial History}

During the three decades of colonial rule by Francoist Spain, Fernando Pó became draped in a patchwork of ever-larger plantations. "Two thirds of the surface" cascading down West Africa's largest island, which Livingstone had called an "unpolished jewel", had been studded with an agro-capitalist crown, "transformed into an immense square", its shape on older maps, "where every square meter has been put to use." 132 Cacao exports were being lavishly subsidized by an "autarkic system beloved of fascist ideologues"-since the 1920s all planters and commercial houses had been assured a buyout at almost thrice and latter twice the global market rate. ${ }^{133}$ From just a few hundred-largely Fernandino - planters at the turn of the century, by the final decade of colonial rule there were about 2000 planters. The "number of plantations and farms is unclear, there are a few thousand for sure. These are very diverse, form the 10,000 hectares of INASA [a Spanish corporate plantation with numerous patios] to ones with only 3 or 4 hectares belonging to [African] farmers." By the final years of colonial rule some 90,000 hectares had been planted with coffee and cacao- $-97 \%$ of the island's arable flat surface. With "approximately 60 to 80 braceros required for every 100 hectares" there were necessarily at least 50

\footnotetext{
${ }^{130}$ Curaduría (Carrillo) to GG (Fontán), 6 November 1940, AGA, C-81/08156, E-4.

131"It is our misfortune that our colony has become depopulated, according to the latest calculations we have only 150,000 souls left." "Does anyone think we can extract the fifty thousand braceros that the island needs to reach full production, plus so and so many more thousands for the needs of the planters in the Continente [Rio Muni]? Obviously no. As in times past, and present, we will need the braceros to come from other colonies, and in higher numbers than the current homeopathic doses." Bonelli Rubio, 'Geografía económica de la Guinea Española', 200.
}

\footnotetext{
${ }^{132}$ [Newspaper article from Cameroon, n.d. 1957?], 18 June 1957, 'Es traducción de su original, en frances', AGA, C-81/08221, E-1.

${ }^{133}$ William G. Clarence-Smith, 'The Impact of the Spanish Civil War and the Second World War on Portuguese and Spanish Africa', The Journal of African History 26, 4 (1985): 309-26, 309; Jordi Sant Gisbert, 'El modelo económico colonial y sus contradicciones: Fernando Poo (1900-1936)', AfroHispanic Review 28, 2 (2009): 57-80; Jakobeit, 'Prospects for the Cocoa Economy in Equatorial Guinea', 222.
} 
to 70,000 thousand contract workers. ${ }^{134}$ Before independence in 1968 , the island had a population of 100,000 souls, plantation "agriculture in Fernando Poo employed 82\%" of the "active labour force", "out of which 90\%" were Nigerian immigrants "under peonaje contracts". ${ }^{135}$ Even during the final years of colonial rule when there were about 70,000 Nigerians in Spanish Guinea the planters still had not achieved their goals: "the total solution of the problema will never be found. Alas, we will need to find partial solutions by further intensifying out work of captación de braceros", the capturing or recruitment of braceros. ${ }^{136}$

The number of Nigerian contract labourers on Fernando Pó during the beginning of World War II, some 25,000, was equivalent to over ten per cent of Nigeria's entire wage-employed population - and practically all had arrived in the late 1930s through the clandestine channels set up by touts operating out of Calabar. The island had about half the number of those employed in the entire Nigerian civil service-by far the biggest employer in British West Africa. 137 "It might strike one as odd that

\footnotetext{
${ }^{134}$ MAE, 10 March 1962, 'Desarollo de la economía en Fernando Poo', AGA, C-81/13039, E-392. "The total hectares planted with cacao is 47.425; and coffee 39.665 hectares. There are also a few hundred more hectares of a some other crops" such as palm oil and yucca. The figure of contract labour "is reliable for it is known that farmers cannot operate with less than 5 men per hectare and there is a total of approximately 50,000 hectares now [in 1950] under cultivation." British VC (Spencer-Cooke) to Commissioner of Labour, Lagos, 10 October 1950, 'Labour Report for the period 1st of July to 30th September 1950', TNA, FO 371/89597.
}

\footnotetext{
${ }^{135}$ Armin Kobel, 'La République de Guinée Equatoriale: ses ressources potentielles et virtuelles et les possibilités de son développement' (PhD Thesis, Neuchâtel, Université de Neuchâtel, 1976), 494; Emmanuelle Sandinot, 'Guinea Ecuatorial (española): Un territorio del que se habla poco', Cuadernos de Ruedo Iberico 13/14 (1967): 90-105, 104.
}

\footnotetext{
${ }^{136}$ Demetrio Ruiz Benitez, 'Guinea española: economía de la colonia y estudio especial de su comercio exterior', (MA Thesis, Madrid, Escuela Central Superior de Comercio, 1970), 50. Even though "after 1943 the problema had lost some of its intensity" what "appears time and again" also in the Francoist period "is the difficulties in acquiring brazos." René Pélissier, Los territorios españoles de Africa (Madrid: Consejo Superior de Investigaciones Científicas, 1964), 52, 62; Gonzalo Sanz Casas, 'Problemas de una agricultura colonial: Los territorios españoles del Golfo de Guinea, 1940-1960', (MA Thesis, Barcelona, Universidad Autonoma Barcelona, 1975), 292.

${ }^{137}$ Heinrich A. Wieschhoff, Colonial Policies in Africa (Philadelphia: University of Pennsylvania Press, 1944), 38. The figures for Nigeria in 1938 for those employed for wages was 182,600, of which 50,000 each in mines and government, in a Nigerian population of twenty-one million. Orde-Browne, Labour Conditions in West Africa, 79. During the World War II years, the ranks of men looking for an alternative to the forced labour of the Nigerian mineral industries and the war front in Burma grew considerably; Michie, 'Labour Conditions', para. 29; Nigeria, Annual Report of the Department of Labour, Nigeria, for the year 1944. For an academic rewriting of these two reports, see Osuntokun Equatorial Guinea-Nigerian Relations, 36-40. That recruitment for agricultural work in Fernando Pó
} 
Fernando Po should have played such an important role in the history of the economic life of Nigeria." 138 Even in the 1950s, more Nigerians were working Spanish Guinea than the whole of Nigeria's medium to large-scale "Agriculture, Forestry and Fishing” sector which employed 42,680 people. ${ }^{139}$

On a clear day the distant peak of Fernando Pó can be seen from the island of Príncipe. On the same Gulf, at São Tomé between 1902 and 1928 almost exactly 100,000 serviçais or contract workers went to São Tomé—under varying conditions of recruitment - from Angola, Mozambique and Cape Verde. Between 1928 and 1958 another 85,000 serviçais arrived. In 1909 there were some 35,544 serviçais on about 200 roças or plantations, the year São Tomé became the world's largest producer of cocoa (18\%) only for the well-known boycott to kick in. ${ }^{140}$ Fernando Pó had about the same number of braceros as those privately employed with contracts in the whole of French West Africa in 1935. In 1945 European agricultural properties in AOFmainly the coffee, cocoa, palm and banana planters in Ivory Coast and Guinea-only amounted to some 75,000 hectares, about 15,000 less than the total surface area under cultivation in Fernando Pó in the 1960s. ${ }^{141}$

compared favourably with militarized conscription, see Killingray, 'Labour Exploitation for Military Campaigns in British Colonial Africa', 497.

${ }^{138}$ Udoma, The Story of the Ibibio Union, 186.

${ }^{139}$ Central Office of Information, London, December 1959, 'Fact Sheets on the U.K. Dependencies, The Federation of Nigeria', TNA, LAB 43/357. Some of the "principal wage-earning occupation" in 1957 in "undertakings employing ten or more persons", were "Agriculture, Forestry and Fishing, 42,680; Mining, Quarrying, 53, 640; Government, 120,000”.

${ }^{140}$ Their numbers remained high before declining in the post-WWII period to some 20,000 serviçais, by which time they were outnumbered by the islands primary residents, the creole forros, many of from libertos, who had always disdained the idea of "farm work for wages" and rejected plantation labour. Oliveira, A economia de São Tomé, 50; Seibert, Comrades, Clients and Cousins, 50-1; Keese, 'Forced Labour in the "Gorgulho Years", 107; Hammond, Portugal and Africa, 313. On later sources of labour from Mozambique see Nascimento, Desterro e contrato. Only a few hundred tones of cocoa were being produced by large landowners in the 1870s. Eclipsing the many small farmers on the island, Jose Maria de Souza e Almeida was said to be the "cocoa pioneer" in São Tomé. Almieda was born in Principe of a Bahian father and an African mother, and made his "fortune in the Angolan slave trade" before buying up "abandoned estates" in the early 1850s. Clarence-Smith, Cocoa and Chocolate, 158.

${ }^{141}$ Cooper, Decolonization and African Society, 51; These plantations were eventually taken over and far surpassed by peasant producers who drew in a varied labour recruited by various means - including debt pawns, wage labour-both informal and on short-term contracts - and various shifting definition of kinship. Figures for French West Africa are from 1935, total private contracts 22,785, versus those 
Adjacent to Fernando Pó's shores, a little more than a few dozen kilometres across the Bight of Biafra, the large mostly German plantations on the slopes of Mount Cameroon had less hectares planted than Fernando Pó and between 25,000 and 40,000 workers in the late 1930s. About 3000 of them were Nigerian, mostly Igbo. As the next chapter shows, they were brought by the same recruiters as Fernando Pó. Within a decade Igbos' made up the majority of the plantation workforce in Cameroon. ${ }^{142}$ The workers in these plantations "were not contract labourers per se, if they don't show up to work they don't get paid." In early 1950s salaries in the Cameroon were a little higher than the official ones in Fernando Pó. After the war, British managers also handed out a "monthly bonus" of 6 shillings, about 10 percent of the wage, that was paid out only if workers "work over a minimum of 24 days a month." 143 The annual turnover on these plantations was 60 to $70 \%$. Workers were not given advances. Indeed prospective workers themselves had to 'dash' recruiting agents to get a placement: "trying to get work on the plantations [involves] the exorbitant bribery which is nowadays practised to an almost unbelievable extent, [...]

employed without contract 117,803 . There is a certain dearth of literature on plantation in AOF, but see also A. I. Asiwaju, 'Migrations as Revolt: The Example of the Ivory Coast and the Upper Volta before 1945', The Journal of African History 17, 4 (1976): 577-94; On redefinitions of kinship under conditions of cash-crop production, see Cati Coe, 'How Debt Became Care: Child Pawning and Its Transformations in Akuapem, the Gold Coast, 1874-1929', Africa 82, 2 (2012): 287-311; On Yoruba debt peons in West African 'peasant' plantations, see E. Adeniyi Oroge, 'Iwofa: An Historical Survey of the Yoruba Institution of Indenture', African Economic History 14 (1985): 75-106; B. A. Agiri, 'The Development of Wage Labour in Agriculture in Southern Yorubaland 1900-1940', Journal of the Historical Society of Nigeria 12, 1/2 (1983): 95-107; see also Austin 'Cash Crops and Freedom'.

${ }^{142}$ Graf zu Trauttmansdorf, 1942, 'Denkschriften über Arbeits und Sozialrecht, Arbeitseinsatz und Lohnfragen im Britischen und französischen Mandatsgebiet Kamerun und Vorschläge für die Neugestalltung', BArch, R2/4989.

${ }^{143}$ Minutes, 26 August 1953, 'Minutes of the talks about the revision of the Labour Treaty', AGA, C$81 / 12373$, E-392. The labour officer in the minutes says that "the best employment a native of Nigerian can find as a bracero" in Nigeria, "are in the banana, rubber and palm oil plantations, where the monthly salary can reach $£ 3-10-4$ " or some 70 shillings, where at least 3 to 10 shillings would go to their own food costs. Contemporary studies say there was no desertion; if workers were abused they simply did not show up any more, but this did not involve 'breaking' contracts. Ardener et al, Plantation and Village in the Cameroons, 221. This is different of course from the violent and longcontracts of the German period, Ardener and Ardener, Kingdom on Mount Cameroon, 151-62; Though there were minor credit-arrangements for stabilization, see Nigeria, 'Report on the Administration of the Cameroons under British Cameroons for the year 1938', TNA, CO 583/239/5, para. 187-88. "Wages are at daily rates but in order to discourage employees from leaving without adequate notice it is customary to pay them monthly." And since they were not paid it became "general practice" to have workers "paid' provisionally "in the form of credit notes on the plantation's own store." Indeed on some plantations "it is compulsory for employees to take part of their wages in credit notes," usually about " $50 \%$, is paid in this form". See also zu Trauttmansdorf, 'Denkschriften über Arbeits und Sozialrecht', 1942, BArch, R. 2/4989, “Anlage V”. 
any labourers will be required to pay 30 s or $£ 2$ to the foreman as a preliminary to being engaged". And without a continuous show of "occasional "dashes" to the foreman, he "will throw [the labourer] out of the gang and engage another labourer on similar terms." 144 This was the opposite of Fernando Pó, where even the Republicans did not and "could not allow contracts to be terminated prematurely, unless the employer and bracero mutually agree; well otherwise very few braceros would fulfil their entire contract, as the regalos [advances] employers hand out to new recruits would lead the braceros to constantly change employer implying a grave danger for the operation of the island's plantations". ${ }^{145}$

In relation to South Africa, Fernando Pó is of course tiny, but not as tiny as one might think. Apparently, exactly 152,184 indentured labourers from the Bay of Bengal were brought to the sugar plantations in Natal over a fifty-year period until 1911 —on 384 ships from Madras and Calcutta. Over about half the same time-period the total numbers of Nigerians who arrived on Fernando Pó on 'official British indenture' through the bi-monthly steamer of the labour treaty - and excluding the numbers of wholesale canoe-smugglers-was significantly more. Exactly 63,695 Chinese coolies were brought on three-year contracts to the Witwatersrand gold mines between 1904 and $1907 .{ }^{146}$ At any one point in time in the early twentieth century there were at least 175,000 people employed across the South African mines and related activities. In 1905 over 100,000 new contract per year were being made, mostly by the WNLA, the monopoly recruitment branch of Chamber of Mines that operated outside the Transvaal. ${ }^{147}$ Before the Union or the unification of the British South African colonies in 1910, two thirds of labour force in the Transvaal colony's mining industry were from Mozambique - recruited largely channelled through the logistics of 'touts' as I will review in the next chapter. Though already in the late 1910s the miners started

${ }^{144}$ LO Buea (Nwokedi) to Commissioner of Labour Lagos, 5 April 1948, BNA, Qd/a (1947)1; Konings, Labour Resistance in Cameroon, 61.

${ }^{145}$ Curaduría (Guillen) to GG (Lluesma), 28 April 1934, AGA, C-81/08126, E-19.

${ }^{146}$ Meer, Documents of Indentured Labour: Natal, 29; Vahed, 'Power and Resistance: Indentured Labour in Colonial Natal, 1860-1911', 106; Richardson, Chinese Mine Labour in the Transvaal, 204; Kynoch, 'Controlling the Coolies: Chinese Mineworkers and the Struggle for Labor in South Africa'.

${ }^{147}$ MacDonald, 'Colonial Trespassers', 248. 
depending on a more closely regulated channels both closer and further afield, particularly from the Xhosa-speaking Ciskei, Transkei as well as Lesotho. Under the 1928 'Mozambique convention' the WNLA was allowed to recruit between 80,000 and 100,000 Mozambicans per year. The Portuguese authorities received a "capitation fee" of almost $£ 5$ for providing indenture-like channels that prolonged the contract to 12-18 months, reduced their total wages and paid out half of them only on their return to thereby assure their subsequent — and obligatory — 'repatriation' or deportation. ${ }^{148}$ With the comparative and numerical dimensions of Fernando Pó in mind, I will turn now to the archive and to those who made these extraordinary numbers possible.

${ }^{148}$ Coquery-Vidrovitch, 'The Colonial Economy of the former French, Belgian and Portuguese Zones', 464; Wilson, Labour in the South African Gold Mines, 70-1; Jeeves, Migrant Labour in South Africa's Mining Economy, 10. 


\section{Touts and Despots Combine: Panya or the Bonding of Labour with Language}

Today, in Nigeria across various languages, panya (pánà) is the colloquial name for Bioko, formerly Fernando Pó. In West Africa, during the nineteenth century, the noun 'Panyer' meant 'a Spaniard', from the pidgin rendering of España. In Igbo areas, Ugo Nwokeji says, "up to today, the word panya in Igbo folklore refers to forceful removal to the unknown." The same is true in Ibibio, though I would add the important qualification that "force" in panya stresses a series of social and physical forces that keep someone from coming back rather than the act of violent "seizure" which along most of the West Africa in the pre-colonial period was referred to as being panyarred. ${ }^{1}$ Panya and panyarring have different etymologies but there was a mutual layering and transformation of both terms in twentieth century eastern Nigeria, when the meaning of panyarring - the "seizing" of free people "by force or fraud" as used by "both Whites and Blacks" in precolonial Calabar ${ }^{2}$ - was reinterpreted in light of new experiences with the colonial labour market of Fernando Pó. In Southern Nigeria by the early twentieth century panya became a term to refer to various goings-on, and particularly to a range of relationships linking a class of illicit commercial intermediaries with a host of impoverished job-seekers from specific regions in Nigeria. On the Cross River delta in the mid twentieth century, panya was "a term usually used only by smugglers"; it was also a term used to refer to them, connoting

\footnotetext{
${ }^{1}$ Nwokeji, The Slave Trade and Culture in the Bight of Biafra, 127, 131; Nwojeki says that "to panya" is the Igbo verb form of panyarring and links it to "child-stealing" practice of the Aro (personal communication, December 2014). Panyarring has its own pidgin etymology, most likely from the Portuguese word apanhar "to grab" or to "seize", but the term also had a broad valency, as it referred to possession and theft in different contexts, such as spirit possession and 'man-stealing' or anonymous kidnapping. Hans Christian Monrad, Two Views from Christiansborg Castle: A Description of the Guinea Coast and Its Inhabitants (Legon: Sub-Saharan Pub, 2009), 57, 220. Panya was by the twentieth century totally delinked from the most common definition of panyarring, or the slaving practice, present up until the late nineteenth century in various parts of West Africa, of debt-collection or communal retribution that resulted from the break-down of pawnship and the repayment of credit. Olatunji Ojo, “Ėmú” (Àmúyá): The Yoruba Institution of Panyarring or Seizure for Debt', African Economic History 35 (2007): 31-58; Lovejoy, 'Pawnship, Debt, and "Freedom" in Atlantic Africa', 78, 59.

${ }^{2}$ John Ranby, Observations on the Evidence Given Before the Committees of the Privy Council and House of Commons in Support of the Bill for Abolishing the Slave Trade (London: John Stockdale, 1791), 83.
} 
"mischievous" "hustlers". In Igbo areas its meaning was linked to ahia panya or "panya trade" meaning smuggling but also faulty and unsound commodity exchange. ${ }^{3}$ The toponym Panya, in addition to being an actual buying and selling hub for canoedeploying smugglers, was also a popular conceptual plateau, because "no one receives news directly from anyone who goes to [work in] Fernando Po. Rumours of death, imprisonment and ill-treatment are current." ${ }^{4}$ It was a figurative but "hard" place to where "misfits", and troublesome children and subordinates "feared" being sent off to, threats made by superiors usually in a facetious manner. But many people did in fact disappear to panya, and if they came back at all, they returned many years later, more often than not "empty handed" with "nothing to show" in terms of "achievements" and gains - the meaning of the expression "having come back from panya". ${ }^{5}$ Panya was a layered and localized reflection of the violence and language of capitalism in an imperial labour market in West Africa — of the experiences of commodified mobilities and the opaque commercial mediators of those mobilities. This chapter is an exploration of panya labour recruitment techniques or the informally arranged crossborder migration of Nigerians to Fernando Pó.

An account of the pattern and effectivity of its trajectories is important not only because this migration is one of the largest in colonial African history. If in 1938 the “influx of Nigerian boys into Fernando Po" was "undoubtedly on the increase", a year later recruiters operating out of the eastern Nigeria had brought over an unprecedented and never again surpassed "12000 Nigerian labourers and all of them were smuggled in canoes across the sea". ${ }^{6}$ Illegal migration peaked during the rough

\footnotetext{
${ }^{3 ‘}$ 'Smuggling - Nigeria’s curse', Drum, Lagos, January 1961; Donald C. Simmons, 'Analysis of the Reflection of Culture in Efik Folktales' (PhD Thesis, Yale University, 1957), 26; Datguru, 'Where Is PANYA In Nigeria?', \#airaland Forum, 1 July 2014, <http://www.nairaland.com/1794650/wherepanya-nigeria>; E. Nolue Emenanjo, 'Slangs and Colloquialisms in Modern Igbo: A Preliminary SocioLinguistic Study', Ikenga: Journal of African Studies 4, 2 (1980): 49-65, 52.

${ }^{4}$ Governor of Nigeria, Lagos to British Consul-General, Duala, 16 January 1945, NAE, CALPROF $17 / 1 / 277$.

${ }^{5}$ Felix K. Ekechi, Pioneer, Patriot, and Nigerian Nationalist: A Biography of the Reverend M.D. Opara, 1915-1965 (Durham: Carolina Academic Press, 2010), 60, 261.

${ }^{6}$ British VC (Twigge-Molecey) to Resident, Calabar, 30 November 1938, NAE, CALPROF, 5/1/194; Supt. of Police, Calabar to Commissioner of Police, Lagos, 30 December 1938, NAE, CALPROF 5/1/194; 'Fernando Po Labour Conditions', The Nigerian Daily Times, Lagos, 13 July 1939.
} 
war-decade, spanning the Spanish Civil War and World War II, during these years contemporaries spoke of workers being "virtually 'press-ganged' for Fernando Po".? As David Pratten has observed, "fears" of a "revival of the slave trade" developed "on a new axis during the 1930s with the dramatic increase in migration of Nigerian workers [to] Fernando Po off the coast of Calabar." 8 The idea of "revival" is relayed not only allegorically and polemically in the only two existing empirical academic works, both Henderson Tapela and Akinjide Osuntokun speak of a twentieth century "Nigeria-Fernando Po 'middle passage"". ${ }^{9}$ Early in 1939 Okon Archibong, a future anti-colonial political activist, let the chief provincial administrator at Calabar know of the "unrest that is existing in your Province" due to the revival of "a slavish act [that] had been absent from this Province for many years". ${ }^{10}$ British district officers throughout the Eastern Provinces had been receiving many "complaints asking for information as to absent relatives in the island and alleging "slave dealing". To the families and clan chiefs it seemed obvious where to point fingers, the "recruiting of labour is largely carried out by the Efiks and people living in the area of the Cross River estuary". ${ }^{11}$ Recruiters were a small group of emerging professional traders. An undercover Nigerian police officer in Fernando Pó, S. Muyiwa, writing in 1936 was appalled by "the inducement that the Spanish Farmers offered these recruiters," which had caused a few "Ibo and Calabarian traders"-journeying and trading legitimately on the steamers to Fernando Pó throughout the early 1930s - to "totally abandon their good trade of local food-stuffs and this cling to shipping of human cargos into Fernando Poo"- "these dealers in slavery now believe or this take this traffic to be the means of living." 12

\footnotetext{
${ }^{7}$ Nigeria over the Water', West Africa, London, 1 January 1958.

${ }^{8}$ David Pratten, The Man-Leopard Murders: History and Society in Colonial Nigeria (Edinburgh: Edinburgh University Press, 2007), 165.

${ }^{9}$ Henderson M. Tapela, 'Nigerian Labour for Fernando Po', The Calabar Historical Journal 3, 1 (1985): 36-56, 51; Osuntokun, Equatorial Guinea Nigerian Relations, 40.

${ }^{10}$ O. Archibong to Resident, Calabar, 23 January 1939, NAE, CALPROF 5/1/194.

${ }^{11}$ DO Uyo to Resident, Calabar, 11 January 1939, NAE, CALPROF 5/1/194.

${ }^{12}$ S. Muyiwa to Commissioner of Police, Calabar, 24 May 1936, NAE, CALPROF 5/1/194.
} 
Panya labour smuggling was portrayed differently by those who experienced it on the one hand, and on the other, by their family members, by literate members of vocal public, and by the British colonial administration. For the latter the "traffic of labour to the Spanish Guinea falls little short of "blackbirding." 13 In the early 1950s a British Vice Consul on the island says "for the last fifteen years and even before that" Fernando Pó was seen "as a source of income by [those] who enriched themselves by shangaing unsuspecting Eastern Nigerians over here and selling them as labourers". ${ }^{4}$ "Blackbirding" and "shanghaiing" were terms for a modality of recruitment in the nineteenth century colonial Atlantic and Pacific that meant kidnapping for remote offshore indentures on board ships or in plantation islands and enclaves. This modality usually operated outside affidavit-generating courts and controlled contract-making bodies in 'home' countries, instead contracts were almost always forced onto people at the final destination, and the destination itself was usually unclear, or when it was known, recruits were "seriously misled by unscrupulous recruiters" about their “duties, and compensation". ${ }^{15}$ In the 1930s Major Orde-Browne, a prolific advisor on African labour matters to the British colonial secretary, says the principal feature of recruitment for Fernando Pó's was characterized by "native touts who deceive" migrant workers "as to the nature and conditions of the work". Uncertain as to what these tangles of (mis)information would mean for the character of this movement, he concluded that the "decoying of labourers out of [Nigeria] may well be little short of slavery." In light of the numbers of Nigerians going to Fernando Pó, Orde-Browne ended up assuming that the "majority of people seeking work are probably doing so voluntarily", because of the fact that practically no one who went to panya, considered themselves a slave or enslaved at the point of recruitment. His hesitation

\footnotetext{
${ }^{13}$ Minister of Economic Warfare, Special Operations Executive (Simpson), to Commissioner of Labour, Lagos, 20 December 1942, 'Final Report on Fernando Po and Spanish Guinea, 1942-1943', TNA, HS $3 / 77$. ${ }^{14}$ British VC and LO (Bradley) to Commissioner of Labour, Lagos, 2 April 1952, 'Annual Report
covering the period 1st of April, $1951-31$ st March, 1952', TNA, 371/96714.

${ }^{15}$ Northrup, Indentured Labor in the Age of Imperialism, 6.
} 
on both fronts_- "little short" and "probably" - is symptomatic of the double bind of this 'free and unfree' labour movement. ${ }^{16}$

In the wider literature on unfree labour the "duplicitous inducements of indentured servitude" is sometimes analytically placed uneasily alongside imperial naval impressment surges and even the panyarring techniques of the West African slave trade. ${ }^{17}$ Marina Carter puts indenture somewhere in the middle of the spectrum but closer to one end; she argues that recruitment in the Bay of Bengal for Mauritius was "closer to white indentured servitude than to the system of slavery which had immediately preceded it". Mauritius has the title of being the "largest recipient of indentured labour [within] the British Empire." "Almost half a million Indians" were brought to this island in the Indian Ocean from the 1840 s on. ${ }^{18}$ Carter makes the analogy to "white indentured servitude", because it is assumed that in both constellations the British state stamped contracts before departure and that it had a hand in supervising contracts, as well as orchestrating the passages and preparing specialized ships. In the port towns of the Bay of Bengal this was often the case, in the "early attempts at indenture, private companies were given almost complete freedom to recruit in India, required only to take potential migrants before a local magistrate who would assure that they were departing voluntarily." 19 If the destination was known and consented to then it would seem that indentured labour can lean on the freer side of the spectrum. But how did those recruited experience this procedure? The routes to Trinidad, Guyana, Mauritius, Fiji, Guyana and Assam were largely paved by private Bengali recruiters, the arkatis who "worked in bazaar towns and

\footnotetext{
${ }^{16}$ Orde-Browne, Labour Conditions in West Africa, 47, 71.

${ }^{17}$ Niklas Frykman, 'Impressment, Kidnapping, and Panyarring', in The Princeton Companion to Atlantic History, ed. Joseph C. Miller (Princeton: Princeton University Press, 2015), 240-42, 242; Peter Linebaugh and Marcus Rediker, The Many-Headed Hydra: Sailors, Slaves, Commoners, and the Hidden History of the Revolutionary Atlantic (New York: Verso, 2000), 133.
}

${ }^{18}$ Carter, 'Strategies of Labour Mobilisation', 243; Marina Carter, 'The Transition from Slave to Indentured Labour in Mauritius', in The Wages of Slavery: From Chattel Slavery to Wage Labour in Africa, the Carribbean, and England, ed. Michael Twaddle (London: Frank Cass, 1993), 115-36, 117; Allen, Slaves, Freedmen and Indentured Laborers in Colonial Mauritius, 59.

${ }^{19}$ McKeown, Melancholy Order, 72. 
pilgrimage centres, attracting individuals who were in transit [or] looking for work." 20 Arkatis developed a particularly unsavoury reputation. In the folkloric songs forged and recited by coolies in the Assam tea plantations in the late nineteenth century, arkatis are transposed and named as a trickster; Shyam/Jaduram. As Nitin Varma says of the narrative, it is the recruiters who carves the "path to the sites of "oppression", who through "deception (Phanki") "lured them to contract (Paka khata) and facilitated their passage to Assam". The song goes: "Putting my name down in the (Contract) Oh nasty Shyam" "You deceived me to Assam" "Oh Jaduram You deceived us to Assam". "We saw the sky in Hooghly and thought we were going to Assam to pull pankhas but instead we were given spades by the sahibs to work." "Alas crafty Jaduram, you have deceived me and sent me to Assam by false promise." 21 These professional contractors were seen as purely commercial agents "who traded in labour for profit, thereby approximating 'traffic' in persons". They were the "dominant mode of labour mobilization in the 1860 s" and were eventually accompanied by a formalization with "increasingly elaborate state regulation and corporate recruiting" schemes and monopolies. ${ }^{22}$

An earlier generation of "white indentured servants" had similar experiences. Historians of "white indentured servants" in the early modern British empire have empirically revised the classic accounts and imaginaries of the so-called "freewillers"-of restless freedom and greener pastures - to show how the "majority of

\footnotetext{
${ }^{20}$ Oddvar Hollup, 'Kinship and Marriage in the Construction of Identity and Group Boundaries among Indians in Mauritius', in Culture, Creation, and Procreation: Concepts of Kinship in South Asian Practice, ed. Monika Böck and Aparna Rao (Berghahn Books, 2000), 219-43, 229; John D. Kelly, "“Coolie" as a Labour Commodity: Race, Sex, and European Dignity in Colonial Fiji', The Journal of Peasant Studies 19, 3-4 (1992): 246-67.
}

${ }^{21}$ Soumen Sen, Khasi-Jaintia Folklore: Context, Discourse, and History (Chennai: National Folklore Support Centre, 2004), 10; Varma, 'Producing Tea Coolies?', 125-6; see his footnote in page 313 for full references and details of compilers. In Assam "most of the people recruited under the present system have been phuslaoed by the recruiters." India, Proceedings of the Assam Labour Enquiry Committee in the Recruiting and Labour Districts, Vol. I (Evidence) (Calcutta, Government Priner, 1906), 5; Crispin Bates, 'Coerced and Migrant Labourers in India: The Colonial Experience', Edinburgh Papers In South Asian Studies 13 (2000), 22; Gopalan Balachandran, 'Recruitment and Control of Indian Seamen: Calcutta, 1880-1935', International Journal of Maritime History 9, 1 (1997): 1-18; Samita Sen, 'Questions of Consent: Women's Recruitment for Assam Tea Gardens, 1859-1900', Studies in History 18, 2 (2002): 231-60.

${ }^{22}$ Sen, 'Commercial Recruiting and Informal Intermediation', 7. 
indentured servants recruited in London were recruited illicitly, although they were mainly trepanned by the spirits rather than kidnapped by force". ${ }^{23}$ The old and new literature on indenture has provided abundant examples of the creative and fiercely "consistent" ways in which those forced or inclined to sell their labour in a labour market would be "deliberately deceived about their real destination". ${ }^{24}$ I think one should understand "destination" not only as geographic direction, but also as a place in the division of labour, because those who were promised acceptable jobs such as agricultural work in Nigeria, or desirable placements as trading assistants, clerks and drivers whether in Nigeria or Fernando Pó ended up in a type of indentured plantation labour that was alien in Nigeria.

The British colonization of Nigeria was overtly justified not only "to suppress the slave trade" but also "to prevent its revival under the guise of contract labour". ${ }^{25}$ Monica Schuler writes of "the slave trade" continuing "in the guise of indentured labour in areas where slavery had been abolished", being carried out by a class of "agents" who "emerged after the slave-trade" and "who brought colonial indentured labourers, into the same or new plantation zones." Schuler notes that while of course "Europeans recruited some voluntary indentured workers in Africa, most recruits were involuntary, and their acquisition involved deliberate violence, restraint, fraud and purchase." She says that such labour recruitment in Sierra Leone in the 1840s for indentures in British and French Guiana "combined the recruiting techniques of the African slave trade with the old European bond servant traffic". ${ }^{26}$ The Fernando PóNigeria connection during the first half of the twentieth century is quite peculiar because both African recruiters in Nigeria and the Spanish imperial state and a mix of both African and European employers on the island were immune to the interventionism of British humanitarian imperialism. Panya does not fold neatly into

\footnotetext{
${ }^{23}$ John Wareing, "“Violently Taken Away or Cheatingly Duckoyed": The Illicit Recruitment in London of Indentured Servants for the American Colonies, 1645-1718', The London Journal 26, 2 (2001): 1$22,4,6$.

${ }^{24}$ Allen, 'European Slave Trading, Abolitionism, and "New Systems of Slavery", 2.

${ }^{25}$ Robert Smith, 'The Lagos Consulate, 1851-1861: An Outline', The Journal of African History 15, 3 (1974): 393-416, 415.
}

${ }^{26}$ Schuler, 'The Recruitment of African Indentured Labourers', 127. 
the British, French or Portuguese empire based "under the guise of contracts" literature, a term used in African history especially in relation to state-sanctioned indentures, apprenticeships or engage schemes in the post-abolition mid nineteenth century, when many tens of thousands of freed captives or new slaves were signed up after arriving at various port towns in West, Central and East Africa through former slave supply routes. ${ }^{27}$ Fernando Pó was in no way analogous to São Tomé, where up until the early twentieth century, those enslaved in the Bié plateau in Angola "continued to be imported, bought, and sold under the guise of contract labour" and kept in perpetuity on the plantations. ${ }^{28}$ Nor is the relationship between Fernando Pó and Nigeria akin to the one set up between Fernando Pó and Liberia between 1914 and 1930, when about 10,000 "indigenous peoples were impressed as contract labour" by a small group of senators who did not need to 'deceive' anyone. Instead they deployed the armed forces of the state during recruitment — and assured their returnafter two years of work in "Fernando Po under the guise of contract labor". ${ }^{29}$

Even though panya recruitment was a slaving genre of "kidnapping and smuggling" that continued in colonial Nigeria along the old supply networks, it cannot be thought of as the result of an inertia from the immediately precolonial period, subsisting only where "old elites" preserving an "old older" "survived". ${ }^{30}$ Fernando Pó's recruiters

\footnotetext{
${ }^{27}$ Schuler, 'Kru Emigration to British and French Guiana'; Clarence-Smith, 'Emigration from Western Africa, 1807-1940'; Johnson U. J. Asiegbu, Slavery and the Politics of Liberation 1787-1861: A Study of Liberated African Emigration and British Anti-Slavery Policy (New York: Africana Pub., 1969). For ample French efforts to supply Martinique and Guadeloupe as well as Reunion and Mayotte with engagé labour from Dahomey, Senegal, Gabon and Mozambique see Soumonni, 'The Compatibility of the Slave and Palm Oil Trades in Dahomey', 86; Renault, Libération d'esclaves et nouvelle servitude; Northrup, 'Freedom and Indentured Labor in the French Caribbean, 1848-1900'; Jelmer Vos, "Without the Slave Trade, No Recruitment", 45-64; Stanziani, Bondage: Labor and Rights in Eurasia, 175-196.
}

${ }^{28}$ Miers and Roberts, 'The End of Slavery in Africa', 20, 21, 54; William G. Clarence-Smith, 'Labour Conditions in the Plantations of Sao Tomé and Principe, 1875-1914', Slavery and Abolition 14, 1 (1993): 149-167, 149.

${ }^{29}$ Suzanne Miers, 'Slavery and the Slave Trade as International Issues 1890-1939', Slavery and Abolition 19, 2 (1998): 16-37, 29. See Sundiata, From Slaving to Neoslavery, 123, 143; Sundiata, Brothers and Strangers, 81, 88-98, 249-250.

${ }^{30}$ Lovejoy, Transformations in Slavery, 288, 299; Afigbo, The Abolition of the Slave Trade in Southeastern Nigeria, 100; Patrick Manning, Slavery and African Life: Occidental, Oriental, and African Slave Trades (Cambridge: Cambridge University Press, 1990), 161; see also Paul E. Lovejoy and Jan Hogendorn, eds., Slow Death for Slavery: The Course of Abolition in Northern Nigeria, 18971936 (Cambridge: Cambridge University Press, 1993); Miers, 'Slavery to Freedom in Sub-Saharan 
were initially drawn from groups who had previously had a hand in organizing (and abolishing) the Atlantic and internal slave trade in West Africa such as Aguda or AfroBrazilians and Sierra Leonean Creoles. The majority of recruiters were Efik from Calabar Province, particularly those from Henshaw Town settlements in Oron, and socalled "Cross River Igbo": Abam, Abriba and Aro "resident stranger" merchants with links to Calabar and other smaller waterside trading towns throughout the Eastern Province. ${ }^{31}$ But decades after abolition and with imperial rule quite well cemented in Nigeria, a new generation of recruiters regrouped under the new structural templates provided by Spanish imperial rule and improvised a radical discontinuity in their technique. The Fernando Pó labour traffic was a spike of a defunct repertoire of the earlier Atlantic world, and of the post-abolition Indian and Pacific worlds, an admixture reaching back and forth across continents rather than unfolding along some anachronistic niche or trait perduring into the colonial period.

Tout's sole area of operation was the 'field'-to constantly bring in batches of new recruits. They were heterogeneous, discontinuous and unrelated. Their viability and strategy relied to a high degree on individual histories and capacities to deploy promises within wider structural asymmetries. There were never more than two hundred recruiters at any one time, even during the crescendo in the late 1930s; who their grandparents were or how the census grouped them had only a very loose bearing. Those involved in the recruiting bloom were not a coherent group reproducing an existing status nor did they form a class. They were not headmen,

Africa', 237-64. For the foundational thesis of the resilience of old elites, see Ralph A. Austen, 'The Abolition of the Overseas Slave Trade a Distorted Theme in West African History', Journal of the Historical Society of Nigeria 5, 2 (1970): 257-274.

\footnotetext{
${ }^{31}$ Most Igbo recruiters operated in and out of Bende, but they lived elsewhere, For example Michael Ikeocha, from Oloko, in Bende division, a town whose women instigated the Ogu Umunwanyi or Women's War of 1929, and likely because of that found himself "now living a Calabar" in the compound of Chief Udo Edem. Ikeocha made "his journeys" from Creek Town. British VC (Michie), 28 February 1941, 'Labour Conditions in Spanish Guinea, Appendix C: List of Recruiters and Canoemen', TNA, FO 371/26908. Warren T. Morrill, 'Two Urban Cultures of Calabar, Nigeria', (PhD Thesis, University of Chicago, 1961), 269, notes from his field site, 1950s Calabar, that "all Igbo migrants in Calabar" assured him that the "shrewdest and most successful Ibo traders are those from Abiriba." A reputation carried on into more recent times too, as a blogpost on Nairaland says: "The Abiriba man loves and follows the whiff of money to wherever it takes him, and no matter the risk involved," having "responded to changing economic opportunities" in the colonial period by "developing a strong trade in smuggled gin from Fernando Po." Ebere Ahanihu, "Abiriba And Ohafia: Two Of A Kind', 30 April 2011, http://www.nairaland.com/657067/abiriba-ohafia-two-kind.
} 
"boss-boys" or "gangmasters" who supervised contracted labourers throughout their journey and at the worksite itself. ${ }^{32}$ They were rarely long-term employees; they worked on commission. They were provisionally delegated agents, preparing the tracks who were only loosely affiliated to certain planters or the cacao exporting houses on the island. They were not "friends and relatives", as emphasized in much recent literature on indenture and post-indenture labour migrations. The odd and variable presence of an uncle, friend or community leader, weather as helpful guide and sponsor or as a receiver of commissions, does not get the debate beyond the dichotomy of free and unfree labour very far because it was still others, mostly touts and whoever they distributed shares of their commissions to, who were organizing the logistics of movements; and others still, more often than not state actors, who set the parameters for the conditions of exploitation on arrival. ${ }^{33}$ The frames of ethnicity and kinship in the study of indenture is the gesture of an impasse, a non-confrontation with the paradox of agency, a bypassing of the contradictions and mutuality constituting the relationship between force and choice, placed and constituted by the unravelling of structures, many causes and other forces.

There was no direct continuity with the recruitment techniques of the slave trade, the 'blur' suggested by William Gervase Clarence-Smith is true but it needs to be stretched, inverted and specified: "even more akin to a slave trade was the clandestine

\footnotetext{
${ }^{32}$ Such headmen were integral to Kru (1830s-1890s) labor migrations; see above p. 38. In the "postindenture" Bay of Bengal and South East Asia Elsewhere such recruitment through "boss-boys" was known as the kangani ("overseer" in Tamil) and chu tsai thau ("head of piglets"). Headmen tended to be already previously associated with labourers - and with planters. Ramasamy distils the essence of the kangani, who were often also foreman on the plantations: they were not so much "mediators between capital and labour" but rather "agents of capital", there to "subject labour to rigorous discipline". Palanisamy Ramasamy, "Labour Control and Labour Resistance in the Plantations of Colonial Malaya', Journal of Peasant Studies 19, 3/4 (1992): 87-105, 92.

${ }^{33} \mathrm{McKeown}$, 'Global Migration', 167. For a critique of the "separation between contractor and sardari recruitment", where the latter, the sardar was "perceived to be an 'insider' recruiting within a proximate community and thus less likely to use force and deception in recruitment", see Sen, 'Commercial Recruiting and Informal Intermediation', 5; Prabhu Mohapatra, 'Eurocentrism, Forced Labour, and Global Migration: A Critical Assessment', International Review of Social History 52,1 (2007): 110-15, 113. For a wonderful analysis of the complex social networks in recruitment see especially, Ravi Ahuja, 'Networks of Subordination-Networks of the Subordinated: The Ordered Spaces of South Asian Maritime Labour in an Age of Imperialism (c1890-1947)', in The Limits of British Colonial Control in South Asia: Spaces of Disorder in the Indian Ocean Region, ed. Ashwini Tambe and Harald Fischer-Tine (London: Routledge, 2009), 13-48. For a contemporary critique of "social networks" see Fred Krissman, 'Sin Coyote Ni Patrón: Why the "Migrant Network" Fails to Explain International Migration’, International Migration Review 39, 1 (2005): 4-44.
} 
importation of labour from southeastern Nigeria from about 1900, organized by African canoe owners". ${ }^{34}$ Contemporary humanitarians observed how labourers for the "large European-owned estates" were secured on the "mainland, often by methods reminiscent of old slave days." ${ }^{35}$ Henderson Tapela says that illegal recruitment "began to take the character of the slave raiding of former days. Unwary travellers were kidnapped and canoe-paddled from the ports of Eket, Oron and Calabar". ${ }^{36}$ There seemed to be a "reminiscence", but there was always a slight doubt, a "really" with a question mark: "What really looks like indirect resuscitation of the old slave trade thought to have been completely stamped out, is being persistently and diligently pursued in this district [Calabar] in the form of organized labour recruiting to the Spanish island of Fernando Po by some individuals." ${ }^{37}$ I think the argument can nevertheless be made, that if the fifteenth century island and river based trading network in the Gulf of Guinea witnessed the clear beginning of a commercialized system geared towards importing enslaved Africans onto colonial worksites ${ }^{38}$, it was on Fernando Pó that this system met its unnoticed and confused end in the twentieth century; but not in any linear way, to the contrary it happened through a layering and fission, in bursts and quick reversals.

Between the 1910s and early 1930s most braceros were either recruited by the Liberian state or by the Spanish state and recruiters in Rio Muni, Cameroon and Gabon through separate, usually much more violent, recruiting assemblages. However already by 1935 , the majority of "the braceros who arrive in our colony [were] all coming from Calabar", and indeed from this point on the majority of the islands

\footnotetext{
${ }^{34}$ Clarence-Smith, 'Cocoa Plantations and Coerced Labor in the Gulf of Guinea', 160.

${ }^{35}$ Wieschhoff, Colonial Policies in Africa, 32.

${ }^{36}$ Henderson M. Tapela, 'The Cross River Basin: Colonial Labour Policies and Practices', in A History of the Cross River Region of Nigeria, ed. Monday B. Abasiattai, (Calabar: University of Calabar Press, 1990), 198-214, 210.

37‘The Nigerian Easter Mail Alleges Slavery in Oron', The West African Pilot, Lagos, January 211939.

${ }^{38}$ Joseph C. Miller, Way of Death: Merchant Capitalism and the Angolan Slave Trade, 1740-1830 (Madison: University of Wisconsin Press, 1988), 115-6; Arlindo Manuel Caldeira, 'Learning the Ropes in the Tropics: Slavery and the Plantation System on the Island of São Tomé', African Economic History 39 (2011): 35-71.
} 
inhabitants (including the large immigrant community of traders, smugglers, skilled and self-employed workers and their families) were Nigerian. ${ }^{39}$ "By far the greater number of Cross River people who migrated to seek employment" abroad ended up Spanish Guinea. Yet "an Igbo saying has it that "no one who was comfortable at home ever opted for Fernando Po", 40

Large migration to the towns in Eastern Nigeria were kick started in the late 1920s when the British introduced the poll tax. People moved to "escape tax", "definitely to escape tax" says a district officer of eastern Nigeria in 1930. The sudden tax obligation of 7 shillings was often paid out in bulk to district commissioners by appointed chiefs who were paid for their bureaucratic duties in pounds, so this was easy. For those who suddenly found themselves debtors, interests quickly accumulated to up to $3 £$, and they would be "summoned for this amount and they place[d] themselves in bondage" to creditors and chiefs who "take all our money" says a resident in Aba in 1930. "On account of the tax and various other matters people have pawned themselves." ${ }^{41}$ In the 1930s like generations earlier, many of those entering a labour market were escaping others forms of unfree labour generated under colonial rule. In the districts of Owerri, Aba and Bende where a majority of migrants were from in the $1940 \mathrm{~s}$, the selling and pledging of land became unusually common. In the "hope of gathering the first installment to pay for a bicycle or a [palm oil] press", land pledges were being accepted as a "security for a debt". Land could be seized by creditors for failing to pay back loans and high interests rates, something which had "driven many away from farming to seek their fortunes abroad". ${ }^{2}$

\footnotetext{
${ }^{39}$ GG (Sánchez Guerra) to DGMC, 28 December 1935, AGA, C-81/06867, E-5; British Consul, Yaounde, 4 May 1961, 'Despatch No.46', TNA, CO 554/2502.

${ }^{40}$ Tapela, ‘The Cross River Basin’, 210, 212; Ejituwu, ‘Anglo-Spanish Employment Agency’, 50.

${ }^{41}$ Nigeria and Aba Commission of Inquiry, Notes of Evidence Taken by the Commission of Inquiry Appointed to Inquire into the Disturbance in the Calabar and Owerri Provinces, December, 1929 (Lagos: Government Printer, 1930), para. 18675, 18570; Obadare, 'Nigeria-Equatorial Guinea Relations since 1927', 575-589, 577; Okolie, 'The Transformation of Eastern Nigeria', 461, 463.

${ }^{42}$ A. F. B. Bridges, June 1938, 'Report of Oil Palm Survey, Ibo, Ibibio and Cross River Areas', RHL, Mss. Afr. S. 697 (1), para. 3; see also also Chima Korieh, The Land has Changed: History, Society and Gender in Colonial Eastern Nigeria (Calgary: University of Calgary Press, 2010), 260.
} 
The wages and conditions in Fernando Pó made the island attractive only to the "miserly situated labour" in Nigeria, most migrants arrived "completely destitute and penniless", many "had never worked before" in the imperial sense. They were drawn from the ranks of those who various reasons could not find work in Nigeria, including absent social and kin relations that facilitated money making opportunities and the sums of money needed to pay the initial dashes that would secure placements, training and apprenticeships in Nigeria itself. Some also had their own reason for "a hasty exit from Nigeria, e.g. debts, taxes unpaid, family disputes". ${ }^{43}$ The "evil" reputation of Fernando Pó almost always preceded the spread the "illegal recruiters in the widely scattered areas of recruitment" ${ }^{44}$ Fernando Pó and its recruiters quickly "gained a very unsavoury reputation" after "cases of kidnapping were brought to light" but colonial officials assumed they met with quite "some success", "partly because the very dense population in Onitsha and Owerri Provinces had created a class of landless peasants, who were compelled to turn to wage earning for a livelihood". ${ }^{45}$ But on closer investigation it was clear to those doing the investigative groundwork that only "through such agencies as may exist in Calabar", that is "through the instrumentality of a 'recruiting agent" that anyone found their way into the island's plantation contracts. $^{46}$

\footnotetext{
${ }^{43}$ British LO (Evans) to British Consul General, Douala, 31 August 1945 'August Labour Report No.18', NAE, CALPROF 17/1/278; British VC and LO (Bradley), 4 July 1956, 'Quarterly Report', TNA, CO 554/1346; Chief Secretary Office, Lagos to GG (Manresa), 7 July 1930, AGA, C-81/08146 E-1.

${ }^{44}$ British LO (Lewis), Calabar to Commissioner of Labour, Lagos, 6 December 1943, NAE, CALPROF 5/1/193.

${ }^{45}$ Nigerian Secretariat, Lagos, [undated, 1953], 'Memorandum' RHL, 600.18 s. 21/XI (10).

${ }^{46}$ DO Itu to Resident, Calabar, 11 January 1939, NAE, CALPROF 5/1/194; Commissioner of Police, Calabar to Resident, Calabar, 1 August 1935, NAE, CALPROF 5/1/192.
} 


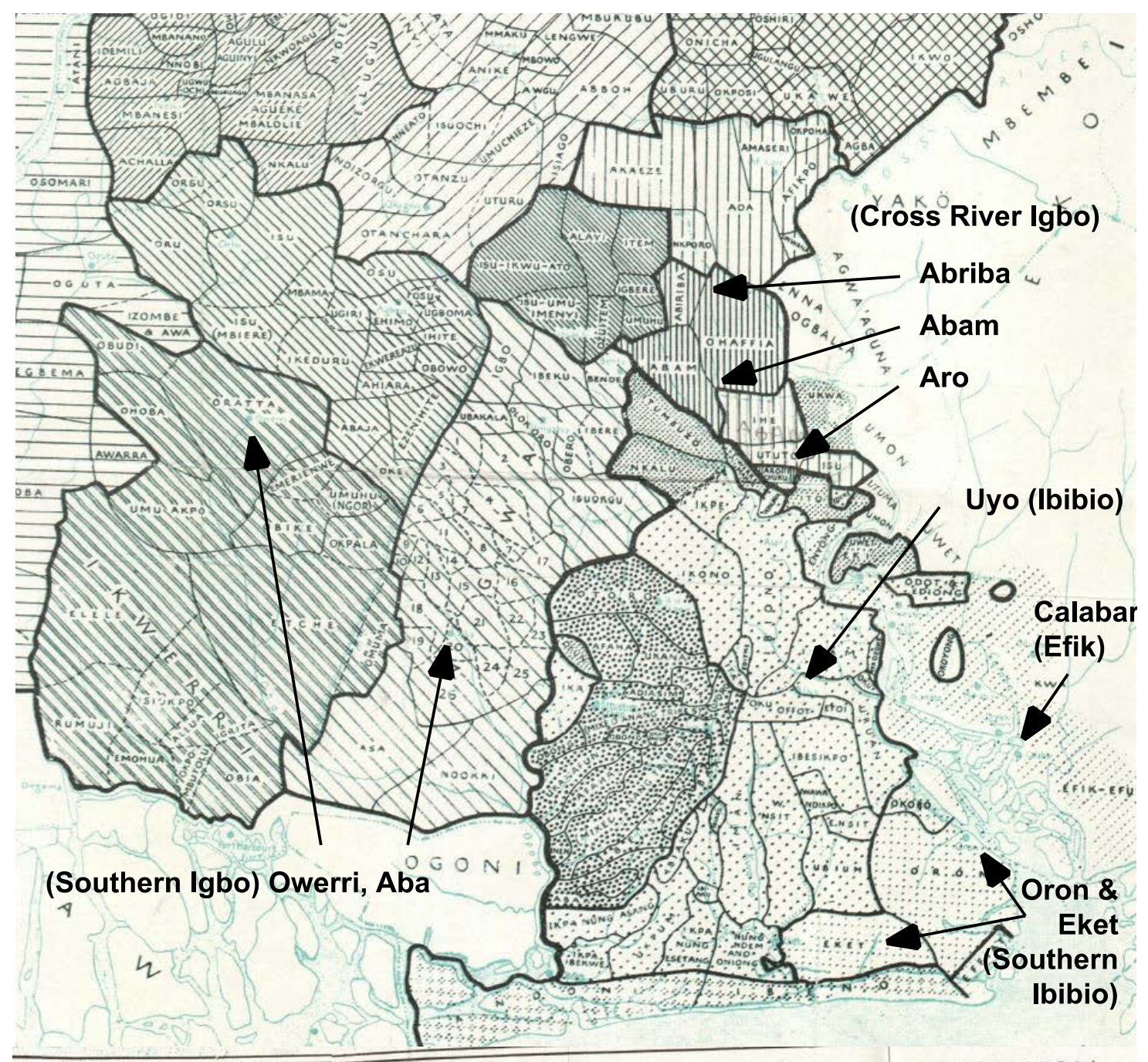

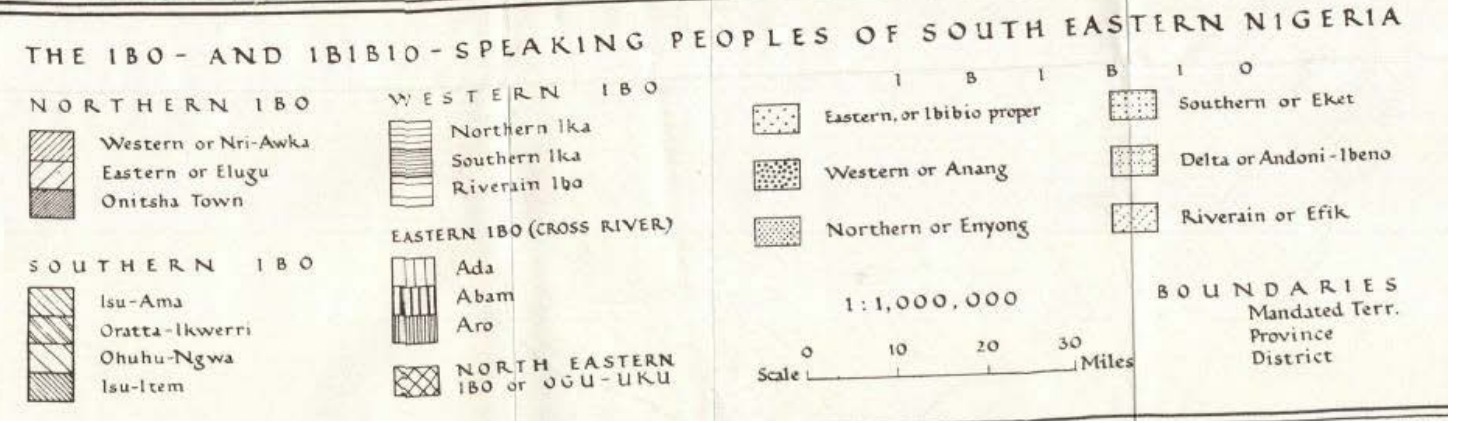

Map 4 Social groupings in south-eastern Nigeria, boundaries approximate ${ }^{47}$

${ }^{47}$ Adapted inset from Forde and Jones, The Ibo and Ibibio-speaking, Appendix. 


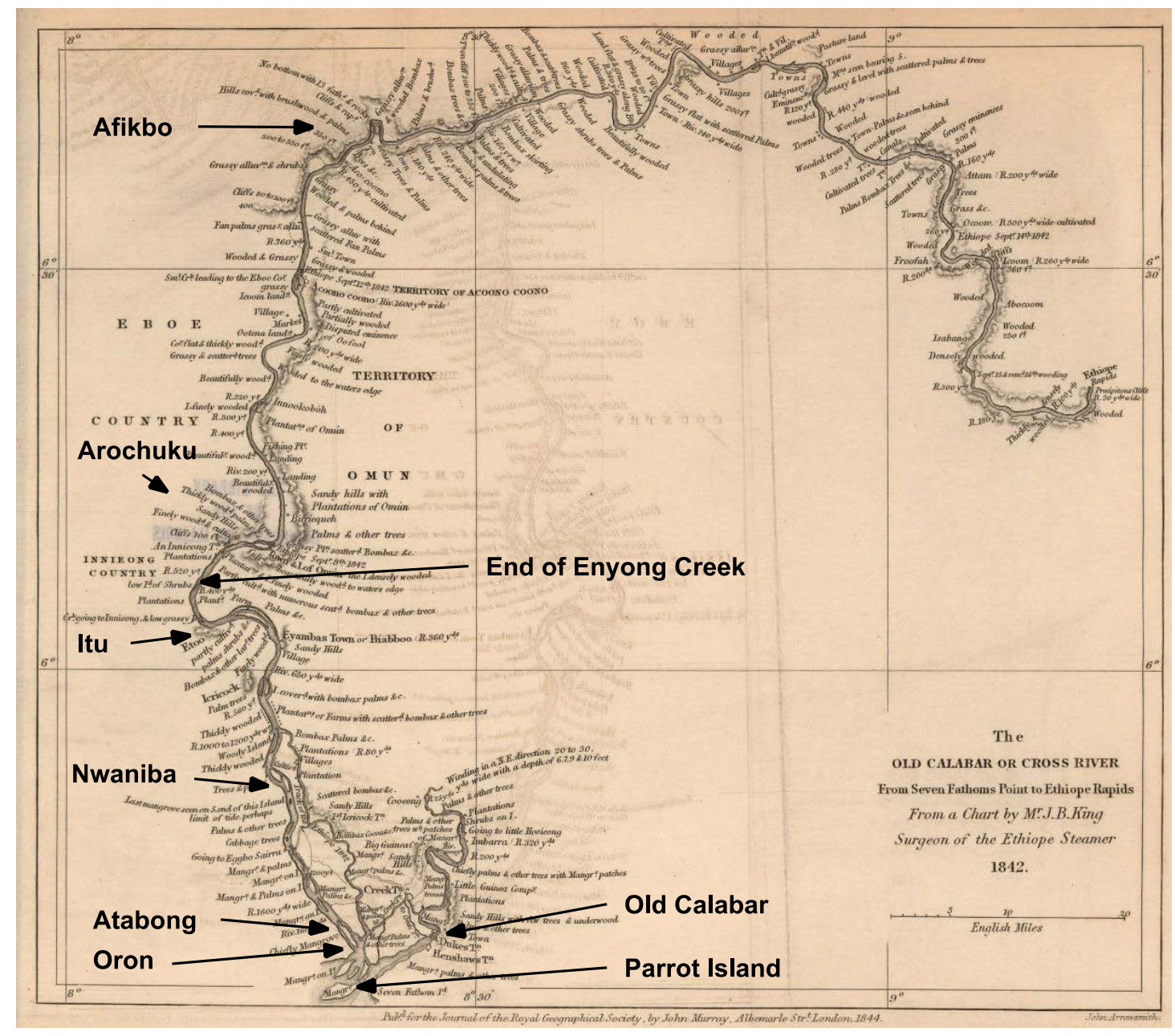

Map 5 Cross River in 1842 with old and new place-names superimposed ${ }^{48}$

\subsection{Economies of Deception}

A clear moment of uprooting violence on land was absent, people wanted to or needed to be on the move, just not necessarily towards the places and under the conditions they ended up in. Recruiters were not armed, they did not purchase or redeem 'existing' slaves or raid for new ones, "as it is as it is unthinkable that nations like France and England, from whose colonies our labour power arrives, would have allowed us to employ procedures that require violence and coercion"- says a Spanish diplomat at a meeting of the ILO in $1935 .{ }^{49}$ A Spanish petty functionary on the island

\footnotetext{
${ }^{48}$ Becroft and King, 'Details of Explorations of the Old Calabar River, in 1841 and 1842', 283.

${ }^{49}$ El Consejero Tecnico a la XIX Conferencia Internacional de Trabajo (Cavestany Anduaga), 22 May 1935, AGA, C-81/12422.
} 
explains that the modus operandi: "deceitful methods operate in la recluta [recruitment] and this is well known by all, well if it wasn't for the manipulation of appearances, the indigenas [natives] would not come to work for us." ${ }^{50}$ Another settler said that while it was "not always necessary to employ cunning and trickery and other despicable procedures, at least half" were set up this way. ${ }^{51}$ It is a good estimate, as various surveys confirm that at least half of Nigerian recruits in this period "claimed ignorance of knowing that they were being taken to work in the Spanish Cocoa plantations". 52

The fact that most braceros did not really want to be there even if they came quite voluntarily following expectations is revealed in one extremely symptomatic incident in 1940. A "rumour had spread" among "the Nigerian indigenas resident on the island" that a British navy ship was waiting at the harbour in Santa Isabel to "repatriate all British subjects on the island". Braceros started "abandoning their place of work en masse"; descending from the "plantations on the hills", they "started to fill the Plaza de España", the central square of the capital by the harbour. They were "gathering on the docks too, and all were carrying their heavy luggage with them." Planters were of course "very alarmed, they thought they would lose all their braceros, as you know, the indigenas of Nigeria make up over ninety percent of all the braceros of this island." 53 The Guardia Colonial returned everyone to the plantations. "Imagine the damage to our agriculture and our colony, if the only source of labour that is available to us now [Nigerians] would meet with any sudden interruption." $" 54$

\footnotetext{
${ }^{50}$ Babiloni Navarro, 'Los territorios españoles', AGA, C-81/12427.

${ }^{51}$ Guillermo Cabanellas, La selva siempre triunfa: novela del África española (Buenos Aires: Editorial Ayacucho, 1944), 35.

${ }^{52}$ Ejituwu, 'Anglo-Spanish Employment Agency', 47.

${ }^{53}$ Secretario General, Santa Isabel to GG (Fontán), 9 July 1940, AGA, C-81/08806, E-'Información con caracter reservado sobre incidente occurrido en Santa Isabel con un Buque de Guerra Ingles'.

${ }^{54}$ Cámara (Carbonell) to GG (Bonelli), 17 June 1947, AGA, C-81/08179, E-5.
} 
Farley Smith, a special investigator sent to the island in the summer of 1939 rounded down his own estimate of $50 \%$ of those "taken" to Fernando Pó who were not "willing to go there", to "possibly 15\%". These "15\%", he says were apparently "for the most part, credulous youths lured there under false pretenses." ${ }^{, 55}$ Farley Smith had rounded down this figure because he like other colonial officials fancied themselves to be amateur barristers, cross-examiners, able to "detect carefully prepared lies"56 and discern "carefully crafted stories" 57 from sight and sound alone-imputing a calculating shrewdness to the recruits that was simultaneously denied to them. Playing judge and mercilessly excluding supplicants, whom he did not see as unwitting dupes, but as cunning and manipulative, Farley Smith says he "arrived at this figure", $15 \%$, after "listening to complaints and making inquiries on the Island" and excluding those "for whom it is natural that having gone willingly and finding they do not like the conditions make as good a story as possible in their efforts to return to Nigeria before completing their contracts." 58 "On arriving at the farms they find the work hard and the hours long" and "no doubt", says a British Consul, "their contract and forced stay of two years appear to be insufferable, hence their pitiable appeals for assistance." ${ }^{, 59}$ An undercover Nigerian policeman reports that "they are all now in the Spanish Plantations serving their term regretfully [...] really suffering a lot and many of them had died - death occasioned by brutal and hard treatment unaccustomed to from the time of their Birth." 60

${ }^{55}$ Farley Smith, 21 September 1939, 'Report', TNA, FO 371/23171. "The usual procedure is to bring the recruits at night down to some small village on the coast or creeks of Calabar province and tell them that in order to get to their destination they have to cross a wide river. [...] The recruits then embark in the canoes and next morning they are well out at sea and it is too late for them to be able to take any action to get away from the recruiter."

${ }^{56}$ Britich VC (Smallbones) to FO (Grey), 13 October 1913, TNA, FO 367/353.

${ }^{57}$ British LO (Evans) to British Consul General, Douala, 31 January 1945, TNA, FO 371/49598.

${ }^{58}$ Governor's Deputy, Lagos to Sec. of State for the Colonies (MacDonald), London, 23 August 1939, TNA, FO 371/23171.

${ }^{59}$ British VC (May) to Resident, Calabar, 13 September 1934, TNA, FO 458/126; also in NAE, CALPROF 5/1/192.

${ }^{60}$ S. Muyiwa to Commissioner of Police, Calabar, 24 May 1936, NAE, CALPROF 5/1/194. 
David Northrup (an early historian of the Igbo and the pre-colonial economies of the Cross River) in his book Indentured Labour in the Age of Imperialism, surveyed the case of Chinese coolies in Cuba, and expressed his incredulity at the fact that $80 \%$ if not $90 \%$ - anyhow, he says, an "improbably high" number —of the tens of thousands of Chinese coolie labourers in Cuba interviewed by a Qing Dynasty Commission of inquiry in 1874, reported that they had been "kidnapped or decoyed" by the "barbarians" in Macao who had sent out "vicious Chinese" as recruiters. ${ }^{61}$ Coolie petitioners explained carefully and clearly how in "recent decades, China is doing business with foreigners", who were "colluding [with] Chinese gangsters whose job is to abduct people. This practice originated in [the British treaty port of] Xiamen and prospers in Macao." From small time beginnings in the 1850s these "vicious Chinese" had "cast their nets in every harbor and their schemes block every road. No matter the wise or the fool, we are all trapped." "Some people used up thousands of gold pieces and were ashamed to go back to their hometowns. Some people were very poor and looked for a job alone. They met friends on their way. Some of these friends were heart-less. These wicked people pointed falsely at a gold mountain and promised to show the way. [They] grew a lotus under their tongues but hid a sharp blade in their stomachs. They deceived people into traps in order to make a profit. They lured people to a foreign land and didn't care about family loss and lineage. I didn't realize that I was tricked until the ship sailed to the middle of the river." 62 Nevertheless, Northup interjects: they "gave the answer they though most likely to obtain their release", he says, and approvingly cites the Qing Commission's conclusions that labourers tended to be "bad characters" emigrating "to escape the results of gambling and crime" or otherwise were "stupid fellows"” easily "ensnared by crimps".

\footnotetext{
${ }^{61}$ Northrup, Indentured Labor in the Age of Imperialism, 57; China and Cuba Commission, The Cuba Commission Report: A Hidden History of the Chinese in Cuba: The Original English-Language Text of 1876 (Baltimore: Johns Hopkins University Press, 1993), 36. Under related circumstances: "Kidnapping was no mere sideline for the bandits that plagued South China during the nineteenth and early twentieth centuries, it was their primary modus operandi". James L. Watson, 'Transactions in People: The Chinese Market in Slaves, Servants and Heirs', in Asian and African Systems of Slavery, ed. James L Watson (Berkeley: University of California Press, 1980), 223-51, 233.
}

${ }^{62}$ Yun, The Coolie Speaks, 245, 96. 
Northrup ends by saying that "the line between voluntary and involuntary is further blurred by the fact that the migrants desperation and ignorance made them easy to cheat and deceive." This was the same line that colonial officers took in Macau, who talked of these promoters of "false pretenses" who could find "easy prey" and "trick" people to "willingly accompany the $[\mathrm{m}]$ to Macao". It is not decisive whether some were under the impression that they "would be working in Macao", while others, as Northrup speculates, after hearing "of the good fortune of clansmen or other villagers in California, undoubtedly offered themselves for employment, not knowing the difference between Peru and California." The key to the whole ensemble is what happened on board ships, as a coolie from Xiamen in 1852 says: "They were beguiled on board the barbarian ship as contract laborers by emigration agents and confined in the hold. After the ship sailed, the said barbarians gave each man in the hold a contract of servitude. If he did not accept he was flogged." The 'barbarian's practice' was not about middlemen and their snake-like hisses, but about despotic stamps and structures of confinement that could nullify a series of communicative encounters. ${ }^{63}$

Touts armed themselves with varying degrees of deception, creativity, theatrics, and the most intimate of illicit relations, double-dealing and betrayal. Their peaceful 'linguistic' technique were made up of important omissions and plenty of embellishments, and were used to solicit an initially affirmative response in the other. Unlicensed and unregulated labour recruiting in Nigeria was banned, not because it was restrictive or necessarily unfree but because it was considered 'too free' and disinhibited, beyond the laws of exchange in the lands of the excesses of thefts and gifts. While British district officers were generally pleased to see the "acceleration of the drift", as they called the emergence of a "pool of surplus labour" or the "tendency of young men to drift to centers of semi industrial employment", they worried about the "drain of labour to foreign possessions" because this "drift" was imagined to come

\footnotetext{
${ }^{63}$ Northrup, Indentured Labor in the Age of Imperialism, 57, 56, 58; Robert L. Irick, Ch'ing Policy toward the Coolie Trade, 1847-1878 (Taipei: Chinese Materials Center, 1982) 95, 205, 33; See also Meagher, The Coolie Trade, 126. As late "as 1904, the Attorney-General for Hong-Kong, prosecuting in a kidnapping case, indicated that kidnapping was rife." Pember Reeves, 'Foreword' of Campbell, Chinese Coolie Emigration, xiv.
} 
from both the 'avarice' of recruiters and the 'promiscuous' expectations of "the uneducated young man, in search of easy money." 64

The recruiters used "lies, deceit, and stealth to get labour from Nigeria", says a journalist in the Nigerian Eastern Mail during the outpouring of the reading and writing public in $1939 .{ }^{65}$ Scholars who have seen the sources say that "recruiters resorted to deception to entice young men to leave their homes". Recruiters "were in the habit of making exaggerated promises [and] of hiding the fact that the labourers were going to Fernando Po". The "sweet-tongued recruiter convinced his victims that Fernando Po was a haven of wealth easily extracted from apprenticeships, shopassistantships and domestic stewardships". ${ }^{66}$ The recruit was "stuffed with sufficient falsehoods to induce him to accompany the recruiter to Fernando Poo or sufficiently far on the journey as to make it impossible for him to turn back when he finds out the truth." ${ }^{67}$ Touts could operate with a manipulative indifference and a mild kind of sadism, but they wielded no weapons, they could not even be being too pesky or they would fester, they simply latched on to people who were already on the move, redirecting the desire of migrant labourers and often leading them to thwarted hopes and an unwilling fate on Fernando Pó's plantations. They laid pictures over traps and seemed to be able to do in the quintessential tout's pose, with their own hands casually folded behind their own back.

Dandeson Green, a Krio or Saro and "veteran Calabar reporter" with pro-colonial credentials, writes that while "many Nigerian labourers went to Fernando Po of their own accord", a "very considerable number are taken, either by force or with the

${ }^{64}$ DO Opobo to Resident, Calabar, 10 June 1947, NAE, CALPROF 3/1/1447; Resettlement Office, Uyo to Resident, Calabar, 1 July 1947, NAE CALPROF 3/1/1447.

65‘The Fernando Po Slave Traffic’, The Nigerian Eastern Mail, Calabar, 25 February 1939.

${ }^{66}$ Pratten, The Man-Leopard Murders, 166; Osuntokun, Equatorial Guinea Nigerian Relations, 27; Tapela, 'Nigerian Labour for Fernando Po', 48.

${ }^{67}$ Timothy Farley Smith and Nigeria, Report on employment of Nigerian labour in Fernando Poo (Lagos: Government Printer, 1931), para. 6. 
promise of 'Utopia', by ruthless smugglers and illegal native recruiters." ${ }^{68} \mathrm{~A}$ trader from Lagos says that he came across a group of recruiters who disembarked with a group of unwitting recruits whom they had brought "under the pretext" of being trading assistants who were hired to carry trade goods in and out of the island: "boys whom they have impressed with the notion of FERNANDO PO being an El Dorado for the unemployed and depression in Nigeria and upon their arrival there are made over to some farmers for some inducive amounts of money". ${ }^{69}$ Ruthless peddlers of 'utopia', proponents of 'El Dorado': the "chief trouble is caused by the army of recruiters who entice young people away, their story of Fernando Po being a land 'flowing with milk and honey' is, however, true". ${ }^{70}$

There was indeed a lot of accumulated and concentrated wealth circulating in Fernando Pó. Spanish Guinea accounted for 1\% of total exports from Africa in 1960, ten times its weight or size. ${ }^{71}$ A British missionary in observed in 1938 that Fernando Pó was "so different form anywhere else in West Africa [...] it is an amazingly wealthy little island". ${ }^{72}$ Much of the money to be made went to those who "import foreign men to suck dry its honey". ${ }^{73}$ For the mix of official and underhand pay-outs from the Spanish labour officer and individual planters, the recruiters were "prepared

\footnotetext{
${ }^{68}$ Dandeson Green, 'Recruitment of Labour To Fernando Po is Done Under Treaty With Spanish Govt', Eastern Nigeria Guardian, Port Harcourt, 17 April 1947; Dandeson Green was in 1952 appointed "Labour Delegate to the Agency" of licensed recruitment to "provide propaganda which will encourage recruitment and to combat any adverse criticism by the popular press in the Eastern Region, Nigeria." British VC and LO (Bradley), 'Fernando Poo, Report No.3/1952', 31 September 1952, TNA, FO $371 / 96714$.
}

${ }^{69}$ Olatunji Sapara, n.d. [1934?] contained in Commissioner of Police, Buea, Cameroons, to Resident, Calabar, 31 January 1934, NAE, CALPROF 5/1/192.

${ }^{70}$ Special Correspondent, 'Fernando Po Labour Conditions', The Nigerian Daily Times, Lagos, 13 July 1939.

${ }^{71}$ Pélissier, Los territorios españoles de Africa, 44, 62; DGMC, 1960, 'Repercusiones en la Regional Ecuatorial española, de la situación general en africa', AGA, C-81/11852, E-4. Spanish Guinea only had about $0.1 \%$ of Africa's land and population. Correspondingly GDP per capita was $135 \$$, in contrast to for example Nigeria where it was 12\$. GDP in Fernando Pó in the 1960s was 14737 pesetas, higher than 29 Spanish provinces, that is, almost all of them; Ballano, Aquel, 548.

${ }^{72}$ Dodds, July 1939, 'Notes on Visit to West African District, February to June 1939', SOAS, MMS, MMS/Special Series/Notes and Transcripts/FBN 1 (fiche 15-17).

73 'Writer vehemently condemns idea of Labour Recruiting to Fascist Territory', Eastern Nigeria Guardian, Port Harcourt, 1 March 1945. 
to shangai, trick or, by any method open to them to persuade their country men to come over here, provided that they themselves make a handsome profit out of the deal." "74 The "recruiters at certain seasons asks and gets as much as $£ 15$ per head [with] no questions asked", a sum higher that the wages for two years contract and about the same as the annual average income in the Eastern Provinces. ${ }^{75}$ Indeed it was the "lucrative commissions" which Fernando Pó's recruiters could command that gave their activities, in the eyes of scandalized colonial contemporaries, "the character of a slave trade." These commissions were seen by British colonial officials across the empire as "“a reward for extra cunning in inducing coolies [or even as a] compensation for the risk run in unlawfully inducing or compelling them to go." It “was risk-money, an incentive to 'iniquity' or outright crime."76 On Fernando Pó, for new recruits "planters would not only pay for their transport costs, but for taxes, passports, the wage-advances that aren't usually deduced from the wages, etc. This etcetera, is actually the lions share, and includes expenses which it would be prudent of us not to declare"- the "lions share" was always the recruiters commission. ${ }^{77}$ The total cut that these brokers received was always formally illegalized. It was set by the recruiters themselves and out of regulatory reach.

Touts offered a "free ride", no one paid for their canoe passage to Fernando Pó, there were no tickets, only arrangements and their errant potentials. This made the barrier to emigration non-existent, but recruits wound up paying for their own displacement. This was more clearly the case in the early 1930s when Nigerian recruiters first came on steamers. A ticket to Santa Isabel, even from nearby Nigeria, was expensive, almost half a pound, several months' wages of a bracero. The recruiters paid for

\footnotetext{
${ }^{74}$ British VC and LO (Bradley) to Commissioner of Labour, Lagos, 14 April 1953, 'Annual Report', TNA, FO 371/102612.

${ }^{75}$ Minister of Economic Warfare, Special Operations Executive (Simpson), to Commissioner of Labour, Lagos, 20 December 1942, 'Final Report', TNA, HS 3/77; British LO (Nery), 17 June 1943, 'Nigerian Labour in Fernando Poo', TNA, CO 554/127/15.

${ }^{76}$ Carles, Misioneros, negreros y esclavos, 34; Sen, 'Commercial Recruiting and Informal Intermediation', 15, citing Deputy Commissioner of Ranchi (Streatfeild) to Commissioner of the Chota Nagpur Division, Ranchi, 13 April 1899, 'Letter No 457', West Bengal State Archives, Kolkata, Emigration Department, Financial Branch, April 1899, A62-128.
}

${ }^{77} \mathrm{GG}$ (Manresa) to DGMC (Canovas), 16 May 1931, AGA, C-81/08095, L-2, E-20. 
tickets, bribes, the necessary counterfeit paperwork, and other travel expenses, but those recruited were "made to sign an I.O.U. acknowledging that should they fail to take up contract on the island they would owe three pounds to the recruiter". ${ }^{78}$ By the mid 1930s hundreds of new Nigerian recruits were arriving every month on the steamers, "their passages" had been paid "by a recruiter against an IOU", but only "if they do not contract to work in Fernando Po will the IOU be enforced." Meaning that once a "labourer is here he is more or less forced to contract although he may not like the conditions on closer acquaintance." 79 This type of debt ticket system did not operate on the canoes, though the promise of an advance often did. Being underpaid during the first contract meant that new recruits were essentially paying for their own transport, retroactively while working off the first contract.

The substantial wage advances that was sometimes promised to them went straight into the hands of the recruiters who dropped them off at the Curaduría in Santa Isabel. Almost no one ever saw this advance money or dash the first time around, instead they were met with irrevocable contract lasting a minimum of two years, with formal wages equivalent of the sale-price of 3 large yams a month. The "recruits are taken before the Curador Colonial or one of his staff and told that they are going to contract to Señor [Mr. so and so] for two years at five dollars a month; before this statement has sunk in they are outside the office and their contract books are being filled in. They have been contracted and it is too late for them to 'change their minds' as some of those who have persisted stating that they did not wish to contract are accused of doing." ${ }^{80}$ British labour officers in Fernando Pó and elsewhere worried endlessly on the precise explicative moments of this contract signing, because more often than not "the contracts were so ill-explained that the effect upon the illiterate" hired worked "was the same as if they had been deliberately cheated." ${ }^{81}$ The Vice

\footnotetext{
${ }^{78}$ British Consul-General (Yapp), Monrovia, 17 September 1936, 'Report On Employment of British Coloured Labour in Fernando Po, as the Result of a Visit made August 29th-September 1st, 1936' TNA, CO 554/105/3.

${ }^{79}$ British VC (May) to Chief Secretary to the Government, Lagos, 6 July 1936, TNA, FO 458/126.

${ }^{80}$ Farley Smith, 21 September 1939, 'Report', TNA, FO 371/23171.

${ }^{81}$ Guy C. Mhone, The Political Economy of a Dual Labor Market in Africa: The Copper Industry and Dependency in Zambia, 1929-1969 (Fairleigh: Dickinson University Press, 1982), 78. In the coolie
} 
Consul said that "boys are ignorant of the condition of plantation labour here, and agree to everything that is put to them in accordance with the suggestions of the recruiters." 82 "The recruiters assist in this procedure as much as they can (and they can do a great deal) in order that there shall be no argument over the fee that they have already agreed to accept from the prospective employer.” It goes without saying that recruiters would invariably "fail to mention that employment conditions were unlike Nigeria in that the workers would be bound for two years, with very little chance of changing employer and no chance to visit home." 83

On arrival "the police department takes charge of them and see that they all get employment". Arrangements for commissions were made by "unlawful recruiters mostly" and some "old hands who return with boys to his Master". These mediators "name the Farms or masters with whom they will work. These claimants sign for them and the [braceros] are taken to the Curaduria" to receive a copy of their contract. According to J.W. Kicks-Dadzie, an investigative journalist from the Nigerian Daily Times it was this commission "which most of the labourers resent when they happen to hear of it." 84 For "new arrivals", the extent and amount of dashes and commissions handed over to recruiters was often "completed over their heads", they were "not aware that the tout had made capital out of the recruitment and that the employer has had to pay far more than may appear". ${ }^{85}$ Canoe passengers "found themselves to their dismay, being disembarked at Santa Isabel (Malabo) and

trade too, while the recruiter of course would say that each one of the Chinese emigrants had signed an agreement written in Chinese and Spanish that they were indentured for a period of eight years in Cuba, the "truth of these statements is doubtful because it was unlikely that any of the emigrants could read and write, which meant they were at the mercy of whatever the coolie agents had told them." Robert J. Plowman, "The Voyage of the "Coolie" Ship Kate Hooper October 3, 1857 - March 26, 1858', Prologue Magazine 33, 2 (2001).

${ }^{82}$ British VC (May) to Resident, Calabar, 13 September 1934, TNA, FO 458/126; also NAE, CALPROF 5/1/192.

${ }^{83}$ Farley Smith, 21 September 1939, 'Report', TNA, FO 371/23171.

${ }^{84}$ Kicks-Dadzie to Resident, Calabar, September 1939, 'Confidential Report: Labour in Fernando Poo', NAE, CALPROF 5/1/195; see also Tapela, 'Nigerian Labour for Fernando Po', 48; citing his interview with the Nigerian Federal Minister of Labour, Calabar, 31 August 1978.

${ }^{85}$ British VC (Lewis) to Commissioner of Labour, Lagos, 11 June 1946, 'Illegal Recruitment in Nigeria by “ganchos” appointed by Spanish Employers', NAE, CALPROF 17/1/278. 
auctioned to waiting plantation owners." 86 The often delayed realization of the exchange of the commission is why a single blow did not need to be thrown by any middleman to consider oneself temporarily enslaved; workers were bound on site and considered themselves to be effectively working almost for free. Touts did probably often offer workers the vision of a long-term choice, sometimes the only choice they had, and workers might have followed suit as an expression of agency, with the expectation that savings of pounds in double digits could be made, enough to cover the cost of setting up an independent business, buy land or cover bridewealth, but only after a further contract.

\subsection{Voices from the Archives}

The recruiters appropriated subjectivity and labour through receiving their commission, a process experienced as kind of avarice of accumulation at the expense of others. As Ekpe Eyo, a Christian convert from Uyo, who managed to get a letter through to his father through the Methodists mission in Fernando Pó, says about his recruiter: "greet Etim Asibong warmly for me for he brought me here to stay here, and went back in peace and earner his money and ate things and live and let me die and suffer." ${ }^{87}$ An anonymous letter from a labourer contracted in Fernando Pó does not explain how he has was recruited, and irrespective of whether he was deceived as to the destination, he says that "an eket man has brought me here to sell for $7 £$, if god keeps me alive until it reaches the years for which he sold me, i shall come home", ${ }^{8}$ An Ibibio petitioner on the island representing a group of imprisoned workers denounced the "traders bringing the people to this country in awfully way" because they were "saying that we were going to Tico or Victoria", on an offer to work in the large British and German plantations in British Cameroons, many of which were "accessibly only by water". There, the labourers were increasingly from Nigeria who

\footnotetext{
${ }^{86}$ Tapela, 'Nigerian Labour for Fernando Po', 48.

${ }^{87}$ Ekpe Eyo, Santa Isabel to Eyo Ubon, Afaha Atai, Uyo Division, Calabar Province, 2 September 1938, NAE, CALPROF 5/1/194 [original in Ibibio in NAE, CALPROF 5/1/195].

${ }^{88}$ Letter to Etim, [n.d., received by the Resident at Calabar from the Hope Weddell Institute in July 1934], NAE, CALPROF 5/1/192.
} 
were "for the most part recruited by Efik contractors belonging to Calabar" and were brought "by canoe from Oron." 89

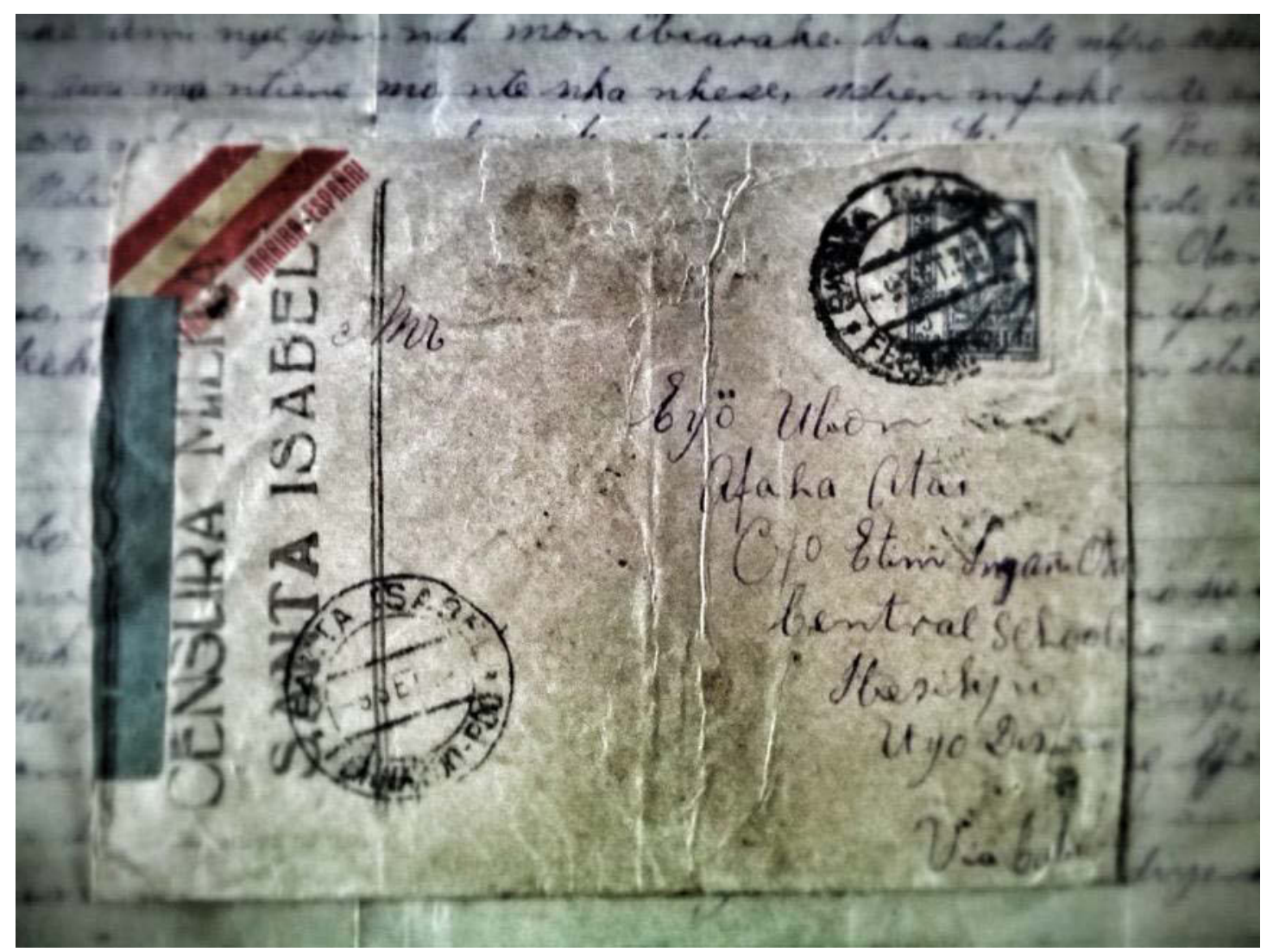

Figure 5 Ekpe Eyo's letter, 2 September 1938

For the petitioner the art of deception was of secondary correlate order, the realization of what panya meant, took place only when contracting took place and commissions had been exchanged. The petition ends with a startling thesis: "I am telling you fact and clearly that [the] canoe-men [are] total selling person to those people [planters] by a great lot of money. Thats why slave is better than us in thousand upon thousand way." 90 The recruiters carved out for themselves an extraordinary slice of profits gained through the labour market they were themselves generating. The recruiters' commission was well beyond the costs surrounding their labour of logistics which covered the ensemble of brokers, paddlers, bribes, and the arrangers upstream and

\footnotetext{
${ }^{89}$ Orde-Browne, Labour Conditions in West Africa, 74; Nigeria, 'Report on the Administration of the Cameroons under British Cameroons for the year 1938', TNA, CO 583/239/5.

${ }^{90}$ Petition signed 'Your Prodigal Sons' to Resident, Calabar, 24 March 1936, NAE, CALPROF 5/1/194.
} 
downstream, including chiefs and false friends and sub-touts on the island itself. Because of this, "judged solely on the question of motive" - the "thought of nothing else but the prospect of earning the promised commission on the transaction"recruiters were considered by one newspaper columnist after another "to stand on practically the same footing as the local slave dealers of the early days". 91

Tapela makes the distinction between outright abduction and misinformation. The former forms part of the topos of the slave trade and is usually referred to as such in the sources. Such instances seemed to be subdivide into two: the kidnappings of children on the one hand, and the other of literate and educated adults, often professionals. There "was evidence that children were being stolen and sold to the island of Fernando Po in a manner similar to the kidnappings of the precolonial period", and some of the evidence suggest that such children accompanied some of the better placed migrant labourers, to work in their households. ${ }^{92}$ On the other hand, it was quite common that the victims who were "shanghaied from Calabar", and "taken to Fernando Po against their will and arrangement" were actually ordinary passengers and "teachers, traders etc. going on buisness boarding canoes" which daily would left "Oron or Calabar by night". ${ }^{93}$ Rumours of kidnapping saturated anonymous transportation hubs, but people still needed to be on the move, obligatory transit points became infused with insecurity, alarm, caution and suspicion. If they could avoid it people did not travel alone or night. ${ }^{94}$

\footnotetext{
${ }^{91}$ Observer, 'Matters of Moment', The Nigerian Daily Times, Lagos, 15 July 1939; 'Spanish Slavery', The Nigerian Eastern Mail, Calabar, 11 March 1939.

${ }^{92}$ Saheed Aderinto and Paul Osifodunrin, "“500 Children Missing in Lagos": Child Kidnapping and Public Anxiety in Colonial Nigeria', in Children and Childhood in Colonial Nigerian Histories, in ed. Saheed Aderinto (New York: Palgrave Macmillan, 2015), 97-121, 102; Secretary's Office, Eastern Provinces, Enugu, to Commisioner of Labour, Lagos, 14 July 1949, NAE, CALPROF 7/1/458; 'I was sold as a slave at the age of two', Daily Times, Lagos, 11 June 1958.

${ }^{93}$ British LO (Nery), 17 June 1943, 'Nigerian Labour in Fernando Poo', TNA, CO 554/127/15; O. Archibong to Resident, Calabar, 23 January 1939, NAE, CALPROF 5/1/194.

${ }^{94}$ Misty L. Bastian, 'Fires, Tricksters and Poisoned Medicines: Popular Cultures of Rumor in Onitsha, Nigeria and Its Markets', Etnofoor 11, 2 (1998): 111-32, 123; Julien Bonhomme, 'The Dangers of Anonymity: Witchcraft, Rumor, and Modernity in Africa', HAU: Journal of Ethnographic Theory 2, 2 (2012), 205-33, 226.
} 
Victims were accused of being heedless and unmindful, but succumbing to subterfuge is a very nuanced process. Even in areas far from Oron where people felt less vulnerable, people could be kidnapped on the open water, such as Peter Udo who reported, that as he was "on his way home from a Cameroons plantation" he was told by the canoe-man "to change canoes" only to be "transported to Fernando Po" with five others. ${ }^{95}$ The same canoes carried both the misled and the outright kidnapped, for example in July 1944 on the same canoe was one "schoolboy from Calabar" who boarded it having been promised a job as a trading assistant on the island, "deceived by the canoman whom he knew". Also on it was "a soldier who had been up country to visit his relations" making the "trip from Oron to Calabar." Both woke up the "next morning on the Island, and [were] sold and contracted." Important and key British officials managed to turn the way to panya into the failing of "simple minded natives" who "have been induced to join the canoes in the expectation of being given a lift downstream, only to find themselves landed in Santa Isabel.",96

District Officers throughout the Eastern Provinces pithily summarized the spate of inquiries submitted by "relatives worrying over the whereabouts" of their family members who had been "taken away by strangers to work at Calabar". But not having "been traced" their "relatives fear that they have been shipped to Fernando Po." Recruiters were shifting further north and west, and everywhere they had been seen "prevailing on youths by specious promises and glowing accounts of conditions obtaining in the plantations near Calabar and in the Cameroons, to accompany them" only to end up being "taken to Santa Isabel". ${ }^{97}$ But it was not that simple; colonial authorities fixated on the narrative that the broker could get away with tricks because of the "gullible" and "ignorant peasants from the Ibo and Ibibio areas" who were being brought over to Fernando by 'unscrupulous native 'black-birders' who earned a

${ }^{95}$ DO Eket to Resident, Calabar, 16 January 1939, NAE, CALPROF 5/1/194.

${ }^{96}$ British VC (Lewis) to British Consul General, Monrovia, 12 July 1944, 'Nigerian Labour in Fernando Po, Report No. 5', TNA, FO 371/39661; British VC (Twigge-Molecey) to British Consul General, Monrovia, 18 February 1939, TNA, CO 554/119/5.

${ }^{97}$ DO Uyo to Resident, Calabar, 11 January 1939, NAE, CALPROF 5/1/194; DO, DO Abak to Resident, Calabar, 10 May 1939, NAE, CALPROF 5/1/195; DO Opobo to Native Court Clerks, Ibibio and Annang, January 1939, NAE, CALPROF 5/1/194. 
lucrative livelihood by kidnapping" them". ${ }^{98}$ It is as if they were displacing blame onto the absence of an internalized corporate-liberal concepts of 'due diligence' prior to a transaction, a being that is not yet twisted within a political economy-paranoiac, pre-emptive, never at ease, shrewd from the outset, gliding across space only through sovereign movements.

The fine-grained archival material-hundreds of depositions, letters home, voices from police and press reports - reveal that each recruitment case or scenario had its own iteration of creative opacity and varying degrees of misinformation rendering 'informed' consent technically null and void. Experiences varied, for example: Affiat and a group of his friends were recruited by "one lady in Henshaw-Square at Calabar named Ne Edak" who was "making a great craftiness before she" brought them to a plantation belonging to a Spanish lawyer, Estrada, "the worst farm in the Fernando Poo"; 99 someone, Denis Ama from Owerri, in contrast was completely unfazed by recruiters and did not raise issue regarding working conditions. He says he went "to Calabar to search for work" and had worked as "a labourer" at a British colonial "palm factory", an Efik owned plantation at Adiabo and then at Fernando Pó, where workers' "duty is general clearance and cocoa seed plantation - we dig holes and lots of grass clearing"100; someone, Ekpenyong Etim a trader from Calabar who on the island saw "boys came out in quantum" and "was sad when seeing them, because [they] come and die", brought by "those tradders [who] make tradding of boys, [not] only the tradding of goods" and "signed the boys with bad amount of 10/- [wage] in bad farm they died away hopeless, Nigeria's boys simple die like fowls"; ${ }^{101}$ someone, Akpan Okono, who accompanied his brother who was going anyway to Fernando Pó

\footnotetext{
${ }^{98}$ Nigeria, Annual Report on the Department of Labour, Nigeria, for the Year 1943 (Lagos: Government Printers, 1945), 11.

${ }^{99}$ Petition signed 'Your Prodigal Sons' to Resident, Calabar, 24 March 1936, NAE, CALPROF 5/1/194.

${ }^{100}$ Denis Ama, Calabar, 10 October 1933, 'Deposition', NAE, CALPROF 5/1/192.

${ }^{101}$ Ekpenyong Etim to [n.n, probably Resident, Calabar], 2 June 1936, NAE, CALPROF, 5/1/194. Fowls were the most common sacrificial object in south-eastern Nigeria, where peasants would need to sacrifice them for various ends. One of Simon Ottenberg's informants in mid twentieth century Igboland, while sacrificing a hen called upon a deity to keep "Ibe's brother, who was working at Fernando Po [to] remain well." Simon Ottenberg, Igbo Religion, Social Life, and Other Essays, ed. Toyin Falola (Trenton: Africa World Press, 2006), 113.
} 
because he had heard "there was much money and that it would be easy to save up"; someone; Okpay Awa from a village in Bende who "followed his friend Kalu Ukay who told him he was going to work in Victoria" but Kalu "brought him to Oron and handed him over to the canoe-man Sambo Ekpa"; 102 someone, one Bronwson Edem Ekong of Eket, who had started to trade but "lost his money and became stranded" on the island and contracted himself to a plantation where "tobacco, snuff and free medical treatment" was provided, and who subsequently embarked on a short career as a recruiter until he was arrested in $1938 ;{ }^{103}$ someone, Anele Nwosu of Owerri and Elijah Chiolu of Ohoada, who were "at Nwaniba, Uyo, as part-time labourers to U.A.C. [United Africa Company] and at other time as petty traders" when "One Abriba man advised us to accompany him to Victoria as traders. The two of us conjointly bought 100 yams (£5), two bags crayfish (£1.16/-) and two tins of palm oil (18/-). We all embarked on a canoe at Nwaniba. To our surprise the Abriba man (Eni) clandestinely brought us to Fernando Poo and contracted us to work for Aselope at Bispa"; ${ }^{104}$ someone, Wilson Bassey, a "probationary Teacher" who in 1944 "resigned due to my aim of joining the army", but on his way to Calabar the "junior clerk in John Holt Office called Utche deceived me not to join the army" by promising him a clerical job "in the shop" of a merchant in Fernando Pó. In a moment of indecision that he came to regret and remembering his anxiety during his job search, he confides to the British Consul whom he petitioned: "as you know an applicants heart is always in a circulation and not steady". Wilson had been in panya, he realized that once under contract there was no going back, "a matter of no help as I am under contract, I

\footnotetext{
${ }^{102}$ Inpector de Trabajo (Blesa Boloix), Santa Isabel, 20 June 1948, 'Informe: Finca de Don Antonio Fernandez y Cia', AGA, C-81/08214, E-1.

${ }^{103}$ DO Calabar to Resident, Calabar, 3 December 1932, NAE, CALPROF 5/1/192; The six prosecuted were, George Oke, Stephen Onwutibe, Bassey Umo, Brownson Edem, Bassey Okon and Peter Esien, "Two of whom are Ibos, three Efiks and one Ibibio." Supt. of Police, Calabar to Commissioner of Police, Lagos, 30 December 1938, NAE, CALPROF 5/1/194; British LO (Lewis), Calabar to Commissioner of Labour, Lagos, 6 December 1943, NAE, CALPROF 5/1/193..

${ }^{104}$ Statement of Anele Nwosu of Ameke Owerri and Elijah Chiolu of Umuochita Diobu, Ohoada Division, in British VC (Lewis) to DO Uyo, 17 February 1949, NAE, CALPROF 7/1/464.
} 
am serving as a labourer in the plantation of Finca el Pino. It is a great pity to me as I am such a great suffering". ${ }^{105}$

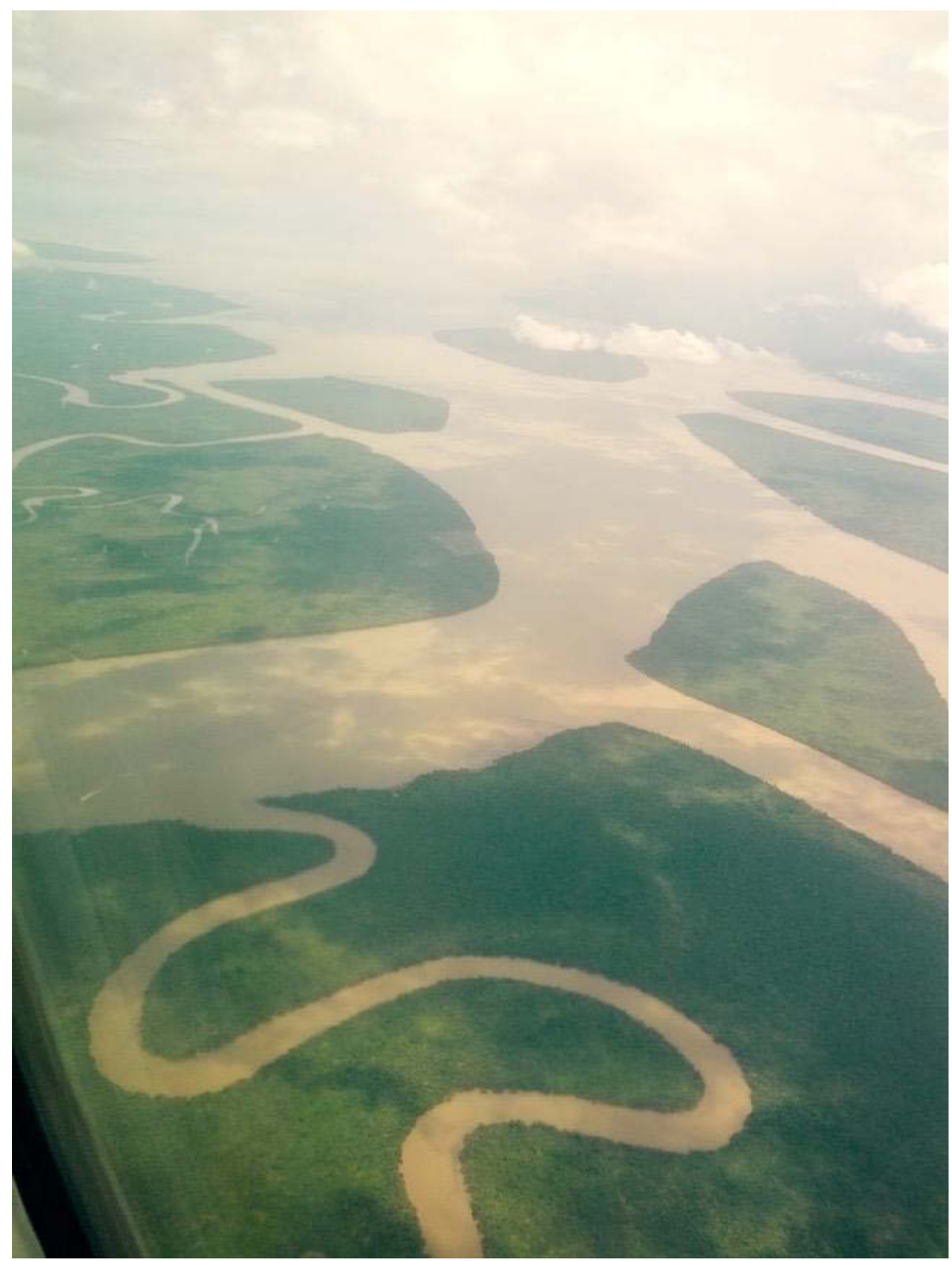

Figure 6 Aerial view looking south from Calabar; Oron top right, July 2012 ${ }^{106}$

For recruitment to oscillate this way an entire field was required, not only a technique, not only the "exceptional and peculiar gifts of the able recruiter". ${ }^{107}$ The head-hunter

${ }^{105}$ Wilson Bassey to British LO, Santa Isabel, 9 June 1946, NAE, CALPROF 17/1/279.

${ }^{106}$ Bioko is 127 kilometres in the direction straight up through the middle of the picture. Oron it visible on the top right. Parrot island is the one in the middle under the clouds. Calabar 'south' is just underneath and the urban center and sprawl goes northwards.

${ }^{107}$ Orde-Browne, The African Labourer, 52. 
or human resources specialist in order to get deliver results and get their commissions, more often than not, transformed themselves into what were known in Nigeria as "confidence men" or wayoman. ${ }^{108}$ The irregularity and opacity of these recruiters should not be taken as "explanations for the inequities and exploitation surrounding migration", rather their techniques and infrastructure and resulting suffering are put into play and funded by structural links to the imperial laws that enabled the demand and the conditions of exploitation. ${ }^{109}$

\subsection{Touts and the State, Nigeria}

Before I go on to argue how the contract itself generated the intensity of recruitment, I will show one more quite typical case of panya recruitment, in fine detail. Late in 1938, the DO of Eket went on tour of his division and at Okopedi, the last town on the road to Oron from Aba, his translator, out on a late evening stroll, "Mr. J.I. Peter, met a party of 19 Ibo men" marching "on foot to Oron". This party was quiet, they "had removed [their] boots for the night march," but "he overheard [them] grumbling to each other that they could not see why they should be made to travel at night". They had "started out from Aba in a lorry" that morning and at Okopedi they stopped to meet the paddling crew, to plan a rendezvous in "one of the little creeks near Okopedi where canoes will be waiting." Startled and after some commotion, the party was led to the nearby rest house where the DO was staying the night. The DO tried to arrest the only non-Igbo among them, while remembering being quietly impressed with “George Matthew Offiong, alias Asuquo Bassey" whom he described as a "literate, rather smooth-tongued person." Under interrogation "Offiong insisted that he had been sent by 'Mr.H.G. Brown Manager of the Adiabo Plantation'”, a U.A.C. rubber plantation east of the Cross River near Calabar, "to recruit labour, but he had no document to prove this." Offiong had "represented to the men" the same story, and by "his own statement" recounts how he had "secured introductions" to "a chief (whose

\footnotetext{
${ }^{108}$ Akinlolu Ake, 'In Nigeria Parents warn your Children', [newspaper?] 11 September 1954, in RHL, MSS. Brit. Emp. S.24 J.50.

${ }^{109}$ Adam McKeown, 'How the Box Became Black: Brokers and the Creation of the Free Migrant', Pacific Affairs 85, 1 (2012): 21-45, 21.
} 
name, the men say, is Abang Chibwu) and by means of those persons recruited 19 men." Before they left Aba, "the men demanded that the conditions of service be given to them in writing"; insisting that they "would not have gone unless they had the conditions in writing."

Offiong did produce a document, it was indispensable and incriminating, its strength and weakness was that it could be deployed with brazen confidence and meticulously inspected. It was a sheet of paper with the header-typo and all- "'Robber (sic) Plantation Adiabo."” This was a felicitous spelling mistake, both because it is what caught the DO's eye and confirmed his suspicion, and because Offiong, while not a 'robber' was a con-artist, almost fully literate, and able to produce or source forged documents. While the DO was "convinced, he was trying to carry [them] away to Fernando Po" he "had no charge against Offiong". There had been no "offence in the nature of deprivation of liberty" as there was "nothing in the Criminal Code to prevent a person inducing another to accompany him under false verbal promises." The DO called it a night and "advised the men" to "keep an eye on" Offiong, and this "they did, and when Offiong tried to go away during the night, they stopped him." The "next morning" Offiong changed his story and tried to persuade the DO that "in fact he was recruiting labour, not for the United Africa Company, but for 'his father's plantation at Akpabuyo near Calabar". ${ }^{110}$ Michael Offiong was sent to Eket prisonnot for beguiling or controlling representations in the minds of others but for "forgery and uttering false documents." It is not clear how long he was in prison-not long for sure - the DO was unaware that he had stumbled on one of the main recruiters, operating since the mid-1930s with a network of proxies, a delivery crew and a handful of large Spanish planters as regular clients. ${ }^{111}$ Within a few years of the incident at Okopedi, Michael Offiong alias Asuquo Bassey was back in Santa Isabel. He was the biggest recruiters based out of Calabar, with five canoes at his disposal, sixty rowers at his command. With a trail of forgeries and bribed officials in his wake,

\footnotetext{
${ }^{110}$ DO Eket to Supt. of Police, Aba, 24 November 1938, NAE, CALPROF 5/1/194; DO Eket to Resident, Calabar, 16 January 1939, NAE, CALPROF 5/1/194.

${ }^{111}$ Michael Offiong was a prominent name on an early list of "persons suspected of recruiting" when the traffic was mostly still being conducted on the backs of forged permits and colonial steamships. Commissioner of Police, Calabar to Agent, Elder Lines, Calabar, 4 June 1936, NAE, CALPROF 5/1/194; see Martino, 'Clandestine Recruitment Networks in the Bight of Biafra', 55-58.
} 
in a single day in December 1942 he passed on a hundred labourers to the police/labour office/planter 'combine' at Santa Isabel. ${ }^{112}$

For the British, the tout, was almost unanimously seen as a "modern successor of the slaver", capable of "any sort of roguery or deceit to cajole his victims". Even for the Franco-fascist colonial Spaniards "veritable slave-traders had been resurging in the twentieth century". ${ }^{113}$ The transference of this label left the British authorities in quandary, because they could not intervene through legal means. Touts treaded on fine lines and legal grey areas, they only became liable to punishment and penalties when they crossed a border out of Nigeria. Even when the British revamped their investigative surveillance and patrols with a directive to pursue and repress, the border state unfolding beyond the customs wharf and check-point outposts was being consistently outmanoeuvred. Fernando Pó's touts concealed many things but not themselves, as they were doing nothing illegal yet and so they could tout undisturbed at riverside markets and junctions, on one of the many thousands of canoes that travelled the many waterways that fed the Cross River.

While British officials said they were keeping a "strict watch" and "all illegal recruiters against whom evidence exists are prosecuted", they also papered over their own inadequacy by claiming that touts were "skilled in the art of evasion and arrests are rare." 114 Up until the 1938 the British "had a motor launch which was used to pursue" these "smugglers of human souls", but due to budget cuts this "service was stopped" for over half a decade, and so, as David Aworawo says, "the illegal traffickers had a field day". ${ }^{115}$ During this key spike in the canoe traffic, the "water police" forces were themselves only being "equipped with canoes". In 1939 there

\footnotetext{
${ }^{112}$ AT Santa Isabel, 8 December 1942, 'Relacion de los reclutadores que salen para Calabar', AGA, C81/15865, E-12; Michie, 'Labour Conditions in Spanish Guinea, Appendix C'.

${ }^{113}$ Orde-Browne, The African Labourer, 50, 54; Angel Yglesias de La Riva, Politica indígena en Guinea (Madrid: Instituto de Estudios Africanos, 1947), 219.

${ }^{114}$ Nigeria, Annual Report on the Department of Labour, Nigeria, for the Year 1943 (Lagos: Government Printers, 1945), 11.

${ }^{115}$ 'The Fernando Po Slave Traffic', The Nigerian Eastern Mail, Calabar, 25 February 1939; David Aworawo, 'Foreign Policy and the Travails of Nigerian Migrants in Equatorial Guinea, 1930-1980', Nigerian Journal of International Affairs 25, 2 (1999): 24-35, 26.
} 
were at least sixty canoes going to Fernando Pó on a regular basis. These canoes "generally sailed in convoys," "large convoys of canoes up to 20 in number" that gathered off-shore in this formation so that they could disperse in all directions if pursued by the "water police" who "proved to slow to intercept some large sea-going canoes which were said to have shown a clean set of flashing-paddles to the launch as they escaped." ${ }^{116}$ By the end of World War II the British tossed a small sea launch into the Cross River Delta, but should it "call upon the canoes to stop" practically all "escaped". The British considered the consequences of their inaction: "until a regular twenty-four hour patrol can be maintained it is likely that the flourishing illegal canoe traffic will persist." 117 Even district officers watched on as some of the "great canoes of the Niger and Cross River deltas" that could be up to "seventy feet long" and carry up to hundred people including "pull-a-boys, or paddlers" "put out to open sea and make the coasts of Fernando Po, at its nearest ninety miles away." 118

Colonial authorities struggled to follow and understand the organization of people smuggling, unless they caught someone red-handed on canoes near Fernando Pó they met with little success when implementing criminalization as policy. British justice found that "illegal recruitment" was "extremely difficult to prove". ${ }^{119}$ Leads sent in by family members who received letters from relatives in Fernando Pó did not result in convictions until the entire instrumentarium and theatres of proof could be mobilized in the local courts. In a case of fifty labourers from Ogoni and Eket working in Fernando Pó in 1935, not a single person could come back to court and the magistrate did "not accept SWORN STATEMENT" as there would have been no opportunity "for cross-examination." ${ }^{120}$ Nevertheless the six prosecutions for illegal recruitment to

\footnotetext{
${ }^{116}$ Supt. of Police, Calabar to Commissioner of Police, Lagos, 30 December 1938, NAE, CALPROF $5 / 1 / 194$.

${ }^{117}$ British LO (Evans), Calabar to Commissioner of Labour, Lagos, 23 September 1943, NAE, CALPROF 5/1/193; British LO (Evans), Calabar to Commissioner of Labour, Lagos, 18 September 1943, NAE, CALPROF 5/1/193.

${ }^{118}$ M. D. W. Jeffreys, 'Review of Water Transport. Origins and Early Evolution', African Studies 8, 2 (1949): 104-6, 106.

${ }^{119}$ Labour Officer (Lewis), Calabar to The Commissioner of Labour, Lagos, 6 December 1943, NAE, CALPROF 5/1/193.

${ }^{120}$ Commissioner of Police, Calabar to Resident, Calabar, 8 August 1935, NAE, CALPROF 5/1/192.
} 
Fernando Pó in the district courts of Calabar, Aba, Owerri, Ikot Ekpene and Opobo courts in 1938 rose to over a hundred in 1941, and even more in $1943 .{ }^{121}$ This sum in one year was more than double the total number of convicted cases of "child kidnapping" in Nigeria during the decade of the 1930s. ${ }^{122}$ Kingsley Mbadiwe, from the inner circle of Azikiwe political party, the NCNC, says: "In the early forties one of the commonest crimes in the Eastern Region was illegal recruiting: the Region was infested with people who by specious promises, induced other people to seek employment in Fernando Po". Nevertheless, the various laws that "deal with slave dealers" proved to be "ineffective as a deterrent" as there were "always others ready to take their place because the traffic was very profitable"; 123 "the canoe men undoubtedly are seeing that they can get $£ 20$ for each labourers they can contract". ${ }^{124}$ Touts could be arrested or change profession; but they were an open category, constantly supplanted by various members of a local commercial elite, by local fisherman, by traders from Dahomey, and even by former contract workers themselves. They only stopped operating once the planters got their labour in other places or through different means.

Kicks-Dadzie standing over the infamous landing cove in Santa Isabel, observed that "the canoe traffic goes on in great number, and if any one sees the number of canoes at Fernando Poo Bly-Beach, it will appear as if our Police Department are not doing anything to stop it." It "seemed [...] that the arrests and heavy fines are of no avail to the canoe people." 125

\footnotetext{
${ }^{121}$ Supt. of Police, Calabar to Commissioner of Police, Lagos, 30 December 1938, NAE, CALPROF 5/1/194; British LO (Lewis), Calabar to Commissioner of Labour, Lagos, 6 December 1943, NAE, CALPROF 5/1/193.

${ }^{122}$ Ugo Nwokeji, 'The Slave Emancipation Problematic: Igbo Society and the Colonial Equation', Comparative Studies in Society and History 40, 2 (1998): 318-55; 337, 342; Afigbo, The Abolition of the Slave Trade, 106, 90.

${ }^{123}$ Mbadiwe, 'Nigerian Workers in Po will be protected: Government promises', West African Pilot, Lagos, 26 August 1954; see Hollis R. Lynch, K. O. Mbadiwe: A Nigerian Political Biography, 19151990 (New York: Palgrave Macmillan, 2012).

${ }^{124}$ British VC (Lewis) to Supt. of Police, Calabar, 22 January 1945, NAE, CALPROF 17/1/277.

${ }^{125}$ Kicks-Dadzie to Resident, Calabar, September 1939, 'Confidential Report: Labour in Fernando Poo', NAE, CALPROF 5/1/195. Indeed, it seems the Spanish only realized their plans concocted in
} 


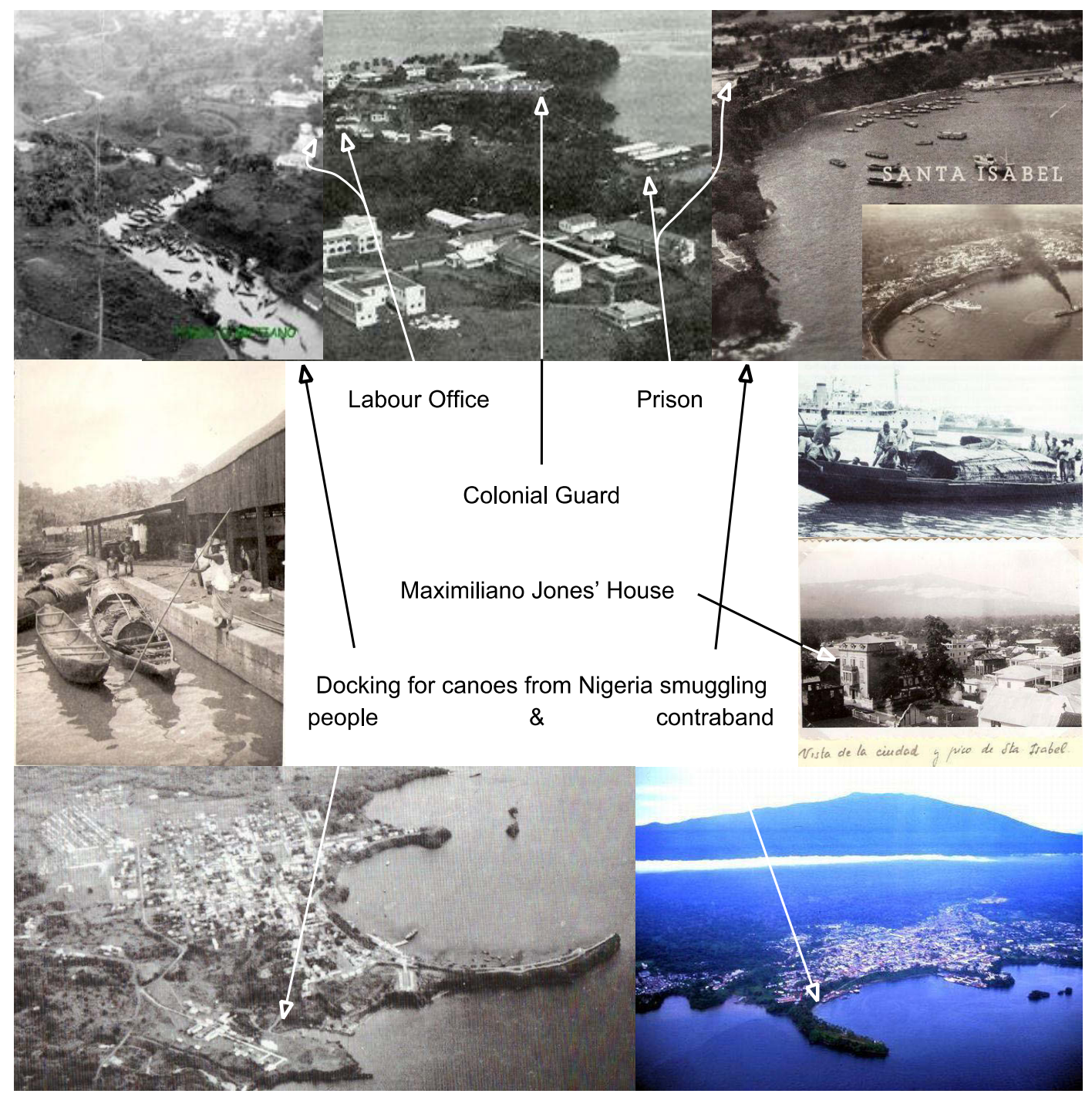

Figure 7 Aerial view of Santa Isabel with arrows to sites ${ }^{126}$

1780s during War War II: "Desde la ensenada de Sn. Carlos se va a la Costa con seguridad y en muy poco tiempo; mediante lo qual no seria dificil entablar en ella un comercio seguido, y obligar a los habitantes á que vinieren á Fernando Pó a vender sus esclavos en las grandes Canoas ó Piraguas de que usan.” José Varela, 1780, 'Descripción de la Isla de Fernando Poo', AGS, Estado, Legajo 7411, Documento 26.

${ }^{126}$ Images from http://bioko.net/galeriaFA/, searched 'cayucos' and 'Santa Isabel'. No permalinks. 


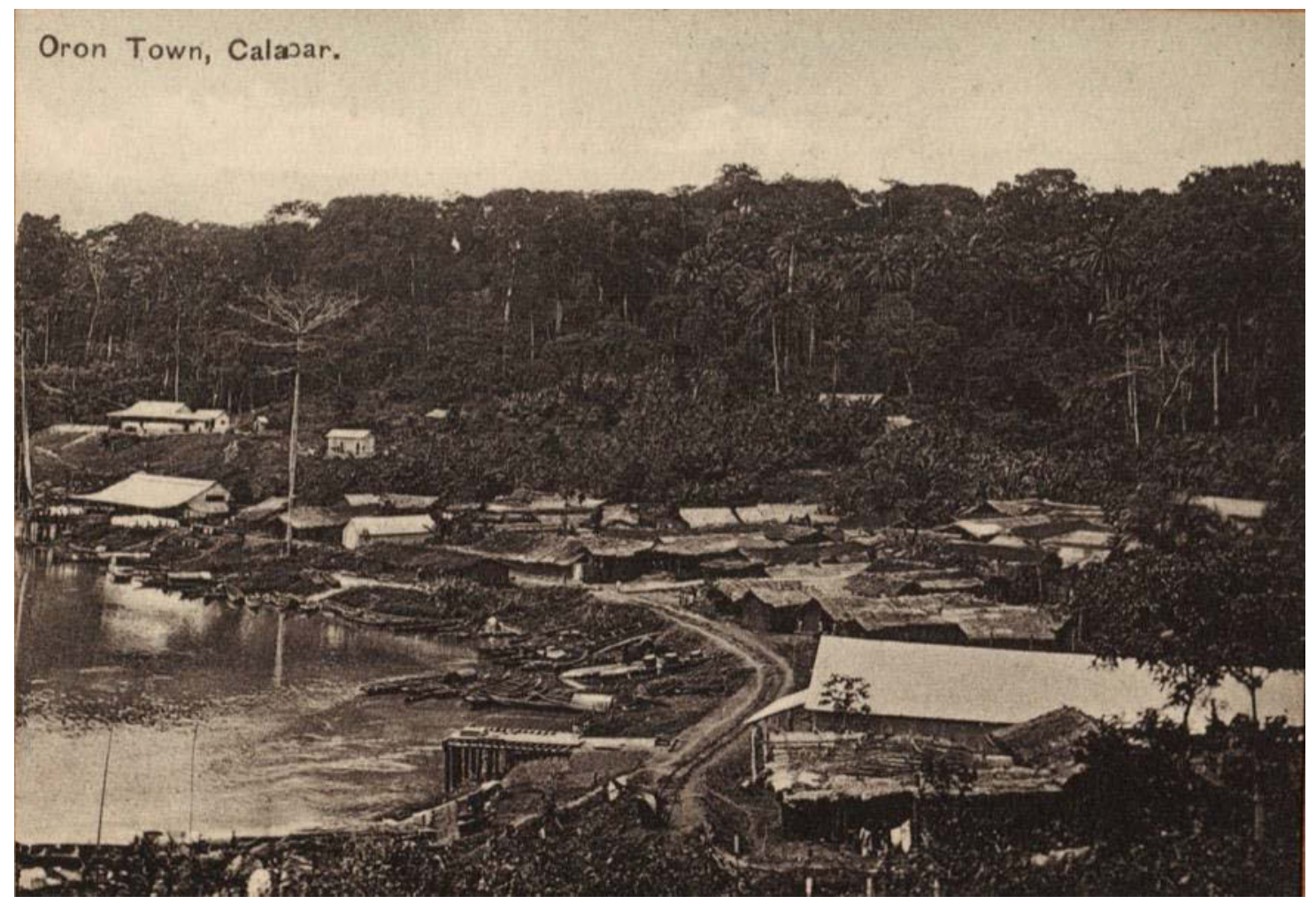

Figure 8 Oron Town, beyond the edge of the colonial pier ${ }^{127}$

Further complicating matters was the fact that the state was leaking heavily. The extent and complicity of the Nigerian police is not clear. S. Muyiwa an undercover policeman with a heart of steel shone a light on some of his colleagues, who he says had "decided that BRIBERY is the best means of living today at a laudable manner". The "inducement made the irresponsible recruiters to corrupt many a faithful servant of the Nigerian Government for many [had] been so degenerated that some of them serve as instruments to the Recruiters." ${ }^{128}$ The tout's central nodal point was the colonial boom town of Oron, though they did require the appropriately inaccessible delta island of Atabong, just upstream from Oron, to serve as "the port of embarkation and return of canoes that do the smuggling" with Fernando Pó. ${ }^{129}$

\footnotetext{
${ }^{127}$ Undated; likely early twentieth century, from SOAS, MMS, West Africa, Photographs, Box 1195B.

${ }^{128}$ S. Muyiwa to The Commissioner of Police, Calabar, 24 May 1936, NAE, CALPROF 5/1/194.

${ }^{129}$ British VC (Lewis) to Supt. of Police, Calabar, 25 November 1944, NAE, CALPROF, 17/1/277. Oron's commercial boom in the early twentieth century sprang forth when direct links to the "cargo boats from Liverpool" were, literally, cemented - through the mass requisitioning of forced labour to prepare the gravel for ports and drain the creeks after which "the merchants of Oron stated that trade
} 


\subsection{Language and Violence, Fernando Pó}

The sudden boom of the "canoe traffic and its inhuman circumstances" triggered the "most serious phase of the Fernando Poo labour question"-explains J.W. KicksDadzie, the first journalist to enter the island after it fell to the Francoists. KicksDadzie even interviewed the new Spanish Jefe de Policia, the police chief, Miguel Llompart Aulet, and implored him to "chase the wicked canoe traffickers out of the Island", to which Llompart flatly replied that he could "not possibly put a stop to it", as otherwise "they will not get labourers at all". If recruiters were con-artists then in Nigeria small sections of the colonially aligned voices of intellectuals, missionaries and officials were "pro-artists". Even Kicks-Dadzie praised the "highly scientific farming" of Fernando Pó large settler plantations as well as the Spanish colonial penal system and its "full" employment policy, as this allowed "no room for idlers, vagabonds and thieves". 130

The resident Methodist reverend, Ewart Shepherd also went out of his way to publicly praise the plantations, and their food rations and access to minimal health care. Shepherd praised the plantations as he watched as the "wholesale system of smuggling across in canoes" became "in vogue". "Dozens of these canoes land their human cargoes in a little haven close to Santa Isabel. They come out of the creeks between Calabar and Victoria and the Nigerian Government is powerless to prevent them." $" 131$ The chief Methodist in the region Frederick Dodds visited the island and was impressed by the façade of a fascist colony that in one stroke imprisoned "vagrants" en masse. During "the whole" of his month long trip in the spring of 1939, he "did not see a single ill-nourished" or "ill-clad" person. The Igbo and Ibibio

grew by leaps and bounds till" it "had risen to about three times that of Calabar". Percy Talbot, Life in Southern Nigeria: the Magic, Beliefs, and Customs of the Ibibio Tribe (London: Macmillan and Co., 1923), 256; Ofonagoro, 'An Aspect of British Colonial Policy in Southern Nigeria', 237.

\footnotetext{
${ }^{130}$ Kicks-Dadzie to Resident, Calabar, September 1939, 'Confidential Report: Labour in Fernando Poo', NAE, CALPROF 5/1/195; Special Correspondent [Kicks-Dadzie], 'Fernando Po Labour Conditions', The Nigerian Daily Times, Lagos, 13 July 1939.

${ }^{131}$ Rev. Ewart Shepherd, 'Nigerian Labourers in Fernando Po. Dr. Haden Guest Misinformed? Allegations of Slavery Cannot be Substantiated', West Africa, London, 13 May 1939; see also Leslie Haden Guest, London, to Sec. of State for the Colonies (MacDonald), 20 February 1939, TNA, CO 554/119/5.
} 
speaking Dodds did however find the courage to "condemn" the means by which "much of the labour for the island is now being recruited. There is a constant stream of canoes filled with Nigerians, many of whom have been lured into taking the passage under promise of being taken elsewhere."132

Putting the middlemen in the crossfire, indulging projections of unwholesome and always suspect 'middlemen' central to a Euro-Christian worldview, displaced and mystified the actual lines of solidity making up recruiting assemblages, the range of institutionalized imperial templates and legal grey areas that gave recruiting techniques their consistency and reach. In Fernando Pó, amongst planters "the feeling [was] very strong against these middlemen recruiters", because their commissions were out of regulatory reach. ${ }^{133}$ Some key British officials in the 1930 s - the Governor in Lagos, Bourdillon, and the British Consul, Twigge Molecey for example-foregrounded not only a vocabulary designed to demonize mediators but also one that accused the victims themselves of backtracking or "changing their minds": On hearing the stories of those "falling into the hands of the slave-dealers", they would say that "the 'slave dealers' have little or no difficulty in obtaining persons who are willing to go with them to Fernando Po, but the latter after 6 months try to abscond as they naturally miss their freedom and are unaccustomed to hard work."134 Some kidnapped workers too blamed themselves, as Ekpe Eyo said: "it was I who looked for money hence let this happen to me". ${ }^{135}$ But asking any of the labourers on Fernando Pó, they would have told you that there is a world of difference between a peddler and an enforcer.

\footnotetext{
${ }^{132}$ Dodds, July 1939, 'Notes on Visit to West African District, February to June 1939', SOAS, MMS, MMS/Special Series/Notes and Transcripts/FBN 1 (fiche 15-17); Rev. F.W. Dodds, 'Nigerian Labourers in Fernando Po', West Africa, London, 24 June 1939.

${ }^{133}$ Comissioner of Police, Calabar to Inspector General of Police, Lagos, 22 May 1936, NAE, CALPROF 5/1/194.

${ }^{134}$ Commissioner of Police, Buea, Cameroons to Senior Resident, Calabar, 31 January 1934, NAE, CALPROF 5/1/192; British VC (Twigge-Molecey) to Resident, Calabar, 30 November 1938, NAE, CALPROF, 5/1/194; Governor of Nigeria (Bourdillon), Lagos to Sec. of State for the Colonies (MacDonald), London, 15 February 1939, TNA, CO 554/119/5.

${ }^{135}$ Ekpe Eyo, Santa Isabel to Eyo Ubon, Afaha Atai, Uyo Division, Calabar Province, 2 September 1938, NAE CALPROF 5/1/194; [original in Ibibio in NAE CALPROF 5/1/195].
} 
Actual coercion and violence resided in the ends not the means, subsisting in the structure of imperial contract law. Deception, to set up a ruse, is eminently grounded in communication. But as Walter Benjamin says in his essay, the Critique of Violence, "verbal arrangements fundamentally exclude violence". ${ }^{136}$ To beguile is to steal through language, but on arrival one is at a loss only if one is stopped from leaving again. If they could have left relatively unscathed, panya would have simply been dismissed as a waste of time. The future braceros were at no point accosted or assaulted up until the point and no sooner than when they refused to sign a contract at the Curaduria.

Though the drift of violence could certainly start on the canoe when communication stopped. The "recruiters did not always stop at promises of work" as "all too often a man who had to make a journey along the coast" would find "that the canoe was putting to sea: if he asked where it was going, he would be told that it was bound for Fernando Po, and that if he didn't want to go there he could jump overboard". On a canoe there would be barely sufficient reason for an accusation of false imprisonment, a violation of habeas corpus; though definitely of reckless endangerment, as the canoes, several a year, "from being overcrowded often upset, with the loss of everybody in them." ${ }^{" 137}$ Kicks-Dadzie even met and even photographed "a batch of kidnapped labourers who were conveyed by canoe just a few weeks before" who told him: "'Do all you can to stop the canoe traffic for majority of us had perished in the Sea',"

\footnotetext{
${ }^{136}$ Evidenced by "the impunity of the lie" that was exempted "from punishment in Roman and ancient Germanic law” and for that matter Nigerian colonial law. Benjamin, 'Critique of Violence', 245.

${ }^{137}$ Mbadiwe, 'Nigerian Workers in Po', West African Pilot, Lagos, 26 August 1954.
} 


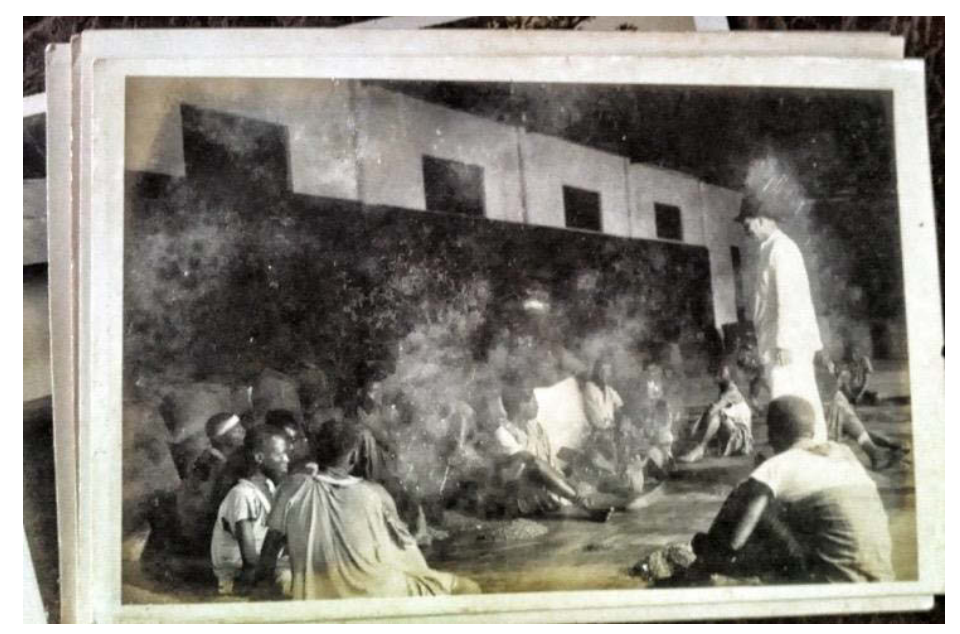

Figure 9 "The Kidnapped labourers referred to in my Report at Livani Farm"138

After describing the distressing daylong passage on the ocean-going canoe, Ekpe Eyo relates how on firm ground in Santa Isabel's Curaduria he "argued that I will not stay, but they said that I would be sent to prison until after two years then we go."139 Anyone "lured to the Island [had] little chance of avoiding entering into a contract once they are there." 140 The contract on the island was still mostly what Orde-Browne called of the "old type" or a "legal trap for the unwary native." ${ }^{141}$ The order of contracts was not very elaborate nor did it provide much room for manoeuvre, it was simply an obligation to 'obey' it as law.

On Fernando Pó it was not only that varying degrees of corporal punishment were permitted and used by both employers and the Spanish police or that there elaborate penal sanctions for breaking or refusing a contract - these were in full force until independence in 1968 - but that 'transgression' was a default. Arriving on the island without appropriate paperwork or connections, landed one a bracero contract, with a

\footnotetext{
${ }^{138}$ Kicks-Dadzie to Resident, Calabar, September 1939, 'Confidential Report: Labour in Fernando Poo', NAE, CALPROF 5/1/195; This image and his series of unique photographs from his report are available in his report.

${ }^{139}$ Ekpe Eyo, Santa Isabel to Eyo Ubon, Afaha Atai, Uyo Division, Calabar Province, 2 September 1938, NAE CALPROF 5/1/194; [original in Ibibio in NAE CALPROF 5/1/195].

${ }^{140}$ Governor's Deputy, Lagos to Sec. of State for the Colonies (MacDonald), London, 23 August 1939, TNA, FO 371/23171.

${ }^{141}$ Orde-Browne, The African Labourer, 70.
} 
forced signature on site. If "a labourer declined to accept the contract placed before him he can be treated under the existing Spanish laws, as a rogue and a vagabond", meaning jail-time with penal labour until forcibly contracted. ${ }^{142}$

The Spanish policy of having "anyone who arrives in this port, as soon as they disembark present themselves at the Curaduria", and of "forcing vagos without employers" to be put up "for contract in the Curaduría" had existed since 1910. This forced employment had obviously been "directed to the benefit of la agricultura in these lands, in light of the scarcity of brazos". ${ }^{143}$ These penal sanctions guaranteeing forced employment were the structural precondition of the extension of the recruitment space of Fernando Pó's plantations as they waddled around the Gulf of Guinea summoning and beckoning in its wake. No other medium or presupposition sustained and underpinned these panya recruitment operations and techniques. There were no labour mobility without recruiters or contracts, or to put it generally, there was no circulation without meditation and inscription.

\subsection{Conclusion}

The word crimp has the same etymology as 'crook', whose specialty was not only deviating from the regulations they were generated by, but also to deploy manipulative capacities to fold someone into line by twisting wills. Crimps were called upon or generated whenever military or commercial front lines in unpopular destinations needed replenishments in periods of acute labour scarcity. But their linguistic techniques were effective only in bursts. In the early modern British Empire, spirits' modus operandi were popularly imagined to consist of "diabolic cunning and assiduity"; "hordes" of "monsters" and "demons" "infest the metropolis", “deceiving" through "persuasion with 'allurements and deluding falsities"”. "Men-stealers, termed otherwise Spirits or Kidnappers, whose whole employ is to collogue and seduce indigent, ignorant Souls [by] making Golden

\footnotetext{
${ }^{142}$ British VC (Michie), 28 February 1941, 'Labour Conditions', TNA, FO 371/26908; Osuntokun, Equatorial Guinea Nigerian Relations, 32.

${ }^{143}$ GG, 25 June 1910, ‘Presentación trabajadores', in Miranda Junco, Leyes coloniales, 401.
} 
promises of things never likely to come to pass".. ${ }^{144}$ Their techniques and the imaginary used to describe such techniques are very consistent over the centuries. Spirits, even if they become known or are dispelled reappear elsewhere in different guises, their presence and abilities unfolding with new faces and accents. Labour touts were the afterlives of spirits, whose technique were refined before the abolition of the slave trade and before the establishment of the Manichean legal apparatus of imperial European powers that polarized divisions between 'free' and 'unfree'. Instead of establishing time-line of abolitions and transitions or engaging in the matching or dispelling of orders of similitude along a temporal axis, a completely different pictures emerges within a spatial and global frame.

Abduction could be experienced as a beam of shock and removal to the unknown, but also the displaced result of encounters plagued by an awry two-facedness of snares and lures. This range was considered by many British abolitionist officials in an imperial world to be a "species of slavery or kidnapping". ${ }^{145}$ Those naming the practice sprinkled their terms with important prefixes generating a parallel whose gap or degree of similitude was uncertain. This uncertainty, along with the intensely localized nature of the practice, is one of the reasons why such recruiting techniques generated so many ambiguous and slang terms to designate itself: shanghaiing, blackbirding, to be barbadosed, trepanned, phuslaoed or spirited by agents, middlemen, contractors, brokers, enticers, sea-pimps, land-sharks, spirits or crimps in the British Empire, arkatis in Bengal, ${ }^{146}$ snakes and chu chay tao or pig brokers in southern China, ${ }^{147}$ the blackbirder of the South Pacific, ${ }^{148}$ enganchadores in Latin

\footnotetext{
${ }^{144}$ Thomas Carlyle, 'Diderot', in The Foreign Quarterly Review (London: L. Scott, 1833), 137; J. Stevenson, 'The London 'Crimp' Riots of 1794', International Review of Social History 16, 1 (1971): 40-58, 53; Wareing, "“Violently Taken Away or Cheatingly Duckoyed", 6.

${ }^{145}$ Laurence Brown, “'A Most Irregular Traffic”: The Oceanic Passages of the Melanesian Labor Trade,' in Many Middle Passages: Forced Migration and the Making of the Modern World, eds. Emma Christopher, Marcus Rediker, and Cassandra Pybus (Berkeley: University of California Press, 2007), 184-203, 185.

${ }^{146}$ Tirthankar Roy, 'Sardars, Jobbers, Kanganies: The Labour Contractor and Indian Economic History', Modern Asian Studies 42, 5 (2008): 971-98, 971.

${ }^{147} \mathrm{Hu}-$ DeHart, 'La Trata Amarilla’, 169.
} 
America, ${ }^{149}$ headmen in colonial British West Africa ${ }^{150}$, or runners in South Africa; ${ }^{151}$ an "erratic" labour market whose most widespread and consistent feature was "knavery", being "cajoled by plausible touts". 152

Panya shares specific junctions with a global labour history, where the same pattern of recruitment is found, lasting also for one to several decades, and containing the same constant spatial shift; whether in the 1760s between Rhineland and Pennsylvania; between London and Barbados or Virginia in the 1640s, during the Napoleonic Wars across the United Kingdom and parts of Europe in the 1790s; across the early nineteenth century American seaboard, first east then west; in the 1840s around many places, including the Windward coast, the port towns in the Bay of Bengal and Xiamen and Macau, late nineteenth century Oceania, between Vanuatu, Solomon Islands or New Guinea and Queensland, Fiji and Peru. The medium-term persistence of touts has been amply demonstrated for early twentieth century Southern Africa, shifting at the "junctions" between Mozambique, Southern Rhodesia, and the Transvaal. There the creative process of "fraud and misrepresentation" by unlicensed “"rapacious labour touts and criminal gangs"”, who made "promises which they did not intend to keep", were spoken of by local administrators and academics as having "degenerated into "nothing more or less than a sort of slave trade". ${ }^{153}$ These

\footnotetext{
${ }^{148}$ Gerald Horne, The White Pacific: U.S. Imperialism and Black Slavery in the South Seas After the
} Civil War (University of Hawaii Press, 2007), 43.

${ }^{149}$ David Spener, Clandestine Crossings: Migrants and Coyotes on the Texas-Mexico Border (New York: Cornell University Press, 2009), 99.

${ }^{150}$ Carolyn Brown, "We Were All Slaves": African Miners, Culture, and Resistance at the Enugu Government Colliery (Portsmouth: Heinemann, 2003); Cassandra Mark-Thiesen, "The "Bargain" of Collaboration: African Intermediaries, Indirect Recruitment, and Indigenous Institutions in the Ghanaian Gold Mining Industry, 1900-1906', International Review of Social History 57, S20 (2012): 17-38.

${ }^{151}$ Jeeves, Migrant Labour in South Africa's Mining Economy, 87-90.

${ }^{152}$ Orde-Browne, The African Labourer, 74.

${ }^{153}$ Murray, "Blackbirding” at "Crooks" Corner', 382, 389, 380; citing District Commandant, South African Police, Zoutpansberg District (Kirkpatrick) to Secretary, SAP, Johannesburg, 18 October 1912, CAD [now SAB], NA 2,5766/2(2); also cited in Alan Jeeves, 'Over-Reach: The South African Gold Mines and the Struggle for the Labour of Zambesia, 1890-1920', Canadian Journal of African Studies 17, 3 (1983): 393-412, 404, 407; Andrew MacDonald, 'Forging the Frontiers: Travellers and Documents on the South Africa-Mozambique Border, 1890s-1940s', Kronos 40, 1 (2014): 154-77, 
"unlicensed freelancers reaped huge profits", in part because they "used all sorts of tricks and ploys to ensnare unwary Africans and to smuggle this precious human cargo across the Limpopo."

Murray draws an intriguing portrait of an Afrikaans man, a former soldier, Cecil Barnard-local alias "Bvekenya" or "the drunk", "the one who swaggers as he walks"-who he says became "Africa's leading illegal recruiter". "Barnard and his companions practically monopolised the labour recruitment of Shangaans" living in southern Zimbabwe. In "1917 alone, Barnard's best year, he single handedly recruited 3,250 Africans illegally and 'safely smuggled them past Portuguese and Transvaal police alike"”. While Barnard was an imposing figure, Fernando Pó recruiters operating out of Calabar were close on his heels, smuggling up to 10,000 people a year into the island - though Calabar's touts were markedly less violent and less white. While gun-toting predatory recruiters do make an alarming appearance on the South African frontier - as Barnard and a dozen others "resorted to ambushing and hijacking labour from careless rivals"-an official South African WNLA labour recruiter in Southern Rhodesia observed that " no force is used and these Shangaans so far from objecting are very willing to go with Barnard' [...] 'They go to the Rand Mines with absolute regularity. Of course this is illegal but the natives don't object'."154

In the African history of colonial labour regimes-for very good reasons, but inadequate ones in the last instance-recruiters figure as callous and hazy agents. The details of delicate, multi-layered, contradictory and plainly brutal processes are often

157; Patrick Harries, Work, Culture, and Identity: Migrant Laborers in Mozambique and South Africa, c.1860-1910 (Portsmouth: Heinemann, 1993), 115.

\footnotetext{
${ }^{154}$ Murray, “"Blackbirding” at "Crooks” Corner', 374, 380, 389, citing Cecil Barnard and Thomas Victor Bulpin, The Ivory Trail (Cape Town: Books of Africa, 1967), 164-6, 172-3; see also Jeeves, Migrant Labour in South Africa's Mining Economy, 153-83; Jeeves, 'Over-Reach', 402, 405. By 1915 these "unlicensed touts" and "white bandits", often offered "their services to southward moving migrants frequently at gunpoint." Of the "illegal recruiters, three of the worst operated together and constituted a notorious gang, well known along the entire Mozambique border from the Limpopo to Melsetter far to the north. Charles Diegel was a German national; one accomplice, Barnard, was an Afrikaner; and the other, Roux, was described by' the authorities as a 'Transvaal half-caste'. Repeated police patrols failed to pick up this unwholesome trio but found plenty of evidence of their work. The gang was armed, of course, and had thoroughly cowed the local population by burning kraals and systematically flogging and assaulting the inhabitants. There had been several murders in the area."
} 
lost within the condemnatory caricatures with which recruiters are painted with in labour history. Summarizing the labour history literature on Southern Africa, Frederick Cooper posits a tripartite form of labour mobilization, a kind of 'the good, the bad and the ugly': a free labour saddled with needs but unencumbered by encounters except with employers; a plainly forced, state-led uprooting of indigenous people; and the suspect enticing violence of recruiters spread out along extensive junctions and thousands of kilometres. In "the gold mines of Southern Rhodesia", an early "period of highly coercive recruitment" orchestrated by uniformed colonial officers, gave "way by the early 1920s to a situation where Africans came themselves to the mines, while recruiters devoted their dubious attention to getting labour for white farmers." The "dubious" recruiters supplanted official agents by seemingly reverting to a kind of slave trade by deploying "methods [that] were sometimes closer to kidnapping."

"Officials knew that the fraud and misrepresentation which inevitably accompanied competitive recruiting frequently caused disturbances in the countryside, to the eventual detriment of the overall supply," so in their own South African districts they tried to "eliminate some of the cruder forms of exploitation and fraud which had prevailed in the 1890s." However, "north of the Union's borders, no such controls operated at all." And in this sense the planters of Fernando Pó can be compared to the Witwatersrand's 'Randlords' and the inter-colonial pattern of labour recruitment they both came to heavily rely on for half a century. Between the 1890s and the 1920s and even into the 1940s "recruiting for the gold mines from beyond the Limpopo became an elaborate, highly organised business. For most of this period it belonged to unlicensed touts, and their black 'runners." "Although economically weak compared to the mining groups, these independents were able to dictate the terms on which labour was recruited for many years." Even when this 'phase' had supposedly been displaced though a bilateral and regulated arrangement with the Portuguese in

\footnotetext{
${ }^{155}$ Cooper, Decolonization and African Society, 44; For coercive state-led recruitment see, Vail and White, Capitalism and Colonialism in Mozambique; David Johnson 'Settler farmers and coerced African Labour in Southern Rhodesia, 1936-46', The Journal of African History 33 (1992): 111-28.
} 
Mozambique, the miners in the Rand "routinely consorted with the unlicensed independents in their endless search for reliable supplies" of labour. ${ }^{156}$

The economy of deception in the recruitment of indentured labour is usually attached to "force" by its analysts: blackbirding was "dishonest and violent", spiriting was "fraudulent and coercive", it meant being "violently taken away or cheatingly duckoyed", "either through deception or direct violence", "victims were kidnapped, tricked by offers of good jobs"; "all forms of persuasion and coercion were employed" by recruiters who painted "a rosy picture" and the "poor workers often fell prey to these ploys", finding themselves becoming "victims of empty promises", all in all, a kind of "enticement/kidnapping". ${ }^{157}$ The different segments of a recruitment trajectory are often collapsed in the category of crimping: the use "persuasion, swindling, or coercion". The same range of conflationary vocabulary is used in twenty first century definition of "trafficking in persons". ${ }^{158}$ Indeed already in 1925 the Anti-Slavery and Aboriginal Protection Society decided on a "broad principle" when deciding "what practices may be said to-day to amount to modern slavery", namely "any system in which force or fraud are exercised to secure control over the labourer for private ends". ${ }^{159}$ This double bind of language and violence is connoted in panya, but logically they occur apart, in place and in time.

\footnotetext{
${ }^{156}$ Jeeves, 'Over-Reach', 395, 401, 410. "The old ways died hard. In 1947, a syndicate of blackbirders was caught in the Waterberg, impersonating police and waiting in hideouts along the Crocodile River." MacDonald, 'Colonial Trespassers', 271, 287.

${ }^{157}$ Martin A. Klein, Historical Dictionary of Slavery and Abolition (Lanham: Scarecrow Press, 2002), 76; Wareing, "Violently Taken Away or Cheatingly Duckoyed”, 1; Brown, “"A Most Irregular Traffic",, 194; Miers and Roberts, "The End of Slavery in Africa', 21; Ravi Raman, Global Capital and Peripheral Labour: The History and Political Economy of Plantation Workers in India (London: Routledge, 2010), 100.

${ }^{158} \mathrm{http}$ //www.dictionary.com/browse/crimp; 45. See esp. conclusion of McKeown, Melancholy Order, 349-69.

${ }^{159}$ Joel Quirk, 'Defining Slavery in All Its Forms: Historical Inquiry as Contemporary Instruction', in The Legal Understanding of Slavery, ed. J. Allain (Oxford: Oxford University Press, 2012), 253-78, 257, citing Temporary Slavery Commission, 28 May 1925, 'Communication of May 20th, 1925 from the Anti-Slavery and Aborigines Protection Society, London', League of Nations Archive, Geneva, $\mathrm{L} / 28029 / 23252$.
} 
The pattern of the technique is clear, first the trick then the force, first the farce, then the tragedy. The first segment is referred to with endless synonyms for deception, that in comparison to "force", borders on the obscenely light-hearted, almost playful, infantilizing and incredulous - to trick. However, the 'trick' as vector of instrumental language for the commodification of the desire, is an axiomatic, consistent and creative capitalist praxis, present also in the grease that wheeled imperial labour recruitment. Touts were one of the symptoms of the expansion of the internal limits of capitalism and its arenas of operation, every day commercial dealings with opaque others, containing hazards and seductions. Out of the imperial establishment of port towns and transport junctions, the global depression that caused palm oil prices to crash, colonial tax hikes and the localized monetization of social life, came the crushing promise of a lift held out by the outside world and the need to draw on it. The medium for drawing out desire and representation, its imaginaries and routes, were touts. 


\section{Touts vs. Despots: Dash or the Contradiction of Bonding Labour with Money}

Dash in Fernando Pó's pichinglis, as in many of the pidgins spoken across West Africa, meant simply the gift as an ancillary component to an exchange. What happened to the dash when it was welded onto the indentured labour contracts on Fernando Po? It became something like a wage advance. In the literature on colonial and post-colonial unfree labour, the dash or the wage advance are seen as the essential ingredient to create the conditions of peonage ${ }^{1}$ and debt bondage. ${ }^{2}$ Instead of being drip-fed, wages in capitalist unfree wage labour are said to come in lumps in order to "immobilize" or "deproletarianise",3 workers, in effect to pay them much less than if they would have been hired continuously as free labour. The dash-wage-advance was not formally, in the eyes of colonial contract makers, an advance on wages but an excess that created an ideological imaginary and material effect: a sum of money to be paid off in labour, which is to say it created the fiction of a "debt". The depiction of "wages as loans, is simply a device to control labour in conditions where the competition for labour is likely to drive up the bargaining power and wages of

${ }^{1}$ In the non-revisionist Latin American historiography debt peonage appears as the core of non-slave labour control. The canvas is discontinuous and takes place in specific pockets until wherever popular twentieth century revolutions put a halt to it, from southern Mexico (especially Yucatán, Tabasco and Chiapas), the coastal plantations of Peru in the 1860s to the Peruvian Amazon during the rubber boom of the 1890s. This work really begins with Silvio Zavala, 'Origenes Coloniales Del Peonaje En Mexico', El Trimestre Económico 10, 40 (4) (1944): 711-48. For Peru, see, Peter Blanchard, 'Recruitment of Workers in the Peruvian Sierra at the Turn of the Century-Enganche System', InterAmerican Economic Affairs 33, 3 (1979): 63-83; Scott, 'Peasants, Proletarianization and the Articulation of Modes of Production: The Case of Sugar Cane Cutters in Northern Peru, 1940-69'. On the use of debt to trap free labourers in Belize and Guatemala see Bolland, 'Systems of Domination after Slavery'.

\footnotetext{
2“Advances lead to bondage when they capture a labourer into a debt trap, are accompanied by harsh labour conditions and exploitative wages, are buttressed by violence and coercion, and curtail a worker's bargaining power and ability to access alternative employment. Even if voluntarily entered, debt can lead to forms of bondage that remove workers' control over their own labour and tie them into bonds they can no longer escape." Carswell and De Neve, 'From Field to Factory', 433. See Brass, Towards a Comparative Political Economy of Unfree Labour, 14, 244-56.
}

${ }^{3}$ Yann Moulier Boutang, De l'esclavage au salariat: économie historique du salariat bridé (Paris: Presses universitaires de France, 1998); Brass and Bernstein, 'Introduction: Proletarianisation and Deproletarianisation on the Colonial Plantation', 17. Indeed, debt was a reason for limiting mobility even for the non-braceros on Fernando Pó who could not leave the island if they were indebted to the treasury for taxes and unpaid fines. 
workers. It is a legal or pseudo-legal fiction used by employers to manoeuvre workers into a system of forced labour (which is still wage-labour) or contain their mobility". 4

The literature on debt bondage has widely and consistently argued and theorized that excess wage advances or large sign-on bonuses that do not get deducted from the official wage, are a way for capitalist employers to mask and justify the further exploitation of labour through the language of conditional gifts and credit-and-debt. The academic literature does not obfuscate this relationship, they, like the workers consider a wage to be what you get paid for work, irrespective of how it is ideologically differentiated by employers. The dash was not a 'gift' or a 'bonus' of incentive and paternalist reward, able to be thought of as its own category. This is almost the only idea that the leading conceptual scholars of unfree labour, Jairus Banaji and Tom Brass agree on. Any other subdivision or differentiation using the emic categories of employers are rooted in an ideology that serves to obfuscate the labour-capitalist relationship particularly when it takes an 'unfree' form.

Scholars have looked through this obfuscation in order to ascertain what benefits accrue to the employers who frame their wage-payments in ideological terms of debts; first, of all it enables employers to make the moral arguments of outstanding debt in order to extend contracts in a situation of labour scarcity; second, if money is bulked or injected at the outset it becomes effectively a 'credit-wage' or a type of debt-slavery: that is, workers are obliged to pay back that money through labour. When employers gave a dash they did not think of it as an unconditional gift nor did they want workers to pay them back their 'gift' in cash, because this would annul the ongoing labour relationship or bond, and eliminate the possibility of extending the time workers are subjected to paying this back through labour: this is the elementary operation of debt bondage.

In Fernando Pó the dash engendered but also contradicted this arrangement of debt peonage. The dash was demanded outright by reengaging workers and relayed by a set of unruly resident touts and they turned it from the pervasive lynchpin of most historical constellations of indentured labour and debt peonage into the key that

${ }^{4}$ Banaji, 'The Fictions of Free Labour', 87. 
incited a dispersed counter-movement of escalations and desertions that threatened the colonial order of planter power with collapse in the 1950s. The place of the dash outside the contract, the timing of its payments and its outright negotiation, carried with its own distinctive gifty code that generated both new forms of exploitation and resistance. It was the conditions of this very bondage, the attempts at "attachment" by competitive employers vying for scarce labour - an overriding principle in the history of modern imperial capitalism - that allowed a distinctive and radical form of workers' resistance to unfold.

Contracted braceros had their official wages withheld until the very last day of a contract to ward off desertions and make the accounting of deductions easier. But for those signing onto a second contract there was also a supplementary unregistered payment at the outset-immediately preceding a further uninterrupted and irrevocable two-year bind. This bind could be doubled and extended, "because the system of wage advances over and above the salary means that the workers are frequently indebted". This gave the planters in the "always present conditions of labour scarcity and reticence a way to oblige braceros to work off their debts" by signing on to a "further contract". ${ }^{5}$ However, the "casually authoritative way" this Spanish colonial economist refers to the device of debt in Fernando Pó's hiring arrangements should cause a pause, not only because it skims over the many moments of actual violence within the "deceptively transparent" relation of peonage, but because it papers over the history of resistance generated by those who demanded the advance. ${ }^{6}$

Why did tens of thousands of labour migrants indenture themselves to the planters in Fernando Pó in the decades after the Spanish Civil War? H. Rylands, a British colonial officer stationed in Owerri, where the mostly Igbo braceros were from, says he had "heard all about the 'evil' conditions of Nigerian labourers in Fernando Poo from those who [had] previously been" there. In 1947 he was dispatched to the island as Vice Consul and concluded that the "illiterate candidate for the Fernando Poo

${ }^{5}$ Velarde Fuentes, 'Problemas de Empleo', 174.

${ }^{6}$ Taussig, Shamanism, Colonialism, and the Wild Man, 62. 
labour market knows more or less what to expect". ${ }^{7}$ The "candidates" could expect openly practised police torture and overseers committing manslaughter with impunity: so why did the majority stay on for a second and sometimes a third contract, but almost never a fourth? And why were the informal modes of payment of these subsequent contracts a remarkable instance of a vast counter-movement that brought the order of planter power to its knees? The answer to all three is dash.

The "peculiarity of the process of contracting labour" writes a Spanish planter in the 1940s, "is the age-old custom of giving advances to the braceros the moment a contract is effected". ${ }^{8}$ The Spanish called this advance regalo or prima-a present or bonus at the outset - while the Nigerian labour migrants on Fernando Pó, most of whom learned to speak Pidgin on the island, called it dash. In a first instance, the dash of dash-peonage was simply the advance made possible by long-term bondage contracts. In principle and as a matter of policy indentured labour contracts tended to enshrine "bondage in exchange for advance payment". 9 The braceros who demanded and invariably received this "very substantial inducement to recontract" found themselves between contracts already on the island. ${ }^{10}$ The dash was not reducible to something else - to an extension of credit used to uproot or to cover initial transport costs. The dash, an axiom of West African commercial life, had its own autonomous trajectory and political meaning. The dash was not contained by a debt deployed to involuntarily retain and direct migrant labour. The dash was not "anchored", as Jane Guyer would say, to commercial exchange even though it was generated by and constituted from the same materials. As the dash became inextricably part of the peonage contracts on Fernando Pó it produced its own sociality and space of renegotiation that riddled the plantations with a contradiction that came to destroy their viability. Recruitment techniques involving debt generated a two-way movement, a mobile form of submission and subversion, a friction that both enabled

${ }^{7}$ British VC and LO (Rylands) to Commissioner of Labour, Lagos, 8 January 1947, NAE, CALPROF $17 / 1 / 278$.

${ }^{8}$ Cámara (de Sola Galvez) to Curaduría (Llompart Aulet), 17 October 1949, AGA, C-81/08130, E-3.

${ }^{9}$ Stanziani, 'Beyond Colonialism', 71

${ }^{10}$ British VC (Lewis), to British Embassy, Barcelona, 5 July 1946, 'Labour Conditions in Fernando Poo', NAE, CALPROF 17/1/278. 
and undermined imperial plantation economics. Without credit-wages, the ancillary dispensing of lump sums, the plantations on Fernando Pó would have fallen apart; none of the Nigerian braceros would have stayed on the island. At the same time, plantations repeatedly almost fell apart because of these same braceros continuing to sign contracts under informally renegotiated advances.

Rather than being a predictable fold in the interplay of domination and subordination, the dash was a slippery and unwavering trigger, heralding an 'unstable' promise of "plenitude" and producing a plethora of tactics for "unsanctioned" wealth. ${ }^{11}$ As I will go on to detail, with every contract came a higher dash, whether braceros acquired it after deserting or not. This double excess - the inherently inflationary, the incitement to escalation - is the principal social dynamic in Marcel Mauss's The Gift. This fundamental instability and potential for reversibility is an underestimated counterforce in studies of debt bondage. The notion that wage advances are a sort of poison of entrapment lingers within scholarly and popular conceptual frames-Das Gift, after all, means poison in German. ${ }^{12}$ This is, as I will be trying to argue, misleading, because the dash wielded by the bonded braceros was a show of their creative and collective power.

Historians and anthropologists continuously underline the ubiquity of debt in the creation of bonded labour. The entire premise and effectivity of the wage-veiled-ascredit, for example the "girmit (agreement) money" in the tea plantations of colonial Assam, was that it was so high that it become an unpayable debt, leaving workers unable to walk away. ${ }^{13}$ The economic argument made in the literature is that, paradoxically, the initial ability to choose employers in the context of a labour scarcity allowed mobile workers to demand high advances which subsequently led

\footnotetext{
${ }^{11}$ Guyer, Marginal Gains, 16; Berry, 'Stable Prices, Unstable Values', 308; Roitman, Fiscal Disobedience, 83-4. For advances in a framework of credit and consumption see Deborah James and Dinah Rajak, 'Credit Apartheid, Migrants, Mines and Money', African Studies 73, 3 (2014): 455-76, 462; Isabelle Guérin, 'Bonded Labour, Agrarian Changes and Capitalism: Emerging Patterns in South India', Journal of Agrarian Change 13, 3 (2013): 405-23.

${ }^{12}$ Mauss, The Gift, 81; Derrida, Given Time, 12.

${ }^{13}$ Behal, 'Power Structure, Discipline and Labour in Assam', 164; De Neve, 'Asking for and Giving Baki’, 387; Prakash, Bonded Histories, 169, 142.
} 
them to become "attached" unfree labourers. Also somewhat paradoxically, is that advances benefitted employers in so much as they wound up paying bonded labourers much less in total wages than if they had hired them at 'free' or "normal market clearing rates". ${ }^{14}$ Wage advances have also been thought to index a modicum of worker "bargaining power" as well as various degrees of patronage and dependency - arguments made especially in the so-called "revisionist" Latin American literature on debt peonage. ${ }^{15}$ The braceros on Fernando Pó, as elsewhere, were the "initiators of habilitación"- the cash advance - they "activated" it and so they were clearly "far from the passive victims of domineering patrones [employers] in need of cheap labour". ${ }^{16}$ Rebecca Scott writes that the Cuban planters in late nineteenth century Santa Clara, complained that they "could not find workers" unless they "extended advances" to emancipated slaves or Chinese coolies who had finished their indenture. She takes this to mean that "workers sometimes turned credit to their own advantage", because it "meant an effective increase in wages"-while being "risky business, since it could lead to [a] lasting debt" of peonage. ${ }^{17}$ However, these "activations" were more explosive than they are usually given credit for.

As Prabhu Mohapatra notes in relation to early nineteenth century colonial Bengal, the "customary practice of receiving advances before commencing work" was not so

\footnotetext{
${ }^{14}$ Brass and Bernstein, 'Introduction: Proletarianisation and Deproletarianisation on the Colonial Plantation', 17; Banaji, 'The Fictions of Free Labour: Contract, Coercion, and So-Called Unfree Labour', 87; Mohapatra, 'From Contract to Status?', 120.

${ }^{15}$ Arnold J. Bauer, 'Rural Workers in Spanish America: Problems of Peonage and Oppression', The Hispanic American Historical Review 59, 1 (1979): 478-86; McCreery, 'Debt Servitude in Rural Guatemala', 744; For Mexico see the overview by Alan Knight, 'Mexican Peonage: What Was It and Why Was It?', Journal of Latin American Studies 18, 1 (1986): 41-74; The revisionism begins quite early with Charles Gibson, The Aztecs under Spanish Rule: A History of the Indians of the Valley of Mexico, 1519-1810 (Stanford: Stanford University Press, 1964), 248-56. He argued that debt peonage was not that common and that it wasn't even a form of servitude. "The amount of the debt may be considered in some degree as a measure of the bargaining power of the worker." For the counterrevisionist see Brass, Towards a Comparative Political Economy of Unfree Labour, 202; Dore, Myths of Modernity, 28; For a contemporary and theorized discussion of advances Stephen Gudeman and Alberto Rivera, Conversations in Colombia: The Domestic Economy in Life and Text (Cambridge: Cambridge University Press, 1990), 90-7.

${ }^{16}$ Harry Walker, 'Demonic Trade: Debt, Materiality, and Agency in Amazonia', Journal of the Royal Anthropological Institute 18, 1 (2012): 140-59, 152.

${ }^{17}$ Scott, Slave Emancipation in Cuba, 235; see also Balboa Navarro, Los brazos necesarios.
} 
much an imperial "imposition" scheming "to tie down labourers", but rather an "absolutely necessary compromise in face of workers demands". The imperial wage advance in South Asia sprung from the indenture-like contracts made with sailors. As they were continuously enlarging their demands for them, the besieged British officials on site took it to be a principal "cause of their mutinous behaviour". ${ }^{18}$ Coolies from the Bay of Bengal, along with engagé labourers from Mozambique and Madagascar, had started making very similar demands on the plantations in Reunion and Mauritius - but only during the second round of contracts from the 1840s on. Their "weapon: competition among employers"-which resulted in an uncoordinated rise of ever higher advances and rates of desertion.

As in Fernando Pó of the 1940s, there was no overarching entity "between estate owners" and workers would move "from one estate to another," becoming "fugitives" and "deserters". ${ }^{19}$ Returnees to Madras and Bombay relayed "high wage rates or advances" and increasingly became sirdars or informal recruiters. Immigration levels to Mauritius peaked in the 1850 s and because of the escalation of this recruitment system planters adopted a "further shift in labour strategy", by "replacing the emphasis on immigration with the utilisation of existing labour through job contracting and the rise of small cane farming." In the 1860s "planters launched the first of several attempts to check the growing independence of time-expired Indians" or who "lived by cultivating rented or freehold plots, or hawking produce, by reviving sweeping vagrancy legislation." ${ }^{20}$ Planters took every chance they were given to denounce the "Indian propensity toward idleness, thievery, petty commerce, and

\footnotetext{
${ }^{18}$ Mohapatra, 'From Contract to Status?', 121; Nitin Sinha, 'Contract, Work, and Resistance: Boatmen in Early Colonial Eastern India, 1760s-1850s', International Review of Social History 59, S22 (2014): 11-43, 43; Balachandran, 'Making Coolies, (Un)making Workers'; Though some lascars could be more radical than the dashers: In "1800, British merchants accused lascars of wholesale arson: taking wage advances and then torching their ships so that they could abscond." Fischer, 'Working Across the Seas', 34. The "Commander in Chief at Madras, seriously suggested that all British soldiers on foreign service be tattooed to prevent them taking the bounty [and] deserting." Singha, "Settle, Mobilize, Verify', 20. Only over the course of the nineteenth century were advances and capitalist bondage recast in the moral languages of hybrid debt-ideologies of obligation, Prakash, Bonded Histories, 223-5.

${ }^{19}$ Stanziani, 'Beyond Colonialism', 74; also Carter, 'The Transition from Slave to Indentured Labour in Mauritius', 271; Allen, Slaves, Freedmen and Indentured Laborers, 59.

${ }^{20}$ Carter, 'Strategies of Labour Mobilisation in Colonial India', 238, 230; North-Coombes, 'From Slavery to Indenture' 109-13.
} 
financial irresponsibility", the last of which was projected in relation to their demands for advances. These "traits" were thought to lay behind the principal "reasons for [their] desertion and absenteeism". 21

In Assam, British planters started complaining in the 1870s "that time-expired coolies" had "become 'complete masters of the situation' due to competition for their labour-power, and went in search of the highest remuneration." A "bonus system had developed" where they were being paid up to 6 months dashes "to reengage". ${ }^{22}$ On these " "bargaining' capabilities" enabled through "garden sardars" operating "outside the legal-institutional framework", Nitin Varma cites a contemporary official in Sylhet who noticed " the increase in desertion of [the] tea garden coolie [who] have learnt to sell their labour power in the most profitable market, and are not mere adscripti glebae of the garden for which they were imported'."23 But it was especially those "labourers sent up by professional recruiters" the arkatis, who "had no particular bond to a specific garden and would, if they could, abscond from their contracts if offered better conditions in another garden." ${ }^{24}$ In Ceylon in the early twentieth century the planters complained not only about having "“suffered shortness of labour, but they have also suffered to a very considerable extent by the large advances now demanded by kanganies and coolies." The escalations and desertion arranged by touts of these "unrecorded advances" were paradoxically known in the Indian Ocean in this period by the term "crimping"- - because the dash was an inversion of the recruiter-crimp. ${ }^{25}$ While the dash was not an oppositional movement, it could overturn and invert the default flow of power relations and existing orders. Like plantation slavery but for

\footnotetext{
${ }^{21}$ Allen, Slaves, Freedmen and Indentured Laborers, 59.

${ }^{22}$ Behal and Mohapatra, 'Tea and Money', 147; Singha, 'Settle, Mobilize, Verify’, 163.

${ }^{23}$ Varma, 'Coolie Acts and the Acting Coolies', 53, 50.
}

${ }^{24}$ Sen, 'Commercial Recruiting and Informal Intermediation', 9. "The sardar was cheaper and his workers more likely to be 'suitable' since they were from a similar background. Sardari coolies were less prone to absconding, because of kin and community affiliation among new immigrants, the preponderance of married couples and a smaller number of solitary men and women, agreed inspecting officers in Assam."

${ }^{25}$ S. B. D. de Silva, The Political Economy of Underdevelopment (London: Routledge, 2012), 206, 329. 
different reasons, the system of indenture exploitation could only work through continuous renewal, with ever more batches of new recruits.

When the dash appears in African labour historiography it is sometimes considered as a credit-wage, even though it was often not technically an advance but an excess that surpassed the official wages of a contract. The efficacy and presence of the advance is always accounted for in the labour historiography. Outside of non-dialectical violence, the advance was the core component of the button that was carried all the way through in the thoroughly researched aspects of colonial wage-labour migration: recruitment ${ }^{26}$, stabilization ${ }^{27}$, and desertion. ${ }^{28}$ As can be shown in relation to the Southern Africa literature, the wage-advance is the switch that accounts for much of the early trajectories of labour mobilization in imperial labour markets, setting them off, holding them together and undermining their very constitution.

In most of South Africa around the 1910s advances had climbed to $30 £$ or almost a full years wages on contracts that were rarely signed on for more than six or nine months at a time - a dash outside but generated by the contract. ${ }^{29}$ In the early twentieth century gold mines of the Witwatersrand "wage advances bound the

\footnotetext{
${ }^{26}$ Beinart, 'Joyini Inkomo: Cattle Advances and the Origins of Migrancy from Pondoland'; Jeeves, 'Migrant Labour in the Industrial Transformation of South Africa', 116; Worger, South Africa's City of Diamonds, 288-90; Coquery-Vidrovitch, 'The Colonial Economy of the Former French, Belgian and Portuguese Zones, 1914-35'; Schuler, 'Kru Emigration to British and French Guiana, 1841-1857'.

${ }^{27}$ Arrighi, 'Labour Supplies', 223-4; Richardson, 'The Recruiting of Chinese Indentured Labour for the South African Gold-Mines', 102; Berman, Control and Crisis, ch.6; Berman and Londsdale, 'Crises of Accumulation, Coercion and the Colonial State', 76; Freund, 'Labor and Labor History in Africa', 201; Ferguson, 'Mobile Workers, Modernist Narratives'; Cooper, On the African Waterfront; Cooper, Decolonization and African Society, 63, 155-6; Cooper, 'Industrial Man Goes to Africa'.
}

${ }^{28}$ Van Onselen, Chibaro; 230-3; Harries; Work, Culture and Identity, 40-5; Atkins, The Moon Is Dead! Give Us Our Money!; Cooper, From Slaves to Squatters; Brown, 'The Dialectics of Colonial Labour Control'; 50-5; Breckenridge, 'Confounding the Documentary State'.

${ }^{29}$ Kubicek, 'Mining: Patterns of Dependence and Development', 78. In Southern Africa advances were bulky partly because until the 1910s they often came in the form of indivisible and valuable cattle. Beinart, 'Joyini Inkomo: Cattle Advances and the Origins of Migrancy from Pondoland'; Crush, 'Swazi Migrant Workers and the Witwatersrand Gold Mines', 33. Though where contracts were not very long or labour scarcity not too intense, such as in the cities, mining areas with a longer history, or well-worn labour migration routes, the advance was actually that: advances amounting to the first few months of wages at most that would be deducted on payday. Martin, 'Krumen "Down the Coast"', 410; Mark-Thiesen, 'The "Bargain” of Collaboration', 29-30. 
voluntary workers" because they "had to accept employment on one of the mines". ${ }^{30}$ Though it is clear that advances were so welcomed that many were accepting employment at two or more mines. In Southern Africa recruiters from the mines "“induced" potential wage workers to "enter into contracts [with] such large advances that the borrower "remained in debt"". At the same time, mobile workers were "accepting advances from several agents" with evidently "no intention of honouring their debts to any of them". ${ }^{31}$ Advances had become "so large that the incentive to desert before contract completion was considerable". ${ }^{32}$

Wage-advances, desertions and forgery were the integral folds of Van Onselen's "stop-go labour route" - a spiral which fully emerges in early twentieth century Southern Rhodesia, looping ever further south across the emergent lunar scape forged by mining capital, a quest for just remuneration that led many Zimbabweans to the Witwatersrand, the "best labour market of all within the regional economic system." Ever more bulky advances for new or deserting recruits and "inducements" to "recontract" incited much of this movement, a dialectics of presence and absence, of stabilization and abandonment. ${ }^{33}$ Van Onselen sketches the intricate itineraries of flights - mapped onto the incremental but negotiated wage-levels - as a political victory: "a relative coup which improved their lot." Attempts to track deserters down were often hopeless and haphazard.

In spite of decades of imperial experiments in papered contraptions - obligatory contracts, registration regimes, pass-laws and the like - most deserters, oscillating at around ten percent of the workforce, came out triumphant. The "most radical way" to outmanoeuvre the pass system as Van Onselen says was "simply to destroy them-a procedure widely resorted to by immigrant workers between 1904 and 1915." Destroying "what they knew to be a millstone around their neck" workers found their

\footnotetext{
${ }^{30}$ Jeeves, 'Migrant Labour in the Industrial Transformation of South Africa, 1920-1960', 116.

${ }^{31}$ James and Rajak, 'Credit Apartheid, Migrants, Mines and Money', 462; citing Schapera, Migrant Labour and Tribal Life, 109.

${ }^{32}$ Stichter, Migrant Laborers, 114.

${ }^{33}$ Van Onselen, Chibaro, 229; Worger, South Africa's City of Diamonds, 288-9.
} 
way, indubitably though the help a knowledge economy saturated by touts, to some new "pass office on the northern borders" where "new certificates" could be bought. ${ }^{34}$ This documentation regime was seen by the miner's lobbies as exactly that which gave "facilities" to "natives for desertion an re-engagement"-that is through "deserters leaving labour districts and re-entering them with fresh travelling passes, obtained from outside." 35 There "must have been some comfort in "working the system' in such a way that it left the exploiters exploited!". ${ }^{36}$

This is the double excess created by the dash-prolonged indebtedness and incited desertion-both the bind and the flight. In African labour history, the discrete connections and the wildly reconfigured moments of the actual handover-the passages of money before and after the bind-have not received the sustained attention and appreciation they deserve. ${ }^{37}$ On Fernando Pó, the dash, the cash that employers intended to advance as a debt-trap, left colonial capital in retreat, trying to fend off the escalations on the front line populated by reenganchos-'re-hooked' labourers signing onto a further contract. The reenganchos were accompanied by relatively small but disproportionately effective groups of ganchos and fugados'hook-people' and 'fugitives' or recruiter-touts and deserters. For the rest of the article

\footnotetext{
${ }^{34}$ Van Onselen, Chibaro, 230, 232. The 1910s saw the "state's drive for rigorous implementation of the Pass Laws" being churned out on a "significant scale". Breckenridge, 'Flesh Made Words', 88; MacDonald, 'Forging the Frontiers', 56. The "worker has almost complete control of the situation owing to the constant demand for his services. He is almost always able to find another employer anxious to engage him, so he can at any time leave his job and find another where conditions or type of work are more attractive." Orde-Browne, Labour Conditions in Northern Rhodesia, 21-3, cited in Cooper, Decolonization and African Society, 60. Even in late 1950s, desertion rates of almost $20 \%$ were reported by Rhodesian Native Labor Supply Commission for contract workers from Nyasaland. Clarke, Contract Workers and Underdevelopment in Rhodesia, 55-6.

${ }^{35}$ Witwatersrand Native Labour Association and Transvaal Chamber of Mines, 'Annual Report', April $1907,576$.

${ }^{36}$ Van Onselen, Chibaro, 230, 232.

${ }^{37}$ For a similar situation in anthropology see Maxim Bolt, 'The Sociality of the Wage: Money Rhythms, Wealth Circulation and the Problem with Cash on the Zimbabwean-South African Border', Journal of the Royal Anthropological Institute 20, 1 (2014): 113-130. In contrast, in precolonial West African history, debt bondage - and even "self-pawning" or people "selling themselves to get money (cowrie)"- - has received substantial attention. Law, 'Finance and Credit in Pre-Colonial Dahomey', 25; Law, 'On Pawning and Enslavement for Debt in the Pre-Colonial Slave Coast', 55.
} 
I follow the intersecting movements of these three figures along the archival sources they made an appearance in.

\subsection{Assembling an Economic Coup in 1952}

Until the early 1950s the "system in force" for "re-engaging workers on second contracts was quite irregular" to say the least. Spencer-Cooke, the British Vice Consul on the island, goes on to explain that it was "sufficient for an employer", without the bracero, to appear "in the Spanish Labour Office and state that the particular [bracero] wished to enter into another with the same employer". The Curador, Sebastian Llompart Aulet - a post he held between 1943 and 1962-would happily stamp these unsigned reengancho contracts that were being justified on the grounds of the outstanding debts generated through the "undesirable" and "illegal system of inducements"; as "all employers keep the personal copies of workers contracts this practice was all too easy". ${ }^{38}$ Llompart Aulet would eventually authorize the release of people after they had completed a few contracts; in this sense peonaje on Fernando Pó was akin to Igbo precolonial "debt-slavery", in that it promised an in-built but sometimes ill-defined expiry date. ${ }^{39}$

\footnotetext{
${ }^{38}$ British VC (Spencer-Cooke) to Commissioner of Labour, Lagos, 8 January 1950, 'Annual Report', TNA, CO 554/169/2; British VC (Lewis) to Cámara (Carbonell), 6 May 1946, AGA, C-81/08130, E-1. In 1950, the highest number of complaints related precisely to the issue of "cheques being delayed in the Spanish Labour Office", which would often leave a bracero bound "to recontract with same employer." British VC and LO (Spencer-Cooke) to Commissioner of Labour, Lagos, 30 September 1950, 'Labour Report for the period 1st of July to 30th September 1950', TNA, FO 371/89597.

${ }^{39}$ Uchendu, 'Slaves and Slavery in Iboland, Nigeria', 128; Ekechi, 'Pawnship in Igbo Society', 169, citing Talbot, The Peoples of Southern Nigeria, 698. makes the observation that "the status of a pawn [in] some Igbo communities" seems to be "analogous to that of an indentured servant or laborer" because "a limit of several years was imposed" after which a pawn was "to be released "whatever the amount of the debt"'. Precolonial forms of peonage have, particularly in West African history been artificially divorced from the worlds of imperial labour. Clarence-Smith, 'Cocoa Plantations and Coerced Labor in the Gulf of Guinea, 1870-1914'; Miers and Roberts, The End of Slavery in Africa; Falola and Lovejoy, Pawnship in Africa; Miers and Klein, eds., Slavery and Colonial Rule in Africa; Afigbo, The Abolition of the Slave Trade in Southeastern Nigeria; see Campbell and Stanziani, Bonded Labour and Debt in the Indian Ocean World.
} 

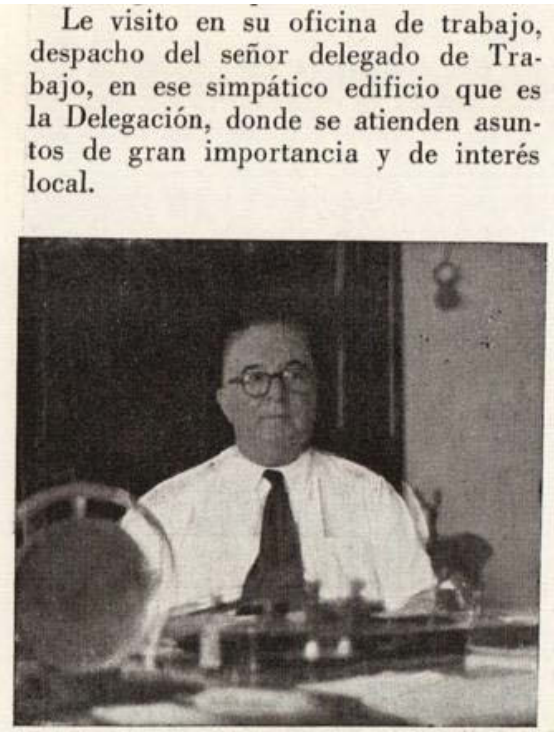

- Desde el dia

- ¿Cuántos añ actual cargo?

- Desde junio

-Señor Llomf ciar estos días la entre el bracero y el que lo termi ha llamado poder el hecho siguiente

$\mathrm{He}$ visto el des ble contingente de cedentes de Nigeri llegan generalmen una indumentaria extrañeza mayor e se refiere, ya qu ver reír a ningune que he comprobad barque.

Que se marchar nada tiene que env

Figure 10 The Curador, Sebastian Llompart Aulet, $\mathbf{1 9 5 5}^{40}$

Without a nullified contract "the labourer is unable to leave the island by orthodox means and the military control of the island is such that it is virtually impossible for him to leave by canoe". ${ }^{41}$ Indeed, a prominent trader from Lagos, Lola Martins, visiting Fernando Pó wondered why no one "absconded. Not under the Spanish Government. There is no way of escape in Fernando Po except to run into the sharks surrounding the island." 42 While there are indeed scattered traces of very risky exploit of a group of Nigerian braceros stealing "a canoe" who then tried to "row themselves back", desertion took the shape not of a permanent subtraction, an outwards escape or a flight onto the mountain tops, but as a cleft, spiralling inwards. ${ }^{43}$

\footnotetext{
40‘Hablando con el Delegado de Trabajo de la Guinea’, Industria En Guinea, September 1955.

${ }^{41}$ British LO (Nery), 17 June 1943, 'Nigerian Labour in Fernando Poo', TNA, CO 554/127/15.

${ }^{42}$ Lola Martins, 'African Tradition Abused in Fernando Poo', Express, Lagos, 22 February 1962.
}

${ }^{43}$ Policía, 'Registro de Incidencias 1953', entry of 10 November 1953, page 464, BNM. Already in the 1890 s the Consul reported that "British West African subjects had escaped by canoe from Fernando Po after being duped that they were going to work in Nigeria." Sundiata, From Slaving to Neoslavery, 132. This was relatively rare unlike for example in São Tomé, Clarence-Smith, 'The Hidden Costs of Labour on the Cocoa Plantations of São Tomé and Príncipe', 164-5. It does however resemble slave marronage in eighteenth century Mauritius, where, as Megan Vaughan says, "many maroons were urban runaways", working as hired subjects under negotiated terms of payment and with a variety of forged permits and identity papers in hand. In some "sense, a much more threatening prospect", she says. Vaughan, Creating the Creole Island, 172, 173. 
The "regalo", the dash, "through times past has served as an index of the variable scarcity - but always scarcity — of labour power on this island". ${ }^{44}$ In the three decades of colonial Francoist rule thousands of new settlers and a heavy dose of large corporate plantations rushed onto the island. The axiomatic "labour scarcity" was obviously intensified: in 1948 barely half of the island's self-declared "labour needs were being met". ${ }^{45}$ A resident amateur social scientist on the island notes around the year that the dash as well as the "labour scarcity" was reaching "a distressing and agonizing limit of which everyone is sadly very well aware": "demand has been so intense that the primas" the dash "given to the braceros the moment they sign the contract are swelling day by day. On the shoulders of this desperate necessity, the braceros have organized a picaresca laboral", a picaresque labour movement, that "has been very much to the benefit of the unscrupulous bracero and pretty damn onerous for our agriculture." ${ }^{46}$ Indeed the British Vice Consul to his own surprise was forced to speak of "the labour force [that] is, in many instances, exploiting the employers." ${ }^{47}$ Wages for a two-year contract were held down at a constant 700 to 1000 pesetas low, while the dash briefly reached 7000 pesetas (or £60), at which point the reenganchos were pocketing the entire surplus value being produced on the plantations - in particular cases twice as much. The "uncontainable rise" of the dash made "las fugas" flight, "become habitual. The braceros had been changing their names, and hired themselves to multiple employers, creating a malign indiscipline and an invitation to continuous fraud." 48

From the distant existing literature the movement of people from south-eastern Nigeria onto Fernando Po's plantations has been painted as a short wide pipe, with

\footnotetext{
${ }^{44}$ Cámara (de Sola Galvez) to Curaduría (Llompart Aulet), 17 October 1949, AGA, C-81/08130, E-3.

${ }^{45}$ DGMC, 15 January 1948, 'Informe sobre braceros', AGA, C-81/12373, E-392.

${ }^{46}$ Rafael Romero Moliner, 'Crónica de los territorios de Guinea', Cuadernos de Estudios Africanos 17 (1952): 90-2, 91 .

${ }^{47}$ British VC (Lewis), to British Embassy, Barcelona, 5 July 1946, 'Labour Conditions in Fernando Poo: Report on', TNA, FO 371/60392; or NAE, 17/1/278.

${ }^{48} \mathrm{GG}$ (Ruíz), 12 May 1952, 'Ordenanza prohibiendo las primas o regalos en la contratacion', Boletin Oficial; see also British VC and LO (Rylands) to Commissioner of Labour, Lagos, 8 January 1947, NAE, CALPROF 17/1/278.
} 
two phases. On one end, during the first phase, for about a decade after the beginning of the Spanish Civil War in 1936, is the canoe smuggling phase. The second phase (1943-1973) was an "indentured labour treaty" that supposedly represented the "efforts of the Nigerian Government [to] control and regulate on a sound humanitarian basis a traffic which existed on a slave basis". ${ }^{49}$ Under the 'treaty' prospective braceros signed their contracts in Calabar and received a small dash officially capped at five shillings, ostensibly so that labourers would not become "heavily indebted". 50 These "treaty-labourers" were attached to planters proportionately and after a two year contract or a maximum of 42 months they were repatriated and paid out on their return. The treaty had given the island a generous quota that had been "calculated to meet the demand", up to 10,000 labourers per year, however during the first decade of operation it never managed to sign up more that "about one third of this figure", and sometimes as little as a thousand per year. ${ }^{51}$ Until 1959 the services of direct or 'free' recruiters proved indispensable. They proved to be more effective when it came to numbers than any diplomatically negotiated labour treaties. Indeed, to subsist during the Francoist period many planters had to rely on touts as they were being excluded from 'treaty-labour' by the more powerful Spanish planters. This group of tout-dependant planters was made up of small Spanish planters, and small and large Portuguese, Fernandino, and German planters who made up over a third of employers.

From the archive there emerges a distinct and interstitial pipe (1940s-1950s), a kind of manifold funnel turning in on itself, made up of reenganchos contracts signed on the island and containing the dash component. The reenganchos were drawn from the ranks of clandestinely recruited first time labourers, deserters and new illegal immigrants. This bursting pipe generated a capillary like overgrowth with fugitive

\footnotetext{
${ }^{49}$ British VC (Lewis), to British Embassy, Barcelona, 5 July 1946, 'Labour Conditions in Fernando Poo', NAE, CALPROF 17/1/278. For an analysis of British 'indenture' as a kind of bureaucratic humanitarianism see Carter, Servants, Sirdars, and Settlers, 1-3; .

${ }^{50}$ Resident, Calabar to Editor, Nigerian Eastern Mail, Calabar, 4 August 1945, 'Nigerian Labour in Fernando Poo', NAE, CALPROF 17/1/278.

${ }^{51}$ British VC (Lewis) to GG (Bonelli), 8 June 1946, AGA, C-81/08130, E-1; Llompart Aulet, 'Nigerianos en las provincias ecuatoriales', 66.
} 
spores that rotted out the other two- "collapsing a filthy drainage pipe, causing a deluge to break loose, liberating a flow." The flow of the dash was not "an escape", a withdrawal, but was a flight "through" the world of the plantation, coupled to the multiplicity of "holes that eat away at it". 52 This is the pipe of the dash, of the dashed recruits, a texture where the tracing of individual routes in the actually existing archive is quickly frustrated by so many aliases, and hidden dash renegotiations; discontinuous spores, dispersed and overgrowing. Only the dash jammed a plantation island that was depending on conned and kidnapped Nigerians bound by long contracts during World War II and warded off what would become a tiny cousin of Apartheid's labour recruiting system in the late 1950s.

Dash workers were one of the broadly three figures that made up the ranks of braceros. This inherently unstable third pipe, made of a tout-worker assemblage, is one of broadly three figures that were seen to populate the ranks of plantation labour in post-civil war Fernando Pó. The first says, Bona Ekatem, were those "recruited by deceit and shoved into the plantation by force, who did not want this work and are therefore more prone to wreak palabras", palavers or disputes; the second are those "that are voluntary, the good ones, the bien conformados" which means those who have acquiesced, have resigned themselves or been knocked into shape-partly a provisional category and largely a figment hovering over the canvas of any planter's idyll. ${ }^{53}$ Braceros were not there to make a welfares career or seeking "stability" "security" or any long-term "guaranteed employment" 54 _ anyhow any actual trace of this paragon always hovering on the canvas of any planter's idyll, defected fairly quickly into the third class. This third class enacted and demanded a politics of radical proletarianization-elementarily to be paid the value of one's labour and to be able to

\footnotetext{
${ }^{52}$ Deleuze and Guattari, Anti-Oedipus, 341.

${ }^{53}$ J.E. Bona Ekatem, 'El trabajo en Fernando Poo', La Guinea Española, Santa Isabel, 3 September 1939.

${ }^{54}$ Alfredo Jones Niger, December 1938, 'Memoria sobre el problema de la mano de obra en la isla Fernando Poo', AGA, C-81/08128, E-1. Less than 1\% stayed on, on the plantation hierarchy. By the late 1950s many capatazes were Nigerians who would also "inflicted corporal punishment when need be." 'Fernando Poo', Eastern Nigeria Guardian, Port Harcourt, 14 August 1957. For a critique of the paternalism of debt bondage, see Brass, 'Class Struggle and the Deproletarianisation of Agricultural Labour', and its dissolution because of workers' independence, see Surinder S. Jodhka, 'Agrarian Changes, Unfreedom and Attached Labour', Economic and Political Weekly 30, 31 (1995): 2011-13.
} 
leave employers unencumbered by borders or contracts - as well as a politics of radical deproletarianization. Indeed the principal aim of braceros was to "exit the colonial contract" world completely "as soon as the internal circumstances that forced him to contract cease". ${ }^{55}$ After listing the first two classes, the Nigerian journalist Bona Ekatem outlines this "third class" whom he calls "the vagos", the vagrants. In "one word the maleteros", the "suitcasers" "who have until now have dedicated themselves in Calabar to trying to carry the suitcases of passing passengers in order to live off the tips and in this way to spend life in "dolce far niente" in "delicious idleness'. "These types have gone to Fernando Poo following the scent of the regalo [advance] which the recruiters then swindled them out of." 56

British colonial authorities saw this and thought that "for reasons quite unknown illegal immigration offers certain attractions to the immigrant", but the Secretary for the Eastern Provinces in Nigeria surmised that the "principal reason, not the least among them", was of "an economic nature". ${ }^{57}$ Spencer-Cooke, the Vice Consul, thought it "strange that so many workers are persuaded to come here [but] the fascination of being promised such a large sum of money as $£ 15$ to $£ 30$ is a temptation hard to resist [for someone] who has probably rarely handled a greater amount than $1 /$ " - that is 1 shilling, twenty shillings to a pound. The "hopes" of these new smuggled recruits were "never realised of course", a first time bracero was "lucky to get $£ 3$ " at the end of their contract, while "the remainder" invariably went "into the pockets of the illegal recruiters". ${ }^{58}$ Okon Archibong, a political activist in Calabar sums up the mood amongst these braceros, once they realized what type of exchange had just taken place: "Every thinking man can prove beyond doubt how

\footnotetext{
${ }^{55}$ Romero Moliner, ‘Apuntes sobre la estructura social de Fernando Poo’, 46.

${ }^{56}$ J.E. Bona Ekatem, 'El trabajo en Fernando Poo', La Guinea Española, Santa Isabel, 3 September 1939. He was apparently a Nigerian journalist of the West African Pilot, although the name was more likely a pseudonym of a Spanish agent publishing under a propagandist alter-ego.

${ }^{57}$ Secretary, Eastern Provinces, Enugu to the Resident, Calabar Province, 9 June 1951, NAE, RIVPROF $2 / 1 / 53$.

${ }^{58}$ British VC (Spencer-Cooke) to Commissioner of Labour, Lagos, 8 January 1950, 'Annual Report: Fernando Poo 1950', TNA, CO 554/169/2. The annual tax obligation in Nigeria hovered around the 5/ mark and an Igbo bride-wealth around the 15-25£ mark.
} 
these victims felt when they were landed at Fernando Po" their "wages" meaning their potential dashes "having been paid to the middle-men". 59 "They always sell man two years called sign", as a letter from a group of braceros explains. ${ }^{60}$ Another petition by a group of braceros tells how after a week into their first contract "we saw one man who shows us road back to the town" where they complained to the Curador, who "reply us that the parties who brought us here have claimed £6-0-0 per each head [and] so we must go and work for the farm for good 2 years". When they "strictly refused" to be interned in the plantation the Curador "held us in prison until we are agreed to go back to the farm, as up to date we are in prison with heavy punishment". ${ }^{61}$ The Curador, an agent of neo-slavery, pulled the carpet from under the feet of new braceros; but this only happened once.

This Atlantic crease was upended by reenganchos who transformed the dash from being a component of a recruiter's capitation fee, into a moving medium for assessing and asserting their own bargaining power. The "odd thing", says a slightly surprised British Consul General in 1953, "is that although men who are sent to Fernando Po by illegal means, such as trickery or kidnapping, tend to be resentful at first, many of them give in and agree to the conditions". The Consul General's subdued way of phrasing these realities concealed both preposterous overstatements - "give in and agree"- as well as understatements: "it is also odd that although in some ways the Spaniards are strict, if not harsh, in their relations with their African workers, many Nigerians stay on there for years". ${ }^{62}$ In the early 1940s, W. Evans, the British Labour Officer on site gathered from some of the migrant workers who served as his paid informants, that those who were "completing their contract" were not going back home just yet with nothing to show from many years of hard work abroad, but had instead started to "put a high premium on their future services". The "recruit, soon learns that without his services the employer will be ruined and at the expiration of his

\footnotetext{
${ }^{59}$ O. Archibong to Resident, Calabar, 23 January 1939, NAE, CALPROF 5/1/194.

${ }^{60}$ Petition signed 'Your Prodigal Sons' to Resident, Calabar, 24 March 1936, NAE, CALPROF 5/1/194.

${ }^{61}$ Petition signed by A.Afiatai, addressed to 'District Officer, Nigeria', 28 October 1932, NAE
} CALPROF 5/1/192.

${ }^{62}$ British Consul General, Brazzaville, 12 June 1953, 'Tour', TNA, FO 371/102621. 
first contract he may himself employ a tout to offer his services for re-engagement to the highest bidder".

Evans describes the reenganchos as being "fully alive to the possibilities", and "out to make capital of the situation". During this reshuffling for the second round of contracts he also witnessed how "intermediaries who have scented the elements of a racket are springing up wholesale. These 'agents' - themselves Nigerians - haunt Santa Isabel and the neighbouring farms in search of likely recruits and, of course, take their cut out of the bonus offered". ${ }^{63}$ This was a novel shift. A German scientist stuck in Fernando Pó at the outbreak of World War II, observed that "usually the Nigerian Gastarbeiter returned home" after a first contract "with three to five pounds in savings". ${ }^{64}$ In the late 1930 s it could still be said that "the labour question" was "likely to become serious" since those "who finish their contracts show little desire to sign a new one." ${ }^{65}$ The labour question took a serious turn not because of the refusal to sign second contracts and the absence of new arrivals but because of those already there redeployed themselves.

Up until the early 1930s there was an officially registered regalo of exactly 300 pesetas "for re-engagement [which] changes hands in front of the Spanish labour officer" - a small sum, about the price of 15 bottles of olive oil or ten dozen eggs or twenty five meters of cloth in the markets of the capital Santa Isabel, that almost exceeded one year's worth of official bracero wages. In the 1940s, however "outside the door of the Labour Office" around the negotiations of decentralized toutemissaries "an unofficial and much more substantial dash" was being exchanged. ${ }^{66}$

\footnotetext{
${ }^{63}$ British LO (Evans) to British Consul General, 26 May 1944, TNA, FO 371/39661; British LO (Evans), 30 June 1945, 'Native Labour, Monthly Report, No. 16', TNA, FO 371/49598; British VC (Lewis) to Commissioner of Labour, Lagos, 11 June 1946, 'Illegal Recruitment in Nigeria by "ganchos" appointed by Spanish Employers', NAE, CALPROF 17/1/278.

${ }^{64}$ Wolff, 'Ein Beitrag zur Wirtschaft von Fernando Poo', 98.

${ }^{65}$ Governor of Nigeria (Bourdillon), Lagos to Sec. of State for the Colonies (Crimsby-Gore), London, 29 October 1937, TNA, FO 371/22669.

${ }^{66}$ British VC (Lewis) to Commissioner of Labour, Lagos, 11 June 1946, 'Illegal Recruitment in Nigeria by "ganchos" appointed by Spanish Employers', NAE, CALPROF 17/1/278; British VC (Lewis) to Commissioner of Labour, Lagos, 20 June 1946, 'Ref. No. L.23/6 Spanish Organisation for the reception at Santa Isabel and repatriation of Nigerian Labour', NAE, CALPROF 17/1/279.
} 
This "unofficial regalo" laments a planter "has been consecrated by the reality of the bargaining power of labour". ${ }^{67}$ In 1949 the Curador refused to inscribe the real amounts of this "free playing system of primas" in his registry or onto contracts. The "300 peseta limit", he says, one imagines in a desperately raised voice, was the "only way to brake the regalos of the underground market of labour which have been elevated to absurd levels". For the Curador-who was annually being rewarded some 45,000 pesetas for performing his duties - the "regime of regalos, free playing as to its quantity is a danger", not only because it "defrauds the fiscal regime", since it was tax free, but because he saw it as driven by the "venality of the uneducated native and the maliciousness of men in general, when they are moved by economic reasons alone".

Sebastian Llompart's immediate reasons lay in a more prosaic and typical anxiety: the workload of paper-shufflers. "Today", he says, "the handing over of the 300 peseta regalo is always the same, it is done automatically and everyone knows the quantity given and received." He then engages in some arithmetic acrobatics for rhetorical sway: "it would take at least 4 minutes to hand over 1500-2000 pesetas", counting the labour of the "cashier, then the necessary European supervisor has to count the bills, the bracero who is contracting would have to count the bills as well." The "average number of contracts presided over" by the Curaduria per day were "approximately fifty, and this means" that the process of counting and inscribing the dash in the books "would take over three and half hours more per day"! His "office" it seemed was already "way too knee-deep in work" to play cashier. ${ }^{68}$ During the post-war decade it was reenganchos, "as many as 25,000 non-Treaty labourers" in 1952, who were making the majority of contracts — some fifty a day. ${ }^{69}$

The press-storm forming over Fernando Pó was reaching one of its many apogees in the late 1940s-with vivid and haunting titles of incarceration and damnation that

\footnotetext{
${ }^{67}$ Cámara (de Sola) to Curaduría (Llompart), 17 October 1949, AGA, C- 81/08130, E-3.

${ }^{68}$ Curaduría (Llompart) to GG (Bonelli), 8 November 1949, AGA, C- 81/08130, E-3.

${ }^{69}$ Nigerian Secretariat, Lagos, [undated, 1953] 'Memorandum on the Labour Connection Between Nigeria and the Spanish Territories in the Gulf of Guinea,' RHL, 600.18 s. 21/XI (10).
} 
drew on a Euro-African imaginary of satanic mills and cruel dungeons: a "Biblical Hell", ${ }^{70}$ a "Hell on Earth", ${ }^{71}$ an "Island of no return", ${ }^{72}$ the "Brutal Island", ${ }^{73}$ with "Wickid Laws and Wickid Rulers", where a warp or short-circuit had spawned "paid slavery". ${ }^{74}$ Journalistic exposés contained interviews with returning labourers who told "newsmen in Calabar that they had suffered "the most inhuman, hellish and brutal treatment' they ever had heard of in their lives"-principally at the hands of the colonial police. While licensed recruiters were operating in south-eastern Nigeria from 1943 on, they had difficulties persuading a substantial new generation of recruits - at least until the very late 1950s. For the popular writer Peter Enahoro, the prickly question - a modern fright - was what seemed to be an irrational consent to 'voluntary servitude'. "In Fernando Po, I was ashamed. I WAS ASHAMED that in spite of the treatment they got, they still came in numbers". ${ }^{75}$ Understanding the precise number and composition of the workforce goes a long way in assuaging Enahoro's sense for the incomprehensible goings-on.

${ }^{70}$ Candidus, 'Recruitment of Labour to Fernando Po,' The Nigerian Eastern Mail, Port Harcourt, 5 April 1947.

${ }^{71}$ V.S, 'Hell on Earth', New Times, Lagos, May 1962.

${ }^{72}$ Isaac Pepple, 'Free Ticket to Hell,' Drum, Lagos, April 1957.

${ }^{73}$ Peter Pan, 'The Brutal Island', Sunday Times, Lagos, 18 February 1962.

${ }^{74}$ Peter Pan, 'Wickid Laws and Wickid Rulers', Sunday Times, Lagos, 25 February 1962; A famous columnist in Calabar, always signing off with the name Candidus, summarizes this later history of Atlantic capitalism, where the justification of colonial violence of indentured labor derives directly from racism, without skipping a sentence or adding punctuation, the two points are related: "We are told that these recruits are officially designated as lazy Nigerians and it is slur on ibibo and ibo tribes to allow them to be sold onto slavery in foreign lands." Candidus, 'Recruitment of Labour to Fernando Po,' The Nigerian Eastern Mail, Port Harcourt, 5 April 1947; On the use aliases in relation to Nigerian political and print cultures see Stephanie Newell, The Power to Name: A History of Anonymity in Colonial West Africa (Athens: Ohio University Press, 2013).

75 'Writer vehemently condemns idea of Labour Recruiting to Fascist Territory', Eastern Nigeria Guardian, Port Harcourt, 1 March 1945; Isaac Pepple, 'Free Ticket to Hell', Drum, Lagos, April 1957; 'We were Tortured, Starved', Nigerian Outlook, Enugu, 27 January 1961; V.S, 'Hell on Earth', New Times, Lagos, May 1962; Peter Pan, 'The Brutal Island', Sunday Times, Lagos, 18 February 1962. Enahoro's wrote under the moniker "Peter Pan". Enahoro's vicarious sense of disgrace was also projected onto colonialists: "I WAS ASHAMED for the Spaniards -good Catholics all of them- who treated their fellow men like beasts of burden". 


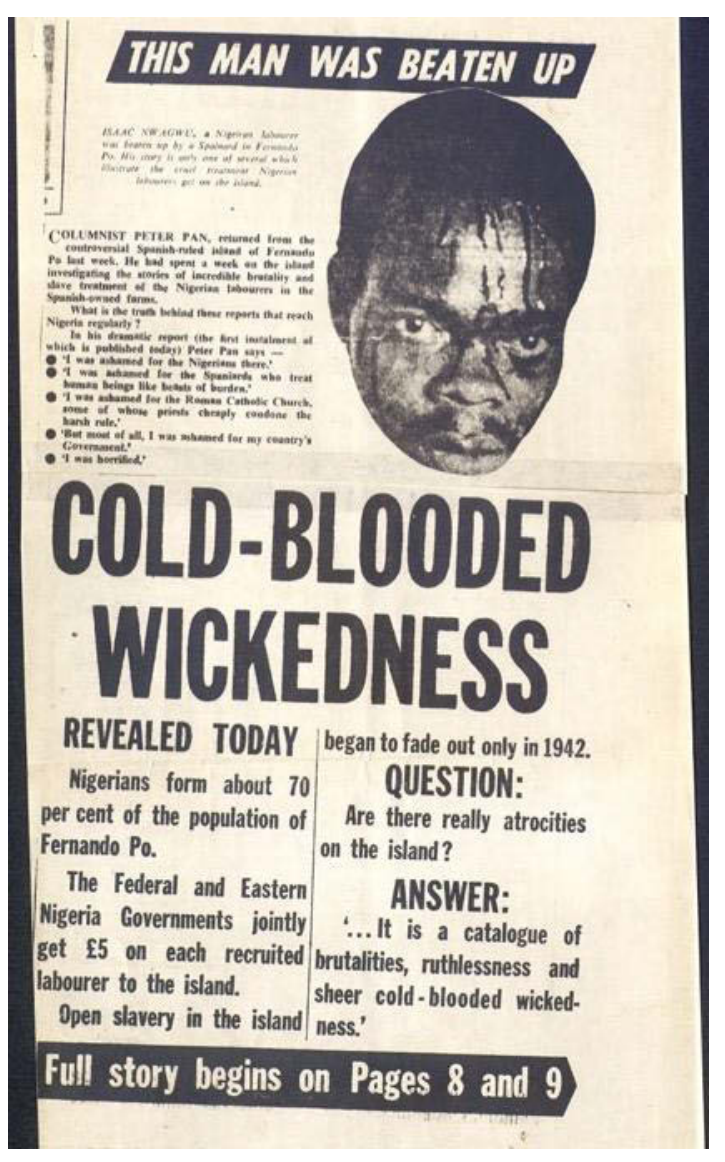

Figure 11 Peter Pan's 'Brutal Island' in Sunday Times ${ }^{76}$

In the hundreds of press articles covering or commenting on the scandals coming out of "hell's island", the dash was never mentioned directly, though if it had been, it might have been described as a deal with the devil. After World War II, the canoegoing clandestine recruiters started encountering a revamped Nigerian navy and the number of smuggled labour dropped sharply. So it was Nigerian reenganchos who were signing the majority of contracts. They were the first generation to radically escalate the dash. They renegotiated its twenty-fold increase in a little over ten years - doubling the effective wages of braceros every time they were released from an expired or sabotaged contract. Thrown and kept in the bottom rung of the colonial economy because of an initial ruse, a dire need, or dreams of excess, they figured out a way to stay on the plantations only as long as necessary. This they did in collaboration with touts.

\footnotetext{
${ }^{76}$ Peter Pan, 'The Brutal Island', Sunday Times, Lagos, 18 February 1962.
} 


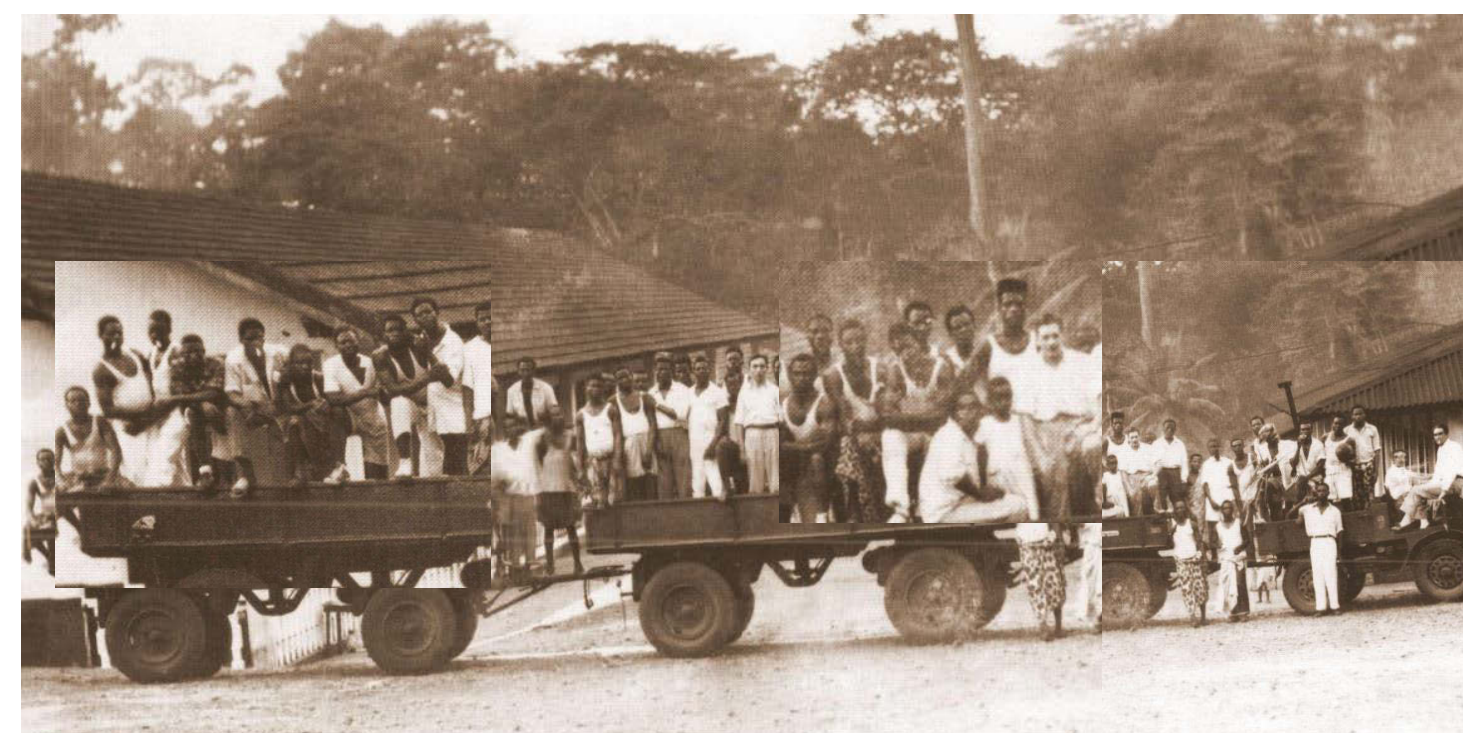

Figure 12 Nigerian braceros in plantation 'Casa Mallo', 1950s ${ }^{77}$

\subsection{Dash Renegotiations: Gancho-Touts}

For the "prospect of returning to Nigeria with $£ 24$ in their pockets"- that is with the dash of a reengancho in their pockets - the bracero was "prepared to risk work in Fernando Po [even] if he is unlucky to find a bad master." ${ }^{, 78}$ Contracts on the island were irrevocable and fixed in length. The dash marked the entry into them, a threshold with a very ambivalent sign: "it [was] generally recognized by the labourer that the higher the 'dash' the worse the conditions are on the farm, but quite often their cupidity gets the better of them". ${ }^{79}$ Once on the island however, the reenganchos were "very discerning when signing second contracts: they naturally seek the best pay and amenities", and this was the only "stimulus" for "employers to make their farms more attractive." ${ }^{80}$ Reenganchos tended to stay clear of planters "who had a reputation

\footnotetext{
${ }^{77}$ Adapted from José Manuel Brunet et al., Guinea en Patués: De los bueyes del Valle de Benasque al cacao de la isla de Fernando Poo (Huesca: Diputación de Huesca, 2008), 121, see also 116-9.

${ }^{78}$ British LO, Calabar to Government, Lagos, 23 March 1945, AGA, C-81/08130, E-1; British LO, Calabar to Government, Lagos, 15 November 1945, AGA, C-81/08130, E-1.

${ }^{79}$ British VC and LO (Bradley) to Commissioner of Labour, Lagos, 31 March 1950, 'Labour Report No.1/1950', TNA CO 554/169/1.

${ }^{80}$ British VC and LO (Bradley) to Commissioner of Labour, Lagos, 20 March 1956, 'Annual Report covering the period 1st of April, 1955 - 31st March, 1956', TNA, CO 554/1346.
} 
of ill-treating the labourers". Planters with a reputation "sufficient to frighten" reengancho "labourers away" were slowly forced to do away with the ranks of abusive Portuguese, Spanish and British West African overseers - in that numerical order-if they wanted anyone to "recontract". When they did, they found that they were "now able to find labourers from other farms, who were prepared to serve their second contract with" them. ${ }^{81} \mathrm{Up}$ until the 1940s the "farms that treat their workers like in the rest of the civilized world" were "very hard to find" and those who did "recontract, the reenganchos, prove to be badge of honour and reputation for the planters, and benefit the bracero too because it represents an increase in salary and a guarantee of good working conditions." $" 82$

The dash for reenganchos far exceeded the 'trade-dash' commanded by clandestine recruiters because planters were paying out extra for experienced hands - the skilled wielding of long-armed sickles making exact incisions on the dangling cocoa pods without which any subsequent blossoming was irreversibly lost; the keeping constant of furnace temperatures in the tin roofed chimney sprouting cacao drying houses; and much more. The British Vice Consul thought he knew his economics: the "undesirable" and "illegal" "system of inducements" "would disappear entirely if the numbers" of new recruits under the Treaty could be "increased." ${ }^{83} \mathrm{He}$ was partly right, but he excluded from his estimation the value of experienced labour.

\footnotetext{
${ }^{81}$ British VC and LO (Bradley) to Commissioner of Labour, Lagos, 2 January 1952, 'Report No.4/1951', TNA, FO 371/96714. At the work place braceros had to deal with people like Domingo Alvarez Cruz, a Portuguese plantation manager of whom a small vignette has been left in a labour inspector's report who was on his very first tour on the east side of the island, only reachable by surfboat. Even this inspector, a military man - who had been a roused fellow traveller, as all Francoist administrators on Fernando Pó were, in the systematic deprivation, war-crimes, attrition and firing squads during the Spanish Civil War-was struck by the figure and presence of Don Alvarez. With an emphatic distance and a penchant for character study he depicts Don Alvarez as "a tall and slender man, sinewy, with a cold and penetrating stare, of a forceful and uncompromising character" with an "opinion" he repeatedly expressed: "the bracero is indolent and one needs to make them work to extract from them the maximum yield." Unsurprising then that at this plantation there were "several fugados and almost no recontratados, no one prolongs their contracts for normal motives." AT Santa Isabel to GG (Fontán), 17 December 1941, AGA, C-81/08128, E-13.

${ }^{82}$ Carles, Misioneros, negreros y esclavos, 38.

${ }^{83}$ British VC (Lewis) to Commissioner of Labour, Lagos, 11 June 1946, 'Illegal Recruitment in Nigeria by "ganchos" appointed by Spanish Employers', NAE, CALPROF 17/1/278; British VC (Lewis) to Cámara (Carbonell), 6 May 1946, AGA, C-81/08130, E-1.
} 


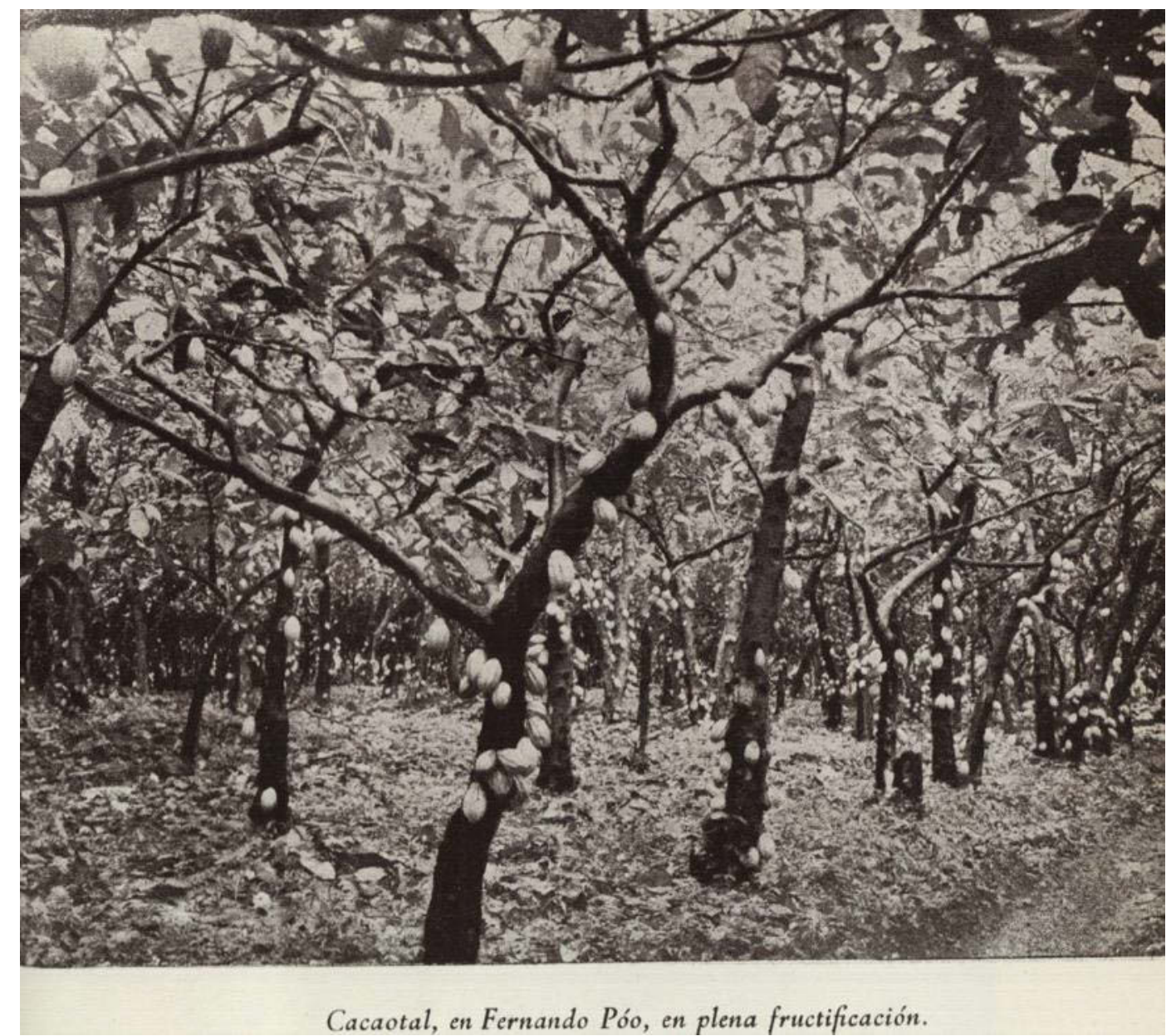

Figure 13 Cacao trees with ripe cocoa pods, $1940 \mathrm{~s}^{84}$

The numbers of treaty labourers did not anyhow increase, in fact he writes in 1950, "since 1946 the labour force has fallen steadily in numbers but production figures have not"-compensated by the experienced "workmen" often being "kept under pressure all day from $6.30 \mathrm{am}$ to $5.30 \mathrm{pm}$ without any established rest period" during the harvest season. ${ }^{85}$ The "high productivity of these most diligent reenganchos quickly generated a group of agent entrepreneurs, the ganchos" or recruiter-touts. ${ }^{86}$ The 'tout, called 'gancho' which means 'hook' in Spanish receives 400 pesetas for

\footnotetext{
${ }^{84}$ Original caption: "Cacaotal, en Fernando Póo, en plena fructificación”, in Baguena, Manuales del Africa Española, 50.

${ }^{85}$ British VC and LO (Spencer-Cooke) to Consul-General, Barcelona, 8 November 1950, 'Report on the existing Labour conditions in the Spanish Territories of the Gulf of Guinea', TNA, FO 371/89597.

${ }^{86}$ Velarde Fuentes, 'Problemas de empleo', 165.
} 
every recruit whom he claims to the employer." ${ }^{87}$ But like some recruiters before them who "took commissions" on "the same braceros from at least three employers" the "result being a very profitable business, and a very illegal one," the worker-tout assemblage that took over the island in the 1940s could ally, recombine all the same elements and coil up the system to the extreme. ${ }^{88}$

Ganchos were a discontinuous and unrelated groups, who often started off very modestly and, again, armed themselves only with the capacity to handle, embellish and inflate language and money. They were drawn from the ranks of lowly and landless Spanish and Portuguese pichinglis speaking settlers, from the community of urban Creoles or Fernandinos and West African self-employed immigrants, from the existing entourage of Calabar-based recruiter kingpins, or they were former braceros themselves with a few contracts under their belt - they were "neither planters nor merchants, they [were] usually not even actual proxies or company agents". ${ }^{89}$ The dash was fanned by refractory mediators who never operated with the full blessing of the planters and the administration. A planter pleaded: "make the intermediaries disappear, for, as a rule, they are persona extraña”-external, but also strangers, strange, startling - "to real colonial interests, their only aim is the acquisition of maximum wealth with minimum effort, and for sure they do not create the permanent wealth" that agro-capitalist planters, like himself, liked to think of themselves as generating. ${ }^{90}$ They generated wealth on the move, at a distance from both capital and labour. Labour touts could confound and reroute the imperial economics of labour scarcity-they spotted gaps and pushed it, and its paperwork, to extremes.

\footnotetext{
${ }^{87}$ British VC (Lewis) to Commissioner of Labour, Lagos, 11 June 1946, 'Illegal Recruitment in Nigeria by “ganchos" appointed by Spanish Employers', NAE, CALPROF 17/1/278.

${ }^{88}$ Curaduría (Guixeres) to GG (Guerra), 29 June 1936, AGA, C-81/08153, E-1.

${ }^{89}$ Joaquin Jose de Sousa to GG (Manresa), 17 September 1931; Curaduría to GG (Manresa), 26 of September 1931; Primitvo Alvarez to Chrits Nordenholz, 14 March 1931, AGA, C-81/08126, L-1, E34.

${ }^{90}$ Cámara (Estrada), 15 May 1930, 'Nota sobre el problema de brazos en Fernando Poo', AGA, C$81 / 06415$, E-13.
} 
The Spanish settler Fernando García Gimeno worked as a labour contractor for a group of Portuguese planters and fondly recalls in his memoirs how he enrolled a small but peaceful army of Nigerian ganchos. These "would bring potential recruits to the best farms we had" - often not the ones "they were actually going to be destined to"- and would "win them over by inviting them to lunches and things. We even paid for a session with a woman of the night." This Dionysian pampering, an inversion of the plantation's unchanging and imported food rations of rice and stockfish that came with the contract, served to "screw the competition" out of labourers, as García says. ${ }^{91}$ Everyone was "well aware of the existence of 'ganchos' whose mission it [was] to capture those braceros who presently find themselves in Santa Isabel because they just completed a contract"- but no one could actually stop them.

The touts gained a status, not from a division of labour, but from inserting themselves into the modalities of commissions. With almost theatrical pathos, planters started complaining that the ganchos were "twisting the will" of the braceros who were abandoning them after their first contract. ${ }^{92}$ This liminal phase corresponded to the validity of a 14 day papel de libertad, a "freedom paper" handed over to braceros when finishing a contract so they could buy a ticket and wait for the bimonthly steamer to take them to Nigeria, or so they "may look for work without risk of being taken by the police". ${ }^{93}$ A contract was always laid out at the end of this strangely selfimploding grid of reallocation and inducements, because a series of vagrancy ordinances had made unemployment illegal on the island.

\footnotetext{
${ }^{91}$ Garcia, Fernando el africano 45-48. García was a Spaniard of a modest family who arrived after the Civil War when he was a boy. His parents started working at his aunt's restaurant in Santa Isabel. It is strange that being informed or allowed to select the place of work did not seem to matter to the Spanish settlers, bracketing it under the "daily conflicts were of a minor sort", such as "being destined to plantations other than those promised. This was because the majority of firms had different 'patios', one in Basakato the other in Fistown. The workers was promised work in the farm closest to the city, but in the end he was sent to the one further away."

${ }^{92}$ Cámara Bata to GG (Bonelli), 3 August 1946, AGA, C-81/08129, E-1. The shameless Cámara even tried to propose a tax on the reenganchos who hire themselves elsewhere, about "half the going rate of a regalo to be paid to the Camara" to disarticulate the relation between a "new employer and his 'gancho"'.

${ }^{93}$ British VC (Robertson) to British Consul General, 30 December 1944, TNA, FO 371/49598 or NAE, CALPROF 17/1/277.
} 
The dash could only emerge from a reign of long contracts, but its flourishing was purely the outcome of touts and workers combining. The African history literature that promised to offer "a rare glimpse into the actual mechanics of the labour market" has shown that the internal logistics of the dash were largely arranged by touts. But these touts have nevertheless been explicitly disparaged as "lawless" and "depraved". ${ }^{94}$ Dispersed sets of touts were the ones channelling and bidding up the informal dash, relaying but also cracking open the edifice of imperial bondage on the final African shores of the Spanish Empire. Out of it came a realization and a practice that effected a radical coup against an arrangement that officially only promised poverty wages and a high risk of being killed - there were one to two deaths per day-by what can euphemistically be called the guardians of public order and workrelated injuries. ${ }^{95}$ By "hook or by crook", as is said in Nigeria, they pocketed commissions, proposed unnecessary fees and often conducted scams-the underground has its contradictions too.

\footnotetext{
${ }^{94}$ Murray, "Blackbirding" at "Crooks" Corner', 376. See especially Jeeves, Migrant Labour in South Africa's Mining Economy, 3-34, 239-64; and MacDonald, 'Colonial Trespassers', 242-90.

95"During this quartile for example 26 Treaty workers and 41 non-Treaty workers [...] have died [...]" Counting only the Treaty workers the Vice Consul says: "Up to March, 1952, 508 deaths had been reported which represents $3.6 \%$ of a labour force of 14,174, 13,666 of whom were repatriated during the period May, 1943 to March, 1952. This death rate was "11 times greater than in [the rubber plantations of] Calabar". The Spanish "medical authorities continue to be reluctant to certify workers who become physically incapable of completing their contract and this is certainty a contributory factor to the high death rate amidst Nigerian workers". British VC and LO (Bradley), 1 October 1952, 'Labour Report, July 1st to 30 September 1952', TNA, FO 371/96714. Eyo Udo registered a complaint with the Vice Consul in 1941. He simply wanted to be able to get to the Hospital, it "being dangerous to just wait and die as happened with the other braceros". Explaining his situation, he remembers his recently deceased brother "Isaiah" who "had a wound on his foot", and instead of "receiving treatment at the Hospital" as he had requested he was taken "to the warehouse" of the plantation of Antonio Perez Lopez, and whipped several "times with a rubber tubing" and "locked inside during the night." His foot injury festered and the overseer sent Isaiah to the hospital four days later as a corpse. The pick-up truck that brought him there carried away "the cadaver of another bracero, who had also died due to mistreatment at work in the same farm." Udo explained to the Vice Consul that the Spanish authorities "take it as joking we don't know that it fact they say." The Gobernador, Fontán, replied to the Vice Consul regarding this case, clearly deflecting, by insisting "that the veracity of such declarations are untested". Fontán then forwarded him a copy of the coroner's report which blatantly lying, declared: "natural death caused by organ failure." Eyo Udo, 8 September 1941, AGA, C-81/08128, E-12; GG (Fontán) to British VC (Michie), 27 November 1941, AGA, C-81/08128, E-12. The warehouse-a granary-like provisional prison pioneered by the ancients in Mesopotamia-was the favoured place for overseer to lock up and abuse workers.
} 


\subsection{Dash Life: Smugglers, Prostitutes and Planters}

The "point of view of the bracero" was to "never want to remain a bracero but for as short a period of their life as possible, or at least that is their intention." 96 The Nigerian reengancho found himself in "Fernando Po with the sole object of making his fortune in his small way"-figuring out an overriding purpose: to "make money as quickly as possible". ${ }^{97}$ A survey of 500 new recruits were asked at the labour department in Calabar as to the "purpose for which the labourers were seeking to earn money under contract". The answers were: "To engage in petty trading", 36\%; "To pay dowry for a wife", 23\%; "To purchase a bicycle", 10\%; "To assist parents or other relations"; 9\%. The questionnaire is a nonsensical format since all four reasons contain and presuppose each other, and much else besides. ${ }^{98} \mathrm{~A}$ former bracero-who in the 1950s turned himself into a prosperous smuggler of canes and batonsremembers the Fernando Pó of the booming post-war heyday as "a place of many profits", "money everywhere, if something was a luxury in Nigeria, here it was in abundance". ${ }^{99}$ The thousands of Spanish settlers — when not bossing and attacking people on the plantations or manning most administrative positions-were largely busy running the "many, many, many factorias that plague Santa Isabel. The European emigrant is quite a fan of commerce. Santa Isabel is full of their factories,

\footnotetext{
${ }^{96}$ Romero Moliner, ‘Apuntes sobre la estructura social de Fernando Poo’, 42.
}

${ }^{97}$ LO Calabar to Government, Lagos, 23 March 1945, AGA, C-81/08130, E-1; Osuntokun, 'Relations between Nigeria and Fernando Po', 10. Among "Nigerians" in Cameroon "on the whole do not intend to stay longer than is necessary to obtain capital with which to return to Nigeria." Ardener and Ardener, Kingdom on Mount Cameroon, 198.

\footnotetext{
${ }^{98}$ Nigeria, Annual Report on the Department of Labour and Resettlement of Ex-Servicemen, 1949/50, 24. Of 400 interviewees, it is said by the report writer that "other purposes named by small numbers of workers were - to improve knowledge, to get experience by travel, to buy farm land, to build a house, and to pay school fees. The desire to possess a bicycle is in the Eastern Provinces from which the recruits come, inspired by more than the mere pleasure of riding one. Bicycle carriers are a special feature of both Ibo and Ibibio country and serve the needs of the population in place of carts and taxis. A bicycle owner thus possesses a means of livelyhood." All the four hundred "were asked to state their previous occupation, with the following results": Occupation-Number, Farmer-132, Petty trader-60, Artisan-44, Labourer-32, Fisherman-28, Domestic servant-24, Carrier cyclist-24, Palm tree cutter-24, Student-20, Clerk-8, Teacher-4.
}

${ }^{99}$ Interview with [anonymized], July 2013, Malabo, Equatorial Guinea. 
selling all sorts of goods, and almost all are in their hands." 100 These merchant shops openly catered almost exclusively to a clientele of wholesale brandy and tobacco smugglers from the Cross River delta and the Wouri estuary who sailed to the island on large ocean-going canoe convoys. By the 1950s they had orchestrated the largest contraband smuggling network in coastal West Africa. ${ }^{101}$

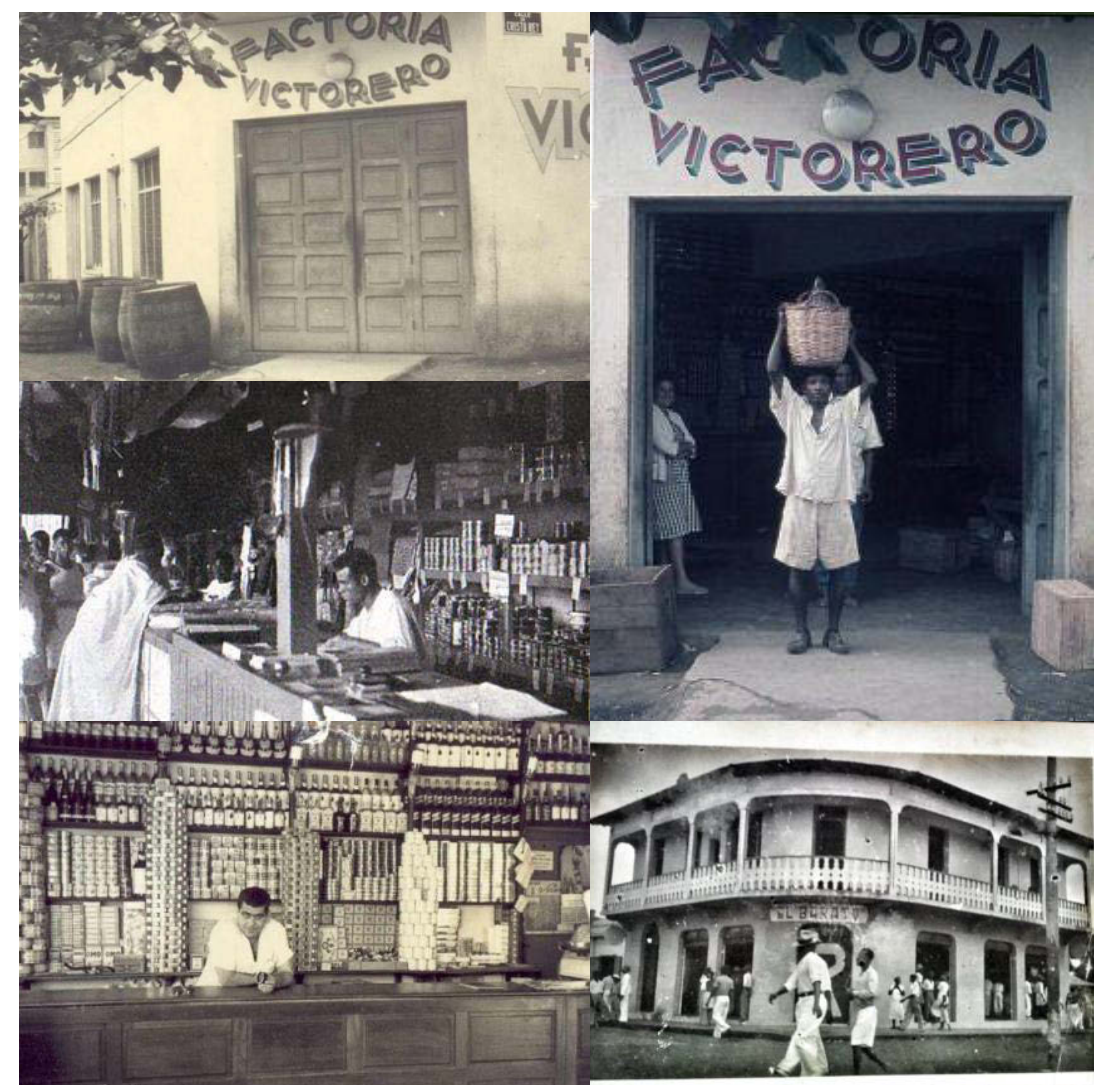

Figure 14 Factorias in Santa Isabel, Francoist period ${ }^{102}$

${ }^{100}$ Pozanco, Guinea mártir, 25. In the 1960s there were about 1500 employed in "commerce" in Rio Muni and 1000 in Fernando Po. This was the largest European population in Africa outside of Rhodesia and Angola. Spanish working for less wages than Europeans elsewhere in colonies, but three times the wage rate in Spain. Pélissier, Los territorios españoles de Africa, 46, 75.

101،Smuggling - Nigeria’s curse’, Drum, January 1961.

${ }^{102}$ Clockwise from top left, images are captioned by the settlers who posted them: '1964. chaflan exterior a la derecha calle Cristo Rey'; '1964. interior de factoria Victorero mi padre a la espera de clientes'; 'Factoria y era de un nativo de Nigeria, que se llamaba Okon. Año, (puede), 1955'. Images from http://bioko.net/galeriaFA/, searched 'factoria' and 'Victorero'; except bottom right, 'El Barato' from Kicks-Dadzie to Resident, Calabar, September 1939, 'Confidential Report: Labour in Fernando Poo', NAE, CALPROF 5/1/195 


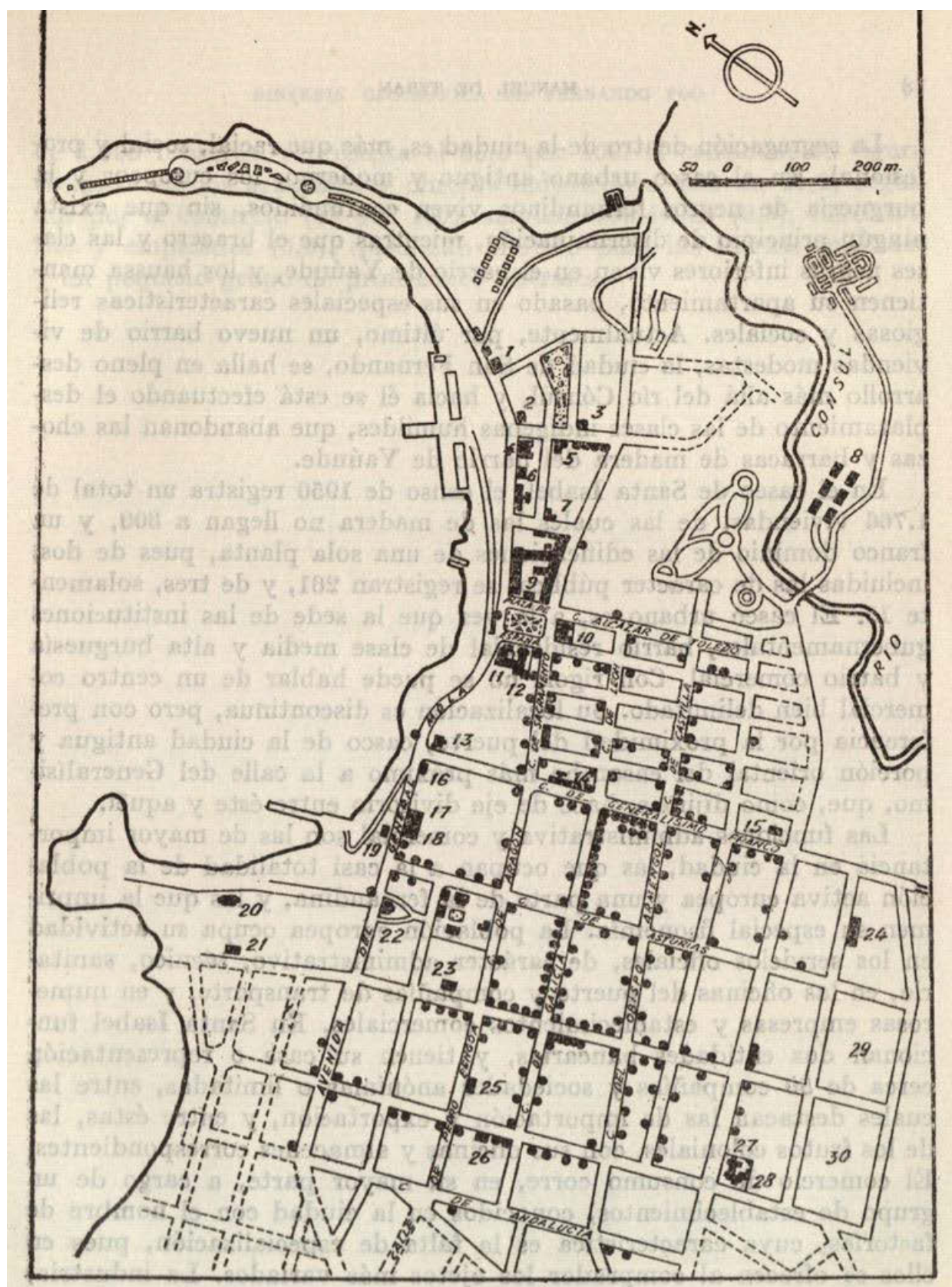

Fig. 15.-Plano de Santa Isabel. Los puntos representan establecimientos comerciales. Los números se refieren a edificios de carácter religioso y administrativo, de enseñanza, sanidad y otros servicios públicos, cuya relación se especifica a continuación: 1. Guardia Territorial. 2. Secretariado General. 3. Delegación de Trabajo. 4. Delegación de Hacienda. 5. Caja Provincial de Seguros. 6. Comandancia de Marina. 7. Junta de Importación y Exportación. 8. Hospital General. 9. Misión Católica, 10. Gobierno General. 11. Palacio Arzobispal. 12. Catedral. 13. Compañía Iberia de Aviación. 14. Grupo escolar. 15. Delegación de Asuntos Indígenas. 16. Policía Gubernativa. 17. Instituto de Enseñanza Media. 18. Tribunales de Justicia. 19. Compañía Trasmediterránea. 20. Obras Públicas. 21. Construcciones Urbanas. 22. Cámara Agrícola. 23. Ayuntamiento. 24, 25 y 26. Sanidad Provincial (almacenes). 27. Inspección de Industrias. 28. Registro de la Propiedad.

Map 6 Santa Isabel, 1950s; each dot is one factoria ${ }^{103}$

${ }^{103}$ Terán, Síntesis geográfica, 60. 
While on a fundraising tour in Santa Isabel the secretary of the Ibo State Union whose members on the island were being continuously arrested, beaten and deportedremarked that "it is truly a 'market country', throughout the island one can scarcely distinguish the shop fronts from the government offices. In its entirety it is filled with gigantic mansions and warehouses with innumerable merchandise for sale". ${ }^{104}$ In "reality, the Ibo went for two reasons: to make money and to take advantage of the opportunities the island presented for smuggling." The "return trip" of the "great sea canoes filled with Africans being taken to Fernando Po for illicit engagement" were "laden to the gunnels with brandy, guns and trade good for sale in Nigeria. Labourers also at the end of their contract shipped contraband." ${ }^{105}$ After the contract, under certain circumstances, it was possible to obtain "a trading license", which allowed a braceros with an finished contract to stay for a month without being picked up by police. $^{106}$

The dash was also being poured into expensive "bicycles and gramophones" or Spanish-made "sewing machines, before returning home". ${ }^{107}$ Labourers made it "clear" to anyone who asked them that the "principal attraction of [a] term of employment in Fernando Poo [was] the acquisition of a lump sum"- "the inability of the individual to save when employed in Nigeria on even well paid work is well known". ${ }^{108}$ One "Mr. Chinebu Echu, from Okigwi" after returning from four years of contract labour "from Fernando Poo's cocoa and coffee plantations" told a journalist

\footnotetext{
${ }^{104}$ Ibo State Union, Delegation to Fernando Poo, 1954, AGA, C-81/08223 E-1. See van den Bersselaar, "Creating "Union Ibo"'.

${ }^{105}$ Ian Brook, The One-Eyed Man Is King (London: Cassell, 1966), 196. This is the autobiography of the Ian Brinkworth, artist, solider and eventually District Officer in Eastern Nigeria.

${ }^{106}$ British Consul, Yaounde, 4 May 1961 'Extract from Yaounde Despatch No.46', TNA, CO 554/2502.

${ }^{107}$ British VC and LO (Bradley) to Commissioner of Labour, Lagos, 14 April 1953, 'Annual Report', TNA, FO 371/102612; Gabriel B. Hart, 'Public Opinion: Recruitment For Fernando Po Labour', Nigerian Daily Standard, Lagos, 30 July 1957; see also Ríos, La España ignorada, 55; Adro Xavier, España en Africa: ayer y hoy (Barcelona: Ferma, 1960), 16.

${ }^{108}$ Minister of Labour, Lagos, 18 January 1956, 'Report of the Federal Minister of Labour and Welfare on visit to Fernando Poo, 4th-8th January 1956', TNA, CO 554/1346.
} 
that "the conditions" on the plantations "were fine", he was even considering "heading off again to said place." Echu had managed to earn "some $35 £$ ", because, he said, "there was also a bonus given by employers" and indeed "every labourer receives this bonus." 109

One of the Vice Consul's informants gave him the impression that "the majority of labourers, on receiving the lump sum bonus on contracting, paid a large part of it over to a woman and this gave them the right to spend the night with her, whenever they came to Santa Isabel". ${ }^{110}$ This was only partially true; she was more than a prostitute. Several thousand Nigerian and Cameroonian women ran and staffed the market-stalls, and brothels and bars that populated $\mathrm{Nu}$ Billi (New Village) or Campo Yaounde - the migrant slum of Santa Isabel. ${ }^{111}$ These women acted as the so-called 'money-keepers' accounted for elsewhere in West Africa, because informal dash money was obviously unbankable. ${ }^{112}$ The peseta lost fourfold its value vis-à-vis the West Africa pound between 1936 and 1952, so it made sense to quickly convert the dash into fixed assets such as liquor bottles that could eventually be smuggled back and easily sold in Nigeria - a delayed conversion usually arranged by these women.

\footnotetext{
${ }^{109}$ ‘Fernando Poo’, Eastern Nigeria Guardian, Port Harcourt, 14 August 1957.

${ }^{110}$ British VC and LO (Bradley) to Commissioner of Labour, Lagos, 14 April 1953, 'Annual Report', TNA, FO 371/102612.
}

${ }^{111}$ Policía, Entry of 28 September 1953, 'Registro de Incidencias 1953', 278, BNM; Paul Iregbulam, Jefe de los Ibos Owerri, Santa Isabel to Administración Territorial, Santa Isabel, 14 December 1955, AGA, C-81/08601, E-5.

${ }^{112}$ Berry, 'Stable Prices, Unstable Values', 309; Gustav Peebles, 'Rehabilitating the Hoard: The Social Dynamics of Unbanking in Africa and Beyond', Africa 84, 4 (2014): 595-613; Guyer, 'Gains and Losses in the Margins of Time', 148. 


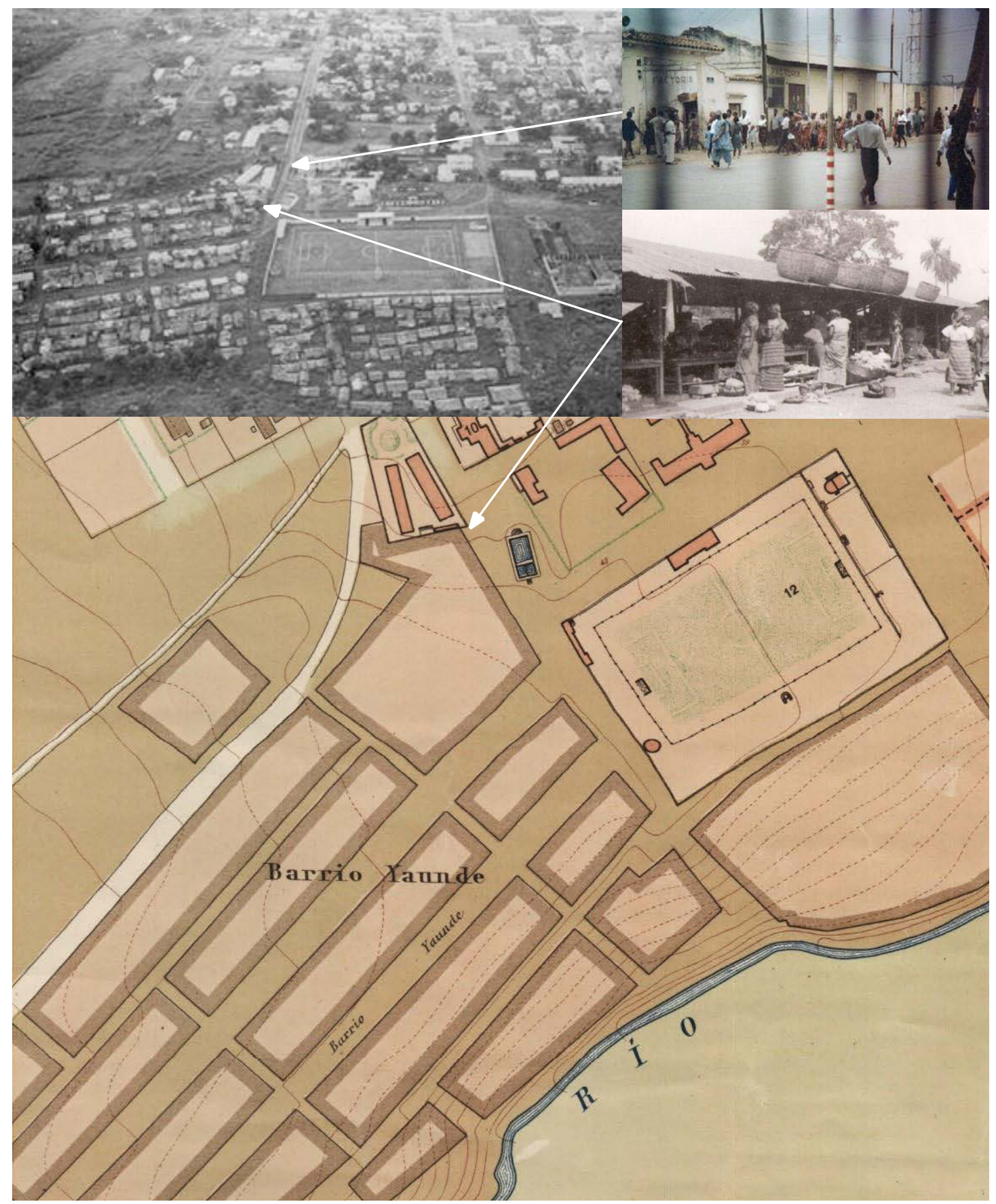

Figure 15 Campo Yaounde, Francoist period ${ }^{113}$

${ }^{113}$ Variously also Campo or Barrio Yaunde. "Campo Hausa" was to the left of the image. Photographs gathered from http://bioko.net/galeriaFA/. Inset from Map: Ramon Izquierdo Cotorruelo, 'Planos de Población' (Madrid: Talleres del Instituto Geográfico y Catastral, 1946), BNE, AFRMPS/20/1017. See also Severo Moto Nsa, 'New Ville, Alias Campo Yaounde', Diario de la Guinea Ecuatorial, Santa Isabel, 5 December 1972. 
Braceros never actually held on to the dash money for long. Keeping unattended valuables in the housing barracks of the plantations was not a good idea-theft was common. ${ }^{114}$ Also, as there were no official receipts for dashes braceros would avoid carrying around large sums of cash for fear of being accused of theft and immediately thrown into jail-beaten and thrown onto the road-gangs of the public works department. $^{115}$

In the 1930s in the wake of the Great Depression, large groups of West African traders started appearing on the island to engage in a range of licensed and unlicensed money making activities in the towns and outside the plantation patios. Santa Isabel, was a key node strung along the West African steamship routes. The mostly Nigerian passengers on the steamships were by and large itinerant self-employed traders or those who joined friends and family engaging in various stripes of informal economic

\footnotetext{
${ }^{114}$ Curaduría (Llompart) to GG (Bonelli), 29 November 1946, AMAE, R2370, E-11; AT Santa Isabel, 'Palabra Civiles', 1938-1958, AGA, C-81/08530 to AGA, 81/08545. Theft of each other's possessions was clearly marked off from the appropriation of planters' property: "It seems that the saying that there is honour amongst thieves is very apt in this case, for whereas all labourers seem to consider robbing their employers as all in a day's work, they do not rob each other with the same monotonous regularity". British VC and LO (Bradley) to Commissioner of Labour, Lagos, 31 March 1950, 'Labour Report No.1/1950', TNA CO 554/169/1.
}

${ }^{115}$ In 1962, two braceros, Amureke Uwualaka and Waite Rugus, "died under strange circumstance". They had been beaten to death by the Guardia Colonial after being accused and "confessing" a substantial theft in order "to disclose where they hid the stolen goods". The "European in charge of the plantation" had called the Guardia in and himself started "kicking" the two accused while they were being held down. "After this interrogation, everyone had something to eat, and the braceros ingested large amounts of gari and water, and only felt sick after their meal. It should be noted that what is being recounted is based exclusively on the testimony of the two Guardias Territoriales and the European in charge." Note taken. This time the "autopsy report" actually documented the "signs of having been tied up by the arms, and the imprints of the melongo [whip] on their lower back, and a variety of violently inflicted wounds throughout the body" yet the Spanish medic still insisted that "the death could conceivably have been caused through the ingesting of large amounts of food." GG (Núñez), 27 February 1963, 'Fallecimiento de dos obreros nigerianos en Puerto Iradier', AGA, C-81/08935, E-s/n 864. "In September, 1962, a labourer in our farm was accused of stealing some amount of money and this labourer my husband's name as one of his associates in the crime. The soliders came afterwards and arrested my husband, the man who mentioned his name and another labourer. The solidiers took them away and later brought them them to the farm and after severe beatings, my husband and and the other labourer by name Rufus died as a result of the beatings on the spot. While the soldiers were beating my husband and the other men, with their hands tied together behind them with wire ropes, my husband's European big master called Ramon trampled on the stomach of my husband and joined the soldiers in beating my husband to death. The two men died in the presence of the European Ramon. Later their dead bodies were carried in a launch to the hospital at Kogo. I understand that the three soldiers and the labourer who mentioned my husband as his accomplice are now detained in the Benito and Bata prisons respectively. I was taken to Kogo to give evidenc and later to Bata to give evidence. I do not know whether the soldiers are imprisoned or not." Virginia Uwalaka, 1963, "Statement made in this Consulate by Mrs. Virginia Uwalaka, wife to the late Amukere Uwalaka', AGA, C-81/08935, E-s/n 864. 
activity on the island. An observer from Santa Isabel in 1934 says that the "freedom to access our Colony could not be greater, whoever disembarks on our shores does not experience any discomfort except that of hopping off the steamer". ${ }^{116}$ These new migrants partly catered to the needs of braceros, who on Sundays were "given ample liberty to visit the many bars and vagabond women of the Island, the principal import from Spain is a cheap wine chiefly for indigenous consumption."117

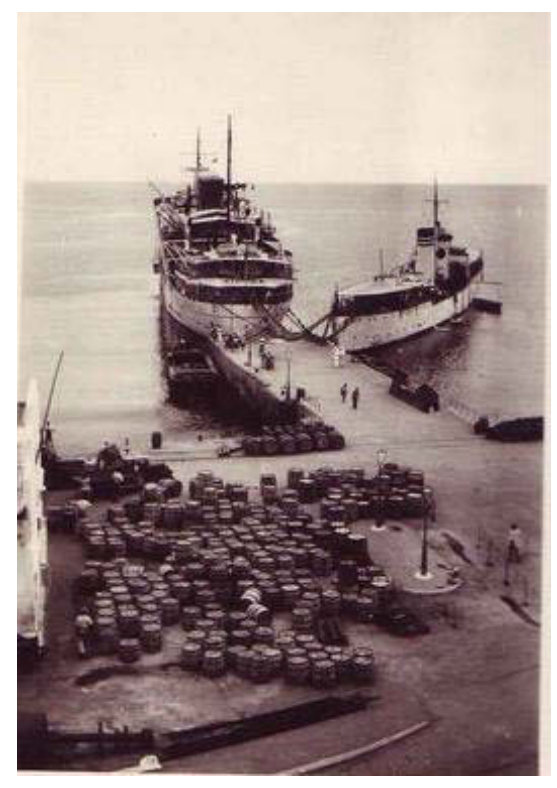

Figure 16 Imported wine barrels at Santa Isabel harbour, 1930s ${ }^{118}$

A British missionary, responsible for a mostly Nigerian congregation in an isolated plantation area, noted in 1934 that "lots have been terribly disillusioned and suffer terribly from home-sickness. Behind them they have left their families, parents, tribal chiefs, laws and restraints [and here] except to their employers and the country laws, have no other allegiances. Soon they acquire new sins and vices." ${ }^{119}$ Many braceros

\footnotetext{
${ }^{116}$ Jefe de Policía to GG (Manresa), 15 March 1934, AGA, C-81/08146, E-1.

${ }^{117}$ Curaduría (Romain Ordoño) to GG (Manresa), 16 July 1931, AGA, C-81/08125, E-2. For those of Victorian sentiment this was a "state of freedom. There are plenty of cafes and idle women on the island, and the chief import from Spain is a crude wine for native consumption only." Murray, The School in the Bush, 25.

${ }^{118} \mathrm{http}: / /$ bioko.net/galeriaFA/, searched 'puerto'. Site has no permalinks.

${ }^{119}$ W.H. Collins 'Fernando Poo To-day: A weekend visit to San Carlos by Rev. W.H. Collins', in Kingdom Overseas, 2 (1934), 222.
} 
themselves, at the end of the working day earned well from participating in the informal economies of the island; "producing charcoal"120, engaging in the "theft of firewood [to bring] to the town for sale", ${ }^{121}$ catching crabs from the innumerable rivers streaming down the volcanic slopes and selling them to drivers on the road, or gathering fruits from the shadow trees of the plantation. These activities were often followed by the accusation of "alleged robbery". ${ }^{122}$ It should be emphasized that in colonial work sites in Africa as elsewhere, this type of informal economies, leveraging and pilfering was "certainly did not considered [to be] criminal behaviour"; those involved in it "talked openly about forging exchange and selling networks." 123

Given the commercial intensity of the island it was unsurprising that braceros were "tempted to fritter away" the "ill-gotten gains" of the dash on "wine, women and tobacco". While "the more prudent of them", says the Vice Consul, "invest the money in goods with which to trade on their return to Nigeria". ${ }^{124}$ The Methodist Reverend on the island lamented that his churches were being "neglected" because the bracero went on Sunday shopping trips to "spend his money in shops [with] fine displays offering a bewildering variety of cheap Spanish drinks", for export and consumption. ${ }^{125}$ In a rare archival find, the confiscated diary of a bracero, a politically

${ }^{120}$ British LO (Evans) to British Consul General (Lawrence), Duala, 31 July 1945, 'Labour Report No.17', NAE, CALPROF 17/1/278; "sold a sack for 20pts for which the master had him beaten. Manager fined 100pts".

${ }^{121}$ British LO (Evans) to British Consul General (Lawrence), Douala, 31 August 1945, 'Labour Report No.18', NAE, CALPROF 17/1/278.

${ }^{122}$ British LO (Evans), 30 April 1945, 'Native Labour, Monthly Report, No. 14', TNA, FO 371/49598. The "stealing of coffee beans form the plantations" was a systematic affair, these could be sold on to a highly organized underground circuit of Hausa intermediaries.

${ }^{123}$ Ralph Callebert, 'Cleaning the Wharves: Pilferage, Bribery, and Social Connections on the Durban Docks in the 1950s', Canadian Journal of African Studies 46, 1 (2012): 23-38, 26; Harries, Work, Culture, and Identity, 114; William Freund, 'Theft and Social Protest Among the Tin Miners of Northern Nigeria', Radical History Review 26 (1982): 68-86.

${ }^{124}$ British VC and LO (Bradley) to Commissioner of Labour, Lagos, 31 March 1950, 'Labour Report No.1/1950', TNA CO 554/169/1.

${ }^{125}$ David Lawrence, (unpublished memoirs, 1999), 'Faith Hope Love: A Legacy', 42, SOAS, MMS, MMSL MSS/028. 
conscious and torn convert, a young unmarried man called Monde, reads: "Shameful, I had over doze shots of illicit gin and palm oil wine and adultered and woke up to 12 noon at the premises in the Afonta local Bar. My action when I was very high was rewarded as madmans way of life". ${ }^{126}$ Those with the certain type of nerve to stay on the island for several contracts, says Israel, a former treaty-bracero, were given the appellative "griho": "this simply means that those people were carried away by the high life in Fernando Po that existed in the form of women and alcohol". ${ }^{27}$

In the mid-twentieth century a colonial accountant found himself somewhat anxious by the fact that the "custom of the pequeño regalo" had become the "single largest expenditure" for running a plantation: the dash was having an antagonistic seizure with obvious "repercussion on the costs of production". ${ }^{128}$ When in 1952 the dash had "risen to amounts oscillating between 6000 and 7000 pesetas the benefits of the harvest [were] squarely falling into the hands of the braceros themselves or to the intermediaries who intervene on their behalf." The convulsion and acceleration of the dash was paid for by large Spanish and capital-rich corporate plantations who were the ones "needing a large amount of braceros and constantly renewing the contracts of their recruits". ${ }^{129}$ Until the early 1950s these hegemonic planters were busy fuelling the dash in order to drown out the undercapitalized small farms owned by Spaniards, Portuguese and Fernandinos, who had not been "able to stand the pace" of the dash and had "no alternative but to sell out to the larger concerns". ${ }^{130}$ Only during "peak-

\footnotetext{
${ }^{126}$ Monde Obongue, 15 October 1961, 'Annals 1961' [Diary booklet], AGA, C-81/08803, E-622.

${ }^{127}$ Oham, 'Labor Migration from Southeastern Nigeria to Spanish Fernando Po', 62. Griho may have been a nickname derived from the Spanish word for cricket, grillo, the noisy and night-alert creature.

${ }^{128}$ Delegacion de Hacienda, Santa Isabel to GG, n.d. [1950-1951] 'Oficio Num. 150', AGA, C81/12373, E-392.

${ }^{129}$ Vicepresidente del Comite Sindical del Cacao, Barcelona to DGMC (Díaz de Villegas), 5 May 1952, AGA, C-81/12373, E-392.

${ }^{130}$ British VC and LO (Bradley) to Commissioner of Labour, Lagos, 10 April 1951, 'Report No.1/1951', TNA, CO 554/169/2.
} 
dash' in June 1952 did the Cámara call upon the Governor to "resolutely intervene in order to cut the rising costs of labour in its tracks." 131

Within three weeks the Spanish colonial authorities had "put in motion a study to wipe out the escalating regalo", but they found that they could not get rid of it. They partially rearranged it into a registered bonus, into a reduced "lump sum paid out only at the end of a contract, [because] the total suppression of the prima would have completely paralyzed the agriculture of the island." The Vice Consul gathered that braceros "did not take to this new method at all".132 Those "who completed their contracts had no interest in staying" on the island because their "calculations or estimation of the regalo were no longer being taken into account". ${ }^{133} \mathrm{New}$ dash prohibitions notwithstanding, over a third of the planters continued to pay upfront and off-the-books to subsist; otherwise they were simply unable to harvest their crop. Indeed, to subsist during the Francoist period many of these smaller planters had to rely on touts as they were being excluded from "treaty-labour" by the more powerful Spanish planters. This group of local tout-dependant planters made up over a third of employers. The labour treaty with the British colonial state gave the Spanish-only executive committee of the Cámara a monopoly to "fairly distribute and allocate" any new braceros arriving from Nigeria, but the growing number of cheaper "treatylabour" was "blatantly" directed to the Cámara's own members. No new braceros were "allocated to foreigners", and "very very few to Spanish emancipated natives", so the large Portuguese and German plantations and the Fernandino and Bubi

${ }^{131}$ Vicepresidente del Comite Sindical del Cacao, Barcelona to DGMC, 5 May 1952, AGA, C81/12373, E-392.

${ }^{132} \mathrm{GG}$ (Ruíz) to DGMC (Díaz de Villegas), 17 June 1952, AGA, C-81/12373, E-392; British VC and LO (Bradley) to Consul General, Barcelona, 4 July 1952, 'Report No.2/1952', TNA, FO 371/96714. For treaty-workers the bonus was even being paid out in Calabar at the end of their contract. "A man returning after a two year contract usually received about $£ 20$ in cash on arrival in Calabar; after a double contract of 42 months in all." "Deferred wages are paid into an account in Calabar controlled by the Department of Labour. The current balance awaiting disbursement on the return of the labourers concerned is $£ 117,000$.”

${ }^{133}$ Llompart Aulet, 'Nigerianos en las provincias ecuatoriales', 68. The decline in numbers was attributed to the "electoral politics of Nigeria," as the Spanish were fond of saying, when newspaper scandals and politicians came out against Fernando Poo. Comisión para el Desarrollo Económico de Fernando Poo y Rio Muni, 'Plan de desarrollo económico de la Guinea Ecuatorial: 1964-1967', 233, BNM. 
farmers - about a hundred or so who usually only had one bracero under contracthad to "rely on retaining their pre-treaty labour or obtaining illegal labour [or deserters] in order to carry on". ${ }^{134}$ If medium-sized Fernandino planters of very diverse backgrounds dominated agriculture in the early twentieth century, then by the first decade of Francoist rule, bar a handful of exceptions, ${ }^{135}$ they were wiped out. ${ }^{136}$ The planter class always in motion, agglomerating and disappearing, the island underwent a mitotic spindle, and soon "employers" were all large "Spaniards and workers [were] all Nigerian." In 1958 someone writing for the magazine West Africa based out of London supposed that there was "probably no other territory in the world so completely dependent upon immigrant labour."137 ${ }^{134}$ British VC and LO (Spencer-Cooke) to Commissioner of Labour, Lagos, 30 September 1950,
'Labour Report for the period 1st of July to 30th September 1950', TNA, FO 371/89597; British VC
and LO (Spencer-Cooke) to Consul-General, Barcelona, 8 November 1950, 'Report on the existing
Labour conditions in the Spanish Territories of the Gulf of Guinea', TNA, FO 371/89597.

${ }^{135}$ See of course the Joneses, no one could keep up with them. San Carlos was known for its Fernandino agriculture, but even this was the situation in the early 1940s: The biggest planters were Libanio Vaz Serra with 1300h; Veiga y Avendano with 1200 hectares; Antonio Perez with 850h, Casa Drumen with 582 Hectares, Mera y Compañia with 500h; Comapañia Colonial de Africa with 500h, and of course the Herederos de Maximiliano Jones with $280 \mathrm{~h}$. Only the last were Fernandino. The 40 European plantations in San Carlos employed over 8000 braceros, each between 20 to 700 braceros. While only 4 plantations of emancipados (excluding Jones) hired about 60 Nigerian Treaty labourers on some 200 hectares. AT San Carlos, 1944-1949, 'Movimiento de braceros: estadistica Delegación de trabajo', AGA, C-81/08129, E-4.

\begin{abstract}
${ }^{136}$ Clarence-Smith, 'African and European Cocoa Producers on Fernando Poo', 199. In 1940, 26,340h or seventy-one per cent of land under cultivation was under the control of Europeans, and 10,600h or twenty-nine per cent by Africans. There were some 270 cacao producers, one hundred of whom did not employ migrant labour. Wolff, 'Ein Beitrag zur Wirtschaft von Fernando Poo', 93. In the late 1950s about 400 Bubi and Fernandino farmers remained, hiring about one labourer each, see complete table at Curaduría, 1957, 'Relacion de trabajadores nigerianos actualmente contratados con las empresas que se mencionan en la provincial de Fernando Poo', AGA, C-81/08667. They were also decimated through systematic fines. The most common fine for employers was not "depositing $50 \%$ of the income of braceros in the prescribed intervals," a deposit system where half of the wages were banked by the Labour Officer and only paid out at the expiration of the contract. This unconditional and obligatory arrangement was officially to guarantee final payment but was also clearly made to disincentivize desertions. And while fines were small, thousands of pesetas were racked in monthly, with practically the entirety of the many hundred smaller Bubi, Fernando and Liberian farmers penalized for running their plantations on credit, and having liquidity only after the sale of a crop to one of the commercial houses. Delegado de Haciendo to GG (Alonso), 30 November 1942, 'Sanciones por incumplimiento de la Orden de 4 de Agosto de 1942', AGA, C-81/08128, E-13.
\end{abstract}

${ }^{137}$ 'Nigeria over the Water’, West Africa, London, 1 January 1958. 


\subsection{Dash Desertion: Fugados}

The 1952 decree that tried to ban dashes was also explicitly geared "to stop labourers deserting and recontracting, under false names, with false documents in order to obtain the engagement bonus". ${ }^{138}$ Deserters "appeared to consider that the risk of breaking the law is well worth the 'dash', which they would receive for contracting, if they were not caught". ${ }^{139}$ The labour market into which the fugados inserted themselves into was characterized by an excess of paperwork. It was a costly routine, but a routine nevertheless, to acquire paperwork in the different labour, medical and police departments and fill the pockets of one of the "at least 400 functionaries who easily succumb to the temptation to falsify a paper or document as soon as the opportunity presents itself." ${ }^{140}$ Marck Oturu, a Nigerian recruiter-tout from Bende who was "inscribed as a peddler residing in this city", was arrested and held in the police headquarters of Santa Isabel and assured the new Spanish Chief of Police in 1961 that any "necessary paperwork could all be arranged for here" in Santa Isabel. ${ }^{141}$ Deserting reenganchos again enlisted the collaboration of $N u$ Billi's bar owners, who "protect[ed] fugados in their homes" when they needed to await a supply of new

${ }^{138} \mathrm{GG}$ (Ruíz), 12 May 1952, 'Ordenanza prohibiendo las primas o regalos en la contratacion', Boletin Oficial de los Territorios Españoles del Golfo de Guinea; Negociado de Estadística del Gobierno General, Resúmenes Estadísticos, 221; British VC and LO (Bradley) to Commissioner of Labour, Lagos, 14 April 1953, 'Annual Report', TNA, FO 371/102612.

${ }^{139}$ British VC and LO (Bradley) to British Consul General, Barcelona , 4 January 1952 'Report No.4/1951', TNA, FO 371/96714.

${ }^{140}$ Romero Moliner, 'Apuntes sobre la estructura social de Fernando Poo', 43. A settler in 1936 makes the judgement that the Fernandinos, the "landowners" the "elite caste" of English-speaking and Protestant Fernandino who "feel hate for Spain", nevertheless "for inexplicable reasons make up the greater part of African staff in out colonial bureaucracy". Babiloni Navarro, 'Los territorios españoles', AGA, C-81/12427.

${ }^{141}$ Jefe de Policía (Jaime) to GG (Ruíz), 22 June 1961, AGA, C-81/08215, E-5. For example Gowdin Amadi of Owerri, explained that he had turned up at the Agency in Calabar, penniless, he was turned back by the medical officer, possibly due to being under the age of 16 , he was given " 9 shillings and two pence to return to his village whence he accidentally met MARCK OTURU" whom he told he wished to go to the island but was penniless, to which "said gentleman promised him help for $20 £$ to be returned once he's earned wages on Fernando Po, which he gladly accepted". Another illegal recruit, Sunday Akpan, said this paying of fees to transport brokers and illegal recruiters was consensually arranged: "he acknowledges that he was helped when brought here from Calabar." 
paperwork. ${ }^{142}$ Ganchos prescribed, brokered or sold any supporting documentation to deserting labourers. This was usually arranged beforehand, because the "detaining of immigrants without the appropriate papers" was almost instant. Dozens of detachments and road-blocks of the militarized police, the Guardia Colonial, were placed around the only road that by the 1940s had encircled the island - a road largely built and maintained by imprisoned Nigerian braceros. ${ }^{143}$ In the late 1930 s the Curaduría had 17 staff_- desk clerks, guards, a driver, a cashier and a separate guard for the catching of braceros fugados. The Curaduria had its own handful of police officers too with wide-ranging powers to raid all homes and plantation patios without notice: so as to "keep in continuous fear the braceros fugados o maleantes". ${ }^{144}$ The

\footnotetext{
${ }^{142}$ Policía, 'Registro de Incidencias 1953', entry of 9 August 1953, page 174, BNM; In the 1950s the colonial authorities started delegating the task of finding fugados to eight Nigerian "chiefs" in Campo Yaounde, and who for denouncing fugados and vagos, keep a third of the fine. The Campo chiefs of were also at the behest of the local administration, and would organized, "without pay" and "against their will" the sending of "Ibos and Calabares" to do "cleaning jobs and chapeo" in the slum. AT Santa Isabel to GG (Bonelli), 15 May 1946, 'Campo Yaounde', AGA, C-81/08601, E-1. By the 1960s dozens more Nigerian chiefs were appointed, "to fulfil the laws of Public Order, especially amongst the Nigerian population." They "were authorized to arrest any delinquent, bringing them to the Police or to the courts", see 'Nine Nigerian "Chiefs" appointed in Fernando Poo', Daily Times, Lagos, 22 August 1958.
}

${ }^{143}$ GG, 25 September 1963, 'Circulares Indocumentados', AGA, C-81/08781, E-3; In Francoist Fernando Pó, just the series of jails run by the Guardia Colonial housed between 600 and 1000 inmates a day. Guardia Colonial, 1950, 'Memoria', AGA, C- 81/08183. In San Carlos the "number of prisoners driven" per day in 1955 ranged between 300 to 500. Guardia Colonial, 1955, AGA, C-81/15865, E-9. In San Carlos this is out of a population of 8500 contracts workers, 7500 of whom were Nigerian, 800 Spanish and 430 'French'. Prisoners being driven in labour gangs would desert quite regularly, like clock-work: "at the end of the work day at $7 \mathrm{pm}$ when we take them to rinse themselves off by the water they always manage to fugarse".

${ }^{144}$ Curaduría, 1936, 'Inventario', AGA, C-81/08126, E-28. Curaduría, September 1934, 'Reglamento de la Policía de Curaduría', AGA, C-81/07722 E-1. Eight guards supervised the forced labour of those arrested on vagrancy charges in a floating jail population of 80-150 braceros. Most braceros were held by the Guardia Colonial who also had many outposts on the island. While the colonial Ley de Vagos y Maleantes was almost identical to the one passed in early twentieth century Spain, the only modification, the colonial adaptation, the mark of the extension to the plantation complex, was the clause, at the service of employers, specifying desertion. The extra clause for the fugitives, the fugados "those, who are under contract and escape without a justified cause [and who] show an aversion to labour", reflects the labour scarcity on the island as well as the power of the planters. Planter power is also evidenced by the comparatively reduced sentences or "correctives", of being "interned in an establishment for the regime of labour, for no less than a month, nor more than a year"-in Spain vagrants were interned for two to four years. Indeed the penal sanction for runaways in the first labour code of 1906 specified that "once recaptured the fugado will suffer a correction that shall not exceed ten days in jail", and shall then be "reintegrated" into their place of "work". GG (Sánchez), 1 September 1936, 'Ordenanza del 22 Agosto 1936. Vagos y Maleantes. Normas', Boletin Oficial de la Colonia. In Spain sentences for forced internment into labour camps were one to four years; GG, 1906, 'Reglamento del Trabajo Indígena', Art. 72. 
authorities did not pick up figures for desertion consistently, though it tended to be over $3 \%$ and less than $10 \%$ of the workforce. Nevertheless, even in the 1960 s the "principal problem" was still "related to, above all, the breach of contract" that is desertion; statistically desertion was aggregated under "absenteeism", which according to the calculations of one colonial economist constituted an average of "5 days a month per worker" or " $15 \%$ " of total labour time. This colonial economist collapses the categories of deserters and absenteeism in order to cloud the realities of desertion; in fact desertion was also distributed, diffused and counted along the other "problems" related to contract labour: "punctuality, theft, and the non-return of debts," when workers tried to cut short their contracts with the advances. ${ }^{145}$

The detachments and road-blocks of the Guardia Colonial also served as place where planters could punish their workers. The longest serving British Consul, Bradley, sympathised with the "employer, [who] quite rightly, considered that his eight labourers were idling their time away. He took them round to the local post of the Guardia Colonial and persuaded a soldier to beat them." ${ }^{146}$ The British Vice Consul, Spencer-Cooke, opined in 1950 that the "award of arbitrary sentences [on] workmen [who] are insubordinate or act in any malicious manner on a farm is possibly deserved". Spencer-Cooke was talking about the most elementary-and the most powerful - act of resistance: refusal; to decline. Off "the victim goes to prison where I understand he is greeted with a flogging as a preliminary to serving his sentence."147 One of the first active labour inspectors in the Francoist period-almost half a decade after they taken power-observed in 1941 that in the plantations of the Compañia Colonial de Africa a twelve hour working days where the norm, but "the work day has been reduced to ten hours". There were "corporal punishments, especially the

\footnotetext{
${ }^{145}$ Velarde Fuentes, 'Problemas de Empleo', 174.

${ }^{146}$ British VC and LO (Bradley) to Commissioner of Labour, Lagos, 2 January 1952, 'Report No.4/1951', TNA, 371/96714. He continues "The men concerned stated that they each received 50 strokes but the employer and the solider stated they had each received 5 strokes. As there were no marks on the bodies of the men concerned, I believe the employer's and solidier's version."

${ }^{147}$ British VC (Spencer-Cooke) to Consul-General, Barcelona, 8 November 1950, 'Report on the existing Labour conditions in the Spanish Territories of the Gulf of Guinea', TNA, FO 371/89597; "[C]orporal punishment invariably administered on entry into the prison", British VC and LO (Spencer-Cooke) to Commissioner of Labour, Lagos, 30 September 1950, 'Labour Report for the period 1st of July to 30th September 1950', TNA, FO 371/89597.
} 
whipping of the braceros who are unwilling to work"- this was allowed, though it depended on the instrument and its ability to cause an irreversible bodily disfiguration. The inspector also observed that while braceros "were generally wellbehaved in order to avoid corporal punishments in the fincas" he proposed that "there is the pressing necessity of creating within all army outposts the brigadas de castigos [punishment brigades] employing the prisoners with heavy pickaxe and shovel work, which is what most upsets the indigena." The brigadas disciplinarias were spread out and revamped to an unprecedented extent under the Francoists. It is almost the first thing they did. ${ }^{148}$ The road-gangs of the public works department were indeed a place of dread. As an "agonish report from Nigerian boys" explains in 1938: "When we finish contract from each of his master's farm where there is hell, that's a bad master, and refused to go back there, they will put the boy or boys to jail". "Some are numerable in that road they call caratera [road] which is the worst of all punishments in Sta Isabel ... beating us to death by their policers with big rubber and to carry a heavy pan of stones, plenty boys have sick and died away". ${ }^{149}$

The terrain of value between capital and labour on Fernando Pó was often jarring, verging from absolute injustice to spectacular coups. Planters clawed back their profits by extending contracts and by adding to their length arbitrarily imposed jail time. A group of braceros told George Dove-Edwin, a Nigerian Krio lawyer visiting

\footnotetext{
${ }^{148}$ AT Santa Isabel to GG (Fontán), 17 December 1941, AGA, C-81/08128, E-13. The brigadas disciplinarias, the disciplinary brigades, were "special regime of regeneration [...] where indigenous delinquents are obliged to work", that were "dedicated to the maintenance of roads and tracks, or other works of analogous hardness." "Ord. GG. 18 Agosto 1936. REGIMEN PENITENCIARIO. Normas B.O. 1 septiembre', in Miranda Junco, Leyes coloniales, 1487; The prison was to become not only place of unrepentantly despotic systematic torture, but gruelling, infinite toil and torment. In the early 1960s when a governmental circular reached the Guardia Territorial, instructing them to withhold severe corporal punishment, the Governor quickly reissued a clarification: "An incorrect interpretation of the instruction of 9 of February (1961) it seems, has led to the festering among some prisoners of an apathy towards work, possibly caused by their false idea that they cannot in any case be subject to corporal punishment; such apathy results in a decreased work performance rendered by the inmates, which I am in no way willing to tolerate." He adds that those in charge of the "prison regime are my most effective collaborators; they are undertaking an aspect, of such transcendental importance for the policies that my Authority is developing in these Territories [...] and out of respect to my own position I can not consent to any deviation or passive resistance." El Delegado Gubernativo, Santa Isabel to GG (Ruíz), 28 March 1961, 'Instruccion sobre trato a los reclusos', AGA, C-81/08221, E-4.

${ }^{149}$ Anonymous, 19 July 1938, 'An agonish report from Nigerian boys to the above Captain of English man of war,' TNA, FO 371/22669. For a map of the road network on Fernando Po and details of the technicalities, kilograms of gravel per kilometre and the like, see El Ingeniero Jefe a GG (Fontán), 3 March 1938, 'Avance de un plan de carreteras en la isla de Fernando Poo', AGA, C-81/07796, E-2.
} 
his brother-in-law on the island, that "a note from anyone of their employers was sufficient not only to confine them in prison but for them to be treated as convicts"the sign of the 'convict' in Nigeria as elsewhere in colonial Africa was unmistakably that of penal labour. ${ }^{150}$ In addition "if a labourer's employer has any sort of grounds of complaint he can send the labourer along to the Police and have him soundly flogged." ${ }^{151}$ As Mateo Ríos, a Spanish sailor passing through the colony, notes in the early 1950s, there was "no need for brute force on the plantations" it was "sufficient to threaten the worker with dropping him off at the police station, and out of fear he returns to work. The barracoon de la Policia is a 'tabu', there he will be beaten with a rubber truncheon wrapped in leather for as long as the Guards wish, while they serve out a sentence of forced labour." ${ }^{\text {"152 }}$ There was plenty of insurgent push-back against capatazes or overseers - a good enough reason to desert.

The planter Jose Ramirez lodged a complaint: on a Sunday when it was "customary to have some festivities in the patios", he ordered "his braceros to go to sleep and rest for the next day, whose order they all obeyed without exception". But when Ramirez approached a rowdy room in one of the barracks "at this moment an unknown indigena, without prior warning and without an exchange of words, punched him in the face, bruising his left eye and nose." The protagonist of the low-blow surprise attack, was a young Cameroonian form Mamfe, a bracero from a nearby plantation. When arrested he "pretended to be drunk" while being held by the guards, and then "pretended that he needed to go wee"; he was actually "quite sober" as he "used the opportunity to flee." Caught again soon after his defence was alcohol: he had "stumbled upon a fellow countrywoman" and "with a guitar" in they sat "together drank a little, with seven others we drank four bottles of wine and one cognac bottle." But "indeed he did try to get away because he knew that if he disappeared the massa

${ }^{150}$ George Frederick Dove-Edwin to British VC (Robertson), 31 January 1944, NAE, CALPROF 17/1/277; British VC (Spencer-Cooke) to Consul-General, Barcelona, 8 November 1950, 'Report on', TNA, FO 371/89597. See Bernault and Roitman, A History of Prison and Confinement in Africa.

${ }^{151}$ British VC and LO (Rylands) to Commissioner of Labour, Lagos, 8 January 1947, NAE, CALPROF $17 / 1 / 278$.

${ }^{152}$ Ríos, La España ignorada, 55. 
whom he punched in the face would not be able to recognize or locate him."153 Only the massa could arrange for his pursuit - he was confident that none of his drinking companions would inform on him. Nevertheless, he got caught and was sent to the brigada disciplinaria for one year with a subsequent order of deportation, all of which he was forced to pay himself; returning destitute to Cameroon. This happened in 1954. Cases like these happened very regularly, though many came out the other end unscathed. For example, Jose Ocoyo from Calabar, who like almost everyone had signed a contract with an alias, a "bracero working for Casa Lampert" a German contractor, who was the "alleged author" of a "head-wound" inflicted "with a shovel" on "Mr. Garcia", the overseer or capataz. Ocoyo wisely "fled apparently to Santa Isabel", untracked, the Spanish police gave the vague markers of colonial memory: "approximately 35 years of age, heavy built and very dark."154

However, hitting the planters where it really hurts was someone who went by the female alias ${ }^{155}$ Okpara Anita. Anita fled back to Nigeria with a forged "freedom paper" and then proceeded to send a personal letter taunting his former employer "Mr. Pedro". While working a seemingly prime job at the recently inaugurated Pepsi-Cola bottling plant, he was temporarily entrusted to deliver an envelope, that allegedly contained 46.600 pesetas. ${ }^{156}$ From the safety of his own country, to which he had

${ }^{153}$ AT San Carlos (Matres Calvo), 25 January 1954, 'Atestado'; 'Atestado: Manifestacion de Edet Elachea', AGA, C-81/08215, E-5.

\footnotetext{
${ }^{154}$ Comandante de Puesto, Concepcion to AT San Carlos, 7 April 1941, AGA, 81/15865, E-11.

${ }^{155}$ In Fernando Pó and elsewhere in colonial Africa, the "very casual use of names" amongst "African labourers" was a pre-emptive defence grounded in wit and well-founded paranoia: "he fears that some unknown and probably oppressive use may be made of any information about himself which he may supply, and he therefore frequently purposely gives false particulars; he may even adopt a vulgar or indecent pseudonym as an excellent joke in the vernacular for the amusement of his fellows who alone understand it", Orde-Browne The African Labourer, 77. On aliases, and the flailing dialectics of fingerprints and photography (that were only implemented on Fernando Pó in the mid-1940s and even then in easily forgeable templates) as strategy against pass laws, see MacDonald, 'The Identity Thieves of the Indian Ocean', 254; MacDonald, 'Forging the Frontiers' 168; Nair, 'Dangerous Labour', 25; Singha, 'Settle, Mobilize, Verify', 175. For European and other imperial situations, see especially Allan Sekula, 'The Body and the Archive', October 39 (1986): 3-64. Breckenridge and Szreter, eds., Registration and Recognition.

${ }^{156}$ Jefe de Policía (Ramirez Togores) to Alfredo Jones Niger, Calabar, 24 January 1962, AGA, C81/08803, E-s/n 622. For an image of the Pepsi-Cola bottling plant in Spanish Guinea, see 'Fotografias Inaguracion Embotelladora El Cayuco', 1964, AGA, C-81/11850.
} 
"flyed away by avion"—or airplane, as he says in mix of Spanish and English—and insisting on the more or less ethical conduct of his operation, he says: "the money was given me by Master Pinga, not by night or hidden thing it is in day time." Like the dash, money changed hands in broad daylight, the cosmological opposite of stealth or night-time banditry. ${ }^{157}$ This practice of escalation and sabotage worked, importantly, only if performed with theatrics and props - with aliases, assumed identities, forgeries, and a stash of documents - in the plane light of day rather than through the stealth of the predatory lone burglar. ${ }^{158}$ If deemed just or worth the risk, a labourer could "contract himself to five different employers in the course of a month, each time receiving a handsome 'dash"”. "One man [who] had 13 current contracts" might have broken a record with all except one of his hopeful employers denouncing the bracero as a fugado. A "great many Treaty labourers" were also defecting to the spiralling dash by simply "adopting a new name". They "realise that if they run away and obtain false papers, which can be bought [they] receive a 'dash' of some $£ 30$ ". ${ }^{159}$ Ato Santos, an "Ijaw from Opobo" signed a treaty contract in Calabar but soon fled back "to Nigeria in a canoe" and two months later he came back "paid FIFTY PESETAS to a nurse of the Sanitary Services who gave him a medical certificate with

\footnotetext{
${ }^{157}$ Akpara Anita to Pedro de la Cia. Pepsi-Cola, 24 November 1961, AGA, C-81/08803, E-s/n 622. He then seems to suggest that his action of flight was the sublimation of the resentment of subordination into an outwitting manoeuvre that "end your higher knowledge", and that his act of flight would be vindicated by the added dash of respect that will accrue to workers in the employers' unease: "Through to years ill treatment in we black men end your higher knowledge have brought you to this point of heard I known which is always brother to master hate. This is simple when you see any black man working under you respect him through: to his colour." This last line is also somewhat cryptic, but another labourer, who was immediately deported after several months of hard labour for what he said, puts the gist of Akpara's letter more clearly - as paraphrased by the Police Chief: "its very easy to say yes to the orders that the Europeans give us, well because the only words of Spanish we have been taught are 'si señor', which one has to say even if you are thinking the opposite. In Nigeria this is not how it works, everyone responds man to man." Policía to Secretario General, 4 May 1962, AGA, C$81 / 08803$, E-s/n 622.
}

\footnotetext{
${ }^{158}$ See also Misty L. Bastian, 'Bloodhounds who have no Friends: Witcheraft and Locality in the Nigerian Popular Press', in Modernity and its Malcontents: Ritual and Power in Postcolonial Africa, ed. Jean Comaroff and John Comaroff (Chicago: University Of Chicago Press, 1993), 129-66, 154.

${ }^{159}$ British VC and LO (Bradley) to Commissioner of Labour, Lagos, 10 April 1951, 'Report No.1/1951', TNA, CO 554/169/2; British VC and LO (Bradley) to British Consul General, Barcelona, 4 July 1952, 'Report No.2/1952', TNA, FO 371/96714; British VC and LO (Rylands) to Commissioner of Labour, Lagos, 8 January 1947, NAE, CALPROF 17/1/278.
} 
this changed name" and with it he hired himself under the false name of "Patric Chinaka Alaga" to "another employer". ${ }^{160}$ He was unlucky to be caught.

The deserter-tout nexus reassembled with a vengeance by deploying some of the techniques of financial capitalism-generating speculative debts based on their labour - within a state of generalized corruption. Touts could not generate their own kingdom, only the knowledge of whom to approach and where to go. Touts - these self-schooled virtuosos of commercial life-were driven by their share of the dash, but they were also personally solicited as they enabled a radicalization of workers' strategies and expectations. Together they came up with an extraordinarily creative praxis, a co-operative but risky logistics, a tuning into ever widening relays of localized savoir-faire, the flaring open of loopholes, actively deploying but wholly indifferent to the preformatted rules of exchange. The devices that capital and bureaucracy deployed to infiltrate and gain strength - the forced distribution of paperwork to enforce and detect as well as the social control enabled by debt-could be rendered inoperative by ever more audacious incursions. The cumulative play of flight was one of withdrawal and tactical re-entry, a guerrilla without bloodshed.

Desertion was highly individualized and has therefore been said to have been a "conservative", "inhibiting" and fragmentary form of resistance or even as not a form of resistance at all. ${ }^{161}$ The tone of 'proletarian resistance' has no place in any shape or form. Even when faced with the same constellation of facts, where workers "fled so early in the term of recruitment that they had not yet worked off the advances", and indeed gave "false names to the recruitment agency in order to more easily cover their tracks once they fled into the wage labor market" this historical action was misread as resistance, says Eric Allina, mocking the image of workers who had been represented not "merely" as "actors" but as "nimbly planning ones who schemed to exploit their would-be exploiters." ${ }^{162}$ Clearly the tout-workers were not primarily 'victims' nor

\footnotetext{
${ }^{160}$ Jefe de Policía (Jaime) to AT San Carlos, 22 July 1960, AGA, C-81/09006, E-1.

${ }^{161}$ Harries; Work, Culture and Identity, 42; Atkins, The Moon Is Dead! Give Us Our Money!; Manchuelle, Willing Migrants; Dougnon, 'Migration for 'White Man's Work'.

${ }^{162}$ Allina, 'Resistance and the Social History of Africa', 192; see also chapter 4 and 7 of Allina, Slavery by Any Other Name.
} 
technically 'freedom fighters' but in practice, the crossing, staying, appropriating, experimenting and redeploying whatever was circulating in the confines of the colonial economy of Fernando Pó easily amounted to an outright anti-colonial stance of the most fundamental kind.

The dual spiral of the dash — escalating advances and fraudulent desertion — did not of course involve any syndicalist organization. On Fernando Pó collective "politics is a forbidden fruit"; "in that island of terrorism and brutality strikes are illegal and agitation is criminal." 163 "In this part of the world" says the resident British Consul "labour relations", meaning the industrial sociology of deliberated negotiations, "are unknown." Any "attempt to discuss or argue an issue with the employer would be regarded as an affront and the labourer may find himself in serious trouble."164 The surreptitious movement to and from contracts has often been downgraded to a technical search "for slight better wages", ${ }^{165}$ sustained by a "spontaneous and ephemeral" "communications network" strung along by touts in "a continuous, although unofficial, level of organization". The dual spiral of the dash-desertion and escalation of advances - cannot be mapped out from the codes of official payrolls, but only from the constant renegotiation of dash politics. While delineating the ways in which "migrant workers combined" Patrick Harries stops short of considering the touts and the advances and information they relayed as a radical self-organization. He does however vindicate the "transient and shadowy tramping system" as autonomous wielding by saying: "it was the very obscurity, ephemerality, and flexibility of this form of organization that was their greatest weapon." 166 A fight, where what was being sustained was a devastating critique of the colonial contract system itself.

\footnotetext{
${ }^{163}$ Lola Martins, 'Labourers Go Singing: Life with the Nigerians in Fernando Poo', Express, Lagos, February 22 1962; Peter Pan, ‘The Brutal Island', Daily Times, Lagos, 27 January 1965.

${ }^{164}$ British VC (Harriman), 22 April 1960, ‘Annual Report 1959/60’, TNA, FO 371/146562.

${ }^{165}$ Cooper, Decolonization and African Society, 45; Elias Mandala, Work and Control in a Peasant Economy: A History of the Lower Tchiri Valley in Malawi, 1859-1960 (Madison: University of Wisconsin Press, 1990); Jutta Bolt and Erik Green, 'Was the Wage Burden too heavy? Settler Farming, Profitability, and Wage Shares of Settler Agriculture in Nyasaland, C. 1900-60', The Journal of African History 56, 2 (2015): 217-38.
}

${ }^{166}$ Harries, Work, Culture and Identity, 40, 45. 
It was only outside or between contracts that reenganchos opened up the space for a form of contestation that first of all managed to get rid of the most abusive overseers and planters and then gutted the plantations at their very core-their declining rate of profit. The escalating dash was maintained by the self-organized working relationships between braceros, touts, prostitutes and smugglers. These groups did not only reside in a parallel "second economy" but navigated and configured the breakthroughs and contradictory interdependencies between "wage-earning and selfemployment". ${ }^{167}$ Drawing on the repertoire of dash negotiation techniques - selfevident demands, up-to-date scripts, masks made with forged papers-the reenganchos outwitted the imperial capitalist stamp that tried to engineer low-wages, and this, with an indispensable dose of confidence and dexterity; a remarkable manoeuvre.

\subsection{Conclusion}

The dash, with and without deserters, was well on its way to finish off the plantations for good - until "reforms" or the violent scenes of repression outside the doors of the Curaduria where the dash was being renegotiated and informally paid out, kicked in. The dash - and the touts who made the connections between the respective dash parties - emerged from this void of registration surrounding the Curaduria, from the thwarted ability of dirigiste political power to make reenganchos stand in an orderly queue behind unilaterally stipulated terms of payment. Such state co-ordinated contract monopsonies had been set up across imperial islands and enclaves of indenture in order to drive down and cap wages and worker bargaining power. ${ }^{168}$ As Keith Breckenridge shows, the elements of an "archival government" - contract templates, administrative stamps and sundry identification techniques-were only deployed in colonial economies in the first place to try to regulate the mushrooming of both wage advances and the related desertions that accompanied "capital intensive

\footnotetext{
${ }^{167}$ Janet MacGaffey, ed., The Real Economy of Zaire: The Contribution of Smuggling \& Other Unofficial Activities to National Wealth (Philadelphia: University of Pennsylvania Press, 1991), 12; Bolt, 'Waged Entrepreneurs, Policed Informality', 116.

${ }^{168}$ Arrighi, 'Labour Supplies in Historical Perspective' 200; Van Onselen, Chibaro, 21, 231; see also Levy, The Foundations of the South African Cheap Labour System.
} 
forms of labour recruitment". ${ }^{169}$ Commenting on the generalized system of "advancing wages", Major Orde-Browne recommended that "some written statement of any obligation of this nature should be drawn up at the time of incurring it"keeping tallies obviously helped when trying to sanction defaulters. ${ }^{170}$ Debts, after all, "must" be repaid. However, such binding properties did not emerge from the moral or quasi-magical invocations of sheer debt alone, but rather from the "organized violence" of those who measured and enforced repayment through labour. ${ }^{171}$ In postcolonial Latin America, like in colonial Africa, the advances of peonaje "usually involved indebtedness and always involved the machinery of state to make the system work". Laws tried to set limits on such advances, courts kept tallies of receipts and police sanctioned defaulters. ${ }^{172}$ This was the source of bondage in the labour relation, not the dash.

Even though bound by the "grotesque nuisance" $" 173$ of a chain of imperial contracts, passes and 'freedom papers', the reenganchos escalated the dash through an uncompromising commodity economics: the 'real value' of their labour as a type of 'free' labour, in the elementary sense of agreed wages and the ability to exit contracts. As Isaac Pepple, a Nigerian journalist arrested on the island in 1956, found out from "a group of five thieves [in the] prison cell": "strangely enough", the Nigerians who

\footnotetext{
${ }^{169}$ Breckenridge, 'Flesh Made Words', 88; Breckenridge, 'Power Without Knowledge', 22. For the direct line of sail between archival South Africa and the paperwork surrounding indentured labour in Mauritius and Bengal see Carter, Servants, Sirdars, and Settlers, 193-200; Singha, 'Settle, Mobilize, Verify', 163.
}

\begin{abstract}
${ }^{170}$ Orde-Browne, The African Labourer, 72. "The great majority of workers, when leaving home, wish to make various arrangements which entail small payments, and for this purpose they require an advance of wages. This then becomes an attraction in recruiting, and an agent who refuses to make any such concession will speedily find himself outdistanced by his more accommodating rival; further, a cut-throat competition may well set in when competing recruiters give increasing advances, until a point is reached where men are offered a large proportion of the whole of the pay due for the contract." See also Cooper, Decolonization and African Society, 60; Brown, “We Were All Slaves”, 83.
\end{abstract}

${ }^{171}$ Graeber, Debt, 121; Taussig, Shamanism, 65; Prakash, Bonded Histories, 242.

${ }^{172}$ Elizabeth Dore, 'Patriarchy from Above, Patriarchy from Below, Debt Peonage on Nicaraguan Coffee Estates, 1870-1930', in The Global Coffee Economy in Africa, Asia and Latin America, 1500 1989, ed. William G. Clarence-Smith and Steven Topik (Cambridge: Cambridge University Press, 2003), 209-35, 218; Sarah Washbrook, "Una esclavitud simulada": Debt Peonage in the State of Chiapas, Mexico, 1876-1911', The Journal of Peasant Studies 33, 3 (2006): 367-412, 390.

${ }^{173}$ Breckenridge, 'Flesh Made Words', 88. 
had "smuggled themselves" onto the island, did so "because as free men, they can bargain for high wages" - in the form of a dash. ${ }^{174}$ Needless to say, the autonomous escalations of the dash took place entirely besides imperial self-definitions of 'free' contract labour, and indeed wholly outside liberal notions of the self-regulating market. The element of "freedom" in the dash had nothing to do with fixed wages for a set period, but with inserting an own criterion into the parameters of exchange. Across the boundaries of imperial states as well as those of the cellular plantation patios, an alliance of workers, touts, prostitutes and smugglers opened borders and doors where these had been closed.

Even though the spiralling coup of the dash was a provisional and rare feat, the selfpropelled trajectory of the reenganchos on Fernando Pó was sustained by a praxis based on a sense of fairness - a moral economy of radicalized economics - in one of the most structurally violent colonies of its day. Dash-peonage had a deeply ambivalent and highly volatile trajectory that straddled and circumvented the free/unfree labour binary and the colonial economy itself. For braceros the dash was a promising, even a just moment that could be pulled out from inside a colonial stateimposed device for calculating bondage, a rare leverage around the wholly predetermined terms of contract. With it, they ignited an unpredictable series of events. Employers attempted to deploy the dash as a bind to keep experienced labour power, but the ploy of the dash clearly got way out of hand. The gifty code of the dash came back to haunt the planters by providing the braceros with the tool-a peaceful one rooted in the creative capacities of language and renegotiations - to arm themselves on the island.

\footnotetext{
${ }^{174}$ Isaac Pepple, 'Free Ticket to Hell,' Drum, Lagos, April 1957.
} 


\section{It's Time to Talk about the Contract}

The 'labour question' in slave colonies was straightforward, buy people from people who sell them. How was this question answered after emancipation? 'Recruit them'; recruitment, pay recruiters to bring them or pay workers in advance to come and stay. Recruit, recruiting, recruitment, are terms most consistently found and applied in military circles. The root for the word recruit stems from the sixteenth French word recrue which in a solely military context meant "a supply" or "a levy of troops"; the literal French meaning is "new growth" or to "grow again", to enlist new soldiers or supply military reinforcement to the front line. Where the army is weak, depleted and outnumbered and where there is no state-organised conscription, the military dispatched recruiters who always seemed able to target and find groups of overzealous and fantastical minded people as well as the very vulnerable, poor and young. How to get people to a place where they do not necessarily want to be? Recruitment channels needed to be held in place by something else. Recruitment splits from other forms of unfree labour which are bound and dependent within the categories of one place, involving a range of customary collective categories such as castes or serfs. Yet a type of social ordering in place, usually hierarchical and violent was indispensable for recruiters to forge their channels. They required the existence of a customary legal status of unfree labour: the colonial contract.

In Havana, Cuba, already in the mid-nineteenth century commissions were being set up by colonial authorities who were now facing a large number of mostly self-manumitted "negros libres" or "free blacks". The first questions they asked was: "What regulations can we impose to establish el trabajo obligatorio para los negros libres." Trabajo obligatorio for the libres; forced labour of free people that was the labour question posed in the colonial plantations of the Spanish Empire. ${ }^{1}$ In 1847 , commenting on the

\footnotetext{
${ }^{1}$ Spain and Junta Informativa de Ultramar, Interrogatorio sobre la manera de reglamentar el trabajo de la poblacion de color y asiática y los medios de facilitar la inmigracion que sea mas conveniente en las provincias de Cuba y Puerto-Rico (Madrid: Imprenta Nacional, 1866), see also Imilcy Balboa Navarro, 'Libertos, vagos y bandoleros: La reglamentación del trabajo tras la abolición de la esclavitud (Cuba 1886-1895)', Relaciones 32, 127 (2011): 87-116. Post-abolition Brazil is similar filled with the "falta de braços" line, though here it was overcoded with an racial imaginary of tring to whiten the country with European labour, Lamounier, 'The "Labour Question" in Nineteenth Century Brazil'; Celia Maria
} 
abolition of slavery in the British Caribbean and the "invention of a system to force the blacks to work under contracts for a certain period of time", the Spanish minister responsible for the colonies wrote to the Capitan General in Cuba to say that these "partial contracts" of tutela or apprenticeships and indentures were "a system that does not improve the condition of the slave, but the English Government has accepted it under the banner of 'free labour', and is using it as a medium to save the [plantation] colonies that are now under threat." 2 The Spanish colonial authorities soon followed in their ideological steps and missteps.

In this chapter I add empirical and combine conceptual material so that these steps and missteps may be put to rest - the colonial indentured contract had nothing to with free labour, even if voluntarily entered into. Indentured contracts are sometimes taken to signal a clear step to "liberty", principally because of the formalities of "consent" and the existence of the "wage" for a specified period of hire. ${ }^{3}$ But consent loses its meaning in situations of obligatory contracts. ${ }^{4}$ Contracts were a relationship of "master and servant"; as John Locke said, all the contract did was to stipulate the expectation of

Marinho de Azevedo, Onda negra, medo branco: o negro no imaginário das elites, século XIX (Rio de Janeiro: Paz e Terra, 1987), 97.

${ }^{2}$ Departamento de Estado, Madrid to Capitan General de la Isla de Cuba, Havana, 25 October 1847, 'Expediente sobre la resolución de Inglaterra de emplear en Jamaica negros libres de África, debido a la falta de mano de obra agrícola por la abolición de la esclavitud, y la posibilidad de aplicar el mismo sistema en Cuba', BNE, Biblioteca del Ministerio de Ultramar, Signatura: 296-1-2. Lucena Salmoral, Los códigos negros de la América española. In 1860 "the plantation economy had reached its maximum peak" with plantations of up to 11,000 hectares which could hold "866 slaves and produce 2670 tonnes of sugar annually". See also Franklin W. Knight, Slave Society in Cuba during the Nineteenth Century (Madison: University of Wisconsin Press, 1970), 10-1; Scott, Slave Emancipation in Cuba, 87; Tomich, Through the Prism of Slavery, 82.

${ }^{3}$ Emmer and Boogaart, 'Colonialism and Migration'; Edgar Graham, Ingrid Floering, and D. K Fieldhouse, The Modern Plantation in the Third World (New York: St. Martin's Press, 1984). In postemancipation contract labour there was always a baseline regulated wage, but as historians of slavery have pointed out, this amount was strictly "a symbol of exchange and thus of voluntarism even in a situation of nearly absolute subordination." For abolitionists it was not the slaves "subordination or lack of mobility that ran contrary to nature. It was rather the lack of any token of exchange which would make the worker responsible, at least theoretically, for [their] own destiny." David Brion Davis, The Problem of Slavery in the Age of Revolution, 1770-1823 (Ithaca: Cornell University Press, 1975), 492; Seymour Drescher, From Slavery to Freedom: Comparative Studies in the Rise and Fall of Atlantic Slavery (New York: New York University Press, 1999), 399-443.

${ }^{4}$ See Steinfeld Coercion, Contract and Free Labor, 15-6; Trebilcock, The Limit of Freedom of Contract, $78-81$. 
"limited Power on the one side, and obedience on the other". 5 Indeed the minor orthodoxy amongst critical legal and feminist historians is clearly that there are "problems with contract." Whether "classical or neo-classical models are employed" these are "unable to sustain the baggage of rhetoric that constructs it as emblematic of freedom". ${ }^{6}$ This insight had been established by earlier generations of labour historians, who, faced with systematic treachery in colonial contract labour, happily rid themselves of the notion of consent. As Jan Breman said long ago: it is "nothing other than a colonial fantasy to maintain that a contract was entered into voluntarily."7 Traditionally registered and legible along a moment of signing, the notion that this was the primary ingredient of 'free' or contract labour has historically proven to be a moot point. In Fernando Pó as elsewhere employers and the colonial state did not actually seem to screen workers who entered their contracts for a discrete moment of consciousness unencumbered by the world in order to draw a "boundary between compulsion and free will". This divide as elsewhere, also in fascist Europe, was "neither distinct nor of any great interest". 8

The contract that braceros signed was between two to five years long - this time-frame was practically irrevocable and set in juridical stone between 1862 and 1968. Breaking or cutting-short one of these contracts was close to impossible, except through desertion. As Peter Enahoro said with a dose of earnestness: "It is easier to divorce a catholic than to break a contract on Fernando Poo." 9 Those working under the same contract on the island could be kidnapped labourers brought on canoes, prisoners or tributary subjects of conquest, or they could be indentured through international labour

${ }^{5}$ Locke, Two Treatises of Government, 158; also Amy Dru Stanley, From Bondage to Contract: Wage Labor, Marriage, and the Market in the Age of Slave Emancipation (Cambridge: Cambridge University Press, 1998), 6-7.

${ }^{6}$ Catherine Alexander, 'Legal and Binding: Time, Change and Long-Term Transactions', Journal of the Royal Anthropological Institute 7, 3 (2001): 467-85, 477, 479; see especially Patrick Atiyah, The Rise and Fall of Freedom of Contract (Oxford: Oxford University Press, 1979); Victoria Kahn, Wayward Contracts: The Crisis of Political Obligation in England, 1640-1674 (Princeton: Princeton University Press, 2009).

${ }^{7}$ Breman, Taming the Coolie Beast, 132.

${ }^{8}$ Ulrich Herbert, Hitler's Foreign Workers: Enforced Foreign Labor in Germany Under the Third Reich (Cambridge: Cambridge University Press, 1997), 59, also Banaji, 'The Fictions of Free Labour', 79.

9Peter Pan, 'Spanish' is a Synonym for Savages', Sunday Times, Lagos, 4 March 1962. 
treaties, or they could be resident immigrants on the island with three contracts of service under their belts. In some obvious sense, consenting beings were the opposite of kidnapped and extorted ones. The type of contracts that operated on Fernando Pó can only be understood as their own form of bondage, with its own distinctive parameters and temporalities. The contract was a device to strip people who were previously considered to be free and legally reconstitute them in bondage. ${ }^{10}$ It was a paradoxical passage as, unlike hereditary or chattel slavery it also promised a release.

A Gobernador of Fernando Pó, who previously held an administrative post in Cuba, was "reminded of the Cuban planters" who "screeched and screamed into the heavens, arguing that the abolition of slavery will paralyze and cause total ruin of the island."11 After the abolition of slavery in Cuba in the 1880s, as Rebecca Scott notes, "planters seeking subsidized immigration or laws restricting workers' rights tended to speak in terms of a "scarcity' of workers." 12 She may have added that they also sought out and generated a new class of intermediary agents to constantly bring in new recruits. As the planters on Fernando Pó - many of whom had arrived from Cuba after the war of independence in the $1890 \mathrm{~s}$ - were well aware, by the early twentieth century "Cuban planters [were] employing many thousands of blacks during the sugar harvest; they are free to recruit indigenas wherever they find them, inside or outside their territory. They fork out wages and commissions at whatever price can be negotiated", either to recruiters or to workers themselves. ${ }^{13}$ The planters on Fernando Pó looked over to

\footnotetext{
${ }^{10}$ The indentured contract was an encompassing legal exercise. In an earlier related iteration of Chinese coolies in Cuba it was expressly totalizing: "it is understood that the workers who sign or accept their contracts renounce their ability to exercise all civil rights which are not compatible with the fulfilment of their obligations they thereby incur." Cuba, Reglamento para la introducción de los trabajadores chinos de la Isla de Cuba (Havana: Imp. del Gobierno y Capitanía General, 1860), Article 34.
}

${ }^{11}$ Ramos-Izquierdo and Navarro, Descripción geográfica, 262.

${ }^{12}$ Scott, Slave Emancipation in Cuba, 239.

${ }^{13}$ DGMC (Jordana) to GG (Núñez de Prado), 19 September 1927, AGA, C-81/06415, E-13. The smuggling of undocumented labour into Cuba was common in the early 1900s, including of braceros from Korea and Japan via other Central American territories. The American United Fruit Company in 1913 "was granted the first-ever government permit given to any private company operating in Cuba to bring a large contingent of braceros" from "neighbouring islands". Soon "another law was signed that authorized private parties to introduce braceros, although certain restrictions were imposed and the government reserved the right to repatriate them when necessary." On more official terms, the Cuban planters had managed to bring 40,000 "Haitian braceros" annually to the Oriente or the eastern province of Cuba between 1913 and the early 1930s. Margarita Cervantes-Rodriguez, International Migration in Cuba: Accumulation, Imperial Designs, and Transnational Social Fields (University Park: Pennsylvania State University Press, 2011), 127, 128; Oscar Z. Lecuona, 'La United Fruit Company en Cuba: 
Cuba's flexible oscillation between recruitment systems and generated in the Gulf of Guinea a kind of new Caribbean presence.

The imperial state was not monolithic or impervious, but it was also not "thin". ${ }^{14}$ Fernando Po was a small place; behind it lay the technical and emotional investments of the nostalgic Spanish armed forces-who organized its colonization and administered its daily affairs until the very end. The power of the imperial state can be felt and approached in various ways. Formally it is axiomatic and self-constituting, practically it is haphazard and experimental, but through both the domains of the abstract and the concrete, the state founded and sustained the recruitment economy through one thread: the contract. A simple piece of paper. The contract was not a blueprint or a design, but the result of borrowing and compromises, a mix of copy and pasting other legislations and a mass printing that sedimented into a local custom. Planters in Fernando Pó could not make labourers step down from their assorted sets of grid paper into which they monthly jotted down their required and desired number of braceros per hectare. They had to enlist a mostly 'peaceful' army of touts. Touts could only turn recruiters if they, in the final instance, appeared through channels structured by the destination, the "contract, legal and binding; it is an artefact of action and connection." 15 Yet touts were not despots - they were categorically not the agents of violence or, even less, of "law". A despot can always afford to operate without negotiation and can also call in militarized back up. If a tout tried to be a despot, they would have been quickly avoided or assassinated.

Braceros all fell under the same contract, but they could come into it through a variety of recruiting assemblages, between touts and despots, between those who produced debt bondage through the wage advances enabled by long-term contracts and those who submitted people into pre-defined terms of temporary servitude. With touts, recruitment

Organización del trabajo y resistencia sbrera', Clío América 2, 4 (2008): 238-58, 246; They also recruited Spaniard from the Canaries. Spanish braceros see Francisco J. Macías Martín, Cuba: Crisis politica, crisis económica y emigración (1920-1935) (Tegueste: Ediciones de Baile del Sol, 2002). For the switch to rising dependency on precarious Carribean labour where people could be deported at will, see Philip A. Howard, Black Labor, White Sugar: Caribbean Braceros and Their Struggle for Power in the Cuban Sugar Industry (Baton Rouge: Louisiana State University Press, 2015), 21-61.

\footnotetext{
${ }^{14}$ Cooper, Colonialism in Question, 182.

${ }^{15}$ Alexander, 'Legal and Binding', 482.
} 
rotated with speed and secrecy around commercial propaganda and hands-on improvisation. Its principal characteristics were deception and an open-ended deluge of promises of wage-advances. In despotic assemblages the way into contracts was transparently declared and premised on a painfully slow instance of staged contractual 'consent' that could be imposed or opted into without an excess of language or debtmoney. Indeed, austere is what it aimed for, the lowest possible wage and only the most economical communication enshrined in a despotic stamp - in Fernando Pó it was: 'No?! Think again'—or in Nigeria it was an affidavit_-'Yes? Nod, thumbs up, sign'.

For the first two-thirds of the twentieth century, Fernando Pó was trying to eagerly latch onto state-led exporting facilities for indentured labour. The colonial office in Madrid, Spanish embassies the world over, and well-connected friends of the Cámara initiated failed indentured labour treaties intended to bring indentured labour from India (1928, 1947), China (1896 via Cuba, 1928), Indonesia, Malaysia and the Philippines (1928), Morocco (1929-1930), Romania (1929), São Tomé (1929, 1931), Cameroon (1934-1936), Congo (1945), Cape Verde (1951), Upper Volta (1962), E1 Salvador (1958), Haiti (1934, 1949, 1959), from Liberia again (1949), and persistently Mozambique (1927, 1933, 1952) and Angola (1930, 1939, 1945, 1952). "Oh the long list of hopes and the aborted plans: Romanian workers, Muslim braceros, and even Chinese coolies!" 16 The archive is filled with these un-histories of a standardized global indentured labour market. Most of these far-fetched plans were false starts, while others crumbled after a first batch was sent (China, Morocco) or after being signed (Cameroon). Treaties had offered glimmering but always thwarted hopes for "the agriculture on the island, as [free] recruitment costs made up the highest share of expenditure" for planters. The costs of la recluta libre "would be almost eliminated

\footnotetext{
${ }^{16}$ Llompart Aulet, Legislación del trabajo, 12. This was amply commented upon by impressed British colonial officials going over the range of fanciful "schemes [that] were mooted, for example, for obtaining labour from places as remote from the Gulf of Guinea as Rumania and Canton. Chinese labour was in fact brought to the island, but the scheme was a failure and those who had been brought had to be repatriated." Nigerian Secretariat, Lagos, [undated, 1953] 'Memorandum', RHL, 600.18 s. 21/XI (10); 'Los Braceros Chinos', España Colonial, Santa Isabel, 1 February 1929. Well into the 1960s, when Spanish Guinea was desperate to disentangle itself from their complete dependency on Nigeria, the diplomats continued to pursue indentured labour treaties throughout vulnerable parts of the world under dictatorial rule such as Haiti and El Salvador, asking for at least 10,000 workers on five-year contracts. See AMAE, R887, E-52; R3215, E-56; AGA, C-81/08095; C-81/08147; C-81/12373; and LinigerGoumaz, 'La cuestión bracera', 497-534.
} 
[through a labour treaty] and so we will have finally resolved the problema de brazos." 17

Before the British allowed licensed recruiters to operate out of Calabar in 1943, they had for decades been rejecting repeated requests by the Spanish for a formalized indentured labour treaty. The top diplomat of the British Colonial Office, with a very Colonial Office name, Cecile Bottomley, recommended to a Spanish counterpart to "encourage [the] natives to work on their account, that is to say outside a regime of contract or servitude." 18 A Francoist Gobernador shared a cognate thought to a close confidant: "the problema is kind of our fault for we chose the system of colonization based on propertied Europeans. I always thought that Europeans should be the intermediaries and the indigenas the producers, but oh well, what's done is done and now we have to deal with it."19

Spain's and the planters' mostly failed negotiations peaked long after these sorts of arrangements were unanimously in decline - indeed the literature orientated around Asia and the Caribbean uses the British threshold of the early 1910s to declare indentured labour dead and buried. In broad framings of colonial indenture, some historians have insisted on definitions that involve "inter-continental" long-distances organized as wholesale passages by colonial states- "indenture at the point of departure". ${ }^{20}$ This seems not right, since a migrant that signs on nearby or in situ to an indentured contract is still indentured, no matter how or when they arrived. Divides

${ }^{17} \mathrm{GG}$ (Lluesma) to DGMC (Alvarez-Buylla), 18 September 1933, AGA, C-81/06867, E-5.

${ }^{18}$ Embajador de España (Barcenas), London to DGMC, 25 June 1930, AMAE, R887, E-52. A few republican reformers agreed with the characteristic British line of fearing an African proletariat: "We should guarantee the future with the existence of an indigenous capitalism, which a part from being more productive, staves off the dangers of full immersion in our civilization, which is to convert the totality of the indigenas into salaried workers". Arizcun and Martínez, 'Memoria sobre los territorios españoles del Golfo de Guinea', 126, BNE, AFR/13541.

${ }^{19} \mathrm{GG}$ (Suances) to SubGG (Cabrera), 1 October 1939, AGA, C-81/08195, E-2.

${ }^{20}$ Northrup, 'Free and Unfree Labor Migration, 1600-1900'; For this definition that falls back on an arbitrary and one-dimensional measuring stick-let's say over 4000 kilometres — see Northrup, Indentured Labor in the Age of Imperialism, 13; "Indeed, overseas indenture was written into the very definition of emigration in the Emigration Act of 1888, which defined emigration as 'Departure by sea out of British India of a Native of India under an agreement to labour for hire in some country beyond the limits of India other than the island of Ceylon or the Straits Settlements." And even then "indentured labour contracts" were principally thought of as those "with European employers". McKeown, Melancholy Order, 76, 49. 
cannot be made; what is significant and effective is the contract itself and the specific recruiting relations that it could found and prefigure.

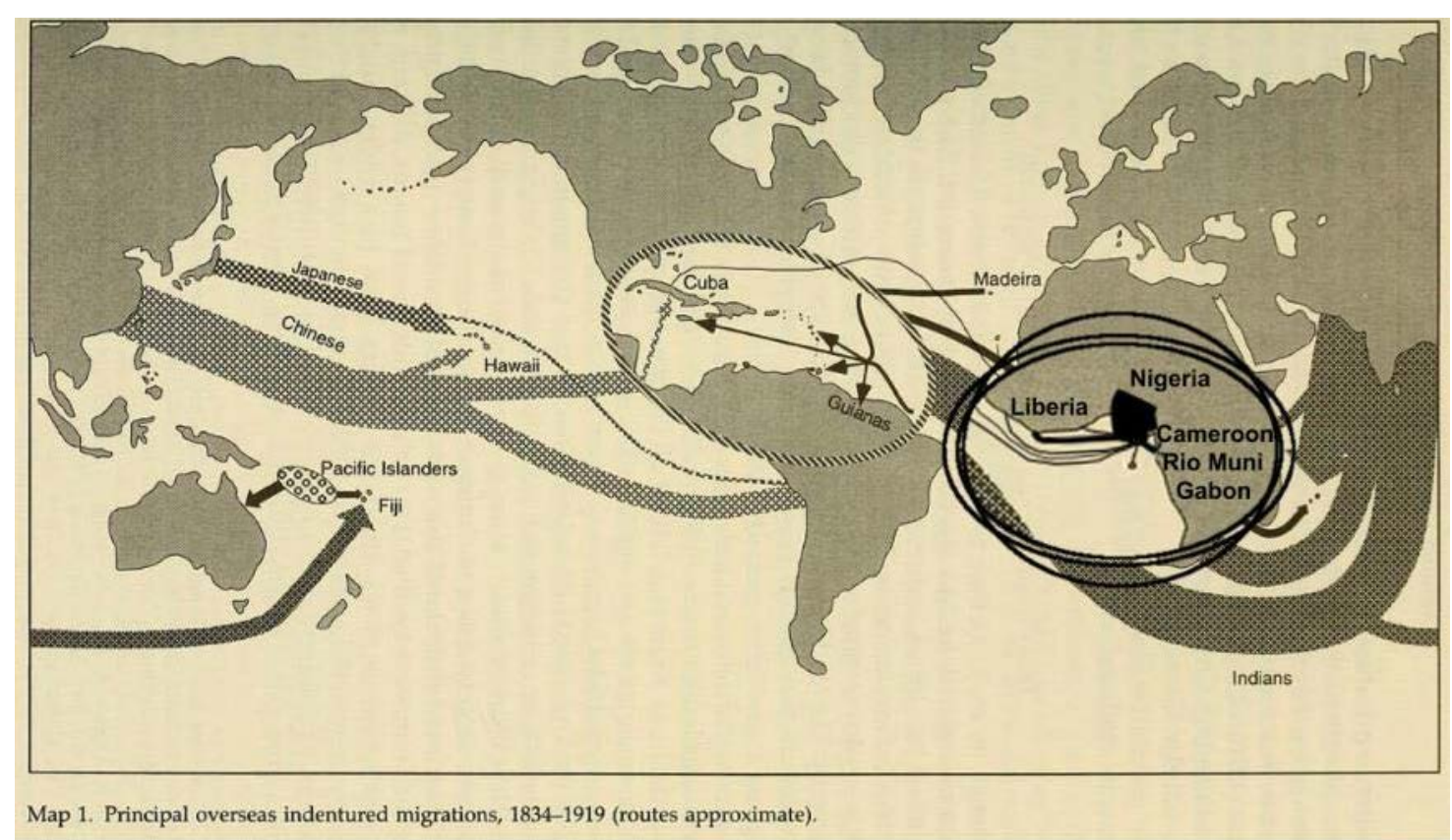

Map 7 An own addendum-'Gulf of Guinea 1867-1975'—to Northrup's map ${ }^{21}$

As Prabhu Mohapatra says "even in the absence of (and after the abolition of) a formal indenture system" in the British Empire, indenture "acted as a template for the 'contract' and debt-bonded migration of free labourers" that followed the more formalized colonial "export" of emigrants. ${ }^{22} \mathrm{New}$ forms of violent subjection and recruitment based on kidnapping were also largely poured into the mould of indenture. All these varied innovations in the wake of imperial indenture continued in Fernando Pó, but the contract on the island was still mostly of a "classic" type. In any case what mattered most was a series of localized "Masters and Servants Acts, [without which] indenture would have been impossible." 23 On Fernando Pó it was not only that there

${ }^{21}$ Routes and width approximate. Adapted from Northrup, Indentured Labour, 12. Northrup's map "Principal overseas indentured migrations, 1834-1919" left West Africa blank except for the Kru who went to the Caribbean in the 1840 s and 1850 s.

${ }^{22}$ Mohapatra, 'Eurocentrism, Forced Labour, and Global Migration', 111.

${ }^{23}$ Stanziani, 'Beyond Colonialism', 71; The best analysis of penal sanctions in labour history is by Prabhu Mohapatra who says that these were "not in any way in contradiction to the reigning contractarian ideology of free labour, in fact it was explicitly based on it." A "labour relations under this legal regime was hived off into 'criminal jurisdiction'. A breach of contract was thus not a civil matter between private individuals but a crime against the 'state' and the body politic. It was thus that at the 
were types of Master \& Servants like penal sanctions for the breaking of contractthese were in full force until independence in 1968 - but that 'transgression' and prison was a default. Arriving on the island without appropriate paperwork was a punishable offence in the first place. The vast majority of those who immigrated or were smuggled onto the island understood the contract as a regime of "temporary paid servitude", where the "only choices on offer", as for the coolies in nineteenth century Cuba, were either "perpetual servitude or expulsion" after the expiration of a contract. ${ }^{24}$

There were a myriad of different contracts regulating different employment relations and statuses, but what matters is the route into these contracts and how these routes were made possible by the contracts themselves. The contracts were how relations of recruitment were knotted together, even though the first steps were initiated in far flung corners, circulations always passed through them; both panyarring and the dash were extrapolated and premised on its stamp. The messy character of recruitmentrecursive, embedded, inflected - is part of the history of the prefigurations and consequences of imperial formats. The imperial contract cannot be meaningfully studied as a formal procedure and a statement of consent and conditions in its own "emic" terms - otherwise historiography lapses into old habits of writing out the legislative small-print and ratifying the liberal ideological projections that the term "contract" seems to stubbornly entail.

\section{$5.1 \quad$ Contracts}

Functionaries, managers, overseers and braceros all had a contract, of different types. Contracts were obligatory, a constant feature of the "custom of the country", as the early bondage contracts in colonial Americas which indentured recruits signed onto

heart of liberal ideology of private contract and laissez faire lay the invocation to the State power." Mohapatra, 'From Contract to Status?', 120.

${ }^{24}$ Walton Look Lai, 'Asian Contract and Free Migrations to the Americas', in Coerced and Free Migration: Global Perspectives, ed. David Eltis (Stanford: Stanford University Press, 2002), 229-57, 246; Chris Evans, "Carabalí" and "Culíes" at El Cobre: African Slaves and Chinese Indentured Labourers in the Service of Swansea Copper' (World of Copper: Globalizing the Industrial Revolution c.1830-1870, Burra, Australia, 2012), 12. 
were called. ${ }^{25}$ The bracero contracts were called that, contracts, but they were of course not some sort of deliberated civic agreements of mutual accord, a 'meeting of the minds', a will electing roles and obligations; rather, contracts were a material force, creating a motion around an 'object' through a pull. ${ }^{26}$ The indentured contract on Fernando Pó objectified the very person it generated, it allotted the bracero a place within a sub-genre of a reigning contractual order, a 'type of contract called 'bracero' to which all who are braceros are subject." 27 On Fernando Pó employers kept the original contract. All paperwork, except the very hesitantly granted "passes" or temporary permits needed to lodge complaints or visit the hospital in Santa Isabel, were kept under lock and key by employers-including "the personal copies of workers contracts"; for "safe-keeping". ${ }^{28}$ This original copy of the contract was a "living document", "for the indigena, the contract is a document vivo" wherein "all incidents

${ }^{25}$ John Donoghue, 'Indentured Servitude in the 17th Century English Atlantic: A Brief Survey of the Literature', History Compass 11, 10 (2013): 893-902, 893.

\begin{abstract}
${ }^{26}$ Property arrangements created "not by virtue of the relation of an object to my subjective will, but by virtue of another will, and share in a common will, is contract"." He saw all the usual absolutes in the contract: "it is reason, or the idea as it is embodied in the realized will of a free person" that "really" "occasions the contract". Hegel took a lot for granted: "It is taken for granted that contracting parties recognize one another as persons and owners." Hegel, Philosophy of Right, 23. Weber called this a "voluntary agreement constituting the foundation of claims and obligations", and the basis for "enabling law," as opposed to coercive law, Economy and Society, 671. This type of contract theory, only held sway in minor intellectual circles between 1770 and 1870, where it was assumed that two parties with equal bargaining power could freely choose to impose mutual obligations upon themselves in order to carry out a transaction through time. Atiyah, The Rise and Fall of Freedom of Contract; Herzog, Happy Slaves, 161-3. As the jurist Friedrich Kessler already reasoned in the inter-war period: when all employers "use the same clauses" or deploy contracts under a "monopoly"-always "artificial" and taking place under "sovereignty", then the contract becomes by definition "but a subjection more or less voluntary to terms dictated by the stronger part." Friedrich Kessler, 'Contracts of Adhesion: Some Thoughts About Freedom of Contract', Columbia Law Review 43 (1943): 629-42, 632; also Banaji, 'The Fictions of Free Labour', 77.
\end{abstract}

${ }^{27}$ Curaduría (Carrillo) to GG (Núñez de Prado), 9 December 1926, 'Asunto: Recontratacion (reengancho)', AGA, C-81/07720, E-1. This is what indentured meant, being turned into a mix of a servant and an employee, through an elaborate conversion, not a worker working but a category of a working person, a bracero, "whose 'indenture' contracts subordinated them under their employer" for the "whole duration of their contract". Ahuja, 'Networks of Subordination', 16. Best, 'Outlines of a Model of Pure Plantation Economy', 287, calls this a "total economic institutions" that "encompass the entire existence of the work force." The bracero contract was what Weber, Economy and Society, 672, would call variously a "political", a "feudal", or a "status contract" that "temporarily or permanently" changes a person's "total legal situation (the universal position) and the social status of the person involved."

${ }^{28}$ British VC (Spencer-Cooke) to Commissioner of Labour, Lagos, 8 January 1950, 'Annual Report: Fernando Poo 1950', TNA, CO 554/169/2. 
and relations with his employers are inscribed, whether it be for contracting debts", or "for annotating the loss of labour days due to sickness, desertion and permission, etc." 29

A "copy of the contract" was put into "the hands of the carrier", "free of charge" in order to "serve as the document supporting the 'identity' for all procedures that need this effect." Losing or hiding the paper-copy of the contract would translate into a 100 peseta fine or about three months' wages. ${ }^{30}$ This inscription of identity took place immediately after the "signing of the contract, in front of the Curador Colonial, who adds any identifying markers and prepares the fingerprints." ${ }^{31}$ In a situation where " $95 \%$ of the workers do not of course know how to sign their own name", fingerprints inscribed on all contracts and were thought of as the mark of consent. ${ }^{32}$ The ceremonial and communicative aspect of the signing was confounded by the fact that "at the Curaduria there [was] an interpreter who elaborates and explains the reach of the contract, the language used for this interaction [was] very limited, formulated in the a mix Portuguese, English and Spanish and words in the dialect of the Krumanes" or Pidgin. ${ }^{33}$ The contrato was simply a fiche to keep track of wages and fines. The bulk of the contract contained empty columns for calculating and summing up these numbers. It was followed by an appendix with the entirety of the labour code printed in miniscule. While this code was essentially a compendium to pre-empt or disable resistance and every precisely detailed sanction contained the residue of past collective

\footnotetext{
${ }^{29}$ Llompart Aulet, Anuario estadistico 1942-1945, 192. The live document was like the machine the Harrow in Kafka's story of the penal colony, that etched "whatever commandment the prisoner has disobeyed" into the skin of the prisoner. Kafka's unfortunate protagonist "will have written on his body: HONOR THY SUPERIORS”. Clastres, Society against the State, 177; Kafka, The Penal Colony. In 1936 the Labour Officer took a look at the booklet of one labourer who had "been detained for 138 days in addition to being fugado for 58 days." His sister petitioned the Governor announcing that his employer "ordered the detention of Apolonio, alleging that he abandoned his place of work". The Labour Officer took a look at his "contract booklet that is full annotated punishments" and concluded that the labourer "has fugado several times. He is wayward and rebellious towards the powers that be, the ones who give orders." He was kept in jail: 'Honor thy superiors', 'fulfileth your obligations.' Josefa Ntolo to GG (Serrano), 17 November 1936, AGA, C-81/08153; Curaduría (Guixeres) to GG (Serrano), 24 November 1936, AGA, C-81/08153.

${ }^{30}$ Curaduría (Carrillo) to Farley Smith, n.d. [1940], AGA, C-81/08131, E-3.

${ }^{31}$ DGMC (Jordana), 1928, 'Trabajo en las colonias españolas', AMAE, R887, E-52.

${ }^{32}$ Peter Pan, “'Spanish’ is a Synonym for Savages', Sunday Times, Lagos, 4 March 1962.

${ }^{33}$ DGMC (Jordana), 1928, 'Trabajo en las Colonias españolas', AMAE, R887, E-52. For this fauxtranslator to be present, the Spanish until the 1940s even charged a small fee, that they deducted from the wages of the bracero.
} 
contestation, the contrato, a result of struggle, was however a non-negotiated device, perpetually imposed and prescribed from above. ${ }^{34}$

Planters furiously maintained and refused to reassess the form and length of the contract. ${ }^{35}$ By the 1930s the Cámara thought of the two-year minimum as a "tradition"; "it has always been this way on the island." "Shorter-term contracts" would be "detrimental rather than favourable, well after six months el problema would rear its head again". In earnest antipathy to the types of bureaucracy which could have underpinned less attached labour, the Cámara, always lamented that "a short-term contract" would be absorbed by formalities, that they would "lose" the labour time of "their braceros" to "all the time-consuming tasks, like registration, medical check-ups, etc." 36 Though the favourite rhetorical justification of planters was to start form the inverted logic of the premise of recruitment costs: only "long contract" could offset the "repayment of the onerous initial expenses" represented by the recruiters' commission and the dash. ${ }^{37}$

\subsection{Labour Office}

The Spanish made contracts obligatory in their first labour code, the 1906 Reglamento de trabajo indigena. The code made "unemployment" illegal by declaring an "obligation to labour either for the state or for private parties". Article one was straight

\footnotetext{
${ }^{34}$ This part of the contract stipulated the conditions and "perfectly defined rations, housing conditions, hours of work", thought of as the concrete "obligations that an employer has to his braceros". In theory this provided the legal terrain for contestation and setting the bar for what would be codified as insufficient, excessive or abusive, but it also contained "obligations that the latter has with the employer", defined principally on a temporal axis of duration, and a command to follow any and all work orders for that time-span and remain in place, except for Sundays. These obligations could only be rendered null if a workers was expelled for being "useless" or "dangerous" or an employer had engaged in "cruel abuse". Ramos-Izquierdo and Navarro, Descripción geográfica, 263. ${ }^{35}$ As the delegated recruiting agent in Rio Muni of the Cámara, a former Captain of the Colonial Guard,
Julián Ayala says-without forgetting to explain the key reason why his commissions were so high: "the
problema is difficult and needs to be tackled head on and defeated. I think we should be looking at it
from a different angle, not about the \# of braceros we consign to you, but that these come for 3 years and
if longer, then better. 1000 men for three years are preferable and gives superior results than 2000 for two
years." Julián Ayala to Cámara, 26 March 1929, AGA, C-81/06418.

${ }^{36}$ Cámara to GG (Fontán), 13 April 1938, ‘BRACEROS', AGA, C-81/08126, E-1.

${ }^{37}$ Union de Agricultores de la Guinea Española (Rodriguez Barrera), Barcelona, to DGMC (Canovas), 9 October 1931, AGA, C-81/08095, L-2, E-21.
} 
out of the box: "Foment civilization and thrust the indigenas to work". The "wording used was impulsar", to propel or thrust, "a word which tend spontaneously and irresistibly to action", says Juan Bravo, the leading colonial ideologue; yes it does. ${ }^{38}$ They chose this wording so that the uniquely colonial institution, the Curaduria Colonial - thought of as tutelary body mediating all forced and voluntary contractscould immediately shovel the indigenous Bubis of the island into contracts. ${ }^{39}$ In these state-decreed contracts there was obviously a "total lack of contractual rules [which] turned the Military Authority into the immediate addressee of such provisions." These decrees did "not deal with the issues of harvesting, contracts, and farms and simply turned [the] shortage of labour in Guinea into a purely military matter." 40

In "Africa" says an excited Spanish settler "it so happens that the African does not or does not feel the need to work for us. A whole new philosophy and morality and even law must be demarcated. Before proclaiming his right to freedom, the African proclaims his right to laziness. European governments who want to realize public works and the colonial companies who are trying to turn the virgin forest and the miasmas of malaria into plantations of cotton, rubber and rice are confronted with the problema de mano de obra which contains that anxious dilemma, whose choice is either violence or ruin. Let it be violence!"41 The ensuing imperial assault was mildly indirect, orchestrated through the skirmish of contracts backed by the state. The violence of the state was not principally whimsical, a series of racist attacks, it was a

\footnotetext{
${ }^{38}$ Juan Bravo Carbonell, 'De la Guinea Española: El trabajo indígena', El Sol, Barcelona, 3 June 1930.

${ }^{39}$ España, 'Reglamento del Trabajo Indígena', Article 1, Article 24. The Reglamento de Trabajo Indígena was constantly added to with variety of gubernatorial decrees or instrucciones, ordenes, directly instructing and ordering corvée or prestación for the cacao plantations. The Gobernador Luis Ramos Izquierdo insisted that the Bubi "should acquire the habit of disciplined labour [so] I made them work during the harvest of 1907 and 1908." Ramos-Izquierdo and Navarro, Descripción geográfica, 257. The next Gobernador decreed forced contract labour in a slightly indirect way, "all the Bubis of Fernando Po not possessing $1 \mathrm{~h}$ of land were compelled to enter into a temporary contracts" or face unpaid prestación. "This provision was harshly enforced, for in 1910 the Bubis of Balacha revolted." British VC (Michie), 28 February 1941, 'Labour Conditions in Spanish Guinea', TNA, FO 371/26908.
}

${ }^{40}$ Petit, 'The Colonial Model of the Rule of Law in Africa', 468, 470; Campos Serrano, De colonia a Estado, 59-61.

${ }^{41}$ Dionisio Perez, 'España acusada de esclavismo?', La Voz Galicia, 26 January 1930. 
subjection wedded to a "quest for productivity", violence as a matter of axiom and, in the last instance, sustained and fed through violent intentions and designs. ${ }^{42}$

"These indigenas, non-industrious, depraved, unruly, serve no social purpose and need to be channelled into production, a life to which men are all obliged to," says Juan Bravo-but this "non-economic" spectre, of overpriced workers or counter-productive practices, was a generic and ubiquitous presence in the colonial mind. The Curaduria was tasked with drawing in people who were not seen as inhabiting the same space, who at best now resided in the realm of 'native policy' or in the hinterlands beyond the fictitious but extraordinarily effective notion of the "economía". What colonial capital upheld when it talked of the economia and its "interests", was the separation between existing social forms of activity, creation and exchange from a politically-organized extraction geared to the metropole. ${ }^{43}$ Indeed they talked up this sphere, economía, to enable the weaving and spinning of recruitment and disciplining systems that came into existence to generate capital's expansion. Two of the most intelligent colonial scientistideologues, the economist Perpiña Grau and the jurist Cordero Torres, both repeat the same line: "the concept of colony and its economy do not express two concepts, but only one." 44 The contract is the essence of this imperial-capitalist hybrid. Colonial despots like capitalist despots, the "state, its police, and its army form a gigantic enterprise of antiproduction, but at the heart of production itself, and conditioning this production." The despotic capitalist bureaucracy "insinuates itself everywhere in the productive machine and becomes firmly wedded to it in order to regulate its productivity and realize surplus value." ${ }^{45}$

\footnotetext{
${ }^{42}$ See first two chapters of Mbembe, On the Postcolony, 28, for a theorization of the steps colonial violence took to mark its presence, implant itself and realize extraction. As "a productive agent" the colonized, "he/she was in effect marked (literally), broken in, compelled to provide forced labor, obliged to attend ceremonies, the aim being not only to tame and bring him/her to heel but also to extract from $\mathrm{him} /$ her the maximum possible use. The colonial relation, in its relation to subjection, was thus inseparable from the specific forms of punishment and simultaneous quest for productivity."

${ }^{43}$ Bravo Carbonell, Fernando Póo y el Muni, 386. Bravo employs the imagery of silver as a sign of smooth, flowing permanence: "It is indispensable to get to work right away, so that rivers of silver can start flowing from the colony to the metropole." The constant haunting of Spanish colonial officials was this thwarting of this "actualizing" or "unlocking of the wealth in the inscrutable forests", principally of human resources.
}

${ }^{44}$ Perpiñá Grau, De colonización, 45; Cordero Torres, Politica colonial, 528.

${ }^{45}$ Deleuze and Guattari, Anti-Oedipus, 341. 


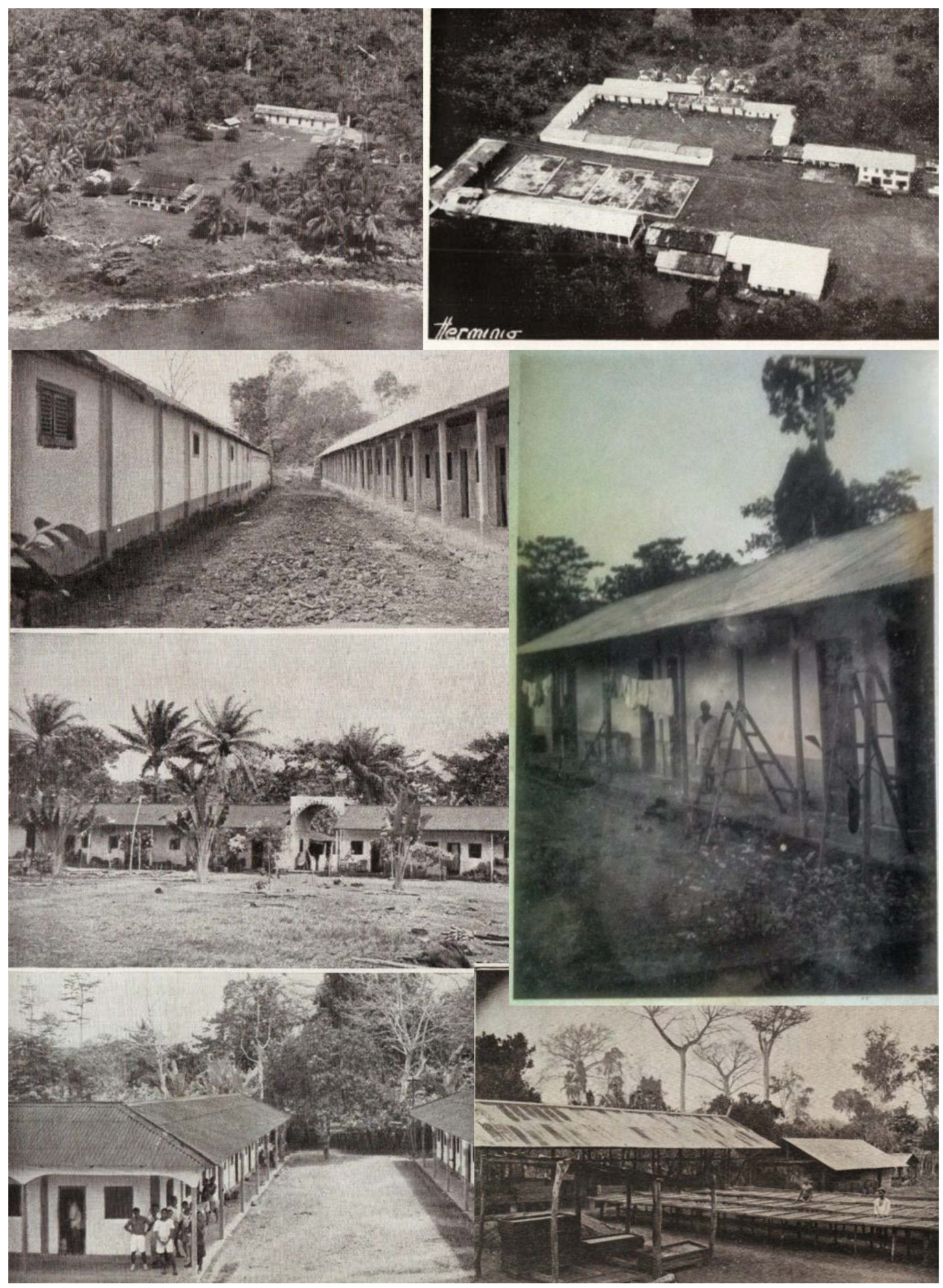

Figure 17 Fincas or plantations, twentieth century ${ }^{46}$

${ }^{46}$ Captions or description from From top left clockwise: Finca Tapé of Serra Parera; Patio of large finca, with drying beds or secaderos visible and above it the bracero living quarters; bracero living quarters of Finca Vaz Serra; cacao drying beds; bracero living quarters in Finca Santa Maria Tomazia; Finca San Eugenio. Sources: Terán, Síntesis geográfica, 50; Kicks-Dadzie, 'Confidential Report', September 1939, NAE, CALPROF 5/1/195; Rodríguez Barrera, Manual del agricultor en Fernando Póo, 50; entire left side is from Gobierno General, 'Memoria de la labor realizada en el período 1949-1955', 130-40. 
The Curaduría itself was founded in 1901 as a centralized tax-gathering instrument, an institution set up purely for extraction - in 1900 half of the colonial treasury's entire revenue came from a "tax of the registration of the Krumen and other workers." ${ }^{47} \mathrm{~A}$ Nigerian policeman explains how authorities were not there to prohibit or regulate, but to intercede and extract a slice of whatever recruiting arrangements planters had managed to mobilize or pay for: the "Colonial Curaduria collects a duty of SIXTY PESETAS on each boy imported", and he adds "What a shameful act Spanish Government too collecting duty on human cargos!"48 The state not only profited from structuring recruiting assemblages but even when it started fining planters for being avid customers of illegal recruiters, what it was essentially doing was increasing the proportion of value it could skim off from their on-going existence-levied fines were higher than an initial tax, but not a disabling burden for the employers or the recruiters. This was so until the early 1950s - until then if anyone was being jailed or deported it was only a few of the lowlier ganchos.

The machinery of the contract emanated from the Curaduría in Santa Isabel. In the early 1920 s, when the operations of touts were at their lowest due to the labour treaty with Liberia, some leading planters were sceptical of the conditions underwritten in the contracts set up by the state. The contract "cuts the opportunities of braceros to lodge complaints, because even if well founded he will be sent to a brigada [prison brigades]. Everything goes against the braceros. If we apply these laws the braceros will all disappear within a few months [...] the employer cannot be dignified if the bracero is turned into a slave". ${ }^{49}$ Contracts were onerous to say the least, a paper clutched by employers as the reason for why their commands and expectations must be obeyed, a pretext for continuous harassment and assault by overseers. The Spanish "labour code bears the marks of having been compiled by employer to safeguard the privileges of the

\footnotetext{
${ }^{47}$ Ricardo Beltrán y Rózpide, La Guinea Española (Barcelona: Soler, 1901), 159.

${ }^{48}$ S. Muyiwa to Commissioner of Police, Calabar, 24 May 1936, NAE, CALPROF 5/1/194. "Does it then not also prove that the Spanish Government is aware really of this abominable traffic? Of course Spain can never stop oppression, Slavery and forced Labour."

${ }^{49}$ Cámara to GG (Barrera), 1921, 'Sobre moción presentada por la Cámara Agrícola en el gobierno general de Fernando Póo formulando propuesta de modificación en el Reglamenta del Trabaja indígena', AGA, C-81/06400; cited in Sanz Casas, 'Política colonial y organización del trabajo', 223.
} 
employer". ${ }^{50}$ The contract goes some way to explain why the "condition under which they toil are the equivalent of paid slavery" or why "workers are engaged under the terms of a charter which is a twentieth century devise for slave dealing." ${ }^{\circ 1}$ Sergeant Muyiwa, relates actual working conditions found on the worst plantations on the island well into the early 1950s. Broaching Orlando Patterson's thesis of the relationship between slavery and death, he says those "captured from Calabar and Port Harcourt are subject [to] work from six in the morning to six in the evening rains and sun - their masters at their back with canes in hand watching any one that would lift up his head for a second and if there be any that would lift up his head for a second - it is the cane that will tell him that his master has paid dearly for him and as such he has not right to rest even for a second. Is this not more than Slavery? Is this not more even more than Killing?",52

After going through the conditions on the plantations, a Spanish journalist on Fernando Pó writes that "sure the planters over-work their braceros, but that's not slavery". He then poses and answers his own rhetorical question: "so the exploitation of the African is based only on the contract? Pretty much, yes." 53 Another more scandalized Spanish journalist in the 1930s_-Guillermo Cabanellas in his j'accuse exposé 'jesclavos!'adds details that were largely true if not always continuous. The contract was "slavery in every sense of the term, because the African cannot release himself from a contract made under the pressures exerted by the delegates of the colonial administration, when not by outright brutal force exercised by the gendarmeria or the deception of a professional recruiters. The sale price ranges from one to five hundred pesetas, with the obligation to serve for a period not less than two years." For the bracero "the contract is irrevocable even though it was not made and carried out on the basis of contractual

\footnotetext{
${ }^{50}$ British VC (Michie), 28 February 1941, 'Labour Conditions', para. 13, TNA, FO 371/26908..

${ }^{51}$ Peter Pan, 'The Brutal Island', Daily Times, Lagos, 27 January 1965.

${ }^{52}$ S. Muyiwa to Commissioner of Police, Calabar, 24 May 1936, NAE, CALPROF 5/1/194. For the use of whips, canes and outright murder, in a very large handful of plantations, where braceros were "beaten with a rubber truncheon and often kicked severely whilst on the ground" and "kept without food or wages". see British VC (May) to Under Secretary of State, London, 30 April 1936, TNA, FO 458/126; Curaduría (Ordoñez), 23 January 1932, 'Sanciones', AGA, C-81/07720; Eyo Udo, 8 September 1941; GG (Fontán) to British VC (Michie), 27 November 1941, AGA, C-81/08128, E-12.
}

${ }^{53}$ Madrid, La Guinea incógnita, 111. 
law. The contract assigns, attaches him onto a plantation like a serf. They have no rights during the duration of the contract, but they do have cruel obligations. They lack all, including the right to complain". ${ }^{54}$

A small seam of the archive contains the un-histories of 'free' labour. An unsuccessful petition of indigenous Bubi farmers on Fernando Pó in 1931 already proposed to the first Republican Gobernador that braceros "should be freely allowed to search out diverse patrons, and be paid on a daily basis", because, they claimed and witnessed, for those "now entering into a contract, for the braceros, means bad treatment, and many deaths from being overworked and beaten by the masters, all for 20 pesetas a month?" The small Bubi and Fernandino farmers had from early on openly opposed the contract system represented by the Spanish labour office, because the vast majority of them could not actually hire labour at all through the Curaduria. Only settlers and a small number of African elites_emancipados - could make contracts with workers: "so that the labour question will apply to all equally, we need to make the CURADURIA disappear." 55

\subsection{Vagrancy}

In schematic and largely valid terms, the change in the structure of the colonial economy - the growth of towns, warehouse and plantations-generated a shift in colonial discourse - of which tropes where mobilized to describe Africans on the

\footnotetext{
${ }^{54}$ Cabanellas, ;Esclavos!, 21.

${ }^{55}$ Jefes Bubis to GG (Manresa), 28 August 1931, 'Proposiciones de los hijos del Pais. Los Bubis', AGA, C-81/08028, E-2. Even for those who could hire labour, their main issue with the contracts seemed to be also that of "depositing the wages in the Curaduria" which is "impossible for us", the undercapitalized small farmers. From 1938 on, labour could only be contracted by those with a "canonical marriage" certificate. Ballano, Aquel, 527; Nsue, Historia de la colonización, 215. While flourishing well into the twentieth century, small African farmers barely survived and were slowly expropriated by the large cacao exporting houses in Santa Isabel. These merchant warehouses could hire braceros and so they would rent braceros out to different small farmers in 'exchange' for an artificially lower price of cacao. "These creditors have no interest that there be an abundance of braceros, well the small farmers and their produce would otherwise escape from their clutches." Anonymous, Santa Isabel, 17 August 1951, 'El problema de braceros en Guinea Española', AGA, C-81/12373, E-392. The John Holt "papers indicate that the key to securing cocoa from smaller Creole farmers was to provide services, such as credit, secretarial help, and labour at harvest time." Clarence-Smith, Cocoa and Chocolate, 120. In the late 1950 s the so-called "cooperativas indigenas del campo de Fernando Poo" organized the Bubi farmers by villages and localities and through these they could hire braceros, the 30 cooperative hired about 169 braceros in the late 1950s. Patronato de Indígenas de los Territorios Españoles del Golfo de Guinea, Santa Isabel, 1956, 'Datos para su historia y antecedentes y memoria del 1954', BNE, D/16263.
} 
island, of which legal codes were elaborated upon and more thoroughly enforced. As elsewhere in early colonial urban Africa, the early contours of a racist colonial ideology of "disease and inactivity", with which both the decimated indigenous Bubi population-mourning with alcohol — and the unregistered immigrants were being enveloped with, quickly shifted by the 1930 s to the superimposed label of "criminality". 56

The "sole mission" of the Curaduria, writes the Curador, David Carrillo in 1936, was "to exercise a tutelary function for the indigenas, both nationals and foreigners, and to prevent that these be enslaved in any form." Carrillo continues to say that while "our ordinances contain only the most just and humane orders", it is only when these are "transgressed" that "peonaje follows, and in some sense this is similar to classic slavery". ${ }^{57}$ Penal labour was unpaid and potentially perpetual, a kind of slavery; it needed no recruiters, only the architecture of the force of the state. ${ }^{58}$ Cordero Torres,

\footnotetext{
${ }^{56}$ Joel Glasman, 'Unruly Agents: Police Reform, Bureaucratization, and Policemen's Agency in Interwar Togo', Journal of African History 55, 1 (2014): 79-100; Odile Goerg, 'De la ségrégation coloniale à la tentation', in Security, Crime and Segregation in West African Cities Since the 19th Century, ed. Laurent Fourchard and Isaac Olawale Albert (Paris: Karthala, 2003), 245-63; see also Rogers, 'Vagrancy, Impressment and the Regulation of Labor in Eighteenth century Britain'.
}

${ }^{57}$ Curador (Carrillo) to GG (Sanchez Guerra), 4 July 1936, AGA, C-81/08028, E-6; Carrillo only very briefly held the post during the Republican period.

${ }^{58}$ The relentlessly violent role of the violence of the state, whether in legal penal contracts or the creditinduced status regimes of bondage have for good reasons came to forefront recent labour history literature. Too much ink has and continues to be spilled as to whether "extra-economic" coercion or "non-pecuniary pressure" is to be located in revamped militaristic feudalism of "primitive accumulation" or whether it is an always central backdrop and operational presupposition required for all capital to engage in the most profitable aspects of its work. Capital can accumulate irrespective of the precise form or length of subjection and its corresponding status. Violence is always there and here, even in the most liberal and visibly peaceful places. Try telling a striking worker in Shenzhen or a homeless person going in and out of jail or an undocumented immigrant being deported that the threat of violence and violence itself do not play a role in capitalist labour markets. A footnote to this footnote. This is of course a repeat of a tweaked Marxists explanations that came with the more anarchist rediscovery of the "primitive accumulation" chapter in Capital. Violence, "the concentrated and organised force of society" was deployed as force that was itself an "economic power." Marx, Capital, 776. The quote famously continues of course with the "transition" "of the feudal mode of production into the capitalist mode". It is unexpected for both Marx and Engels to insist so much that "primitive accumulation" was "transitional" since in both Marx and Engels this political power is there from beginning to end. Engels posits a somewhat precise breaking point for when "slavery had been invented", exactly when "labour-power acquired a value": when the pre-ancients stopped simply killing prisoners of war, these prisoners suddenly "acquired value; one therefore let them live and made use of their labour. Thus force, instead of controlling the economic situation, was on the contrary pressed into the service of the economic situation." Engels observed that the "enslavement of man" during his time in more "highly civilised states [where there] is wage-labour" was being "mitigated", yet it could only proceed "to a greater or lesser degree” by being “carried on under police rule.” Engels, Anti-Dühring, 170, 162. 
the jurist atop it all, noticed a similar distinction. He says he did indeed "consider as forced labour the semi-penal labour undertaken with those whom are considered socially dangerous and undesirables, under diverse laws of public order and those relating to vagos y maleantes [vagrants and miscreants]. ${ }^{, 59}$ It was fine distinction that did not hold up, since in effect anyone without a labour contract or anyone who was not a recognized landowner, was now folded into the juridico-status regime of the vago-in addition to possibly being a "tributary" or other subject, where the 'educational' telos and hubris of "tutelage" showed up to varying degrees. The vago was strictly a corollary of the order of contract: "if indigenas from a neighbouring colony should not find work within the said 15 to 30 days, they enter into the category of vago" ${ }^{60}$

All throughout the first half the twentieth century, planters were always anxiously awaiting any trickle of immigrants who could be lodged in their plantation patios, but many new arrivals did not sign contracts; they were traders. They "arrive without any background checks, and with a simple municipal license fill a stall with fabrics and tinned food and start to work." Those who came more or less in accordance with their own intentions and designs were unwelcome. The question was how to bring over people and make them stay as braceros. Only recruiters, harnessing the power of the contract, could make this happen. The colonial authorities in the 1910s and 1920s did not need to worry much about African itinerant migrants, as they largely did not exist. A bundle of registries and pass-laws was also first issued on the island in 1908, and aimed to "reduce the possible number of vagos y maleantes [vagrants and miscreants] of colour who circulate through the towns, villages and pathways of these territories." In addition all braceros had to carry a "pass, plaque, or card" with the "name of the

\footnotetext{
${ }^{59}$ Cordero Torres, Política colonial, 543. See also Clavero, Bioko, 21, 56. In most African colonies, international gold-standards were ratified and generalized from the 1930s on after the ILO conventions regarding forced labour (1930), and the recruitment of "indigenous workers" (1936) gave way to new labour departments and legislation. All these new benchmarks had surprisingly little bearing on Spanish Guinea. The Spanish delegate at the various ILO meetings in the 1930s, observed with relief that nothing was said about contracts as this "would have been too complicated", because a reformist attack on the contract - its actual form and practice-would have immediately and automatically conflicted with colonial capital. El Consejero Tecnico a la XIX Conferencia Internacional de Trabajo (Cavestany Anduaga), 22 May 1935, AGA, C-81/12422. See also Benoit Daviron, 'Mobilizing Labour in African Agriculture: The Role of the International Colonial Institute in the Elaboration of a Standard of Colonial Administration, 1895-1930', Journal of Global History 5, 3 (2010): 479-501; and Cooper, Decolonization and African Society.
}

${ }^{60}$ SubGG to GG (Bonelli), 8 June 1944, AGA, C-81/08182, E-6. 
carrier, place of work, date of contract and signature of the master". ${ }^{61}$ However under the oversight of the Republicans the first and wholly unexpected, "mass immigration" alarm was rung and the call for "coercive," "restrictive measures" found a radically amplified field of operation- 'outsiders' within. ${ }^{62}$

When the Spanish Republicans prepared their "delicate study of the material" on vagrancy laws they came across the indispensable "necessity of colonial regulations that have been implemented since distant times, the French since 1853 have had decrees related to immigrants workers in their colonies, similar norms have been taken up by England, Portugal, Italy and Belgium", norms that would "avoid that the colonies become places of refuge of vagos y maleantes if not undesirable people of a political order". ${ }^{63}$ The Gobernador, Estanislao Lluesma, quickly passed a decree in December 1933: "All those overstaying a thirty-day visitation period [and] those immigrants who are known, or suspected to be in a condition of vago, shall be interned in the barracones de Curaduria". Those who "lack licit means of living, will be kept until they contract" or until they are "forcibly repatriated and deported." 64 Lluesma left office within a few months and anyhow the types of paperwork required to avoid arrest were quite easily acquired or bypassed.

A lucrative 'underclass' was taking shape in a parallel economy alongside the plantations. This elaborate service sector built around the plantations consisted of liquor-vendors, ruffians, healers and pharmacists, paper-forgers and cacao smugglers-

\footnotetext{
${ }^{61}$ GG (Centeno), 1 December 1908, 'Vagos y Maleantes', Boletin Oficial de la Colonia. This was reiterated in 1926. "Con el fin de no original perjuicios a patronos y braceros con la recogida de vagos ordenada por este Gobierno, y en tanto no se reciban las pulseras de identidad y las adquieran aquellos para sus servidores, se provera a estos de un papel, chapa o carton en el que el dueño, gerente o amo haga constar el nombre del intereado, clase de trabajo y numero de contrato." GG (Núñez de Prado), 1 May 1926, 'Identidad de Braceros', in Boletin Oficial Colonial; In the Francoist period, the paperwork was extended for residents and non-braceros with a series of Civil Registers and "Family Books" or Libros de Familia, that also obliged all to notify a change of address within eight working days, see Cordero Torres, Tratado elemental de derecho colonial español, 160-2. For south African civil registry see, Breckenridge, 'No Will to Know'.
}

${ }^{62}$ Llompart Aulet, Legislación del trabajo, 123; 'Hospitalidad Excesiva', El Defensor de Guinea, Santa Isabel, 2 November 1933; GG, 28 March 1930, AGA, C-81/07720.

${ }^{63}$ DGMC (Duque) to GG (Lluesma), 8 December 1933, AGA, C-81/8156, E-3.

${ }^{64} \mathrm{GG}$ (Lluesma), 15 December 1933, 'Decreto de 2 de diciembre de 1933; see Curaduría (Guillén), 1 Novemeber 1934, 'Instruccion' in 'Boletín Oficial de los Territorios Españoles del Golfo de Guinea', Suplemento, November 1934, AGA, C-81/08126, E-1. 
“ambulant buyers of cacao", "especially Lagos [people], who are eminently of the commercial type". ${ }^{65}$ The colonial imagery of the vago, was crystallized in the "unassimilable" "Hausa mafias" ${ }^{66}$ who were represented as speculators, landlords of the slums, currency converters, peddlers of 'African' souvenirs sold to settlers and tourists, and 'quack-doctors' - "the Hausa who dedicate themselves to fetish-making and medicine." ${ }^{97}$ Hausa healers were held in very high esteem by braceros from all over the Gulf the Guinea; they were "reputed to be poisoners, healers and diviners of causes of ill-health; they prescribe remedies against evil by selling a simple rams' horn for 500 pesetas [or] a little piece of paper written in Arabic wrapped in a black cloth" for 25 pesetas. When accosted by the authorities they could "defend themselves with the papel de libertad needed to work as independents [as tailors or carpenters for example] and they leave with an air triumph to secretly return to their penchant" for "selling medicine." ${ }^{68}$ In the early 1930s there were "some 2500 Yaundes, as well as an infinitely higher number of Hausas and Lagos, of English origin, and a quite considerable figure hailing from Calabar, Port-Harcourt, Victoria, Duala, Cribi, Tiko, Sierra-Leone, Monrovia, Accra y Opobo, which means that the number of resident foreigners on the island is far in excess of Spanish subjects" - as underlined in the original text of this very alarmed letter by the head of the colonial office in Madrid in 1933. ${ }^{69}$ The African population on the island — now almost wholly immigrant—were seen as outsiders living within, not as subjects to be moulded. They could be exposed, without the veil of paternalism, to the extraordinarily spiteful imperial state.

A host of new registration regimes and paper templates were mulled over and prepared by the Republicans at considerable expense, but the revamped vagrancy law only hit

\footnotetext{
${ }^{65}$ Jose Pinto Guimaraes to Ricardo Ferrer Barbero (Comisario de la Republica e Inspector de los Servicios del Golfo de Guinea), 15 August 1931, AGA, C-81/08095, E-17.

${ }^{66}$ Pélissier, Los territorios españoles de Africa, 48; García, Fernando el Africano, 35; Baguena, Manuales del Africa Española, 52.

${ }^{67}$ Cámara to GG (Fontán), 13 April 1938, 'BRACEROS: Nota de la reunion con la Junta Directiva', AGA, C-81/08126, E-1.

${ }^{68}$ B.P., 'Brujerias de Extranjeros', La Guinea Espanola, Santa Isabel, 17 September 1939.

${ }^{69}$ DGMC (Alvarez-Buylla) to Presidencia del Consejo de Ministros (Guillermo Montauer), 20 July 1933 'Aumento de poblacion extranjera en los territorios espanñles del Golfo de Guinea', AGA, C-81/06467, E-19.
} 
the ground in their last month in office. ${ }^{70}$ It was to be expected that colonial laws, labour laws among them, were re-implemented with an unprecedented literalism by the Francoist regime from September 1936 on-whose 'early phase', uncompromising and virulently fascist, as in Spain, lasted well into the late 1940s. ${ }^{71}$ In Spanish Guinea the vagrancy code specifically target the Nigerian "los traders", as the Spanish liked to call them-anyone who "worked on their account". ${ }^{72}$ The Francoist customs officers were given the mandate to "let no one embark on ships, except those duly authorized," barring those who had "outstanding obligations in these territories," or who were "considered vago and who cannot show the required documents". ${ }^{73}$ Vagos could not leave the island except through arrest and deportation, only someone with a "freedom paper"-issued after the expiry of a contract-could. The traders dispersed and partially regrouped. It was only under these revamped series of ordinances that allowed a series of Nigerian traders to splinter off and become Fernando Pó's most effective recruiters yet. Effective because of the presence of the prison and punishment. The contract was not a communication; it was your name in a registry, a necklace, a number, a tin plaque, an addendum to the forces of registration and legibility. What sustains these forces? It would be tautological to say 'mechanism for identification', since that is only one of their effects. It is violence, structural violence and actual violence $^{74}$ - the latter when necessary, as it so often was, was undertaken by the state, after all, modernity purified the public and the private into their respective spheres.

\footnotetext{
70‘ Ordenanza del 22 Agosto 1936. Vagos y Maleantes. Normas’, in Miranda, Leyes Coloniales, 1468.

${ }^{71}$ Indeed the Francoists held this Ley de Vagos y Maleantes, (Vagrancy and Rogues Code) intact until the end of the colonial rule in 1968, and in Spain until 1970. España, Ley de Vagos y Maleantes (1933), 192; see Salvador Cayuela Sánchez, 'La biopolítica en la España franquista' (PhD Thesis, Universidad de Murcia, 2010), 172-8.
}

${ }^{72}$ Sandinot, 'Guinea ecuatorial (española)', 94.

${ }^{73}$ Secretario General to GG (Fontán), 9 July 1940, AGA, C-81/08806, E- Expediente de Información con caracter reservado sobre incidente occurrido en Santa Isabel con un Buque de Guerra Ingles'.

${ }^{74}$ This is why Benjamin says, "a totally nonviolent resolution of conflicts can never lead to a legal contract. For the latter, however peacefully it may have been entered into by the parties, leads finally to possible violence." Not only that: "the origin of every contract also points toward violence" insofar as the "power that guarantees a legal contract is in turn of violent origin even if violence is not introduced into the contract itself." Benjamin, 'Critique of Violence', 288. 


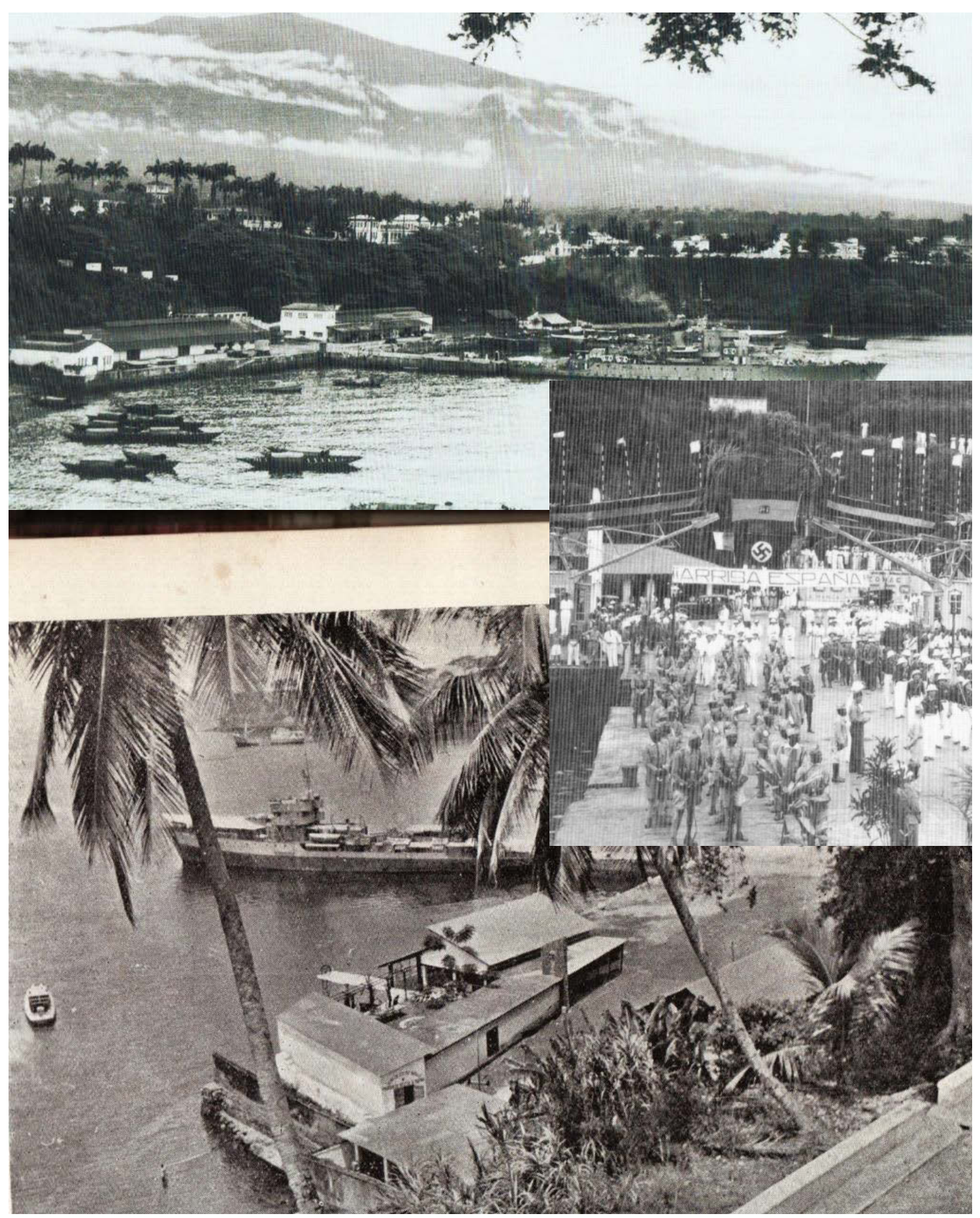

Figure 18 Port of Santa Isabel, 1940s ${ }^{75}$

${ }^{75}$ Photos clockwise from top to bottom; Martínez, Poto Poto, 40, 20; Unnamed and untitled small postcard like Photobook in BNM. 


\subsection{Law and Order}

Even though there were many cases of flogging by the overseers of plantation, the violent disciplinary scene belongs properly to the Guardia Colonial; systematic torture was displaced from private to public hands. This degrading "inhuman treatment" was not a matter of insider or outsider status, the "social and economic disabilities suffered by the British African community (resulting from their relegation to [the] inferior status)" of no-emancipado, had much "in common with Spanish 'indigenas' at the hands of the forces of law and order. Instances of brutality (such as flogging with rubber truncheons) and of imprisonment in semi-barbaric conditions, without trial or even the preferment of a charge" were reported daily, occasionally only weekly, by the British Vice Consuls. ${ }^{76}$ The Francoist officials summed up the role of the Guardia Colonial as "assuring the Empire of Law, serenity and order and assures the respect of the people and property of peaceful men."77

If "a labourer declined to accept the contract placed before him he can be treated under the existing Spanish laws, as a rogue and a vagabond." 78 Indeed the early Francoist archives are abound with petitions from imprisoned immigrants "who wish to be set free", a condition "those in charge do not permit unless we agree to be recruited". The Francoist Curadores had no qualms about keeping people in collective and deplorable jail cells for months on end: "for refusing to contract themselves, they shall remain in the barracoon." 79 The daily routine was "imprisonment and detention without trial", "prison conditions [were] semi-barbaric". The Barracones de Curaduría were long holding dens, without bathrooms: to relieve themselves inmates were marched off in

\footnotetext{
${ }^{76}$ Officer Administering the Government, Lagos to CO, 9 January 1948, TNA, CO 554/154/1.

${ }^{77}$ Yglesias de La Riva, Politica indigena en Guinea, 97. This is ancient imperial despotic hubris. In some of the earliest records of Middle Kingdom (2050-1786 B.C) along the Nile, the pharaoh was seen to have a "sacred duty to preserve public order" expressed in the "concept of mar ('justice' or 'order')" on whose principle "depended the equilibrium of the universe." Peters, 'The Prison before the Prison', 8.

${ }^{78}$ British VC (Michie), 28 February 1941, 'Labour Conditions’, TNA, FO 371/26908.

${ }^{79}$ Antonio Nsomoro and Simon Ebona to GG (de Mendívil), 17 June 1937, AGA, C-81/08153, E-1; Curaduría (Mondeda) to GG (de Mendívil), 2 June 1937.
} 
the evening anywhere near the ocean under the supervision of armed guards. ${ }^{80}$ The cell at Santa Isabel's police station, as Pepple tells us in his first hand account, "held over a hundred prisoners who slept there, almost one over the other. The place was a boiling cauldron of carbon dioxide with a repugnant stench of urin and faeces, and the idea came obsessively to mind that committing suicide would be the only way out" ${ }^{81}$

As if to parallel the total imbrication of the state in the market, the Francoist regime actually started charging prisoners for their own maintenance cost. ${ }^{82}$ Those who fell into the category vago were arrested, put to forced labour, and were charged their own maintenance cost, a contract was usually the only way out — as the Nigerian Johsin Oke had the misfortune of finding out after being imprisoned "for having wanted to abscond from service without having completed the four year contract". He quickly petitioned the Governor: "not having any help to cover the costs of prison and not knowing how much longer I could remain in said prison [...] I SUPLICATE: please let me finish the contract $[. .$.$] a job that will be fulfilled with zeal." { }^{\prime 83}$ A British missionary writing in the 1950s notes sarcastically that "Spanish prisons do not provide food, they don't believe in pampering their inmates". ${ }^{84}$ In 1961, a visiting Nigerian Minister of Labour expressed "his disbelief that some Nigerians who committed offenses, and as a result thereof, and after having been deployed in all sorts of penal labour, were charged their own maintenance costs". 85

\footnotetext{
${ }^{80}$ British VC and LO (Rylands) to Commissioner of Labour, Lagos, 11 July 1947, 'Labour Report No.7/1947', NAE, CALPROF 17/1/278; British VC and LO (Rylands) to Commissioner of Labour, Lagos, 8 January 1947, NAE, CALPROF 17/1/278.

${ }^{81}$ Isaac Pepple, 16 June 1956, ‘17 dias en una prision española’, AGA, C-81/08221.

${ }^{82}$ This was not so earlier. The Republican treasury prepared elaborate measures for provisions and even paid penal labourers considerable wages. See AT Santa Isabel to GG (Sánchez Guerra), 13 December 1935, 'Proyecto de Organizacion de la Carcel Santa Isabel', AGA, C-81/08134.

${ }^{83}$ Johsin Oke to GG (de Mendívil), 29 January 1937, AGA, C-81/08153.

84 'Newsletter No.3, Fernando Poo, Spanish Equatorial Guinea, August 1952', in David Lawrence, (unpublished memoirs, 1999), 'Faith Hope Love: A Legacy', 45, SOAS, London, MMS, MMSL MSS/028. Should a prisoner "have no means of obtaining food" he would be allowed on 'parole' having to "return each night to the prison until "he has enough money to pay for his food bill." Though this only if they weren't being put to work.
}

${ }^{85}$ SubGG (Suances), 22 May 1961, 'Visita de Region Ecuatorial de la Mision Nigeriana por el Ministro de Trabajo Federal Sr. Johnson', AGA, C-81/13039, E-392. It seems a new Curador tried to put a stop to 
Even in 1962 Spanish colonial law did "not consider" prestación as "forced labour but rather obligatory," with a strange introjection or rendition along the thought-lines of 'compulsory education' that rendered anyone on the island subject to the state's "fiscal and educational policies." As José María Cordero Torres, the foremost Spanish fascist colonial jurist, says: this "obligation to labour" was taking place "under a framework of militarization" but it "was paid and limited in time" — so, he probably surmised, it "was not slavery-slavery'. The same reasoning was applied to contracts. ${ }^{86}$ It was even the Republicans who articulated most consistently the mystified legitimation of forced labour, even while they initially abolished it and never re-implemented it on a large scale: "in general, we believe, that forced labour turns the indigena into a slave, but in this case, forced labour" will be directed for "their own benefit" because it was a tool to battle the "state of nature" itself, "the vice of idleness". ${ }^{87}$ Imperial formations forging the conditions of extractive and endlessly expanding output worked "not just by moral compulsion, but above all by using moral compulsion to mobilize sheer physical force." 88

They did not make the common theoretical—liberal and Marxist-distinction between the "individual" exploitation of debtors, wage-labourers or serfs and "collective" or state coercion such as conscription or convict labour on the other ${ }^{89}$ Colonial sources almost never make this distinction, in fact they put all their efforts into actively propagating their continuous entanglement. On Fernando Pó those conscripted suddenly signed contracts; free people received advances and entered contract on their own volition but became contracted and were subjected to serf-like relations enforced only by the violence of the state; contracts were decreed obligatory; corvée or prestación was explicitly intensified to funnel people into contract; contracts exempted

it, it is uncertain whether the Governor took his advice. Curaduría (Hanza) to Secretario General, 13 March 1962, AGA, C-81/08214, E-1.

${ }^{86}$ Cordero Torres, Política colonial, 543; See also Clavero, Bioko, 21, 56.

${ }^{87}$ Arizcun and Martínez, 'Memoria sobre los territorios españoles del Golfo de Guinea', 126, BNE, Afr/13541.

${ }^{88}$ Graeber, Debt, 346.

${ }^{89}$ Geoffrey E. M de Ste. Croix, The Class Struggle in the Ancient Greek World: From the Archaic Age to the Arab Conquests (Ithaca: Cornell University Press, 1981), 44; Graeber, Debt, 127-165. 
from indefinite detention in prison; prisoners could purchase their release by signing contracts. Because of these tightly interwoven labour packages, "wage labor" appeared to many colonized subjects from a local "point of view [as] a mere extension of forced labor, which in effect it was." 90 The only thing that remained constant was the contract as a branch or effect of forced labour emanating from the tributary and criminal justice system.

Forced labour had no difficulty expressing Spanish Guinea. Unfree labour was not couched in a regretful tone of expedients. It was not the constantly reverted to underbelly of colonials half-heartedly wishing for "free labour". We need not take "the history of unfreedom [a]s the history of capital in disguise", ${ }^{91}$ almost without hesitation it was openly lauded and morally valorised throughout the planter's reign in Los territories españoles del Golfo de Guinea. Unlike their more paranoid and sicklier northern European counterparts, the Spanish in West Africa showed no self-restraint in becoming settler colonials and letting the uncompromising conditions for their economía colonial unfold. "The Portuguese, with blood from the very same mother, have been living for centuries in Sao Thome e Principe, right next to Fernando Póo." "There is no racial or climatic impossibility otherwise this would entail our disqualification as a country that colonizes. Sure we will have to foist discipline and engage in the spirit of sacrifice, but this will be combined with the stimulus of the State and so we have plenty of ways to achieve this". 92 "The system of forced or rather obligatory labour for works in the public interest or which increases the output of our agriculture" - a system of bondage that caused the deaths of tens of thousands, and the torture, actual torture and systematic beatings by guards, of hundreds of thousandswas said to have "no shortage of benefits. Its inconveniences are minimal, if one takes into account the benefits it represents for the development and stimulation of the economía nacional". ${ }^{93}$

${ }^{90}$ David Graeber, 'Love Magic and Political Morality in Central Madagascar, 1875-1990', Gender \& History 8, 3 (1996): 416-39, 427.

\footnotetext{
${ }^{91}$ Prakash, 'Colonialism, Capitalism and the Discourse of Freedom', 22.

${ }^{92}$ Cordero Torres, Tratado elemental de derecho colonial español, 259.

${ }^{93}$ Yglesias de la Riva, Politica indígena en Guinea, 327.
} 
Even in the 1960s the Curador - the first one under the Francoist with any appropriate legal training - reiterated "labour as a social duty that can be required from anyone in the Region Ecuatorial Española without impediment. This is in conformity with the laws in force; tributo obligado stimulates the wealth and assets of the patrimonio nacional." 94 When Ghana started bringing forward international legal claims against Portugal for failing to enforce the 1957 convention on forced labour-that Portugal actually ratified soon after - the Spanish started worrying. The Spanish did not sign this new treaty on forced labour until 1967, but in the early 1960s they were trying to figure out how to pass through all these new international legal accords they had decided to open themselves up to. Even though Spanish Guinea had recently passed into the status of province in 1959, the Region Ecuatorial, the labour department was still of a "synthetic order"- after all "local peculiarities need[ed] to be taken into account". The colonial despot, the "Governor General [was] still taking the place of the [Spanish] Ministry of Labour". 95

"Some of the British officials in Nigeria" had "the unpleasant task of glossing over the reports of extreme brutality (cases of Nigerian workers being beaten to death were not unknown)". They sat by; sometimes "conscience-stricken"96 claims a colonial Labour Officer in Nigeria who opened his heart out to the Observer newspaper in 1961; other times they sat busily and pithily transcribing thousands of complaints, and sending labourers to the Curaduria telling them they "must obey Spanish laws," as confessed in a "secret and personal" letter from the British Vice Consul on the island in 1954. ${ }^{97}$ Nigerian political activists at the start of their independence were quite struck that a few miles from their shores lay an "appendage of Spain". Even though "every

\footnotetext{
${ }^{94}$ Curaduría (Robles Castillo), June 1961, 'Plan de trabajo’, AGA, C-81/13037.

${ }^{95}$ Ministerio de Trabajo, n.d. [1957 to 1958], 'Memoria sobre la aplicación a los territorios no metropolitanos de los Convenios ratificados por España.' AGA, C-81/13037. Only in the last five years of colonial rule did they try to "harmonize". The "special characteristics of these territories lead without a doubt to some difficulties when trying to completely apply Spanish legislation". Especially in regards to labour contracts these "laws were not uniform, and definitely not in accordance with the prescriptions contained in international conventions.” DGMC (Díaz de Villegas) to GG (Núñez Rodríguez), 23 May 1962, AGA, C-81/13037, citing letter from citing Ministerio de Trabajo, 21 May 1962.

${ }^{96}$ H.S. Smith, 'Spanish Guinea', The Observer, London, 30 April 1961.

${ }^{97}$ British VC (Muir) to British Consul General, Brazzaville, 28 August 1954, 'No.37 Secret and Personal', TNA, PRO CO 554/1345.
} 
legislation comes from Spain", the appendage had its own claws. The Nigerian Youth Congress saw the "Nigerian government's support of slavery on the island" as "a negation of panafricanism." 98 It was a negation of everything that had been arduously deliberated and fought for in the anti-colonial twentieth century-along the contours of its own space-time Fernando Pó had one big warped foot residing in the imperial-neoslavery of the nineteenth century and a few other places and epochs. Indeed anticolonial activist and the press started lumping Spanish Guinea together with Portugal and South Africa whose self-declared alliance in the 1960s was formed as "powerful political-military-economic of racists and colonizers fighting against the movements of national liberation." 99 The radical Zikist wing of the NCNC, the party of the first Nigerian leader Nnamdi Azikiwe, composed of millions of members of labour unions, associations and other parties, with a support base in the Eastern Provinces, listed the "annexation of Fernando Po" into the top four points of its resolution. 100 "Progressive organizations in Nigeria demand decisive action against the Franco slave-holders. [...] The movement in Nigeria for the liberation of Fernando Po is spreading. It is a grave warning to the Spanish colonialists who have made this beautiful island a hell on earth."101

The Nigerian journalist Peter Enahoro was one of the few outsiders who gained a glimpse of plantation life in Francoist Fernando Pó, by conning his way into one after disguising himself as a "Nigerian Labour Inspector from the Consulate"102. He goes on to ask: "is there forced labour in Fernando Poo? There is no slavery in the sense defined by the codes of international labour [organization]. But before you breathe a

\footnotetext{
${ }^{98}$ Linus B. Njoku, 'The Fernando Po Question', West African Pilot, Lagos, 3 February 1961; Olatunji Otegbeye, 'To the Youths of Nigeria', West African Pilot, Lagos 11 November 1961.

99'Portugal and South Africa: A Dangerous Alliance’, Morning Post, Lagos, 28 September 1965.

100‘27 Point Resolution by Zikists', Sunday Times, Lagos, October 16 1960. see also Akinyemi, 'Nigeria and Fernando Poo'; Obadare, 'Nigeria-Equatorial Guinea Relations'. They were prefiguring and echoing a crowd of editorial pieces and letters to the editor calling to "bring the noise of weaponry to defeat and expel them", "from now on: any map of Nigeria that does not include Fernando Poo is incomplete". 'Fernando Poo: The People's Voice', Sunday Times, Lagos, 18 March 1962. The United Labour Congress in 1965 pressed the Nigerian Government for a "policy of confrontation" with the aim of "sacking Spain from Fernando Po", "we demand action - a positive confrontation." "Call for action on Fernando Po island', Morning Post, Lagos, 27 January 1965.

${ }^{101}$ V.S, 'Hell on Earth', New Times, Lagos, May 1962.

${ }^{102}$ GG (Nuñez) to DGMC (Díaz de Villegas), 7 January 1961, AGA, C-81/11849, E-3.
} 
sigh of relief let us examine its alternative, the Ordinances that the Spanish have elaborated." ${ }^{103}$ Ordinances do indeed explain a lot. Mich Nwoke, a labourer who returned from Fernando Pó, sent this to a newspaper editor: "Those of us who have worked in FERNANDO POO know very well that a passport to that island is a passport to hell." He even says that Peter Enahoro underestimated the reality of "the brutal island" in his widely circulated exposé: "understandably for security reasons, [Peter Enahoro] did not stay long enough on the island. This short period of stay probably explains why he was so soft on the Spaniards". ${ }^{104}$ Journalists, parties, youth groups, and a variety of associations entered the civic arena to "act as liasons" and become representatives of the "illiterate labourers [who] can find no medium of expression and do not know the method of approach." They filled the space of representation with an unending spree of "atrocious and fretful news [...] about the inhumane treatment of Nigerian labourers recruited to Fernando Poo"- since the late 1930s "local dailies [had been] reporting atrocious acts of barbarity allegedly meted out by the Spanish Government to Nigerians in Fernando Poo."105

The British and Nigerian state kept signing off on the colonial labour treaties were "not keen to support the unjust campaign unleashed by the Nigerian press" but rather intent on participating in a geo-political ceremonial space of delegations and formalized inspection tours that always seemed to end with mutually supportive speeches "at the tennis club". When the Nigerian Minister for Labour visited Spanish Guinea "he stopped to chat with some Nigerian hospitalized patients. [A labourer by the name of]

\footnotetext{
${ }^{103}$ Peter Pan, 'Wickid Laws and Wickid Rulers', Sunday Times, Lagos, 25 February 1962.

${ }^{104}$ 'Fernando Poo: The People's Voice’, 18 March 1962, Sunday Times, Lagos.

${ }^{105}$ Secretariat of the Calabar Peoples Congress to Resident, Calabar, 9 June 1951, NAE, CALPROF 7/1/458; 'Ibo State Secretary asserts: Fernando Poo Once Part of Nigeria: Ownership to be disputed when Nigeria attains self-rule," Nigerian Spokesman, Onitsha, 16 May 1956. The Zikists already raised the issue of the ties needed for representation, when the only Labour Officer from the Nigerian administration was a white Briton, "it was already difficult for labour officers get in touch with labourers in Fernando Po, $[\ldots]$ an expatriate cannot win the confidence of the labourers." 'Proposal to bring affairs of Nigerians in Fernando Po under Chief Secretary Rejected', West African Pilot, Lagos, 19 August, 1954. While the British Consul attacked journalist and unions for not being detached enough: "The writing of a fair and objective article on the labor situation here is beyond their capabilities," a "sound judgment" was required, one which "junior freelance reporters" who "struggle" to "associating their names with sensational news" could not produce. The vocal members of the NCNC whose "opposition to the agreements in this country, insofar as it is compounded of tradition and emotion, is not amenable to reason." British VC and LO (Bradley), 14 October 1952, 'Labour Report, July 1st to 30 September 1952', TNA, FO 371/96714.
} 
Idjo, grumbled that an Official from the branch of the Labour Office did not attend the labour complaints put to him because he got along oh so well with the whites who showered him with diners and whisky". ${ }^{106}$

A non-militarized civic space could only emerge outside the island. The Spanish imprisoned and deported any Nigerians who were seen as "infiltrators" and "communist sympathizers"- anyone who had newspapers or other "documents written in English", anyone who was "too well-dressed", or who "was speaking in a certain way", anyone "who was uttering phrases related to the presence of braceros nigerianos on this island that have a possible political character"-and someone who was described as an "overeducated bracero" because the "collected works of J. Stalin" were found in his bag. ${ }^{107}$ As the daughter of the Francoist officer in charge of censorship says of her father's work-place duties: "nothing that alludes to black revolts, nothing that allude to the problem of slavery or slaving". ${ }^{108}$ The Spanish colonial archive is an exact inversion of this public censorship. Francoist propaganda did much to repress and remove any independent investigators who ventured into the island; these were thought to have "the ulterior motive of disobedience and sedition" bent on propagating "the infamous media campaign followed by ISAAC T. Pepple, who has disfigured the unrivalled civilizing action of Spain". 109

The African anti-colonial front against Fernando Pó was almost single-handedly activated by the accidental journeys of Pepple, and his tremendous revelations made in an article written for Drum magazine in 1957-an article that can be described as the "Pepple event". Pepple had been dispatched by the "Observer [newspaper] of Port Harcourt to do a story on the island"; initially he was only given "access to the model plantation" near Santa Isabel, so he proceeded to write "a glowing account of Fernando Po." "There it might have rested" Pepple says, "had I not required a holiday" for which

\footnotetext{
${ }^{106}$ SubGG (Gobierno Civil de la Provincia de Rio Muni), 22 May 1961, AGA C-81/13039, E-392.

${ }^{107}$ AT San Carlos to GG (Ruíz), 30 June 1956, AGA, C-81/08224, E-2; Jefe de Policía to GG (Núñez), 4 May 1962, and 3 April 1962, AGA, C-81/08803, E-s/n 622.

${ }^{108}$ Maria Dolores Fernández Fígares, La colonización del imaginario: imágenes de África (Granada: Universidad de Granada, 2003), 302, citing interview with Cecilia Bartolomé.

${ }^{109}$ Jefe de Policía to GG (Ruíz), 8 October 1956, AGA, C-81/08803.
} 
he decided to "return to this pleasant holiday island." "On the first day he stumbled upon "Meredith Pepple, a second cousin on my fathers side" who "had just been beaten up for not going to work for two days." After bringing this case to the attention of the British Vice Consul, a Spanish "police van arrived and I was whisked away to the common jail. Now this was their big mistake. For it permitted me to find out from the inmates what actually goes on in Fernando Po." Pepple was "convicted of sedition and fined 18 pounds" and spent three weeks in jail before being deported. From "prison", Pepple says, he "saw in all its nakedness the inhuman code of fascist oppression." Much can be gained from always including the perspective of the prison; posterity owes much to Pepple. ${ }^{110}$ The prison changes the equation, but it is the language of contract itself that veils this calculation as one rooted in something other than violence.

\subsection{The End}

Before their almost complete flight or expulsion from the island shortly after independence in the spring of 1969, planters had been producing up to $3 \%$ of the world's cocoa. They had generated growth rates of 3 to $7 \%$ in the post-war decades. On the back of an explosive global growth, the Governor, Faustino Ruiz (1949-1962) christened his long reign the "great flourishing": "a real surprise these last few years: cacao production has doubled since 1943 [and] timber exports have quadrupled."111 When the economía imploded after independence recruitment for contract labour did not come to an end. Though recruitment with Nigeria ends strictly with decolonization in 1968 during the intensification of the Nigerian civil war.

Macias was democratically elected. Nigerians did not get to vote-if they had been the outcome would not have been different. The early mood amongst Nigerians on the

\footnotetext{
${ }^{110}$ Isaac Pepple, 'Free Ticket to Hell', Drum, Lagos, April 1957; Isaac Pepple, 16 June 1956, '17 dias en una prision española', AGA, C-81/08221. See also Berman, 'Pepple's Story: Footnote to Spanish Guinea'. Pepple's genealogy is uncertain but he was from Bonny, so likely from the very notable royal household of the "ex-King of Bonny" Dappa Perekule Peppel, see Lynn, 'Factionalism, Imperialism and the Making and Breaking of Bonny Kingship'; on King Peppel's exile in Fernando Pó in the 1840s see Baikie, Narrative of an Exploring Voyage up the Rivers, 334-6. For this investigative genre pioneered in Drum magazine, see also the case of the South African journalist Henry Nxumdo, who in 1952 went undercover to a settler farm in Bethal; see Toyin Falola and Tyler Fleming, 'Africa's Media Empire: Drum's Expansion to Nigeria', History in Africa 32 (2005): 133-64.
}

${ }^{111}$ Pélissier, Los territorios españoles de Africa, 44, 62; DGMC, 1960, 'Repercusiones en la regional ecuatorial española, de la situacion general en africa', AGA, C-81/11852, E-4. 
island was pro-Macias, he had after all supported Biafra in the realm of relief logistics by allowing the airport of Santa Isabel to be used by a variety of humanitarian organisations - and, it was widely presumed, also by mercenaries. These had already been landing in the summer of 1967. The Spanish supported Biafra because the movement, the last Spanish Governor said was "Christian, anti-communist and antiBritish". In the late 1960s, the number of canoes going between the island and the Cross River "exploded, they [were] transporting all sorts of supplies", principally foodstuffs but also weapons. A general of the Nigerian military warned the Spanish "that it better be only cognac". ${ }^{112}$ The Anglo-Spanish Employment Agency ceased operations in late 1967, the flights and steamer connecting Calabar and Santa Isabel were withdrawn. Alfredo Jones, the head of the Agency and Spanish Consul in Calabar, fled to Lagos. In the summer of 1967 the Spanish on Fernando Pó created "campos de concentración for those Nigerians que se nieguen totalmente a recontratarse"-those "who refuse to recontract" as well those rendered "useless, by accident or by having an air of incompatibility with employers." The "workers will have to be inclined to accept a forcible prolongation of their services, which will be paid, seeing that it is impossible for them to return home". 113

Until 1969, the "events in Biafra led a great number of refugees coming to Santa Isabel", who according to the Nigerian Ambassador "were more than happy to be able to find work" on the island. In 1970 there "were at least 70,000 Nigerians distributed thought Equatorial Guinea". However within a few years almost all had left "Macias Nguema's Bloody Hell". ${ }^{114}$ When Nigerians departed or were finally evacuated from the island in January 1976, an op-ed by one prolific writer, "Signor Tofu" sums up the

\footnotetext{
${ }^{112}$ GG (Suances), 21 September 1967, 'Nota informative: Situacion en Nigeria’, AGA, 81/11849, E-1.

${ }^{113}$ Cámara Bata, 24 June 1967, 'Acta', AGA, C-81/09028, E-s/n 1029; Cámara Bata (Camprubi) to GG (Suances), 15 June 1967, AGA, C-81/13039, E-1001; Curaduría (Fernandez Riera) to GG (Suances), 19 June 1967, AGA, C-81/09028, E-s/n 1029.
}

\footnotetext{
${ }^{114}$ Kobel, 'La République de Guinée Equatoriale', 492, citing figures given to the author by the Nigerian Embassy in Santa Isabel, 1972. Most of the Nigerians on the island were Igbo and they were purposefully ignored by the Nigerian Military Junta. But in late 1971 under the threat of invasion and mass evacuation, a treaty to regulate the labour of Nigerians on any remaining plantation on the island was signed on the 31 December 1971 but in terms of recruitment, it was a complete failure, "absolutely no one wanted to go work in Equatorial Guinea" and "anyone remaining on a contract wanted to be repatriated." Inyang Udoma, '20,000 Nigerians Expected Home', The Nigerian Chronicle, Calabar, January 151976.
} 
mood: after "four decades of torture and enslavement, wellcome back to Nigeria. You did not deserve to suffer so." "Nigerians have suffered down through the decades of the 20th century, from the days when they arrived in large dug-out canoes with the connivance of the waves." "For all intents and purposes it has been a sorry saga, a history of human degeneration, a chapter of mans inhumanity to man". ${ }^{115}$

Nigerians started leaving en masse in November 1972 after street riots over unclaimable wages were responded with a massacres by the Guardia who shot into the very compound of the Nigerian embassy. About 20,000 people were evacuated by the Nigerian government. In January 1976 the Nigerian head of state, Murtala Muhammed, pulled the final straw: "charging 'barbaric treatment' of its citizens" he deployed the Nigerian military to organize the emergency evacuation of all remaining Nigerians and many Guineans who passed themselves off as Nigerians - 9,500 on planes and 15,500 on boats, during which at least 11 Nigerians were killed on the island. Bioko was left virtually depopulated, even Macias had stopped living there in 1972 for fear of being captured after many thought could be an imminent military invasion from Nigeria after the massacre at the embassy. Campo Yaounde lay abandoned, all "commerce came to a complete standstill". ${ }^{116}$ In terms of non-diplomatic foreigners only the French, Russian, Chinese and North Korean corporations, technical assistance staff and construction workers remained. The only shops were state-run and sold Chinese goods, principally tinned spam-meat and grey "mao suits".

A forced recruitment of 25,000 Fang peasants and "vagrants" from Rio Muni managed to salvage the island's cacao harvests in 1975-1976. A quota system of 1000 voluntarios or "volunteers" per district was arranged-principally through the same channels the colonial state had used, the schools and the prison and partly though appointed "chiefs". By the late 1970s the plantation economy-in the island that had been re-christened the Isla Macías Nguema Biyogo Negue Ndong-neared collapse.

\footnotetext{
${ }^{115}$ Signor Tofu, 'Welcome Back to Freedom', The Nigerian Chronicle, Calabar, 1 February 1976; Inyang Udoma, 'Stop the Fascist', The Nigerian Chronicle, Calabar, 18 January 1976.

${ }^{116}$ Interview with [anonymized], 12 July 2013, Malabo, Equatorial Guinea; Africa, 'Nigerian Exodus', Africa: An International Business, Economic and Political Monthly, March 1976, 57; 'Equatorial Guinea, Political Situation', 1971, TNA, FCO 65/928; 'Equatorial Guinea, Political Situation', 1972, TNA, FCO 65/1097; 'Equatorial Guinea, Political Situation', 1973, TNA, FCO 65/1294; 'Annual Review of Equatorial Guinea', 1975, TNA, FCO 65/1748.
} 
During Macias' rule, an estimated almost half of the Guinean population went into exile in Gabon, Cameroon, Nigeria and Spain. Thousands of "counter- revolutionaries" were executed extra-judicially by military personnel and the youth militias-called Marcha con Macias. The country underwent a self-proclaimed Maoist cultural revolution; expunging the "neo-colonial yoke"; the favoured line in many of the selfwritten anthems and poems of the Marcha con Macias ${ }^{117}$ Export of cacao fell from 30,000 tonnes in 1970 to as little as 2000 in the late 1970s, as much as the Fernandinos had been exporting by themselves around 1900. The total GNP imploded by $90 \%$, per capita income was 70US\$. ${ }^{118}$ The country was soon after taken out of the circulation of a long-standing state-led agricultural capitalism. Generals in Macias' armed forces ran any remaining plantations with prisoners; it is they who profited from the continuous last-ditch attempts to 'salvage' of the cacao harvest. Quite a few of these same generals currently run the government and presidency of Equatorial Guinea. ${ }^{119}$

${ }^{117}$ Partido Unico Nacional, 'Formacion Politica Anticolonial' (Santa Isabel: Diario de la Guinea Ecuatorial, 1971), BNM; Rufino Osa Mayona, Agusut 1969, 'Liberacion del yugo colonialist: Poemas de Marcha Con Macias', BACL.

${ }^{118}$ Wood, 'Business and Politics in a Criminal State', 3; Liniger-Goumaz, Small is not always Beautiful, 48.

\footnotetext{
${ }^{119}$ Interview with [anonymized], 6 May 2014; various interviews in Equatorial Guinea which for various reasons cannot be cited and acknowledged. There is a well-researched overview publication that is only available in the reading room of the BNM; Casa del Libro, Guinea Ecuatorial, Biblioteca Nacional, 'Historia Colonial de Guinea Ecuatorial', 2010, BNM. For forced labour see Union Revolucionaria de Guinea Ecuatorial and Akomamba, 'Una Alternativa Socialistas Para Guinea' (n.p, 1976), 20-2, BNM; Suzanne Cronjé, Equatorial Guinea, the Forgotten Dictatorship: Forced Labour and Political Murder in Central Africa (London: Anti-Slavery Society, 1976); Robert F. Klinteberg, Equatorial Guinea Macías Country: The Forgotten Refugees (Geneva: International University Exchange Fund, 1978), 28-32; Randall Fegley, 'Death's Waiting Room: Equatorial Guinea's Long History of Slavery', in African Systems of Slavery, ed. Jay Spaulding and Stephanie Beswick (Trenton: Africa World Press, 2010), 13559, 145-151; Mark Arnold-Foster, 'The Cocoa Slaves of Fernando Po', The Guardian, London, 12 November 1976.
} 


\section{Conclusion: Implications for the 'Spectrum'}

A look at the specific periods and places where touts ruled recruitment through economies of deception and escalation raises some interesting questions for global labour history and particularly for the 'mesmerizing contrast between 'free' and 'unfree' labour". That the "recruitment of labour proceeded in more complex ways than our stultifying orthodoxies suggest" is clear by now. ${ }^{1}$ The impression or lesson that Fernando Pó imparts is not smooth, it is not one of steady transitions or contiguous continuities but is marked by strange reversals and introjected reconfigurations. On Fernando Pó the creation of a labour market and the driving of labour into it proceeded in much more contradictory and unpredictable ways than the notions of "shifts" or "continuities" along the proverbial "free-unfree labour spectrum" suggest. To be sure, touts were one of the indispensable and varied rhythms of the "middle" of the spectrum, subsisting, economists would say, because of a scarcity or a border, in sectors where labour was in great demand, where a business had a high labour turnover, where working conditions were sub-standard. Touts were not simply a "blur" in the middle, their ossification into a type or their blurring into a segment of the spectrum forecloses the reasons for their existence and their range of manoeuvres and potentials. Touts, on either end, throw the conceptual pillars of clarity-free and unfree, coercion and consent-into disarray.

Recruiters cannot be adequately conceived as belonging to either free or unfree labour relations; though they could channel both. Their open-endedness lay not in the nature of their techniques but in how these intersected with the contract and the subjectivity of those they recruited. There can be no assessment of whether labour on Fernando Pó was free or unfree, or rather this exercise cannot emerge from an examination of the contract itself, nor from an imputed or registered abstract mental state of consent, nor from a consideration of working conditions on the plantations; these could be seen by different actors in a variety of ways, from a more paternalistic, healthy, and biopolitical light to a more acidic and tortuous and bitter one. Recruiters could lead to both polarities, but they contained the potential to transform themselves, and even

\footnotetext{
${ }^{1}$ Banaji, 'The Fictions of Free Labour', 74; Jairus Banaji, 'Modernizing the Historiography of Rural Labour: An Unwritten Agenda', in Companion to Historiography, ed. Michael Bentley (London: Routledge, 2006), 88-104, 89; see also Murray, “"Blackbirding” at "Crooks” Corner', 377, 397.
} 
reconfigure colonial societies and the experiences of those working in a colonial plantation island. Their singular power comes from their generative ambivalence, and it is a power that revealed the contradictions of imperial capitalism; they showed how the imperial contract was both compatible with unfree labour and incompatible with free labour. They exposed contradictions, which is to say, they proved colonial ideology wrong. They were effective in this mission, they did a "good job" so to say, but recruiters were of course neither part of the "good" or the "bad" end of the "freeunfree" labour spectrum. Were they then neither, or both? They were absolutely "grey"- but a thick heaving grey and continually added to compound-composed of both whites and blacks, containing both regressive and upwards spirals.

To recall the tripartite division of labour mobilization that Cooper makes in relation to South African touts, they seemed to largely reside and emerge from a third quality, "grey", the third non-pair of "the good, the bad and the ugly". Moral categories have a way to feed into aesthetic ones and invert them. The panorama, areas of operation and categories of experience of touts were beyond good and evil. ${ }^{2}$ Touts are a problem, sometimes to some of their victims, and other times to those who try to regulate them; their actions would be described in various moral keys as greedy, irresponsible, unreliable, or reprehensible. This profane quality is what makes touts also a conceptual problem. Touts cannot be approached or apprehended with binary thinking. Like in the profoundly dualistic triptychs of Hieronymus Bosch—The Garden of Earthly Delights, The Last Judgement - the images of hell are straight out of early modern lithographs depicting the techniques for terrorizing disobedient serfs and slaves, while paradise is, if not free labour, then primordial with the potential for liberation-Eve picking fruits at her leisure. Even for Bosch, the side panels are the most brutally familiar, from dreams and nightmares; everything 'interesting', fantastical yet real, happens in the broad central canvas that clearly defies labels. In the grand middle panels of Bosch's triptychs are horrendous and tantalizing scenes, depraved and lush, where bodies swim and fly with giant fruits; and fallen angels, who have shape-shifted into hybrid insectscavengers clumsily wielding blades and cleavers.

${ }^{2}$ Nietzsche, Beyond Good and Evil, 50. "Objection, evasion, joyous distrust, and love of irony are signs of health; everything absolute belongs to pathology". 
Recruiters - those quasi-strangers who are paid for their efforts - would clearly belong somewhere in the middle of the unfree-free labour spectrum, between perpetual and punctuated labour, between unpaid and paid by the day. On either end of the spectrum there are no recruiters. In theory, masters had the power of life and death over their conquered captives, which is what produces the status of the "slave" as permanent and unpaid labour. ${ }^{3}$ In unrecruited casual free labour, labour spontaneously and desperately self-assembles. Only the worker is paid or rather meagrely compensated after the task-exploitation in exchange. Touts and despots-labour contractors and variously armed bureaucrats - might in theory have withered away by themselves; their services of harassment and temptation coupled to direct compulsion were no longer necessary in the "transition" to "capitalist society". ${ }^{4}$ Yet when it came to recruiters, Spanish and other European colonials in the post-emancipation Atlantic worried about the radical commercialization of labour resulting from displacement: both the continuing wholesale purchase of people and of workers treating themselves as their own commodity. What "was at issue was not so much the capacity of market penetration to

${ }^{3}$ Orlando Patterson, Slavery and Social Death: A Comparative Study (Cambridge: Harvard University Press, 1982), 18-25.

\footnotetext{
${ }^{4}$ Much mostly worthwhile ink has been spilled in the key debates on "free and unfree" labour that flooded previous conjunctures of mostly Marxist theory. The debates can be briefly glossed as the Dobbvs-Sweezy, Finley-vs-the-classicists, Laclau-vs-Frank, Rudra-vs-Throner, Brenner-vs-the world, and a belated but essential and very insightful Banaji-vs-Brass battle. A lot would need to be cited. The debates can summarized as taking place between formalist or purists inspired by the late Marx (Gerald Cohen, Neil Brenner, Ernesto Laclau, etc.) and World-Systems Theory (Immanuel Wallerstein, Andre Gunder Frank, etc.) who were accused of conflating and stretching. Capitalists springing up wholesale under imperial land and labour laws were not as stringent in applying puritanical definition of free labour, whose two pillars, "free from" land and "free to" choose, are famous enough to never need to be repeated again. Marx, Capital, 171. For an overview, critique and overcoming of the debates see, Alice Thorner, 'Semi-Feudalism or Capitalism? Contemporary Debate on Classes and Modes of Production in India', Economic and Political Weekly 17, 59 (1982): 2061-66; Cooper et al., Confronting Historical Paradigms; Shahid Amin and Marcel van der Linden, eds., "Peripheral" Labour?: Studies in the History of Partial Proletarianization (Cambridge: Cambridge University Press, 1997), 1-9. Apart from the unfathomable, a person being stolen by another person, owned and treated purely as object and possession, as beast of burden and chattel, and the idyllic if the sometimes impoverished relief of really free labour, touts and despots appear as the makers of binds. Recruitment is the orchestrating, regulating and guaranteeing of an influx of those who did "not spontaneously offer their services at the place of employment." The Recruiting of Indigenous Workers Convention, no. 50 (Geneva, International Labour Office, 1936), Article 2. A more contemporary scene of this type of labour would be the waiting around on the roadside for construction contractors or farm work in California or Almeria. Though how this "dispensable" and indispensable migrant labour arrived at the roadside, through the advice of kin and people smugglers is not dissimilar to some historical recruiting assemblages under colonial rule. Or previous late Roman ones: "The labour market in the localized sense of a place where the hiring of labour occurred appears only rarely in ancient sources. Optatus in a famous passage refers to the nundinae where gangs of Circumcellions would usually hang out" waiting for odd-jobs. Banaji, Agrarian Change in Late Antiquity, 203.
} 
loosen workers from the land but an excess of commercialized labour mobilization, over which neither the planters nor the state was able to establish effective control."5

Unravelling the features of touts and despots in recruitment, of the market and the state, of Atlantic constellations and imperial formations, reveals a constant sequence of abrupt shifts, enabling, giving way and superseding each other: the colonial administration repeatedly engineers and retracts the onslaught of corvée, penal sanctions and vagrancy laws to shove people into contracts; recruiters appear and reappear in different guises once these laws are cast and recast; la recluta generates an unexpected lifeline for a new generation of Calabar middlemen trying to recoup the fortunes they lost to British monopoly-capital; but after mounting the largest labour trafficking network on the West African coast they lose their hold to ventures with touts at the forefront, who harness and radically realign an existing labour force; employers flood the market with escalating offers of credit and advances to new recruits to try to instil debt bondage, but these amounts actually become a pathetic pittance in the eyes of labourers who have in mind the rapidly inflating costs and expectations of life, so they outmanoeuvre pass-laws to pocket advances, deserting to other plantations and signing new contracts under false names in the process; the escalation of this simple underhand sign-on bonus relayed by touts threatens the island's plantations with implosion; guards, guards everywhere, yet they are completely unaware of the hideouts and pseudonyms of deserters, and are unable to distinguish a fake name on a fake contract because bribed functionaries have been handing out forms under the table. Timespans and paths coincide or radically diverge, free and unfree were side by side, separated only by a piece of paper, yet a doubling, an inconsistency - a forged contract, a renegotiation of unofficial advances_-could make everything invert or collapse.

A sustained attention on the ambivalent practices of recruiters reveals creative potentials for intensification and unravelling, rather than single points along a 'freeunfree' labour spectrum. The recruiters' presence was volatile. Touts did not simply reside in narrow bands of the grey areas, rather they could combine with others and push towards and redefine either extreme at varying times. The early twenty-firstcentury drift in the historiography seems to stagnate on the same realization that

\footnotetext{
${ }^{5}$ Sen, 'Commercial Recruiting and Informal Intermediation', 11.
} 
disturbed nineteenth-century abolitionists, some of whom also came to see contract labour along a foggy spectrum of slippages and resemblances, "along a very broad continuum rather than as a binary opposition. ${ }^{\prime 6}$ However if the actual operations and experiences of such blurs are taken into account a different, even more unstable but also more consistently crystallized, image appears.

\subsection{The Middle and End of the Spectrum}

The notion of a continuum or "spectrum" was analytically articulated in the writings of the classicists Moses Finley as well as Geoffrey de Ste. Croix, who more or less brought the term to bear in academic circles half a century ago. As notable Weberians and Marxists amongst the classicists, they engaged in old wrangles over "status" and "class", but in empirical practice they both shifted the attention of their colleagues from the "evils of slavery" arising from war and piracy towards "the evils of short-term tenancy under the harsh Roman law of debt" as well as "all sorts of other kinds of unfree labour" that existed in the first few millennia of empire "to a far greater extent, I think, than most classical scholars and even ancient historians have realised." Historians have long since peopled the expanded central canvas of the spectrum with what Finley called "involuntary" or "dependent" labour, which was "to a greater or lesser extent not free, a category for which our language provides no appropriate oneword label."7 Finley thought of the free-unfree range as "metaphorical, discontinuous

${ }^{6}$ Steinfeld, Coercion, Contract, and Free Labor, 8. For how non-historians have adopted this line see Stephanie Barrientos, Uma Kothari, and Nicola Phillips, 'Dynamics of Unfree Labour in the Contemporary Global Economy', The Journal of Development Studies 49, 8 (2013): 1037-41. Though in certain sectors of labour historiography the indisputable ingredients of free and unfree have remained analytically salient, always when decoupled from the arrow of modernity and the ready-made chart of history in two or three separate world. Arif Dirlik, Vinay Bahl, and Peter Gran, History After the Three Worlds: Post-Eurocentric Historiographies (London: Rowman \& Littlefield, 2000); Sabyasachi Bhattacharya, 'Labour Forms and International Labour Flows in the Context of North-South Relationship: An Overview', in The Long Twentieth Century: Globalization Under Hegemony, The Changing World Economy, ed. Kwame S. Jomo (New Delhi: Oxford University Press, 2006), 1-32.

${ }^{7}$ Finley, The Ancient Economy, 69, 65; Finley was trying to pluralize the debate: "we are the heirs of the Roman law, filtered through the Middle Ages, and we are mesmerized by the notion that at the lower end of the social scale, in the work force, there are three and only three possible categories, slaves, serfs and free wage-earners." Under "involuntary" Finley includes "everyone who worked for another not because of membership in the latter's family, as in a peasant household, and not because he had entered a voluntary, contractual agreement (whether for wages, honoraria or fees), but because he was bound to do so by some pre-condition, birth into a class of dependents or debt or capture or any other situation which, by law or custom, automatically removed some measure of his freedom of choice and action, usually for a long term or for life." 
spectrum, with gaps here, heavier concentrations there." Like in the spectrum of light itself when viewed through a prism, fringes emerge but "the difference among the primary colours remains perfectly visible." ${ }^{8}$ Finley uses the metaphor to show the overlaps of "colours" at the "fringes", while the spectrum itself can be as crisp as a rainbow, and be converted into a patchwork matrix. ${ }^{9}$ Colonial labour history has sometimes fallen into the traps provided by the metaphor of the spectrum. One of the effects of deploying such purified states and "status" categories is that static categories are foregrounded at the expense of complex transformations, inversions, and mutual imbrications - which often recruiters helped bring about. To bring the exhausted metaphor of the spectrum to its logical end: light only appears as a rainbow through a prism, an analytical lens so to say-a slightly psychedelic sun-dial which generates only an uninterrupted stream or continuum. The single prism cannot classify the way differences appear, extend themselves, become entrenched or unstable. The spectrum has been floated and bloated, but it needs to be shed, even exploded-not in any hostile way, my analytical metaphor might be something like a confetti canon or a clunky rectangular wheel with fireworks attached to propel its spokes.

In the historiography of modern empire with a neo- or post-Marxist agenda, the internal history of the expansion and accumulation of global capital transpires through a combination of free and unfree labour and everything in between. This decentralized scholarly output, now often gathered under the planetary but kaleidoscopic lens of Global Labour History, took a particularly rich turn around colonial and post-colonial South Asia and the post-emancipation Caribbean with the edited volumes of Brass,

${ }^{8}$ Finley, The Ancient Economy, 65.

${ }^{9}$ Whose coherence is always incomplete-partly because the radical third dimension of recruiters never
appears. The word recruiter does not appear even once-except when conflated with "labor bosses" who
were "recruiters and managers of labour" in China, and as state-run agencies for exporting domestic
workers in Indonesia-in the almost thousand pages of Jan Lucassen, ed., Global Labour History: A
State of the Art (Bern: Peter Lang, 2008), 381, 502; For varied matrices, see Jan Lucassen and Leo
Lucassen, Migration, Migration History, History: Old Paradigms and New Perspectives (Bern: Peter
Lang, 1997); Van der Linden, Workers of the World; 'The Global Collaboratory on the History of Labour
Relations 1500-2000', available at https://collab.iisg.nl/web/labourrelations; also Karin Hofmeester, Jan
Lucassen and Filipa Ribeiro da Silva, 'No Global Labor History without Africa: Reciprocal Comparison
and Beyond', History in Africa, 41 (2014), 249-76. For hyper-formalized but extremely elegant table,
see the appendix in Moulier Boutang, De l'esclavage au salariat. Matrices are always provisionally
insightful, but Sisyphean in the face of living labour, infinite toil and creativity through millennia and
continents. 
Breman, Bhattacharya, Behal, Van der Linden and others. ${ }^{10}$ In the past two decades GLH has taken the centre stage of a social history tasked with setting the records straight, with redistributing the history of capitalism by reconfiguring the hangover and remnant of a two-point, linear and progressive timeline. ${ }^{11}$ It is in the broad middle of semi-free or partially unfree from where the continuous crossovers and recurring stratagems of empire and capital have been revealed. As Alessandro Stanziani says in relation to the colonial Indian ocean, this middle contains and combines a "variety of forms of debt bondage, indenture contract, and other forms of bondage contracts between [masters and coolies], as well as genuine slavery." ${ }^{12}$ But where do the recruiters fit?

They are ambivalent and creative agents who insert themselves with actions and effects that deflect the either/or. It is through them that we can finally expand our vocabulary. Recruiters cannot be disentangled and shoved into a matrix. In a historical terrain, the recruiters in the middle of the spectrum, their tendencies and entanglement, were thoroughly unpredictable; touts were free to go either way, they could deploy the same tools and become quasi-slave-traders or their exact opposite. Touts harnessed and confounded their own potentials. They were rather a series of thick twisted strokes that could feed into the experience of binary pairs, the experience of enslavement and the experience of reclaiming freedom, a disturbing background noise whose actions took place behind a legal optic or an institutionalized definition of status.

\footnotetext{
${ }^{10}$ Tom Brass and Marcel van der Linden, eds., Free and Unfree Labour: The Debate Continues (New York: Peter Lang, 1997); Rana P. Behal and Marcel van der Linden, eds., Coolies, Capital, and Colonialism: Studies in Indian Labour History (Cambridge: Cambridge University Press, 2006); Jan Breman, Isabelle Guérin, and Aseem Prakash, India's Unfree Workforce: Of Bondage Old and New (New Delhi: Oxford University Press, 2009); Mohan Rao, 'Freedom, Equality, Property and Bentham: The Debate Over Unfree Labour', The Journal of Peasant Studies 27, 1 (1999): 97-127.

${ }^{11}$ Chakrabarty, 'Postcoloniality and the Artifice of History'; Jack Goody, The Theft of History (Cambridge: Cambridge University Press, 2007).

${ }^{12}$ Alessandro Stanziani, Labour, Coercion, and Economic Growth in Eurasia, 17th-20th Centuries (Leiden: Brill, 2012), 1-28, 4; foundational in this middle of the spectrum are Willemina Kloosterboer, Involuntary Labour since the Abolition of Slavery: A Survey of Compulsory Labour throughout the World (Leiden: Brill, 1960), pages 167-8 are on Liberia-Fernando Pó; Tinker, A New System of Slavery; Anthony Reid and Jennifer Brewster, Slavery, Bondage, and Dependency in Southeast Asia (New York: St. Martin's Press, 1983); cf. Brij V. Lal, 'Indian Indenture Historiography: A Note on Problems, Sources and Methods', Pacific Studies 6, 2 (1983): 33-50.
} 
After looking at the activities of the touts in and around Fernando Pó I had to conclude that the metaphor of the spectrum simply does not hold: the same contract generated opposites and more. Contracts were bondage contracts, with their own bounded consistency, which nevertheless generated wildly disparate modalities of recruitment. The same contracts, the same recruiters, the same workers combining in and altering their own assemblages, lead to vastly different outcomes. In one constellation recruiters allowed the island's cacao plantations to flourish on the backs of an unprecedented influx of quasi-kidnapped people in the late 1930s and 1940s, and in the next step, a lot of these same recruits combined again, quite willingly, with recruiters and together they almost collapsed the economy of the island by escalating dashes and desertions.

\subsection{Main Results: Touts Blur the Line with Panya and Dash}

In a sense it is cheating to evoke the dichotomy of free and unfree labour, as there was no dividing line in Fernando Pó: once on the island, work contracts were obligatory, the strangely constant small print of these obligatory contracts were pre-set by the colonial printing press. "Unemployment is not known here. In fact, there are regulations for compulsory employment - any person who failed to produce satisfactory evidence of being in employment is arrested and detained." ${ }^{13}$ However the contract could be both rigid and flexible resulting in various prefigurations and consequences. This template of colonial capitalist labour control was nevertheless the only thing that kept recruitment — in all its different combinations - going. However, the radically different experience and circumstance of entering a contract at quasi-gunpoint or propelled through one's own entanglements produced a set of touts that had their own transversal direction in the spectrum. The contract on Fernando Pó was not a discrete unit, in spite of its formal print and assumed conditions of a rupture with slavery, it contained slavery and autonomy, a veil for brutal coercion and the unintended avenue for a radical and self-determined escalation that allowed workers to achieve the status of 'free' labour or at least to receive the total wages of what a 'free labourer' would have been able to bargain for.

\footnotetext{
${ }^{13}$ British VC (Harriman), 22 April 1960, ‘Annual Report 1959/60’, TNA, FO 371/146562.
} 
If we start from the lived circumstances of entering the contract rather than from the non-possibility of exiting a contract - a common defining marker of unfree waged labour ${ }^{14}$ - then the panorama, the spectrum, can sometimes quickly coagulate back into two. The radically different effects of touts - a divide marked by wilful entanglement and the potentials for creative redeployments - is why a divide between free or unfree holds up; a difference defined by workers' strategies and revisable states of mind, and not by categorical preconditions or status. The indentured contract was not part of a step-wise linear trajectory but led to these contradictions, folds, and surprises spurred on by creative redeployments of the 'Afro-European' practices of dash and panyarring.

Touts radically distorted the usual narrative of "free" and "unfree" labour, through a kind of uncontrolled fusion and fissioning. It is through them we can rethink and even abandon notions of institutionalized "free labour" and categorical legal or status-based definition of unfree labour-i.e. if there was a contract it was contract labour, everything else, and particularly the extremes are their own categories with their own sets of preconditions that no one can trample on or rewrite. Braceros did not hesitate in denoting their experience as a kind of enslavement, when faced by the fact that they were being sold and effectively working for free, at least during the first contract. The contracts of panya, allowed the randomness and violence of panyarring, as dialecticians would say, to be 'sublated' or eliminated/preserved, carried on almost purely through the broken prism of language on the one end, the West African coast, while on the other end the plantations remained unaltered. Touts also reveal a 'truth' about the proper constitution of 'free labour', and rendered the marriage of liberal ideology and imperial capitalism explosively contradictory if not fully incompatible.

In the nineteenth century, touts, like the other informal brokers who had unsystematically and clandestinely been organizing most "indenture" labour migration, at least during what David Northrup calls the "early phase", ${ }^{15}$ started to be a considered

\footnotetext{
${ }^{14}$ Tom Brass has conceptually brought together slave colonies, vagrancy ordinances, share cropping, penal colonies, indentured labour and even the realities of paperless immigrants under one category, unfree, which is only held together by using the definition of non-exit from 'contract' or bondage which eliminates "the capacity personally to recommodify their labour-power," selectively citing Marx when he says that free labour as "untrammeled" self-ownership "must constantly treat his labour-power as his own property, his own commodity." Brass, "Why Unfree Labour is not "so-called"; Marx, Capital, 271, 171.
}

${ }^{15}$ Northrup, Indentured Labor in the Age of Imperialism, 6. 
a disturbance, an interference, an impediment to the smooth-flowing but highly regulated "free" movement of people whose rational arrival at their destination as proper "capitalist" workers was imaged to be the retroactive result of a transparent and informed displacement, requiring both the state-surveyed infrastructures of registration and explanation and the ideological ideal of a self-sovereign subject. While reading through the ILO's Forced Labour Convention of 1930, Juan Bravo, the leading colonial ideologue, pondered why the concept of "voluntary" seemed to him to "be inadequate: after all if we do not incline the indigena to work by deploying dadivas o con alguna palabreria de una poca fantasia"_- "presents/advances or hot air with a dose of fantasy"-_ "he will never offer us his brazos" his arms. ${ }^{16}$ Amongst more liberal-minded colonial Spaniards and certainly in the policy doctrines of the late British colonial mind, the idea also roamed that ideally the decision to move and take up a contract was to be made without undue influences or duress coming from stranger-brokers or even from over-bearing family members. In Nigeria with the Labour Ordinance No. 1 of 1929, like in other colonial territories, legal means were brought in to prohibit recruitment and license emigration to "ensure that illiterate or inexperienced men were safeguarded against rapacious employers, traders and others." ${ }^{17}$ Their impulse was to 'de-victimize' indentured labour recruitment by removing randomness and innocence, though this by itself did not lead to less exploitative working conditions.

Attempts by the British through the 1942 labour treaty to create a paper trail for the declarations of consent were a way to have labour movements and relations be in conformity with the laws of exchange and self-interest. It was a bureaucratic mechanism that would disenchant the labour market through a congruent arrangement of expectations and realities, in order to make its brutal realities and disappointments appear legitimate. Even the most formal and properly conducted of contract was a way for employers to be simply legitimated in their exploitation. They continued their

\footnotetext{
${ }^{16}$ Bravo Carbonell, 'De la Guinea española: El trabajo indígena', El Sol, Barcelona, 3 June 1930.

${ }^{17}$ Nigerian Secretariat, Lagos, [undated, 1953] 'Memorandum', RHL, 600.18 s. 21/XI (10). "The ordinance was specifically targeted at Spanish Guinea's labor trade, the notoriety of which was becoming well known in the 1920s". Aworawo, 'Decisive Thaw', 93. In Nigeria "no native may accept [foreign contracts] without the sanction of an administrative officer (penalty, a fine of $£ 25$ and/or three months' imprisonment). The administrative officer must satisfy himself that the native is fit to work, is over the age of 16, is not abandoning any dependent relatives, and is not absconding to avoid liability under native law". Orde Browne, The African Labourer, 154.
} 
plantation regime under practically unaltered conditions of work, the effective perpetuation of the same colonial plantation. The colonial plantation island required a certain set of contractual templates and vagrancy ordinances to sustain itself, its order and productivity. The order of this same colonial plantation was the same one that allowed touts to flourish in the first place. Touts reveal the creative role that the imperial state and capitalism had in "constituting bondage", and challenges the ideology that "presents servitude as a condition outside its field of operation, as a form of social existence identifiable and analysable as alien and opposed to capitalism." 18

In the dash chapter, I argued that in semi-anonymous imperial contexts the wage advance did not generate domination and immobility; exactly the opposite, they produced unprecedented waves of further escalation and dispersed flight. The dash was pushed up by workers themselves and relayed by informal resident recruiters. Together they turned this lynchpin of indentured labour and debt peonage into a counter-practice that almost led to the collapse of the plantations in the 1950s. The conclusion that can be made through the dash is that the history of freedom resides beyond the terrain of the compliance and procedures of "free" labour. The dash was generated wholly on the side of the workers and the touts themselves, and produced a free movement aiming at improved rights and stakes on the island, that were totally outside the coordinates of state-issued legalisms. In fact, the trajectories of the dash can lead to a more pointed version of the foundational thesis of Global Labour History, namely that it was actually free labour, not unfree labour, that was incompatible with imperial capitalism. ${ }^{19}$

\footnotetext{
${ }^{18}$ Prakash, 'Colonialism, Capitalism and the Discourse of Freedom', 10; also conclusion of his Bonded Histories; for a critique see Bhattacharya, Labouring Histories, 14-9; and a sympathetic review, see van Schendel, 'Stretching Labour Historiography: Pointers from South Asia', 233-4. This is also Banajis main critique against Brass. Even if the freest of free labour should be "based on the 'consent' of the individual worker and the free bargain that embodies that "consent", to oppose it to "unfree labour" ignores "contract law's role in making actual domination appear free, natural, and rational". Banaji, 'The Fictions of Free Labour', 74.

${ }^{19}$ Not only is it "the combination of free and 'unfree' labor and land that in fact characterizes the capitalist world-economy". Wallerstein, The Capitalist World-Economy, 149. World-Systems abundantly pointed out the ubiquity of serfdom, forms of unfree labour, etc, but the obvious conclusion is that it was capitalism itself that is incompatible with free labour, and not only in situations of labour scarcity. The most thorough historical argument that bureaucratic capitalism engenders borders, divisions, and violence, blocking or succumbing in its attempts to block the freedom of movement of labour power, is Moulier Boutang, De l'esclavage au salariat, whose argument is that it would be not just that the eliminating of "unfree production relations would in effect knock away the bottom rungs of the ladder that is the capitalist labour regime" but the entire thing. Brass 'Debating Capitalist Dynamics and Unfree Labour', 577.
} 
Plantations would have immediately collapsed, been run to the ground, capital would have dug its own grave if anything like negotiated wages - as well as the ability to withdraw from a contract-would have played out in the "scarcity". As Ibrahim Sundiata has reasonably surmised: already in the 1890 s "voluntary labor migration became increasingly difficult to maintain; given a free play of forces, plantation agriculture on the island would have probably collapsed." ${ }^{20}$ Free labour was not more expensive; it simply was not an option if capital wanted to subsist. ${ }^{21}$

The contract accommodated and induced much else besides the forced subjection or voluntary submission into temporary bondage. The contract could be a device for economically productive torture of kidnapped victims or an elective moment in the life of people who signed up not because of the wage, but because of the ancillary wageadvances mediated by touts. The central plate of the contrato on the plantation island could shift in different directions, enabling the recruitment of unwilling captives as well as consenting beings, and indeed be spun out of joint completely by the latter. As soon as there was any semblance of agents pushing through their demands - always with the help of touts - everything changed. This instability was barely perceptible on the surface of the colonial order of contract things. Free and unfree recruitment cannot be read off from the contract, neither from a kind of unchanged essence inherent in it nor from its precisely worded letters. A history of free and unfree labour cannot anchor itself in the terms of contract: the contract 'was this and this long', wages were 'so and so low', it was 'signed', 'attested', etc.: “All of this is a poetics ably written on paper,

\footnotetext{
${ }^{20}$ Sundiata, 'The Rise and Decline of Kru Power', 38.

${ }^{21}$ Neoclassical labour economics have noticed the same things of course: Coercion they say "is mainly about forcing workers to accept employment, or terms of employment, that they would otherwise reject," Of contracted labour and coercion and "guns", they say: "we assume that $\mathrm{c}(0)=0$ and that $\mathrm{c}(\cdot)$ is strictly increasing, strictly convex, and twice differentiable, with derivative denoted by c', and we also impose that lima $\rightarrow 1 \mathrm{c}(\mathrm{a})=\infty$ to ensure interior solutions. Suppose that the market price for the output of the producer is $\mathrm{P}$. Thus when the agent accepts contract (wy, py) and chooses effort a, guns are equal to $\mathrm{g}$, and output realization is y, the producer's payoff is Pywy [...] $\{\mathrm{g}$ )”. Daron Acemoglu and Alexander Wolitzky, 'The Economics of Labor Coercion', Econometrica 79, 2 (2011): 555-600, 555, 557, 561. You don't need a model to tell you this: "Our model also explains the more puzzling phenomenon, the almost complete reluctance to use free (non- indentured), wage labor, right to the end." "The wage rate could not be consensual, even if effort were observable, because the units were not in competitive equilibrium in this labor market." Steve De Castro, 'Modern Slave Plantations to Firms and Labor Markets: Incentive Theory for a Growth Disaster', in Programa de Seminários Acadêmicos (Instituto de Ciências Humanas Departamento de Economia, Universidade de Brasília, 2001), 6. All of this new labour economics is inspired by the classic text of Shapiro and Stiglitz, 'Equilibrium Unemployment as a Worker Disciplinary Device'.
} 
but none of it occurs in our colony." 22 There is not much to gain by asking whether the contracts themselves were technically free or unfree or semi-unfree. Depending on the circumstances the contract could make way to either one, even in their quasi-purest form.

The political economy of contracts within a labour scarcity was weaved and laced with autonomous intermediaries that could contradict-add loop-holes and shortcuts-and cause the entire "economic force" to, alternatingly, intensify or crumble. Recruiters could surprise the imperial economics of labour demands; they could collide and jam the force of an entire agro-capitalist plantation island and make it collapse onto itself. If "the word 'force' appears too mechanical or too bellicose, then we can talk of weakness", ${ }^{23}$ of constant decomposition and provisional patches, the only thing holding things up in Fernando Pó was in times of the "scarcity" crisis, a single screw, the contract. They compromised channels, found its weakest link and made visible the foundations and inconsistency of a colonial capitalist mode of production that had tried to distance itself from slavery and issue the false inauguration of the era of free labour. Touts could be collaborating agents of planters' productivity or transgressive mediums of excess.

\subsection{Wider Conclusions: Trafficking and People Smuggling Today}

Present on Fernando Pó was a bridge that linked the (dis)continuities between the abolition and the slave trade and the range of new techniques often found in what would today be called human trafficking and people smuggling. These labels are a way to superimpose social and political meaning to a "crime"; to pile up and aggregate a range of mediators into the "unfree" blur range of the spectrum. As the historian Adam McKeown says in his study of indenture migration movements in Asia the "stark dichotomy" of free and unfree emerged from the African slave trade, "yet here were these new types of 'slave-traders' who were being mobilized to informally recruit indentured labour." These brokers were being "excluded from the management of mobility", and while they were being "pushed underground", they found new

\footnotetext{
${ }^{22}$ Babiloni Navarro, 'Los territorios españoles', AGA, C-81/12427.

${ }^{23}$ Latour, The Pasteurization of France, 155.
} 
opportunities and techniques between and beyond "legal jurisdictions and frameworks." 24 These brokers continue to accompany us today. The labels "trafficker" and "people smugglers" continue to demonize brokers today, the media, politicians and activist use images and vocabulary that can be traced back, as McKeown shows, to nineteenth century debates over indenture.

My dissertation has been situated in this context, and has aimed to show how these brokers were actually very ambivalent, just as they are today. It is with this ambivalence and volatility that I think we need to view contemporary forms of labour trafficking and human smuggling through. Touts, who have always been with us, are still here, in some busy places at the discordant junctions of unregulated supply and excess demand, they are everywhere. In the colonial period, they became a medium to explode the contradictions of colonial plantation - the contract and the regulated wage - and similarly today in our own form of bureaucratic capitalism, they open borders where these have been closed, they promise too much money and hope and they engender further contradictions.

Last but not least, an attention to the type of touts whose movements, techniques and destinations I have been tracing, reveals a wider conclusion: something along the lines that capitalist exploitation of unfree labour works not through them but through the templates provided in the last instance by forms of state power. This capacity to become a medium, a medium that retains its ambivalence if circumstances change, provides credence to more recent critiques of the notion of "human trafficking" and the (mis)representation of its victims. While sociologists often speak in terms of choice and risk, assuming an individualistic configuration of personhood, they highlight the importance of accepting the migrants' own nuanced gradients of dysphoria and transport needs, their assessment and acceptance of the opaque and unpredictable logistics of illicit brokers. It is touts who have the means and know-how to "assist" in the unauthorized emigration to destinations with a labour market, where migrants may or may not experience or expect severe coercion at the hands of disciplinarian employers or the punitive state-on Fernando Pó they certainly did if they refused

\footnotetext{
${ }^{24}$ McKeown, 'How the Box became Black', 22.
} 
work or wanted to change employer or return home before the expiration of the contract. $^{25}$

The exercise of underlining the conditions set up by the colonial state that made recruitment possible is a way to give historical clout to the critique of the present; to find historical tools to critique contemporary political frames that either try to blame "gullible victims" or informal brokers for entrapping people into situations of exploitation. The critical literature on contemporary forms of human smuggling and unfree labour has argued and demonstrated that the creation of vulnerable, precarious and trafficked labour across border works largely within the interstices of state, rather than in the domain of the irresponsible organized crime of an autonomous underground. On the one hand this is either because officials are bribed or do not conduct inspections, or even if they weren't or did, "informally" exploited labour cannot readily get out of their predicament because they would land in the hands of state agents. These state agents may provide for even worse conditions of torture, and the beatings and deprivations of prison can be followed by deportation and bankruptcy. As I showed in the dash chapter, when braceros complained that employers were using the dash to try to forcibly extend their contracts, Llompart Aulet, the Curador, did not hesitate to confine braceros and confiscate their dash and deport them for negotiating a wage that would have retroactively compensated their first few years of largely unpaid labour.

Recruiters usually get a bad press and a rap sheet worthy of corporate criminals. Those arguing against indenture - both contemporaries and academics-obviously "mistrusted the ability" of "labor recruiters, tainted by the history of slavery, to be agents of emancipation." ${ }^{26}$ But this is only because touts have been conflated with despots, something the braceros themselves never did. Asking any of the labourers on Fernando Pó, they would have told you that there is a world of difference between solicitation and conscription, between responding to an inquiry and a beating, between sceptical and uncertain alliances and imposed and fateful filiation. The tout lodged him or herself (many were women) as an external medium to people's concrete desire to

\footnotetext{
${ }^{25}$ Julia O’Connell Davidson, Modern Slavery: The Margins of Freedom (New York: Palgrave Macmillan, 2015), 111-2. On the non-possibility of exiting a contract as the common defining marker of unfree waged labour, see Brass, 'Why Unfree Labour is not "so-called"'.

${ }^{26}$ McKeown, Melancholy Order, 70.
} 
navigate and profit from a growing un/known world. The tout was an always to be found medium, a dispensary of wealth, in the whirl of Fernando Pó's boastful commercial demands. The despot only intermittently bursts onto the scene, recedes and constantly threatens to return. Entire political formations have been built on threats and small groups of armed subordinates. Touts do not seem very formidable in comparison; but they were. 


\section{Archives and Primary Sources}

- A spreadsheet for each archive with a detailed breakdown of the archival boxes and files that I consulted is available.

- Abbreviations: For a full breakdown of dates and the full names of officers and varying bureaucratic designations, I have a spreadsheet: 'Abbreviations and Proper Names: DGMC, GG, SubGG, Curaduria, Camara, British VC, etc.'

\section{AGA = Archivo General de la Administración, Alcalá de Henares, Spain}

IDD 15 Fondo África

IDD 15.004: Ministerio de Asuntos Exteriores Sección Colonias; Ministerio de la Presidencia del Gobierno: Actuación en Guinea, 1905-1986

IDD 15.005: Ministerio de la Presidencia del Gobierno, 1905-1986

IDD 15.006: Ministerio de la Presidencia del Gobierno, 1901-1985; Gobierno General de Guinea, 1925-1961

IDD 15.018: Comisaría General de Guinea, 1911-1969; Gobierno General de Guinea, 1804-1969; Ministerio de la Presidencia del Gobierno, 1951-1969; Tribunal de la Demarcación Este de Guinea Ecuatorial (Distrito de Fernando Poo), 1939-1962

81/06257; [..]; 81/06261; [...]; 81/06265; [..]; 81/06270; [..]; 81/06273; [...]; 81/06276; [...]; 81/06412; 81/06413; 81/06414; 81/06415; $81 / 06416 ; 81 / 06417 ; 81 / 06418 ; 81 / 06419 ; 81 / 06420 ; 81 / 06421$; $81 / 06422 ; 81 / 06423 ; 81 / 06424 ; 81 / 06425 ; 81 / 06426 ; 81 / 06427$; [..]; $81 / 06433 ;[\ldots]$; 81/06444; 81/06445;81/06446; [...];81/06453; [...]; $81 / 06461 ; 81 / 06462 ; 81 / 06463 ; 81 / 06464 ; 81 / 06465 ; 81 / 06466$; 81/06467; [..]; 81/06527; [...]; 81/06476; [...]; 81/6561; [..]; 81/06718; $81 / 06719 ;[\ldots] ; 81 / 06722 ; 81 / 06723 ;[\ldots] ; 81 / 06730 ;[\ldots] ; 81 / 06808 ;[\ldots]$; $81 / 06843 ; 81 / 06844 ; 81 / 06845 ; 81 / 06846 ; 81 / 06847 ; 81 / 06848$; $81 / 06849 ; \quad 81 / 06850 ; \quad 81 / 06851 ; 81 / 06852 ; 81 / 06853 ; 81 / 06854$; 81/06855; 81/06856; 81/06857; 81/06858; 81/06859; [...]; 81/06864; 
$81 / 06865 ; 81 / 06866 ; 81 / 06867 ; 81 / 06868 ; 81 / 06869 ; 81 / 06870 ;[\ldots]$; 81/06903; [...]; 81/06931; [...]; 81/06939; [...];81/06944; 81/06945; [...]; 81/07056; [..]; 81/07124; [..]; 81/07141; [...];81/07176; 81/07177; [...]; 81/07180; [...]; 81/07193; 81/07194; 81/07195; 81/07196; 81/07197; 81/07198; 81/07199; 81/07200; 81/07201; 81/07202; 81/07203; $81 / 07204 ; 81 / 07205 ;$ [..]; 81/07633;81/07634; [...];81/07646; [...]; $81 / 07717 ; 81 / 07718 ; 81 / 07719 ; 81 / 07720 ; 81 / 07721 ; 81 / 07722$; 81/07723; [...]; 81/07785; 81/07786; [...]; 81/07789; 81/07790; $81 / 07791 ;$ [..]; 81/07796; 81/07797; 81/07798; [..]; 81/07848; [...]; $81 / 07908 ;[\ldots] ; 81 / 07957 ;[\ldots] ; 81 / 07963 ;$ [..]; 81/07967; [...]; 81/07992; [..]; 81/08028; [..]; 81/08055; 81/08056; [...]; 81/08063; $81 / 08064 ; 81 / 08065 ; \quad[\ldots] ; 81 / 08081 ; \quad[\ldots] ; 81 / 08094 ; 81 / 08095$; 81/08096; 81/08097; 81/08098; 81/08099; 81/08100; [...]; 81/08125; $81 / 08126 ; 81 / 08127 ; 81 / 08128 ; 81 / 08129 ; 81 / 08130 ; 81 / 08131$; 81/08132; 81/08133; 81/08134; 81/08135; 81/08136; 81/08137; 81/08138; [...]; 81/08144; 81/08145; 81/08146; 81/08147; 81/08148; 81/08149; 81/08150; 81/08151; 81/08152; 81/08153; 81/08154; 81/08155; 81/08156; 81/08157; 81/08158; 81/08159; 81/08160; $81 / 08161 ; 81 / 08162 ; 81 / 08163 ; 81 / 08164 ; 81 / 08165 ; 81 / 08166 ;[\ldots]$; 81/08175; 81/08176; 81/08177; 81/08178; 81/08179; 81/08180; $81 / 08181 ; 81 / 08182 ; 81 / 08183 ; 81 / 08184 ; 81 / 08185 ; 81 / 08186$; [...]; 81/08194; 81/08195; [...]; 81/08213;81/08214; 81/08215;81/08216; [...]; 81/08223; [...]; 81/08526; 81/08527; [...]; 81/08535; [...]; 81/08545; [...]; 81/08601; 81/08602; [..]; 81/08621;81/08622; [...]; 81/08667; $81 / 08668 ; 81 / 08669 ;[\ldots] ; 81 / 08691 ;[\ldots]$; 81/08696; [...]; 81/08701; 81/08702; [...]; 81/08771; 81/08772; 81/08773; 81/08774; 81/08775; $81 / 08776 ; \quad 81 / 08777 ; \quad$ [...]; 81/08781; 81/08782; [..]; 81/08802; $81 / 08803 ; 81 / 08804 ; 81 / 08805 ; 81 / 08806 ; \quad[\ldots] ; 88 / 08819 ; \quad[\ldots]$; 81/08827; [...]; 81/08882; [..]; 81/08895; [...]; 81/08935; [...]; 81/08938;

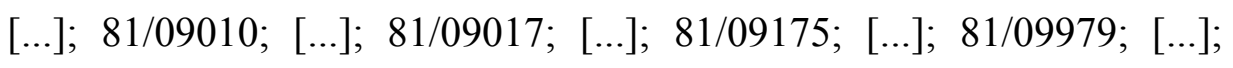
$81 / 10942$; [...]; ;81/11053; [..]; 81/11082; [..]; 81/11524; 81/11525; $81 / 11526 ; 81 / 11527 ; 81 / 11528 ; 81 / 11529 ; \quad$ [..]; 81/11717; [...]; $81 / 11844 ; \quad[\ldots] ; \quad 81 / 11849 ; 81 / 11850 ; 81 / 11851 ; 81 / 11852 ; \quad[\ldots] ;$ 81/12095; [...]; 81/12300; [...]; 81/12373; [...]; 81/12408; [...]; 81/12422; 
[..]; 81/12426; 81/12427; ; [..]; 81/12782; [..]; 81/12894; [..]; 81/13037; [..]; 81/13039; [...]; 81/15865; [..]; 81/17137; [...]; 81/17700; [...]; 81/17764; [...]; 81/17770; 81/17771; 81/17772.

Abbreviations: C-; L-; E- = Caja; Legajo; Expediente (Box; Bundle; File). Sometimes there are no legajos or expedientes, just a pile of 'emic' original bundles totalling 5000 individual sheets of paper per Caja; sometimes the 'emic' expedientes are roughly chronological, for example 'Curaduria, 1944', other times there are etic or extraneously catalogued, roughly thematic, brown files with numbered expedientes but no title).

\section{AGS = Archivo General de Indias, Sevilla, Spain}

Consejo de Estado

Legajo 7411.

\section{AMAE $=$ Archivo General del Ministerio de Asuntos Exteriores y de Cooperación, Madrid, Spain}

H Archivo Historico

R Archivo Renovado

TR Archivo Historico. Tratados

H 2891; H 3050 E-021; H 3102; H 3102; R.176 E-4; R 447 E-20; R 470

E-14; R 735 E-4; R 757 E-13; R 802 E-8; R 815 E-3; R 887 E-33; R 887 E-52; R 887 E-62; TR 439 E-012; TR 583.

\section{ANCB = Archivo Nacional de Cataluña, Sant Cugat del Vallés, Spain}

Fons 237 Casa de la Guinea Ecuatorial

Caja 1; Caja 2; Caja 5; Caja 10. 
ANC $=$ Archives Nationales du Cameroun, Yaoundé, Cameroon

APA Affaires Politique et Administrative

APA 10165/A; APA 10165/B; APA 10165/C; APA 10222; APA 10225;

APA 10908/B; APA 11805/A; APA.11805/E.

ANG = Arches Nationales de Gabon, Libreville, Gabon.

Gouvernement, Les papiers du Haut-Commissariat, Wolé-Ntem, Oyem: Région du Wolé-Ntem, Rapports périodiques.

ANOM = Archives Nationales d'outre-mer, Aix-en-Provence, France

FR ANOM Ministère des Colonies. Délégation du Cameroun et du Togo

FR ANOM 110COL940/3033-3036; FR ANOM 61COL354; FR ANOM 61COL363; FR ANOM DPCT57.

\section{BACL $=$ Biblioteca Africanista del Colegio Claret, Luba, Equatrial Guinea \\ Personal Archives Missionaries (Carpeta Roja de Botones) [no index]}

BArch $=$ Bundesarchiv Lichterfelde, Berlin, Germany

NS 5 VI Deutsche Arbeitsfront / Arbeitswissenschaftliches Institut

NS 52 Kolonialpolitisches Amt der NSDAP

R 2 Reichsfinanzministerium

R 901 Auswärtiges Amt

R 1001 Reichstkolonialamt

NS 5 VI / 1234788 B428; R 2/4989; R 901/6591; R 901/26743; R 1001/3234; R 1001/3504; R 1001/3765; R 1001/3766; R 1001/8005; R 1001/9515. 
BMA = Basel Mission Archives, Basel, Switzerland

Kamerun

E-02.13; E-02.14; BMA E-02.15; [...] E-02.37; E-02.38.

BNA = Buea National Archives, Buea, Cameroon

QD Cameroon Development Corporation

QE Provincial Office, Buea

Qe(1933)5; Qd/a (1947).

BNE = Biblioteca Nacional de España, Madrid, Spain

Mss Biblioteca del Ministerio de Ultramar

AFRC Africa, Cajas Folletos, Salon General

D Sala de Prensa y Revistas

AFRMPS África Mapas, Sala Goya

Mss/13850; AFRC/7101/12; BN AFRC/7101/14; AFRMPS/1/04; AFRMPS/1/08; AFRMPS/20/1017.

\section{BNM = Biblioteca Nacional de Guinea Ecuatorial, Malabo, Equatorial Guinea}

Colección de Erika Reuss y otras adquisiciones, no index, but unique holdings such as:

Map: ‘Ile de Fernando Põo’, 1901.

Policía Gubernativa, Santa Isabel, 'Registro de Incidencias 1953'.

Partido Unico Nacional, 'Formacion Politica Anticolonial' (Santa Isabel:

Diario de la Guinea Ecuatorial, 1971). 
Union Revolucionaria de Guinea Ecuatorial and Akomamba, 'Una Alternativa Socialistas Para Guinea' (n.p, 1976).

LON = League of Nations Archives, Geneva, Switzerland

VI.B Slavery

C.658.M.272

LSE $=$ Archives Division, London School of Economics, London, UK

IAI International African Institute

IAI/25/24; IAI/25/25; IAI/25/27.

NAC $=$ National Archives of Nigeria, Calabar

CADIST Calabar District Office

CADIST 3/3/324; CADIST 3/3/484; CADIST 13/1/13; CADIST 13/1/286; CADIST 13/1/292; CADIST 13/1/414; CADIST 13/1/415.

NAE $=$ National Archives of Nigeria, Enugu

ABADIST Aba District Office

ABAKDIST Abak District Office

ARODIV Arochukwu Divisional Office

AWDIST Awka District Office

CALPROF Calabar Provincial Office

CSE Civil Secretary, Enugu

EKETDIST Eket District Office 
IKOTDIST Ikot Ekpene District Office

OBUDIST Obudu District Office

ONDIST Onitsha District Office

OPODIST Opobo District Office

RIVPROF Owerri and Rivers Provincial Office

ABADIST 1/26/907; ABADIST 14/1/137; ABADIST 14/1/853; [...]; ABADIST 14/1/875; [...]; ABAKDIST 1/2/76; ABAKDIST 1/2/77; [...]; ARODIV 3/1/36; [...]; ARODIV 19/1/44; [...]; AWDIST 2/1/330; [...]; CALPROF 3/1/1447; [...]; CALPROF 3/1/1623; [...]; CALPROF

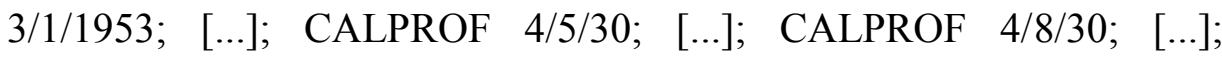
CALPROF 5/1/192; CALPROF 5/1/193; CALPROF 5/1/194; CALPROF 5/1/195; [...]; CALPROF 5/1/315; CALPROF 5/1/316; CALPROF 5/1/317; CALPROF 5/1/318; [...]; CALPROF 7/1/457; CALPROF 7/1/458; CALPROF 7/1/459; CALPROF 7/1/460; CALPROF 7/1/461; CALPROF 7/1/462; CALPROF 7/1/463; CALPROF 7/1/464; CALPROF 7/1/465; CALPROF 7/1/466; [...]; CALPROF 7/1/474; CALPROF 7/1/475; CALPROF 7/1/476; [...]; CALPROF 7/1/1651; [...]; CALPROF 17/1/277; CALPROF 17/1/278; CALPROF 17/1/279; [...]; CALPROF 53/1/553; [...]; CSE 1/85/5122; [...]; CSE 5/7/30; [...]; CSE 9/1/6; [...]; EKETDIST 1/2/65; EKETDIST 1/2/14/6; [...]; IKOTDIST 14/1/44; [...]; OBUDIST 4/1/348; [...]; ONDIST 12/1/280; ONDIST 12/1/281; ; OPODIST 1/1/36; OPODIST 1/1/37; OPODIST 1/1/38; [...]; RIVPROF 2/1/53; RIVPROF 9/1/135; [...]; RIVPROF 2/1/58; [...]; RIVPROF 13/1/21.

\section{NAI = National Archives of Nigeria, Ibadan}

CSO 26 Chief Secretary's Office, Lagos

CSO 26/2/11929; CSO 26/5/44869; CSO 26/5/46023; CSO 26/5/46119. 
MNA = National Archive of Mauritius, Coromandel, Mauritius

Z2A Police Reports and Correspondence

JB $4 ; \mathrm{Z2B} / 6$.

TAD $=$ Transvaal Archives Depot, Pretoria, South Africa (TAB)

SNA Secretary for Native Affairs

SNA 325,1657 .

TNA $=$ The National Archives of the UK, London, United Kingdom

CO Colonial Office

554 West Africa Original Correspondence

583 Nigeria Original Correspondence

657 Nigeria: Sessional Papers

847 Africa: Original Correspondence

852 Economic General Department and predecessors

927 Research Department: Colonial Social Science Research Council

1047 Maps and Plans: Series II

FCO Foreign and Commonwealth Office

65 West African Department: Registered Files (JW Series)

FO Foreign Office and Foreign and Commonwealth Office

93 Protocols of Treaties

366 Diplomatic Service Administration Office 
367 Records of the Slave Trade and African Departments

371 Political Departments: General Correspondence from 1906-1966

458 Consulate and Legation, Liberia

HS Special Operations Executive

3 Africa and Middle East Group

CO 554/105/3; [...]; CO 554/109/8; [...]; CO 554/114/10; [...]; CO 554/119/5; [...]; CO 554/124/17; CO 554/124/18; CO 554/124/19; [...]; CO 554/127/13; CO 554/127/14; CO 554/127/15; CO 554/127/16; [...]; CO 554/139/5; CO 554/139/6; [...]; CO 554/154/1; CO 554/154/2; [...]; CO 554/169/1; CO 554/169/2; [...]; CO 554/329; CO 554/330; CO 554/331; [...]; CO 554/657; [...]; CO 554/1344; CO 554/1345; CO 554/1346; CO 554/1347; [...]; CO 554/2002; [...]; CO 554/2502; [...]; CO 583/176/8; [...]; CO, 583/193/8; [...]; CO 583/229/5; CO 583/229/5; [...]; CO 583/242/22; [...]; CO 583/248; [...]; CO 583/263; CO 583/263/16; [...]; CO 657/52; CO 657/53; [...]; CO 847/26/1; CO 847/26/7; [...]; CO 852/375/18; [...]; CO 927/158/3; [...]; CO 1018/36; [...]; CO 1047/243; CO 1047/688; [...]; FCO 25/732; FCO 58/1692; [...]; FCO 58/2100; [...]; FCO 65/327; [...]; FCO 65/431; FCO 65/432; [...]; FCO 65/617; FCO 65/618; FCO 65/619; FCO 65/620; FCO 65/621; FCO 65/622; FCO 65/623; [...]; FCO 65/928; FCO 65/929; [...]; FCO 65/1097; [...]; FCO 65/1293; FCO 65/1294; [...]; FO 93/99/73; [...]; FO 366/3211; [...]; FO 367/254; [...]; FO 367/268; [...]; FO 367/353; [...]; FO 371/22669; [..]; FO 371/23171; [..]; FO 371/23394; [..]; FO $371 / 24510 ; \quad[\ldots] ;$ FO 371/24526; [...]; FO 371/26904; [...]; $\quad$ FO 371/26908; [...]; FO 371/26922; [...]; FO 371/31245; [...]; $\quad$ FO 371/31266B; FO 371/31267; [...]; FO 371/34771; FO 371/34772; [...]; FO 371/39661; [...]; FO 371/49598; [..]; FO 371/49640; [..]; FO 371/60141; [...]; FO 371/60392; [...]; FO 371/146562; FO 458/106; [...]; FO 458/112; [...]; FO 458/125; FO 458/126; FO 458/127; HS 3/77; HS $3 / 78$. 
SAD = Central Archives Depot, Pretoria, South Africa

NA Native Affairs

NA 2,5766/2(2).

SOAS = Archives \& Special Collections, SOAS Library, London, UK

CBMS Conference of British Missionary Societies

MMS Methodist Missionary Society

MMSL Methodist Missionary Society Library

MCF Movement of Colonial Freedom

Reading Room: Kingdom Overseas, Methodist Missionary Society

CBMS Box CBMS $\backslash A \backslash T \backslash 12.4 \backslash 308$; MMS West Africa Correspondence Fernando Po; French West Africa 1933/39 - 9; MMS West Africa Correspondence Fernando Po; French West Africa 1930/33 I; MMS/Special Series/Notes and Transcripts/FBN 1 (fiche 15-17);

MMS/Special Series/Biographical/West Africa/Box 1193A; MMSL $\mathrm{MSS} / 028 ; \mathrm{MCF} / \mathrm{COU} / 046$.

\section{RHL = Rhodes House Library, Oxford}

Private Papers of Former Colonial Officials

MSS. Brit. Emp. s.16-25 Papers of the Anti-Slavery Society

600.18 s. 21/XI (7); 600.18 s. 21/XI (10); 669 (175); 718 r. 6; 723.12 r. 145 (1955:2); 723.13 s.4 /1930; 723.14 r. 12; 723.14 s. 82 (1938-46); 723.17 s.1; C05.R00585; C96.S00338; CO 657/53; Confined to Social Sci...; FCO, 65/384, Intellige...; JQ3702.A98; Mss Afr. 51927 (1); Mss Afr. 5 1983; Mss. Afr. s. 697 (1); MSS. Brit. Emp. s.22 ; MSS. Brit. Emp. S.24. 


\section{Government Publications}

China, and Cuba Commission. 1993[1876]. The Cuba Commission Report: A Hidden History of the Chinese in Cuba: The Original English-Language Text of 1876. Baltimore: Johns Hopkins University Press.

Comisión para el Desarrollo Económico de Fernando Poo y Rio Muni. 1963. 'Plan de desarrollo económico de la Guinea Ecuatorial: 1964-1967'. Madrid: Presidencia del Gobierno.

Dirección de Agricultura de los territorios españoles del Golfo de Guinea. 1944. Anuario de estadística y catastro de la Dirección de Agricultura. Madrid: Dirección General de Marruecos y Colonias.

España, and Adolfo Enrique Millán López. 1967. Legislación de Guinea Ecuatorial: repertorio cronólogico de legislación. Años 1961-1967. Madrid: M.L. Carrasco.

España, Ministerio de Trabajo, and Delegación Provincial del Golfo de Guinea. 1958. Reglamentación Del Trabajo de 9 de Noviembre de 1953. Palma de Mallorca: Ministerio de Trabajo.

India. 1896. 'Report of the Labour Enquiry Commission'. Calcutta: Government Printer.

—. 1906. 'Proceedings of the Assam Labour Enquiry Committee in the Recruiting and Labour Districts, Vol. I (Evidence)'. Calcutta: Government Printer.

Gobierno General de los Territorios Españoles del Golfo de Guinea. 1955. 'Memoria de la labor realizada en el período 1949-1955'. Madrid: Rama.

Great Britain. 1920. 'Spanish Guinea'. Historical Section of the Foreign Office. No. 132. London: H.M. Stationery Office.

Guinea Ecuatorial. 1971. Conoce Guinea Ecuatorial. Malabo: n.p.

Llompart Aulet, Sebastian, and Negociado de Estadística del Gobierno General. 1945. 'Anuario Estadístico de Los Territorios Españoles Del Golfo de Guinea [1942- 
1945]'. Madrid: Dirección General de Marruecos y Colonias.

Negociado de Estadística del Gobierno General. 1946. 'Anuario estadistico de los territorios españoles del Golfo de Guinea'. Madrid: Dirección General de Marruecos y Colonias.

— 1960. 'Resúmenes estadísticos: Provincias de Fernando Poo y Río Muni, 1958-1959’. Madrid: Dirección General de Plazas y Provincias Africanas.

Nigeria. 1945. 'Annual Report of the Department of Labour, Nigeria, for the Year 1944'. Lagos: Government Printer.

- 1945. 'Annual Report on the Department of Labour, Nigeria, for the Year 1943'. Lagos: Government Printer.

- 1950. 'Annual Report on the Department of Labour and Resettlement of ExServicemen 1949/50'. Lagos: Government Printer.

Nigeria, and Aba Commission of Inquiry. 1930. 'Notes of Evidence Taken by the Commission of Inquiry Appointed to Inquire into the Disturbance in the Calabar and Owerri Provinces, December, 1929'. Lagos: Government Printer.

- 1930. 'Report of the Commission of Inquiry Appointed to Inquire into the Disturbances in the Calabar and Owerri Provinces, December, 1929'. Lagos: Government Printer.

Nigerian Parliament. 1958. 'Report of the Parliamentary Delegation to Fernando Poo \& Rio Muni 1957'. Lagos: Federation of Nigeria.

Partido Unico Nacional. 1971. 'Formacion Politica Anticolonialista'. Santa Isabel: Diario de la Guinea Ecuatorial.

Patronato de Indígenas de los Territorios Españoles del Golfo de Guinea. 1956. 'Datos para su historia y antecedentes y memoria del 1954'. Santa Isabel.

United States Department of Labor. 1966. Labor Digests on Countries in Africa. Washington: Bureau of Labor Statistics. 


\section{Labour Treaties and Agreements ${ }^{1}$}

Spain and King Williams of Bimbia, 'Convenio', 1 February 1862.

Spain and Liberia, 'Convenio entre S.M. Católica el Rey de España y el Excelentísimo

Sr. Presidente de la Republica de Liberia, para el reclutamiento de braceros en la República de Liberia, para trabajar en la colonia de Fernando Póo', 22 May 1914 [revoked September 1927].

Sindicato Agrícola de Guinea and Allen Yancy and Samuel Ross, 'Private Labor Agreement', 1928 [revoked in 1929].

Spain and French Cameroons, 'Tratado con Camarones para la recluta de trabajadores en la Colonia francesa', 8 January 1934 [revoked by French February 1936].

Spain and Nigeria. 'Colony and Protectorate of Nigeria and Spanish Territories of the Gulf of Guinea. Treaty Regarding the Recruitment in Nigeria of Native Labourers for Working in the Spanish Territories of the Gulf of Guinea', Lagos, Nigeria, 9 December 1942 [in effect May 1943].

- Modifications. December 1950. 'Los Excelentísimos Señores Gobernador y Comandante Jefe de la Colonia de Nigeria y Gobernador General de los Territorios Españoles del Golfo de Guinea, 'en su deseo de introducir en el Tratado que suscribieron en la cuidad de Lagos le nueve de diciembre de 1942, para la recluta y control de los trabajadores nigerianos, las modificaciones que una practica y experiencia de ocho años aconsejan, han procedido a la revision de los preceptos del mismo ajustándolos a las necesidades actuales y han acordado, en interes de ambos Gobiernos y de los patronos y trabajadores a quienes directamente atañe, la conclusion del siguiente nuevo Tratado, que sustituirá al anterio y entrara en vigor el dia primer de enero de 1951'.

- Revised Agreement. 1 October 1954.

- Further modifications. 1 September 1957.

${ }^{1}$ For a breakdown and details, copies in English and Spanish, and meetings and minutes and drafts, search a post I made that is on the internet: "Index: Treaty all years. Anglo-Spanish Labour Treaty/Spanish-Nigerian Labour Treaty/Nigeria-Equatorial Guinea Labour Treaty. 1942-1973”. 
- Spain and Nigeria. 'Convenio con Nigeria para contratación de trabajadores', or 'Agreement concluded between the Government of the Federation of Nigeria and the Government of the Spanish state for the recruitment of Nigerian adult male workers in the former country with the object of working in the Spanish Ecuatorial Provinces of Fernando Póo and Rio Muni'. Lagos, Nigeria, 1 May 1963.

- Equatorial Guinea and Nigeria. 'Agreement concluded between the Federal Military Government of the Federal Republic of Nigeria and the Government of the Republic of Equatorial Guinea for the recruitment in Nigeria of Nigerian adult male workers with the object of working in the Republic of Equatorial Guinea'. Lagos, Nigeria, 31 December 1971. 


\section{Labour Legislation}

For all labour laws and a complete compilation of all legislation up to 1945, and between 1961-1967, see:

Llompart Aulet, Sebastian. 1946. Legislación del trabajo de los territorios españoles del Golfo de Guinea. Madrid: Dirección General de Marruecos y Colonias.

Miranda Junco, Agustín. 1945. Leyes coloniales: legislación de los territorios españoles del Golfo de Guinea. Madrid: Imprenta Sucesores de Rivadeneyra.

España, Ministerio de Trabajo, and Delegación Provincial del Golfo de Guinea. 1958. Reglamentación Del Trabajo de 9 de Noviembre de 1953. Palma de Mallorca: Ministerio de Trabajo.

Millán López, Adolfo Enrique. 1967. Legislación de Guinea Ecuatorial: repertorio cronólogico de legislación. Años 1961-1967. Madrid: M.L. Carrasco.

\section{Cited Legislation}

‘Reglamento para el Servicio Doméstico', Real Orden, 14 January 1863.

'Proyecto de reglamento para el regimen de los trabajadores que lleguen a esta Isla, bien sean contratados en la Costa Vecina, bien procedentes de aprehensiones hechas a los buques negreros por nuestra marina de guerra', 9 December 1862, AGA, C-81/07124.

‘Contratación krumanes', Real Orden, 28 September 1867.

'Reglamento del trabajo indígena para los territorios españoles del Golfo De Guinea', 6 August 1906.

'Vagos y maleantes', Aviso, 30 November 1908.

'Presentación trabajadores', Orden. Curaduría Colonial, 25 June 1910.

'Reglamento Recluta', Decreto, 7 July 1912.

‘Alimentación y trato al bracero’, Decreto, 27 July 1913. 
'Identidad braceros', Aviso, 1 May 1926.

'La recluta será libre', Decreto, 14 December 1927.

Restringir la vagancia’, Decreto, 2 December 1933.

'Reglamentacion de contrata de braceros', Decreto, 2 February 1935.

'Vagos y maleantes', Ordenanza, 22 August 1936.

'Ordenacion del Contrato de Trabajo de la Región Ecuatorial', 24 Mayo 1962. 


\section{Newspapers \& Periodicals}

$A B C$. 1968. 'Ha facellido el General Don José Díaz de Villegas', August 11.

Africa: An International Business, Economic and Political Monthly. 1976. 'Nigerian Exodus', March.

Arnold-Foster, Mark. 1976. 'The Cocoa Slaves of Fernando Po'. The Guardian, November 12.

Bassey, Beatrice. 1961. 'Nigerians in Chains'. West African Pilot, January 31.

Boletin Oficial de los territorios españoles del Golfo de Guinea (Government Gazette or Official bulletin of the Spanish territories in the Gulf of Guinea), 1907-1959 (continues as Boletín Oficial de Guinea until 1968).

Bona Ekatem, J.E. 1939. 'El Trabajo en Fernando Poo (Extracto)'. La Guinea Española, September 3.

Bosshard, A. 1976. 'La Guinee Equatoriale recourt a l'esclavage pour ses plantations de cacao'. Journal de Geneve, August 31.

B.P. 1939. 'Brujerias de extranjeros'. La Guinea Española, September 17.

Bravo Carbonell, Juan. 1930. 'De la Guinea Española: El trabajo indígena'. El Sol, June 2.

Candidus. 1947. 'Recruitment of Labour to Fernando Po'. Nigerian Eastern Mail, April 5.

Cesar Banciella, Jose. 1942. 'Spanisch-Guinea'. Deutsche Kolonial Zeitung, May.

Daily Times. 1958. 'I was sold as a slave at the age of two'. June 11.

—. 1958. 'Nine Nigerian “Chiefs” Appointed in Fernando Poo'. August 22.

—. 1962. '500 Nigerians Desert Fernando Po', May 9. 
—. 1975. 'Students Want Action Against Santa Isabel: 2000 Back from Hell', January 18.

Dandeson Green. 1947. 'Recruitment of Labour To Fernando Po Is Done Under Treaty With Spanish Govt'. Eastern Nigeria Guardian, April 17.

Dodds, Rev. F.W. 1939. 'Nigerian Labourers in Fernando Po'. West Africa, June 24.

Drum. 1961. “"Smuggling - Nigeria”s Curse”, January.

Eastern Nigeria Guardian. 1945. 'Writer Vehemently Condemns Idea of Labour Recruiting to Fascist Territory', March 1.

- 1957. 'Fernando Poo', August 14.

Ebri, O. L. 1961. 'Slavery in Fernando Po'. West African Pilot, February 11.

El Defensor de Guinea. 1931. 'La Lamentable Leyenda', December 3.

—. 1933. 'Hospitalidad Excesiva', November 2.

España Colonial. 1929. 'Los braceros chinos', February 1.

González, Francisco G. 1936. 'Reportaje sobre la expedicion a la Guinea Española'. El Nacionalista, October 5.

Haden-Guest, Leslie. 1939. 'Letter to the Editor: Nigerians Workers in Fernando Po'. West Africa, July 22.

Hart, Gabriel. 1957. 'Public Opinion: Recruitment For Fernando Po Labour'. Nigerian Daily Standard, July 30.

Industria en Guinea. 1955. 'Hablando con el Delegado de Trabajo de la Guinea', September.

J. Abala Egbe. 1945. 'Mr. Sosoo'. Eastern Nigeria Guardian, February 22.

Jones Niger, Alfredo. 1931. 'Replica'. El Defensor de Guinea, November 29. 
Lardner, H.H. 1900. 'Songo Town Its Capabilities and Prospects'. Sierra Leone Weekly News, May 19.

L’Figaro. 1959. 'Espagne sous l'equator', November 13.

Methodist Missionary Society. 1947. 'West Africa'. The Church on Trial: The Report of 1946, the 161st Year of Methodists Missions.

Martins, Lola. 1962. 'Journey to Hell's Island: How It All Started'. Express, February 21.

—. 1962. 'African Tradition Abused in Fernando Poo”. Express, February 22.

—. 1962. 'Labourers Go Singing: Life with the Nigerians in Fernando Poo'. Express, February 22.

Mbadiwe. 1954. 'Nigerian Workers in Po Will Be Protected: Government Promises'. West African Pilot, August 26.

Morning Post. 1965. 'Call for action on Fernando Po island', January 27.

Morning Post. 1965. 'Portugal and South Africa: A Dangerous Alliance', September 28.

Moto Nsa, Severo. 1972. 'New Ville, Alias Campo Yaounde.' Diario de La Guinea Ecuatorial, December 5.

Nerín, Gustau. 2011. 'Carne de Plantación'. La Aventura de La Historia, January.

New York Times. 1930. 'Slavery Conditions in Liberia', October 27.

Nigerian Outlook. 1961. 'We Were Tortured, Starved', January 27.

Njoku, Linus B. 1961. 'The Fernando Po Question'. West African Pilot, February 3.

España Nueva: Diario de La Noche. 1913. 'Cosas Del Mundo’, April 4.

Observer. 1939. 'Matters of Moment'. The Nigerian Daily Times, July 15.

Otegbeye, Olatunji. 1961. 'To the Youths of Nigeria'. West African Pilot, November 11. 
Pan, Peter. 1962. 'The Brutal Island'. Sunday Times, February 18.

—. 1962. 'Wickid Laws and Wickid Rulers'. Sunday Times, February 25.

—. 1962. “"Spanish” is a Synonym for Savages'. Sunday Times, March 4.

—. 1962. 'Fernando Po. Govt. Investigates Alleged Brutalities.' Daily Times, March 21.

—. 1962. 'Fernando Po: The Minister Dodged the Issue'. Daily Times, March 23.

—. 1963. 'Nigerian Killed in "Brutal Island"'. Daily Times, July 19.

—. 1965. 'Life with Peter Pan: The Brutal Island'. Daily Times, January 27.

Pepple, Isaac. 1956. '17 Days in a Spanish Prison’. Drum, June.

—. 1957. 'Free Ticket to Hell'. Drum, April.

Perez, Dionisio. 1930. 'España acusada de esclavismo?' La Voz Galicia, January 26.

Salvador. 1936. 'Slavery in Spanish Guinea'. West Africa Review, May.

Schuyler, George. 1931. 'Wide "Slavery" Persisting in Liberia, Post Reveals. Is Liberia a Slave State?'. New York Evening Post, June 29.

Shepherd, Rev. Ewart. 1939. 'Nigerian Labourers in Fernando Po. Dr. Haden Guest Misinformed'. West Africa, May 13.

Shepherd, Rev. Ewart. 1939. 'Nigerian Labourers in Fernando Po', West Africa, 15 July.

Sierra Leone Daily Mail. 1936. 'Sensational Arrest at Fernando Po', September 16.

Smith, H.S. 1961. 'Spanish Guinea'. The Observer, April 30.

Sunday Express. 1961. 'Court Told of Faked Photographs', February 5.

Sunday Post. 1965. 'Murder In Fernando Po: Three Nigerians Shot Dead by Spanish Authority Police-Labour Leader Alleges', January 24. 
Sunday Times. 1960. '27 Point Resolution by Zikists', October 16.

_. 1962. 'Fernando Poo: The People's Voice', March 18.

The Lagos Weekly Record. 1903. 'The Labour Ordinance in Northern Nigeria', October 24.

—. 1911. 'The House Rule Ordinance', May 8.

The Nigerian Chronicle. 1976. 'Nigerians Pulled Out. Time For Reprisal', January 12.

The Nigerian Daily Times. 1939. 'Fernando Po Labour Conditions', July 13.

The Nigerian Eastern Mail. 1939. 'The Fernando Po Slave Traffic', February 25.

- 1939. 'Spanish Slavery', March 11.

_. 1939. 'The Fernando Po Planters And Nigerian Labour', July 8.

The West African Pilot. 1939. 'The Nigerian Easter Mail Alleges Slavery in Oron', January 21.

Tofu, Signor. 1976. 'Welcome Back to Freedom'. The Nigerian Chronicle, February 1.

Udoma, Inyang. 1976. '20,000 Nigerians Expected Home'. The Nigerian Chronicle, January 15.

—. 1976. 'Macias Nguema's Bloody Hell'. The Nigerian Chronicle, January 15.

—. 1976. 'Stop the Fascist'. The Nigerian Chronicle, January 18.

V.S. 1962. 'Hell on Earth'. New Times, May 23.

West Africa. 1958. 'Nigeria over the Water', January 1.

Zik. 1936. 'Inside Stuff: Fernando Po'. African Morning Post, May 27. 


\section{Interviews}

All interviews have been anonymized. Most took place over the course of several months in Equatorial Guinea in 2012 and 2013. I also conducted interviews with former settlers and imperial functionaries in Spain, between 2010 and 2013. 


\section{Bibliography}

Acemoglu, Daron, and Alexander Wolitzky. 2011. 'The Economics of Labor Coercion'. Econometrica 79 (2): 555-600.

Aderinto, Saheed, and Paul Osifodunrin. 2015. “"500 Children Missing in Lagos”: Child Kidnapping and Public Anxiety in Colonial Nigeria'. In Children and Childhood in Colonial Nigerian Histories, edited by Saheed Aderinto, 97-121. New York: Palgrave Macmillan.

Afigbo, Adiele E. 1982. 'The Native Revenue Ordinance in the Eastern Provinces: The Adventures of a Colonial Legislative Measure'. In Studies in Southern Nigerian History, edited by Boniface Obichere, 71-100. London: Frank Cass.

2006. The Abolition of the Slave Trade in Southeastern Nigeria, 1885-1950. Rochester: University Rochester Press.

Agiri, B. A. 1983. 'The Development of Wage Labour in Agriculture in Southern Yorubaland 1900-1940'. Journal of the Historical Society of Nigeria 12 (1/2): 95-107.

Ahuja, Ravi. 2009. 'Networks of Subordination-Networks of the Subordinated: The Ordered Spaces of South Asian Maritime Labour in an Age of Imperialism (c1890-1947)'. In The Limits of British Colonial Control in South Asia: Spaces of Disorder in the Indian Ocean Region, edited by Ashwini Tambe and Harald Fischer-Tine, 13-48. London: Routledge.

Akinyemi, Bolaji. 1970. 'Nigeria and Fernando Poo, 1958-1966: The Politics of Irridentism'. African Affairs 69 (276): 236-49.

Akoda, Winifred. 2007. 'Using the Archives for Research: A Historian's Experience'. Journal of the Historical Society of Nigeria 17: 75-84.

Alexander, Catherine. 2001. 'Legal and Binding: Time, Change and Long-Term Transactions'. Journal of the Royal Anthropological Institute 7 (3): 467-85. 
Allen, Richard B. 1999. Slaves, Freedmen and Indentured Laborers in Colonial Mauritius. Cambridge: Cambridge University Press.

2012. 'Re-Conceptualizing the "New System of Slavery". Man In India 92 (2): $225-45$.

- 2012. "European Slave Trading, Abolitionism, and "New Systems of Slavery" in the Indian Ocean', PORTAL: Journal of Multidisciplinary International Studies 9 https://epress.lib.uts.edu.au/journals/index.php/portal/article/view/2624, 2.

2014. 'Slaves, Convicts, Abolitionism and the Global Origins of the PostEmancipation Indentured Labor System'. Slavery \& Abolition 35 (2): 328-48.

Allina, Eric. 2003. 'Resistance and the Social History of Africa'. Journal of Social History 37 (1): 187-98.

- 2012. Slavery by Any Other Name: African Life Under Company Rule in Colonial Mozambique. Charlottesville: University of Virginia Press.

Alvarez Jusue, Aurelio. 1933. Ley de vagos y maleantes: Exposicion historica de la legislación española. Precedentes parlamentarios. La ley actual y su procedimineto. Madrid: Gongora.

Amin, Shahid, and Marcel van der Linden, eds. 1997. 'Peripheral'Labour?: Studies in the History of Partial Proletarianization. Cambridge: Cambridge University Press.

Anderson, David M. 2000. 'Master and Servant in Colonial Kenya, 1895-1939'. The Journal of African History 1 (3): 459-85.

Ardener, Edwin. 1960. Plantation and Village in the Cameroons: Some Economic and Social Studies. London: Oxford University Press.

Ardener, Edwin, and Shirley Ardener. 1996. Kingdom on Mount Cameroon: Studies in the History of the Cameroon Coast, 1500-1970. New York: Berghahn Books. 
Arizcun Carrera, Eugenio, and José María Martínez y de Pons. 1935. 'Memoria sobre los territorios españoles del Golfo de Guinea'. Madrid: Dirección General Marruecos y Colonias.

Arrighi, Giovanni. 1970. 'Labour Supplies in Historical Perspective: A Study of the Proletarianization of the African Peasantry in Rhodesia'. Journal of Development Studies 6 (3): 197-234.

Artucio, Alejandro. 1979. The Trial of Macias in Equatorial Guinea: The Story of a Dictatorship. Geneva: International Commission of Jurists, International University Exchange Fund.

Asiegbu, Johnson U. J. 1969. Slavery and the Politics of Liberation 1787-1861: A Study of Liberated African Emigration and British Anti-Slavery Policy. New York: Africana Pub. Corp.

Asiwaju, A. I. 1976. 'Migrations as Revolt: The Example of the Ivory Coast and the Upper Volta before 1945'. The Journal of African History 17 (4): 577-94.

Atiyah, Patrick S. 1979. The Rise and Fall of Freedom of Contract. Oxford: Oxford University Press.

Atkins, Keletso E. 1993. The Moon Is Dead! Give Us Our Money!: The Cultural Origins of an African Work Ethic, Natal, South Africa, 1843-1900. Portsmouth: Heinemann.

Austen, Ralph A. 1970. 'The Abolition of the Overseas Slave Trade a Distorted Theme in West African History'. Journal of the Historical Society of Nigeria 5 (2): $257-74$.

Austin, Gareth. 2005. Labour, Land, and Capital in Ghana: From Slavery to Free Labour in Asante, 1807-1956. Rochester: University of Rochester Press. . 2009. 'Cash Crops and Freedom: Export Agriculture and the Decline of Slavery in Colonial West Africa'. International Review of Social History 54 (1): $1-37$. 
- 2009. 'Factor Markets in Nieboer Conditions: Pre-Colonial West Africa, c.1500-c.1900'. Continuity and Change 24 (1): 23-53.

Aworawo, David. 1999. 'Foreign Policy and the Travails of Nigerian Migrants in Equatorial Guinea, 1930-1980'. Nigerian Journal of International Affairs 25 (2): $24-35$.

- 2010. 'Decisive Thaw: The Changing Pattern of Relations between Nigeria and Equatorial Guinea, 1980-2005'. Journal of International and Global Studies 1 (2): 89-109.

Azevedo, Celia Maria Marinho de. 1987. Onda negra, medo branco: o negro no imaginário das elites, século XIX. Rio de Janeiro: Paz e Terra.

Azikiwe, Ben N. 1932. 'In Defense of Liberia'. The Journal of Negro History 17 (1): $30-50$.

Baak, Paul E. 1999. 'About Enslaved Ex-Slaves, Uncaptured Contract Coolies and Unfreed Freedmen: Some Notes about "Free" and "Unfree" Labour in the Context of Plantation Development in Southwest India, Early Sixteenth Century-Mid 1990s'. Modern Asian Studies 33 (1): 121-57.

Balachandran, Gopalan. 1997. 'Recruitment and Control of Indian Seamen: Calcutta, 1880-1935'. International Journal of Maritime History 9 (1): 1-18.

- 2011. 'Making Coolies, (Un)making Workers: "Globalizing" Labour in the Late-19th and Early-20th Centuries'. Journal of Historical Sociology 24 (3): 266-96.

Balandier, Georges. 1970. The Sociology of Black Africa: Social Dynamics in Central Africa. London: Praeger Publishers.

Balboa Navarro, Imilcy, and José A Piqueras Arenas. 2000. Los brazos necesarios: inmigración, colonización y trabajo libre en Cuba, 1878-1898. Valencia: Fundación Instituto de Historia Social. 
Balboa Navarro, Imilcy. 2011. 'Libertos, vagos y bandoleros: La reglamentación del trabajo tras la abolición de la esclavitud (Cuba 1886-1895)'. Relaciones 32 (127): 87-116.

Ballano Gonzalo, Fernando. 2014. Aquel negrito del África tropical: el colonialismo español en Guinea (1778-1968). Madrid: Sial/Casa de África.

Balogun, J. O. 1944. The Existence of Virtual Monopoly in the British Colony of Nigeria. Lagos: self-published.

Banaji, Jairus. 2003. 'The Fictions of Free Labour: Contract, Coercion, and So-Called Unfree Labour'. Historical Materialism 11 (3): 69-95.

. 2006. 'Modernizing the Historiography of Rural Labour: An Unwritten Agenda'. In Companion to Historiography, edited by Michael Bentley, 88-104. London: Routledge.

Barchiesi, Franco. 2012. 'How far from Africa's Shore? A Response to Marcel van der Linden's Map for Global Labor History'. International Labor and WorkingClass History 82: 77-84.

Barchiesi, Franco, and Stefano Bellucci. 2014. 'Introduction'. International Labor and Working-Class History 86 (3): 4-14.

Barnard, Cecil, and Thomas Victor Bulpin. 1967. The Ivory Trail. Cape Town: Books of Africa.

Barrientos, Stephanie, Uma Kothari, and Nicola Phillips. 2013. 'Dynamics of Unfree Labour in the Contemporary Global Economy'. The Journal of Development Studies 49 (8): 1037-41.

Basden, George T. 1921. Among the Ibos of Nigeria. Seeley, Service \& Co.: London. https://archive.org/details/amongibosofniger00basd.

Bastian, Misty L. 1993. 'Bloodhounds Who Have No Friends: Witchcraft and Locality in the Nigerian Popular Press'. In Modernity and Its Malcontents: Ritual and Power in Postcolonial Africa, edited by Jean Comaroff and John Comaroff, 129-66. Chicago: University of Chicago Press. 
— 1998. 'Fires, Tricksters and Poisoned Medicines: Popular Cultures of Rumor in Onitsha, Nigeria and Its Markets', Etnofoor 11 (2): 111-32.

Bates, Crispin. 2000. 'Coerced and Migrant Labourers in India: The Colonial Experience'. Edinburgh Papers In South Asian Studies 13: 2-33.

Bauer, Arnold J. 1975. Chilean Rural Society from the Spanish Conquest to 1930. Cambridge: Cambridge University Press.

- 1979. 'Rural Workers in Spanish America: Problems of Peonage and Oppression'. The Hispanic American Historical Review 59 (1): 34-63.

Baumann, Oscar. 1888. Eine afrikanische Tropeninsel: Fernando Póo und die Bube. Wien: Hölzel. https://archive.org/details/fernandopounddie00baum.

Becroft, Captain, and J. B. King. 1844. 'Details of Explorations of the Old Calabar River, in 1841 and 1842'. Journal of the Royal Geographical Society of London 14: $260-83$.

Behal, Rana. 2006. 'Power Structure, Discipline, and Labour in Assam Tea Plantations under Colonial Rule'. International Review of Social History 51 (S14): 143-72.

Behal, Rana, and Prabhu Mohapatra. 1992. "“Tea and Money versus Human Life”: The Rise and Fall of the Indenture System in the Assam Tea Plantations 18401908'. Journal of Peasant Studies 19 (3-4): 142-72.

Behal, Rana Partap, and Marcel van der Linden, eds. 2006. Coolies, Capital, and Colonialism: Studies in Indian Labour History. Cambridge: Cambridge University Press.

Behrens, Christine. 1974. Les Kroumen de la côte occidentale d'Afrique. Talence: Ministère de l'éducation nationale.

Beinart, William. 1979. 'Joyini Inkomo: Cattle Advances and the Origins of Migrancy from Pondoland'. Journal of Southern African Studies 5 (2): 199-219.

Beltrán y Rózpide, Ricardo. 1901. La Guinea Española. Barcelona: Soler. 
Benjamin, Walter. 1986. 'Critique of Violence'. In Reflections: Essays, Aphorisms, Autobiographical Writings, 277-300. New York: Schocken Books.

1989. 'Zur Kritik der Gewalt'. In Gesammelte Schriften 2, edited by Rolf Tiedemann and Hermann Schweppenhäuser, 179-204. Frankfurt am Main: Suhrkamp.

Berman, Bruce J. 1990. Control and Crisis in Colonial Kenya: The Dialectic of Domination. Athens: Ohio University Press.

Berman, Bruce J., and John M. Lonsdale. 1980. 'Crises of Accumulation, Coercion and the Colonial State: The Development of the Labor Control System in Kenya, 1919-1929'. Canadian Journal of African Studies 14 (1): 55-81.

Berman, Sanford. 1956. 'Spanish Guinea: Enclave Empire'. Phylon 17 (4): 349-64.

- 1957. 'Pepple's Story: Footnote to Spanish Guinea'. The Phylon Quarterly 18 (3): 306-8.

Bernault, Florence, and Janet Roitman, eds. 2003. A History of Prison and Confinement in Africa. Portsmouth: Heinemann.

Berry, Sara. 1995. 'Stable Prices, Unstable Values: Same Thoughts on Monetization and the Meaning of Transactions in West African Economies'. In Money Matters: Instability, Values, and Social Payments in the Modern History of West African Communities, edited by Jane Guyer, 299-313. Portsmouth: Heinemann.

Best, Lloyd A. 1968. 'Outlines of a Model of Pure Plantation Economy'. Social and Economic Studies 17 (3): 283-326.

Bhattacharya, Neeladri. 2004. Labouring Histories: Agrarian Labour and Colonialism. Noida: V.V. Giri National Labour Institute.

Bhattacharya, Sabyasachi. 2006. 'Labour Forms and International Labour Flows in the Context of North-South Relationship: An Overview'. In The Long Twentieth Century: Globalization Under Hegemony, The Changing World Economy, edited by Kwame S. Jomo, 1-32. New Delhi: Oxford University Press. 
Blanchard, Peter. 1979. 'Recruitment of Workers in the Peruvian Sierra at the Turn of the Century: Enganche System'. Inter-American Economic Affairs 33 (3): 6383.

Bolland, O. Nigel. 1981. 'Systems of Domination after Slavery: The Control of Land and Labor in the British West Indies after 1838'. Comparative Studies in Society and History 23 (4): 591-619.

— 1986. 'Labour Control and Resistance in Belize in the Century After 1838'. Slavery \& Abolition 7 (2): 175-87.

Bolt, Jutta, and Erik Green. 2015. 'Was the Wage Burden Too Heavy? - Settler Farming, Profitability, and Wage Shares of Settler Agriculture in Nyasaland, C. 1900-60'. The Journal of African History 56 (2): 217-38.

Bolt, Maxim. 2012 'Waged Entrepreneurs, Policed Informality: Work, the Regulation of Space and the Economy of the Zimbabwean-South African Border'. Africa 82 (1): 111-130.

2014. 'The Sociality of the Wage: Money Rhythms, Wealth Circulation and the Problem with Cash on the Zimbabwean-South African Border'. Journal of the Royal Anthropological Institute 20 (1): 113-30.

Bonelli Rubio, Juan Maria. 1949. 'Geografía económica de la Guinea española'. In España en África, edited by José Diaz de Villegas y Bustamente, 193-204. Madrid: Instituto de Estudios Africanos.

Bonhomme, Julien. 2012. 'The Dangers of Anonymity: Witchcraft, Rumor, and Modernity in Africa'. HAU: Journal of Ethnographic Theory 2 (2): 205-33.

Brass, Tom. 1990. 'Class Struggle and the Deproletarianisation of Agricultural Labour in Haryana (India)'. The Journal of Peasant Studies 18 (1): 36-67.

1994. 'Some Observations on Unfree Labour, Capitalist Restructuring, and Deproletarianization'. International Review of Social History 39 (2): 255-75. 1999. Towards a Comparative Political Economy of Unfree Labour: Case Studies and Debates. London: Routledge. 
—. 2003. 'Why Unfree Labour Is Not "so-Called": The Fictions of Jairus Banaji'. Journal of Peasant Studies 31 (1): 101-36.

- 2011. Labour Regime Change in the Twenty-First Century: Unfreedom, Capitalism and Primitive Accumulation. Leiden: Brill.

—. 2014. 'Debating Capitalist Dynamics and Unfree Labour: A Missing Link?' The Journal of Development Studies 50 (4): 570-82.

Brass, Tom, and Henry Bernstein. 1992. 'Introduction: Proletarianisation and Deproletarianisation on the Colonial Plantation'. In Plantations, Proletarians, and Peasants in Colonial Asia, edited by E. Valentine Daniel, Henry Bernstein, and Tom Brass, 1-42. London: Cass.

Bravo Carbonell, Juan. 1917. Fernando Póo y el Muni: sus misterios y riquezas: su colonización. Madrid: Alrededor del Mundo.

—. 1925. En la selva virgen del muni. Madrid: Z. Ascasibar.

Breckenridge, Keith. 2000. 'Confounding the Documentary State: Cape Workers' Letters on the Early Witwatersrand.' In History and African Studies Seminar. University of KwaZulu-Natal, Durban, South Africa.

- 2008. 'Power Without Knowledge: Three Nineteenth Century Colonialisms in South Africa'. Journal of Natal and Zulu History 26 (1): 3-30.

- 2012. 'No Will to Know: The Rise and Fall of African Civil Registration in Twentieth-Century South Africa'. Proceedings of the British Academy 182: $357-83$.

- 2014. Biometric State: The Global Politics of Identification and Surveillance in South Africa. Cambridge: Cambridge University Press.

- 2014. 'Flesh Made Words: Fingerprinting and the Fantasy of Documentary Panopticism, 1900-1930'. Occasional Paper, no. 23: 76-96. http://ojs.ruc.dk/index.php/ocpa/article/view/3789. 
Breckenridge, Keith, and Simon Szreter, eds. 2012. Registration and Recognition: Documenting the Person in World History. Oxford: Oxford University Press.

Breman, Jan. 1989. Taming the Coolie Beast: Plantation Society and the Colonial Order in Southeast Asia. Oxford: Oxford University Press.

Breman, Jan, Isabelle Guérin, and Aseem Prakash. 2009. India's Unfree Workforce: Of Bondage Old and New. New Delhi: Oxford University Press.

Brook, Ian. 1966. The One-Eyed Man is King. London: Cassell.

Brooks, George E. 1972. The Kru Mariner in the Nineteenth Century: An Historical Compendium. Newark: Liberian Studies Association in America.

2003. Eurafricans in Western Africa: Commerce, Social Status, Gender, and Religious Observance from the Sixteenth to the Eighteenth Century. Athens: Ohio University Press.

Brown, Carolyn A. 1988. 'The Dialectics of Colonial Labour Control: Class Struggles in the Nigerian Coal Industry, 1914-1949'. Journal of Asian and African Studies 23: 32-59.

- 2003. 'We Were All Slaves': African Miners, Culture, and Resistance at the Enugu Government Colliery. Portsmouth: Heinemann.

Brown, Carolyn A., and Marcel van der Linden. 2010. 'Shifting Boundaries Between Free and Unfree Labor: Introduction'. International Labor and Working-Class History 78 (1): 4-11.

Brown, Laurence. 2007. "“A Most Irregular Traffic": The Oceanic Passages of the Melanesian Labor Trade'. In Many Middle Passages: Forced Migration and the Making of the Modern World, edited by Emma Christopher, Marcus Rediker, and Cassandra Pybus, 184-203. Berkeley: University of California Press.

Brown, Robert T. 1973. 'Fernando Po and the Anti-Sierra Leonean Campaign: 18261834'. The International Journal of African Historical Studies 6 (2): 249-64. 
Brunet, José Manuel, José Luis Cosculluela, and José María Mur. 2008. Guinea en Patués: De los bueyes del Valle de Benasque al cacao de la isla de Fernando Poo. Huesca: Diputación de Huesca.

Burton, Antoinette. 2007. 'Not Even Remotely Global? Method and Scale in World History'. History Workshop Journal 64 (1): 323-28.

Burton, Richard Francis. 1862. Wanderings in West Africa from Liverpool to Fernando Po. London: Bradbury and Evans. http://www.archive.org/details/wanderingsinwest02burtiala.

1864. A Mission to Gelele, King of Dahome. London: Tylston and Edwards. https://archive.org/details/missiontogelelek01burtuoft.

Cabanellas, Guillermo. 1933. ¡Esclavos!: (notas sobre el África negra). Valencia: Ediciones Cuadernos de Cultura.

. 1944. La selva siempre triunfa: novela del África española. Buenos Aires: Editorial Ayacucho.

Caldeira, Arlindo Manuel. 2011. 'Learning the Ropes in the Tropics: Slavery and the Plantation System on the Island of São Tomé'. African Economic History 39: $35-71$.

Callebert, Ralph. 2012. 'Cleaning the Wharves: Pilferage, Bribery, and Social Connections on the Durban Docks in the 1950s'. Canadian Journal of African Studies 46 (1): 23-38.

Campbell, Persia Crawford. 1929. Chinese Coolie Emigration to Countries Within the British Empire. London: P.S. King \& Son.

Campos Serrano, Alicia. 2002. De colonia a Estado: Guinea Ecuatorial, 1955-1968. Madrid: Centro de Estudios Políticos y Constitucionales.

—. 2005. 'Colonia, derecho y territorio en el Golfo de Guinea: Tensiones del colonialismo español en el siglo XX'. Quaderni Fiorentini 33: 1-26. 
Campos Serrano, Alicia, and Plácido Micó Abogo. 2006. Labour and Trade Union Freedom in Equatorial Guinea. Madrid: Fundación Paz y Solidaridad Serafín Aliaga.

Carles, Emilio. 1932. Misioneros, negreros y esclavos: Notas de un viaje a Fernando Poo. Valencia: Cuadernos de Cultura.

Carswell, Grace, and Geert De Neve. 2013. 'From Field to Factory: Tracing Transformations in Bonded Labour in the Tiruppur Region, Tamil Nadu'. Economy and Society 42 (3): 430-54.

Carter, Marina. 1992. 'Strategies of Labour Mobilisation in Colonial India: The Recruitment of Indentured Workers for Mauritius'. Journal of Peasant Studies 19 (3/4): 229-45.

—. 1993. 'The Transition from Slave to Indentured Labour in Mauritius'. In The Wages of Slavery: From Chattel Slavery to Wage Labour in Africa, the Carribbean, and England, edited by Michael Twaddle, 115-36. London: Frank Cass.

- 1995. Servants, Sirdars, and Settlers: Indians in Mauritius, 1834-1874. Oxford: Oxford University Press.

Castro Antolín, Mariano L. de, and Maria Luisa de la Calle Muñoz. 1992. Origen de la colonización española en Guinea Ecuatorial (1777-1860). Valladolid: Universidad de Valladolid.

Cervantes-Rodriguez, Margarita. 2011. International Migration in Cuba: Accumulation, Imperial Designs, and Transnational Social Fields. University Park: Pennsylvania State University Press.

Chakrabarty, Dipesh. 1992. 'Postcoloniality and the Artifice of History: Who Speaks for “Indian” Pasts?' Representations 37: 1-26.

Christopher, Emma, Marcus Rediker, and Cassandra Pybus, eds. 2007. Many Middle Passages: Forced Migration and the Making of the Modern World. Berkeley: University of California Press. 
Christophersen, Paul. 1975. 'A Note on the Words Dash and Ju-Ju in West African English'. In Perspectives on Black English, edited by Joey Lee Dillard, 212-15. Berlin: Walter de Gruyter.

Chuku, Gloria. 2005. Igbo Women and Economic Transformation in Southeastern Nigeria, 1900-1960. London: Routledge.

Clarence-Smith, William G. 1979. Slaves, Peasants, and Capitalists in Southern Angola, 1840-1926. Cambridge: Cambridge University Press.

1985. 'The Impact of the Spanish Civil War and the Second World War on Portuguese and Spanish Africa'. The Journal of African History 26 (4): 309-26.

- 1986. 'Spanish Equatorial Guinea, 1898-1940'. In The Cambridge History of Africa: From 1905 to 1940, edited by Arthur D. Roberts, 537-44. Cambridge: Cambridge University Press.

. 1990. 'Emigration from Western Africa, 1807-1940'. Itinerario 14 (1): 45-60. - 1990. 'The Hidden Costs of Labour on the Cocoa Plantations of São Tomé and Príncipe, 1875-1914'. Portuguese Studies 6: 152-72.

- 1993. 'Cocoa Plantations and Coerced Labor in the Gulf of Guinea, 18701914'. In Breaking the Chains: Breaking the Chains: Slavery, Bondage and Emancipation in Africa and Asia, edited by Martin A. Klein, 150-70. Madison: University of Wisconsin Press.

—. 1993. 'Labour Conditions in the Plantations of Sao Tomé and Principe, 18751914'. Slavery \& Abolition 14 (1): 149-67.

- 1994. 'African and European Cocoa Producers on Fernando Poo, 1880s to 1910s'. The Journal of African History 35 (2): 179-99.

Clarke, Duncan G. 1974. Contract Workers and Underdevelopment in Rhodesia. Gwelo: Mambo Press.

Clastres, Pierre. 1987. Society Against the State: Essays in Political Anthropology. New York: Zone Books. 
Clavero, Bartolome. 2006. 'Bioko, 1837-1876: constitucionalismo de europa en áfrica, derecho internacional consuetudinario del trabajo mediante'. Quaderni Fiorentini per la Storia del Pensiero Giuridico Moderno 35: 429-546.

Coe, Cati. 2012. 'How Debt Became Care: Child Pawning and Its Transformations in Akuapem, the Gold Coast, 1874-1929'. Africa 82 (2): 287-311.

Collins, W.H. 1934. 'Fernando Poo To-Day by Rev. W.H. Collins'. Kingdom Overseas (Magazine of the Wesleyan Methodist Missionary Society) 2: 92-94.

Cooper, Frederick. 1977. Plantation Slavery on the East Coast of Africa. New Haven: Yale University Press.

. 1980. From Slaves to Squatters: Plantation Labor and Agriculture in Zanzibar and Coastal Kenya, 1890-1925. New Haven: Yale University Press.

-1987. On the African Waterfront: Urban Disorder and the Transformation of Work in Colonial Mombasa. New Haven: Yale University Press.

- 1995. 'Work, Class and Empire: An African Historian's Retrospective on E. P. Thompson'. Social History 20 (2): 235-41.

- 1996. Decolonization and African Society: The Labor Question in French and British Africa. Cambridge: Cambridge University Press.

2000. 'Back to Work: Categories, Boundaries and Connections in the Study of Labour'. In Racializing Class, Classifying Race: Labour and Difference in Britain, the USA, and Africa, edited by Peter Alexander and Rick Halpern, 21332. New York: St. Martin's Press.

- 2003. 'Industrial Man Goes to Africa'. In Men and Masculinities in Modern Africa, edited by Lisa A. Lindsay and Stephan Miescher, 128-37. Portsmouth: Heinemann.

2005. Colonialism in Question: Theory, Knowledge, History. Berkeley: University of California Press. 
- 2006. 'African Labor History'. In Global Labour History: A State of the Art, edited by Jan Lucassen, 45-66. Bern: Peter Lang.

Cooper, Frederick, Florencia E. Mallon, Allen F. Isaacman, William Roseberry, and Steve J. Stern. 1993. Confronting Historical Paradigms: Peasants, Labor, and the Capitalist World System in Africa and Latin America. Madison: University of Wisconsin Press.

Coquery-Vidrovitch, Catherine. 1975. 'Research on an African Mode of Production'. Critique of Anthropology 2 (4/5): 38-71.

- 1985. 'The Colonial Economy of the Former French, Belgian and Portuguese Zones'. In General History of Africa, Volume VII, Africa Under Colonial Domination 1880-1935, edited by Unesco International Scientific Committee for the Drafting of a General History of Africa and A. Adu Boahen, 351-82. Paris: UNESCO.

Cordell, Dennis D, Joel W Gregory, and Victor Piché. 1996. Hoe and Wage: A Social History of a Circular Migration System in West Africa. Boulder: Westview Press.

Cordero Torres, José María. 1941. Tratado elemental de derecho colonial español. Instituto de estudios políticos. Colección España ante el mundo. Madrid: Editora Nacional.

—. 1953. Política colonial. Madrid: Ed. Cultura Hispánica.

Craton, Michael. 1984. 'The Historical Roots of the Plantation Model'. Slavery \& Abolition 5 (3): 189-221.

Crisp, Jeff. 1984. 'The Labour Question in the Gold Coast, 1870-1906'. In Proletarianisation in the Third World: Studies in the Creation of a Labour Force Under Dependent Capitalism, edited by Barry Munslow and Martin H. J. Finch, 18-42. London: Croom Helm.

Cronjé, Suzanne. 1976. Equatorial Guinea, the Forgotten Dictatorship: Forced Labour and Political Murder in Central Africa. London: Anti-Slavery Society. 
Crush, Jonathan. 1986. 'Swazi Migrant Workers and the Witwatersrand Gold Mines 1886-1920'. Journal of Historical Geography 12 (1): 27-40. 1987. Struggle for Swazi Labour, 1890-1920. McGill: Queen’s Press.

Curtin, Philip D. 1989. Death by Migration: Europe's Encounter with the Tropical World in the Nineteenth Century. Cambridge: Cambridge University Press.

- 1995. Why People Move: Migration in African History. Waco: Markham Press Fund.

. 1998. The Rise and Fall of the Plantation Complex. Cambridge: Cambridge University Press.

Davidson, Basil. 1984. 'Appendix Equatorial Guinea, c.1940 to 1975'. In The Cambridge History of Africa: From C. 1940 to C. 1975, edited by Michael Crowder, 806-11. Cambridge University Press.

Davidson, Lance S. 1985. 'Shanghaied! The Systematic Kidnapping of Sailors in Early San Francisco'. California History 10: 10-17.

Daviron, Benoit. 2010. 'Mobilizing Labour in African Agriculture: The Role of the International Colonial Institute in the Elaboration of a Standard of Colonial Administration, 1895-1930.' Journal of Global History 5 (3): 479-501.

Davis, David Brion. 1975. The Problem of Slavery in the Age of Revolution, 17701823. Ithaca: Cornell University Press.

Davis, Ronald Wayne. 1976. Ethnohistorical Studies on the Kru Coast. Newark: Liberian Studies.

De Castro, Steve. 2001. 'Modern Slave Plantations to Firms and Labor Markets: Incentive Theory for a Growth Disaster'. In Programa de Seminários Acadêmicos. Universidade de Brasília. http://citeseerx.ist.psu.edu/viewdoc/download?doi=10.1.1.199.1921\&rep=rep1 \&type $=$ pdf. 
de Silva, S. B. D. 2012. The Political Economy of Underdevelopment. London: Routledge.

Delegación Peninsular para Café de las Camaras Oficiales Agricolas de Guinea. 1972. 'Memoria del año 1971'. Madrid.

Deleuze, Gilles, and Félix Guattari. 1984. Anti-Oedipus: Capitalism and Schizophrenia. London: Continuum.

-1987. A Thousand Plateaus: Capitalism and Schizophrenia. Minneapolis: University of Minnesota Press.

De Neve, Geert. 1999. 'Asking for and Giving Baki: Neo-Bondage, or the Interplay of Bondage and Resistance in the Tamilnadu Power-Loom Industry'. Contributions to Indian Sociology 33 (1-2): 379-406.

Derrida, Jacques. 1992. Given Time. I, Counterfeit Money. Chicago: University of Chicago Press.

de Ste. Croix, Geoffrey E. M. 1981. The Class Struggle in the Ancient Greek World: From the Archaic Age to the Arab Conquests. Ithaca: Cornell University Press.

- 1988. 'Slavery and Other Forms of Unfree Labour'. In Slavery: And Other Forms of Unfree Labour, edited by Leonie Archer, 19-33. London: Routledge.

Dike, Kenneth O. 1956. Trade and Politics in the Niger Delta: 1830-1885. Oxford: Clarendon Press.

Dirlik, Arif, Vinay Bahl, and Peter Gran. 2000. History After the Three Worlds: PostEurocentric Historiographies. London: Rowman \& Littlefield.

Domar, Evsey D. 1970. 'The Causes of Slavery or Serfdom: A Hypothesis'. The Journal of Economic History 30 (1): 18-32.

Domingues da Silva, Daniel, David Eltis, Philip Misevich, and Olatunji Ojo. 2014. 'The Diaspora of Africans Liberated from Slave Ships in the Nineteenth Century'. The Journal of African History 55 (3): 347-69. 
Dore, Elizabeth. 2003. 'Patriarchy from Above, Patriarchy from Below, Debt Peonage on Nicaraguan Coffee Estates, 1870-1930'. In The Global Coffee Economy in Africa, Asia and Latin America, 1500-1989, edited by William Gervase Clarence-Smith and Steven Topik, 209-35. Cambridge: Cambridge University Press.

- 2006. Myths of Modernity: Peonage and Patriarchy in Nicaragua. Durham: Duke University Press.

Dougnon, Isaie. 2009. 'Migration for “White Man’s Work": An Empirical Rebuttal to Marxist Theory'. African Identities 7 (3): 353-71.

Drescher, Seymour. 1999. From Slavery to Freedom: Comparative Studies in the Rise and Fall of Atlantic Slavery. New York: New York University Press.

Dunn, Richard S. 1984. 'Servants and Slaves: The Recruitment and Employment of Labor'. In Colonial British America: Essays in the New History of the Early Modern Era, edited by Jack P. Greene and J. R. Pole, 157-94. Baltimore: Johns Hopkins University Press.

Eckert, Andreas. 1998. 'Slavery in Colonial Cameroon, 1880s to 1930s'. Slavery \& Abolition 19 (2): 133-48.

1999. 'Slavery in Colonial Cameroon, 1880s to 1930s'. In Slavery and Colonial Rule in Africa, edited by Suzanne Miers and Martin A. Klein, 133-49. London: Routledge.

Ejituwu, Nkparom C. 1995. 'Anglo-Spanish Employment Agency: Its Role in the Mobilization of Nigerian Labour for the Island of Fernando Po'. In The Nigeria-Equatorial Guinea Transborder Cooperation: Proceeding of the Nigeria-Equatorial Guinea Transborder Cooperation Workshop, Held at Metropolitan Hotel, Calabar, 21-28 November, 1992, edited by Bawuro M. Barkindo, A. I. Asiwaju, and Ricardo Elo Mabale, 42-57. Lagos: Terminal Products.

- 1998. 'Old Calabar Revisited'. In The Multi-Disciplinary Approach to African

History: Essays in Honour of Ebiegberi Joe Alagoa, edited by Ebiegberi Joe 
Alagoa and Nkparom C. Ejituwu. Port Harcourt: University of Port Harcourt Press.

Ekechi, Felix K. 1989. Tradition and Transformation in Eastern Nigeria: A Sociopolitical History of Owerri and Its Hinterland, 1902-1947. Kent: Kent State University Press.

- 2003. 'Pawnship in Igbo Society'. In Pawnship, Slavery, and Colonialism in Africa, edited by Paul E. Lovejoy and Toyin Falola, 165-87. Trenton: Africa World Press.

- 2010. Pioneer, Patriot, and Nigerian Nationalist: A Biography of the Reverend M.D. Opara, 1915-1965. Durham: Carolina Academic Press.

Eltis, David. 1993. 'Europeans and the Rise and Fall of African Slavery in the Americas: An Interpretation'. The American Historical Review 98 (5): 13991423.

Emenanjo, E. Nolue. 1980. 'Slangs and Colloquialisms in Modern Igbo: A Preliminary Socio-Linguistic Study'. Ikenga: Journal of African Studies 4 (2): 49-65.

Emmer, Pieter, and E. van den Boogaart. 1986. 'Colonialism and Migration: An Overview'. In Colonialism and Migration: Indentured Labour Before and After Slavery, edited by Pieter Emmer and E. van den Boogaart, 3-28. New York: Springer.

Emmer, Pieter C. 1990. 'European Expansion and Migration: The European Colonial Past and Intercontinental Migration. An Overview'. Itinerario 14 (1): 11-24.

Enahoro, Peter. 1971. How to Be a Nigerian. Ibadan: Daily Times of Nigeria.

Epale, Simon Joseph. 1985. Plantations and Development in Western Cameroon, 18851975: A Study in Agrarian Capitalism. New York: Vantage Press.

Evans, Chris. 2012. "“Carabalí" and "Culíes" at El Cobre: African Slaves and Chinese Indentured Labourers in the Service of Swansea Copper'. In World of Copper: Globalizing the Industrial Revolution c.1830-1870. Burra, Australia. 
Fage, John D. 1969. 'Slavery and the Slave Trade in the Context of West African History'. The Journal of African History 10 (3): 393-404.

Falola, Toyin. 1999. 'The End of Slavery among the Yoruba'. In Slavery and Colonial Rule in Africa, edited by Suzanne Miers and Martin A. Klein, 232-50. London: Frank Cass.

Falola, Toyin, and Tyler Fleming. 2005. 'Africa’s Media Empire: Drum's Expansion to Nigeria'. History in Africa 32 (1): 133-64.

Falola, Toyin, and Paul E. Lovejoy, eds. 1994. Pawnship in Africa: Debt Bondage in Historical Perspective. Boulder: Westview Press.

- eds. 2003. Pawnship, Slavery, and Colonialism in Africa. Trenton: Africa World Press.

Fegley, Randall. 2010. 'Death's Waiting Room: Equatorial Guinea's Long History of Slavery'. In African Systems of Slavery, edited by Jay Spaulding and Stephanie Beswick, 135-59. Trenton: Africa World Press.

Ferguson, James. 1990. 'Mobile Workers, Modernist Narratives: A Critique of the Historiography of Transition on the Zambian Copperbelt'. Journal of Southern African Studies 16 (3): 385-412.

Fernández, Cristóbal. 1962. Misiones y misioneros en la Guinea española; historia documentada de sus primeros azarosos días, 1883-1912. Madrid: Editorial Co. Cul.

Fernández Fígares, Maria Dolores. 2003. La colonización del imaginario: imágenes de África. Granada: Universidad de Granada.

Fernandez, James W. 1982. Bwiti: An Ethnography of the Religious Imagination in Africa. Princeton: Princeton University Press.

Finley, Moses. 1973. The Ancient Economy. Berkeley: University of California Press. 1980. Ancient Slavery and Modern Ideology. New York: Viking Press. 
Fischer, Michael H. 2006. 'Working Across the Seas: Indian Maritime Labourers in India, Britain, and in Between, 1600-1852'. In Coolies, Capital, and Colonialism: Studies in Indian Labour History, edited by Rana Behal and Marcel van der Linden, 21-46. Cambridge: Cambridge University Press.

Floyd, Barry. 1969. Eastern Nigeria: A Geographical Review. London: Macmillan.

Forde, Cyril D., and G. I. Jones. 1967. The Ibo and Ibibio-Speaking Peoples of SouthEastern Nigeria. London: Stone and Cox.

Foreman, John. 1906. The Philippine Islands: A Political, Geographical, Ethnographical, Social and Commercial History of the Philippine Archipelago, Embracing the Whole Period of Spanish Rule, with an Account of the Succeeding American Insular Government. New York: C. Scribner's Sons. http://archive.org/details/island00forephilippinerich.

Freund, Bill. 1982. 'Theft and Social Protest among the Tin Miners of Northern Nigeria'. Radical History Review 1982 (26): 68-86.

—. 1984. 'Labor and Labor History in Africa: A Review of the Literature'. African Studies Review 27 (2): 1-58.

Frost, Diane. 1999. Work and Community among West African Migrant Workers since the Nineteenth Century. Liverpool: Liverpool University Press.

Frykman, Niklas. 2015. 'Impressment, Kidnapping, and Panyarring'. In The Princeton Companion to Atlantic History, edited by Joseph C. Miller, 240-42. Princeton: Princeton University Press.

Gabriel, Pere. 2006. 'Más allá de los exilios politicos: Proscritos y deportados en el siglo XIX'. In Las figuras del desorden: heterodoxos, proscritos y marginados : actas del V Congreso de Historia Social de España, Ciudad Real, 10 y 11 de noviembre de 2005, edited by Santiago Castillo and Pedro Oliver, 197-223. Madrid: Siglo XXI de España Editores.

Galarza, Ernesto. 1964. Merchants of Labor: The Mexican Bracero Story. Santa Barbara: McNally and Loftin. 
Garcia Gimeno, Fernando. 2004. Fernando el africano. Barcelona: Arco Press.

Ghosh, Kaushik. 1999. 'A Market for Aboriginality: Primitivism and Race Classification in the Indentured Labour Market of Colonial India'. In Subaltern Studies X: Writings on South Asian History and Society, edited by Gautam Bhadra, Gyan Prakash, and Susie Tharu, 10:8-48. New Delhi: Oxford University Press.

Gibson, Charles. 1964. The Aztecs under Spanish Rule: A History of the Indians of the Valley of Mexico, 1519-1810. Stanford: Stanford University Press.

Glasman, Joel. 2014. 'Unruly Agents: Police Reform, Bureaucratization, and Policemen's Agency in Interwar Togo'. Journal of African History 55 (1): 79100.

Goerg, Odile. 2003. 'De la ségrégation colonial à la tentation sécessionniste: «l'urbanisme sécuritaire »'. In Security, Crime and Segregation in West African Cities since the 19th Century, edited by Laurent Fourchard and Isaac Olawale Albert, 245-63. Paris: Karthala.

Gonzales, Michael J. 1980. 'Capitalist Agriculture and Labour Contracting in Northern Peru, 1880-1905'. Journal of Latin American Studies 12 (2): 291-315.

Goody, Jack. 2007. The Theft of History. Cambridge: Cambridge University Press.

Graeber, David. 1996. 'Beads and Money: Notes toward a Theory of Wealth and Power'. American Ethnologist 23 (1): 4-24.

1996. 'Love Magic and Political Morality in Central Madagascar, 1875-1990'. Gender \& History 8 (3): 416-39.

- 2005. 'Fetishism as Social Creativity, or Fetishes Are Gods in the Process of Construction'. Anthropological Theory 5 (4): 407-38.

—. 2006. 'Turning Modes of Production Inside Out: Or, Why Capitalism Is a Transformation of Slavery'. Critique of Anthropology 26 (1): 61-85. https://libcom.org/files/graeber_2006a.pdf. 
- 2007. 'David Graeber Provisional Autonomous Zone, or The Ghost-State in Madagascar'. In Possibilities: Essays on Hierarchy, Rebellion and Desire. Oakland: AK Press.

—. 2011. Debt: The First 5,000 Years. New York: Melville House.

- 2012. 'On Social Currencies and Human Economies: Some Notes on the Violence of Equivalence'. Social Anthropology 20 (4): 411-28.

- 2012. 'The Sword, the Sponge, and the Paradox of Performativity: Some Observations on Fate, Luck, Financial Chicanery, and the Limits of Human Knowledge'. Social Analysis 56 (1): 25-42.

Graham, Edgar, Ingrid Floering, and D. K Fieldhouse. 1984. The Modern Plantation in the Third World. New York: St. Martin's Press.

Gray, Christopher, and François Ngolet. 1999. 'Lambaréné, Okoumé and the Transformation of Labor Along the Middle Ogooué (gabon), 1870-1945'. The Journal of African History 40 (1): 87-107.

Green, Erik. 2014. 'The Economics of Slavery in the Eighteenth-Century Cape Colony: Revising the Nieboer-Domar Hypothesis'. International Review of Social History 59 (1): 39-70.

Greenfield, Sidney M. 1977. 'Madeira and the Beginnings of New World Sugar Cane Cultivation and Plantation Slavery: A Study in Institution Building'. Annals of the New York Academy of Sciences 292 (1): 536-52.

-. 1979. 'Plantations, Sugar Cane and Slavery'. Historical Reflections / Réflexions Historiques 6 (1): 85-119.

Gudeman, Stephen, and Alberto Rivera. 1990. Conversations in Colombia: The Domestic Economy in Life and Text. Cambridge: Cambridge University Press.

Guérin, Isabelle. 2013. 'Bonded Labour, Agrarian Changes and Capitalism: Emerging Patterns in South India'. Journal of Agrarian Change 13 (3): 405-23. 
Gutiérrez Sobral. 1901. 'Guinea Española: la crisis de braceros'. Revista de Geografía Colonial y Mercantil 2:12-15.

Guyer, Jane. 1999. 'Comparisons and Equivalencies in Africa and Melanesia'. In Money and Modernity: State and Local Currencies in Melanesia, edited by David Akin and Joel Robbins, 232-46. Pittsburgh: University of Pittsburgh Press.

- 2004. Marginal Gains: Monetary Transactions in Atlantic Africa. Chicago: University of Chicago Press.

- 2013. “"The Quickening of the Unknown”: Epistemologies of Surprise in Anthropology (the Munro Lecture, 2013)'. HAU: Journal of Ethnographic Theory $3283-307$. http://www.haujournal.org/index.php/hau/article/view/377.

- 2014. 'Gains and Losses in the Margins of Time: From West and Equatorial History to Present-Day South Africa, and Back'. Africa 84 (1): 146-50.

Haag, Pamela. 1999. Consent: Sexual Rights and the Transformation of American Liberalism. Ithaca: Cornell University Press.

Hahamovitch, Cindy. 2011. No Man's Land: Jamaican Guestworkers in America and the Global History of Deportable Labor. Princeton: Princeton University Press.

Hale, Robert L. 1935. "Force and the State: A Comparison of "Political" and “Economic” Compulsion'. Columbia Law Review 35 (2): 149-201.

Hammond, Richard James. 1966. Portugal and Africa, 1815-1910: A Study in Uneconomic Imperialism. Stanford: Stanford University Press.

Harman, Graham. 2011. The Quadruple Object. Washington: Zero Books.

Harneit-Sievers, Axel. 1996. 'African Business, "Economic Nationalism,” and British Colonial Policy: Southern Nigeria, 1935-1954'. African Economic History 24: $25-68$. 
- 2001. 'Dreams of Free Trade in Colonial Nigeria: Peter Eket Inyang Udoh and his Ibibio Ventures, 1929-1941'. In Africain Networks, Exchange and Spatial Dynamics, edited by Brigitte Reinwald, 187. Münster: LIT Verlag.

Harries, Patrick. 1993. Work, Culture, and Identity: Migrant Laborers in Mozambique and South Africa, C.1860-1910. Portsmouth: Heinemann.

Harris, Edward M. 2002. 'Did Solon Abolish Debt-Bondage?' The Classical Quarterly $52(2): 415-30$.

Herbert, Ulrich. 1997. Hitler's Foreign Workers: Enforced Foreign Labor in Germany Under the Third Reich. Cambridge: Cambridge University Press.

Herzog, Don. 1989. Happy Slaves: A Critique of Consent Theory. Chicago: University of Chicago Press.

Higgs, Catherine. 2012. Chocolate Islands: Cocoa, Slavery, and Colonial Africa. Athens: Ohio University Press.

- 2014. 'Happiness and Work: Portuguese Peasants, British Laborers, African Contract Workers, and the Case of São Tomé and Príncipe, 1901-1909'. International Labor and Working-Class History 86: 55-71.

Higman, Barry W. 1972. 'The Chinese in Trinidad, 1806-1838'. Caribbean Studies 12 (3): $21-44$.

Hill, Polly. 1997. The Migrant Cocoa-Farmers of Southern Ghana: A Study in Rural Capitalism. Münster: LIT Verlag.

Hofmeester, Karin, Jan Lucassen, and Filipa Ribeiro da Silva. 2014. 'No Global Labor History without Africa: Reciprocal Comparison and Beyond'. History in Africa 41: 249-76.

Hollup, Oddvar. 2000. 'Kinship and Marriage in the Construction of Identity and Group Boundaries among Indians in Mauritius'. In Culture, Creation, and Procreation: Concepts of Kinship in South Asian Practice, edited by Monika Böck and Aparna Rao, 219-43. Berghahn Books. 
Holsoe, Svend E. 1977. 'Slavery and Economic Response among the Vai (Liberia and Sierra Leone)'. In Slavery in Africa: Historical and Anthropological Perspectives, edited by Suzanne Miers and Igor Kopytoff, 287-303. Madison: University of Wisconsin Press.

Holt, Thomas C. 1992. The Problem of Freedom: Race, Labor, and Politics in Jamaica and Britain, 1832-1938. Baltimore: Johns Hopkins University Press.

Hopkins, Anthony G. 1968. 'Economic Imperialism in West Africa: Lagos, 18801921'. The Economic History Review 21 (3): 580-606. 1973. An Economic History of West Africa. London: Longman.

Horne, Gerald. 2007. The White Pacific: U.S. Imperialism and Black Slavery in the South Seas After the Civil War. Honolulu: University of Hawaii Press.

Howard, Philip A. 2015. Black Labor, White Sugar: Caribbean Braceros and Their Struggle for Power in the Cuban Sugar Industry. Baton Rouge: Louisiana State University Press.

Hu-DeHart, Evelyn. 1993. 'Chinese Coolie Labour in Cuba in the Nineteenth Century: Free Labour or Neo-Slavery?' Slavery \& Abolition 14 (1): 67-86.

_ 2007. 'La Trata Amarilla: The "Yellow Trade" and the Middle Passage, 18471884'. In Many Middle Passages: Forced Migration and the Making of the Modern World, edited by Emma Christopher, Marcus Rediker, and Cassandra Pybus, 166-83. Berkeley: University of California Press.

Imbua, David L. 2011. Intercourse and Crosscurrents in the Atlantic World: CalabarBritish Experience, 17th-20th Centuries. Durham: Carolina Academic Press.

Imoagene, Oshomha. 1990. Peoples of the Cross River Valley and the Eastern Delta. Ibadan: New-Era.

Inikori, Joseph E. 1982. 'Introduction'. In Forced Migration: The Impact of the Export Slave Trade on African Societies, edited by Joseph E. Inikori, 13-60. New York: Africana Pub. Co. 
- 2002. Africans and the Industrial Revolution in England: A Study in International Trade and Economic Development. New York: Cambridge University Press.

Irick, Robert L. 1982. Ch'ing Policy toward the Coolie Trade, 1847-1878. Taipei: Chinese Materials Center.

Jakobeit, Cord. 1987. ‘Äquatorialguinea: Schwierige Rehabilitation'. Africa Spectrum $22(2): 144-56$.

- 1995. 'Prospects for the Cocoa Economy in Equatorial Guinea: A High Quality Market Niche?' In Cocoa Cycles: The Economics of Cocoa Supply, edited by François Ruf and P.S. Siswoputranto, 219-30. Abington: Woodhead Publishing.

James, Deborah. 2012. 'Money-Go-Round: Personal Economies of Wealth, Aspiration and Indebtedness'. Africa 82 (1): 20-40.

James, Deborah, and Dinah Rajak. 2014. 'Credit Apartheid, Migrants, Mines and Money'. African Studies 73 (3): 455-76.

Jeeves, Alan. 1983. 'Over-Reach: The South African Gold Mines and the Struggle for the Labour of Zambesia, 1890-1920'. Canadian Journal of African Studies 17 (3): $393-412$.

- 1985. Migrant Labour in South Africa's Mining Economy: The Struggle for the Gold Mines' Labour Supply, 1890-1920. Kingston: Queen's University Press.

- 1990. 'Migrant Labour in the Industrial Transformation of South Africa, 19201960'. In Studies in the Economic History of Southern Africa: Volume Two: South Africa, Lesotho and Swaziland, edited by Z. A. Konczacki, Jane L. Parpart, and Timothy M. Shaw, 105-44. London: Routledge.

Jeeves, Alan, and Jonathan Crush, eds. 1997. White Farms, Black Labor: The State and Agrarian Change in Southern Africa, 1910-50. Portsmouth: Heinemann.

Jeffreys, M. D. W. 1949. 'Review of Water Transport. Origins and Early Evolution'. African Studies 8 (2): 104-6. 
Jodhka, Surinder S. 1995. 'Agrarian Changes, Unfreedom and Attached Labour'. Economic and Political Weekly 30 (31/32): 2011-13.

Johnson, David. 1992. 'Settler Farmers and Coerced African Labour in Southern Rhodesia, 1936-46'. The Journal of African History 33 (1): 111-28.

Johnson, John Flude, and British and Foreign Anti-slavery Society. 1843. Proceedings of the General Anti-Slavery Convention, Called by the Committee of the British and Foreign Anti-Slavery Society, and Held in London, from Tuesday, June 13th, to Tuesday, June 20th, 1843. London: J. Snow.

Jones, G. I. 1956. 'Report on the Position, Status and Influence of Chiefs and Natural Rulers in the Eastern Provinces of Nigeria'. Enugu: Government Printer. Government Publications.

- 1963. The Trading States of the Oil Rivers: A Study of Political Development in Eastern Nigeria. London: James Currey.

Kahn, Victoria. 2009. Wayward Contracts: The Crisis of Political Obligation in England, 1640-1674. Princeton: Princeton University Press.

Kaye, Anthony E. 2014. 'The Second Slavery: Modernity in the 19th-Century South and the Atlantic World'. In The Second Slavery: Mass Slaveries and Modernity in the Americas and in the Atlantic Basin, edited by Javier Lavina and Michael Zeuske, 175-97. Münster: LIT Verlag.

Keese, Alexander. 2014. "Forced Labour in the "Gorgulho Years": Understanding Reform and Repression in Rural São Tomé e Príncipe, 1945-1953'. Itinerario 38 (1): 103-24.

Kelly, John D. 1992. "Coolie” as a Labour Commodity: Race, Sex, and European Dignity in Colonial Fiji'. The Journal of Peasant Studies 19 (3-4): 246-67.

Kessler, Friedrich. 1943. 'Contracts of Adhesion-Some Thoughts About Freedom of Contract'. Columbia Law Review 43: 629-42. 
Killingray, David. 1989. 'Labour Exploitation for Military Campaigns in British Colonial Africa 1870-1945'. Journal of Contemporary History 24 (3): 483501.

Klein, Martin A. 1994. 'Slavery, the International Labour Market and the Emancipation of Slaves in the Nineteenth Century'. Slavery \& Abolition 15 (2): 197-220.

- 2002. Historical Dictionary of Slavery and Abolition. Lanham: Scarecrow Press.

Klein, Martin A., and Richard Roberts. 1987. 'The Resurgence of Pawning in French West Africa during the Depression of the 1930s'. African Economic History 16: $23-37$.

Klinteberg, Robert F. 1978. Equatorial Guinea Macias Country: The Forgotten Refugees. Geneva: International University Exchange Fund.

Kloosterboer, Willemina. 1960. Involuntary Labour since the Abolition of Slavery: A Survey of Compulsory Labour throughout the World. Leiden: Brill.

Knight, Alan. 1986. 'Mexican Peonage: What Was It and Why Was It?' Journal of Latin American Studies 18 (1): 41-74.

- 1988. 'Debt Bondage in Latin America'. In Slavery: And Other Forms of Unfree Labour, edited by Leonie Archer, 102-17. London: Routledge.

Kolapo, Femi J. 2002. 'Nineteenth Century Niger River Trade and the 1844-1862 Aboh Interregnum'. African Economic History 30: 1-29.

Konings, Piet. 1993. Labour Resistance in Cameroon: Managerial Strategies \& Labour Resistance in the Agro-Industrial Plantations of the Cameroon Development Corporation. London: James Currey Publishers.

Korieh, Chima. 2010. The Land Has Changed: History, Society and Gender in Colonial Eastern Nigeria. Calgary: University of Calgary Press.

Krissman, Fred. 2005. 'Sin Coyote ni Patrón: Why the "Migrant Network" Fails to Explain International Migration'. International Migration Review 39 (1): 4-44. 
Kubicek, Robert. 1990. 'Mining: Patterns of Dependence and Development 18701930'. In Studies in the Economic History of Southern Africa: Volume Two: South Africa, Lesotho and Swaziland, edited by Z. A. Konczacki, Jane L. Parpart, and Timothy M. Shaw, 64-87. London: Routledge.

Kynoch, Gary. 2003. 'Controlling the Coolies: Chinese Mineworkers and the Struggle for Labor in South Africa, 1904-1910'. The International Journal of African Historical Studies 36 (2): 309-29.

Laclau, Ernesto. 1971. 'Feudalism and Capitalism in Latin America'. New Left Review 67 (May-June): 19-38.

Lal, Brij V. 1983. 'Indian Indenture Historiography: A Note on Problems, Sources and Methods'. Pacific Studies 6 (2): 33-50.

Lamounier, Maria Lúcia. 2000. 'The "Labour Question” in Nineteenth Century Brazil: Railways, Export Agriculture and Labour Scarcity'. Department of Economic History, London School of Economics, Working Paper No. 59/00.

Lander, Richard, and John Lander. 1832. Journal of an Expedition to Explore the Course and Termination of the Niger: With a Narrative of a Voyage down That River to Its Termination. London: J. \& J. Harper.

Latham, A. J. H. 1971. 'Currency, Credit and Capitalism on the Cross River in the PreColonial Era'. The Journal of African History 12 (4): 599-605. 1973. Old Calabar, 1600-1891: The Impact of the International Economy Upon a Traditional Society. Oxford: Oxford University Press.

Latour, Bruno. 1993. The Pasteurization of France. Cambridge: Harvard University Press.

Law, Robin. 1994. 'On Pawning and Enslavement for Debt in the Pre-Colonial Slave Coast'. In Pawnship in Africa: Debt Bondage in Historical Perspective, edited by Toyin Falola and Paul E. Lovejoy, 55-69. Boulder: Westview Press. 
1995. 'Introduction'. In From Slave Trade to 'Legitimate' Commerce: The Commercial Transition in Nineteenth-Century West Africa, edited by Robin Law, 1-31. Cambridge: Cambridge University Press.

1999. 'Finance and Credit in Pre-Colonial Dahomey'. In Credit, Currencies, and Culture: African Financial Institutions in Historical Perspective, edited by Endre Stiansen and Jane Guyer, 15-38. Uppsala: Nordic Africa Institute.

- 2004. Ouidah: The Social History of a West African Slaving 'Port', 17271892. Athens: Ohio University Press.

Lecuona, Oscar Z. 2008. 'La United Fruit Company en Cuba: Organización del trabajo y resistencia obrera'. Clío América 2 (4): 238-58.

Levy, Norman. 1982. The Foundations of the South African Cheap Labour System. London: Routledge.

Linebaugh, Peter, and Marcus Rediker. 2000. The Many-Headed Hydra: Sailors, Slaves, Commoners, and the Hidden History of the Revolutionary Atlantic. New York: Verso.

Liniger-Goumaz, Max. 1979. La Guinée équatoriale: un pays méconnu. Paris: L'Harmattan.

—. 1987. 'La cuestion bracera: 150 años de busqueda de mano de obra en Guinea Equatorial'. Estudios de Asia y Africa 22 (74): 497-534.

_. 1988. Brève histoire de la Guinée Equatoriale. Paris: L’Harmattan.

-1988. Small Is Not Always Beautiful: The Story of Equatorial. London: Hurst.

Llompart Aulet, Sebastian. 1946. Legislación del trabajo de los territorios españoles del Golfo de Guinea. Madrid: Dirección General de Marruecos y Colonias.

—. 1961. 'Nigerianos en las provincias ecuatoriales'. Estadística española: revista del Instituto Nacional de Estadística 10: 63-70. 
Locke, John. 1728. Two Treatises of Government: In the Former the False Principles \& Foundation of Sir Robert Filmer \& His Followers, Are Detected \& Overthrown; the Latter Is an Essay Concerning the True Original, Extent \& End of Civil Government. London: A. Bettesworth.

Look Lai, Walton. 2002. 'Asian Contract and Free Migrations to the Americas'. In Coerced and Free Migration: Global Perspectives, edited by David Eltis, 22957. Stanford: Stanford University Press.

Lovejoy, Paul E. 2000. Transformations in Slavery: A History of Slavery in Africa. Cambridge: Cambridge University Press.

. 2014. 'Pawnship, Debt, and "Freedom" in Atlantic Africa During the Era of the Slave Trade: A Reassessment'. The Journal of African History 55 (1): 5578.

Lovejoy, Paul E., and Jan Hogendorn, eds. 1993. Slow Death for Slavery: The Course of Abolition in Northern Nigeria, 1897-1936. Cambridge: Cambridge University Press.

Lucassen, Jan. 1993. 'Free and Unfree Labour Before the Twentieth Century: A Brief Overview'. In Free and Unfree Labour, edited by Marcel van der Linden and Tom Brass, 45-56. Amsterdam: International Institute for Social History.

2006. 'The Brickmakers' Strikes on the Ganges Canal in 1848-1849'. In Coolies, Capital, and Colonialism: Studies in Indian Labour History, edited by Rana Behal and Marcel van der Linden, 21-46. Cambridge: Cambridge University Press.

Lucassen, Jan, and Leo Lucassen. 1997. Migration, Migration History, History: Old Paradigms and New Perspectives. Bern: Peter Lang.

2011. 'From Mobility Transition to Comparative Global Migration History'. Journal of Global History 6 (2): 299-307.

Lucena Salmoral, Manuel. 1996. Los códigos negros de la América española. Madrid: UNESCO. 
—. 1999. 'El derecho de coartación del esclavo en la América española'. Revista de indias 59 (216): 357-74.

Lynch, Hollis R. 2012. K. O. Mbadiwe: A Nigerian Political Biography, 1915-1990. New York: Palgrave Macmillan.

Lynn, Martin. 1984. 'Commerce, Christianity and the Origins of the "Creoles" of Fernando Po'. The Journal of African History 25 (3): 257-78.

- 1995. 'Factionalism, Imperialism and the Making and Breaking of Bonny Kingship C. 1830-1885'. Revue française d'histoire d'outre-mer 82 (307): 16992.

- 2002. Commerce and Economic Change in West Africa: The Palm Oil Trade in the Nineteenth Century. Cambridge: Cambridge University Press.

MacDonald, Andrew. 2012. 'The Identity Thieves of the Indian Ocean: Forgery, Fraud and the Origins of South African Immigration Control, 1890s-1920s'. In Registration and Recognition: Documenting the Person in World History, edited by Keith Breckenridge and Simon Szreter, 253-76. Oxford: Oxford University Press.

- 2014. 'Forging the Frontiers: Travellers and Documents on the South AfricaMozambique Border, 1890s-1940s'. Kronos 40 (1): 154-77.

MacGaffey, Janet, ed., 1991. The Real Economy of Zaire: The Contribution of Smuggling \& Other Unofficial Activities to National Wealth. Philadelphia: University of Pennsylvania Press.

Macías Martín, Francisco J. 2002. Cuba: Crisis política, crisis económica y emigración (1920-1935). Tegueste: Ediciones de Baile del Sol.

Madrid, Francisco. 1933. La Guinea incógnita: vergüenza y escándalo colonial. Madrid: Editorial España.

Manchuelle, François. 1997. Willing Migrants: Soninke Labor Diasporas, 1848-1960. Athens: Ohio University Press. 
Mandala, Elias C. 1990. Work and Control in a Peasant Economy: A History of the Lower Tchiri Valley in Malawi, 1859-1960. Madison: University of Wisconsin Press.

Manning, Patrick. 1986. 'Slave Trade, "Legitimate" Trade, and Imperialism Revisited: The Control of Wealth in the Bights of Benin and Biafra'. In Africans in Bondage Studies in Slavery and the Slave Trade, edited by Philip D. Curtin and Paul E. Lovejoy, 203-33. Madison: University of Wisconsin Press.

-1990. Slavery and African Life: Occidental, Oriental, and African Slave Trades. Cambridge: Cambridge University Press.

Mark-Thiesen, Cassandra. 2012. "The "Bargain" of Collaboration: African Intermediaries, Indirect Recruitment, and Indigenous Institutions in the Ghanaian Gold Mining Industry, 1900-1906'. International Review of Social History 57 (S20): 17-38.

Marshall, Woodville K., and Patrick Bryan. 2003. 'The Post-Slavery Labour Problem Revisited'. In Slavery, Freedom and Gender: The Dynamics of Caribbean Society, edited by Brian L. Moore, B. W. Higman, and Carl Campbell, 115-33. Kingston: University of the West Indies Press.

Martin, Anne. 1956. The Oil Palm Economy of the Ibibio Farmer. Ibadan: Ibadan University Press.

Martínez Carreras, Jose. 1985. 'Guinea Ecuatorial española en el contexto de la Segunda Guerra Mundial'. Cuadernos de historia moderna y contemporánea 6: $233-55$.

Martínez, Luis de Sequera. 2006. Poto Poto: las tropas de guarniación en los territorios españoles de Guinea. Madrid: Ministerio de Defensa.

Martin, Jane. 1985. 'Krumen "Down the Coast": Liberian Migrants on the West African Coast in the 19th and Early 20th Centuries'. The International Journal of African Historical Studies 18 (3): 401-23. 
Martino, Enrique. 2012. 'Clandestine Recruitment Networks in the Bight of Biafra: Fernando Pó's Answer to the Labour Question, 1926-1945'. International Review of Social History 57 (S20): 39-72.

2014. 'Open Sourcing the Colonial Archive - A Digital Montage of the History of Fernando Pó and the Bight of Biafra'. History in Africa 41: 387-415.

Martin, Susan M. 1988. Palm Oil and Protest: An Economic History of the Ngwa Region, South-Eastern Nigeria, 1800-1980. Cambridge: Cambridge University Press.

Marx, Karl. 1971. The Grundrisse. New York: Harper \& Row. 1974. Capital. London: Lawrence and Wishart.

Mauss, Marcel. 2002. The Gift: Forms and Function of Exchange in Archaic Society. London: Routledge.

Mbembe, Achille. 2001. On the Postcolony. Berkeley: University of California Press.

Mbilinyi, Marjorie. 1989. 'Women's Resistance in "Customary” Marriage: Tanzania's Runaway Wives'. In Forced Labour and Migration: Patterns of Movement Within Africa, edited by Abebe Zegeye and Shubi Ishemo, 211-54. London: Hans Zell.

McCreery, David. 1983. 'Debt Servitude in Rural Guatemala, 1876-1936'. The Hispanic American Historical Review 63 (4): 735-59.

Mckeown, Adam. 2004. 'Global Migration, 1846-1940'. Journal of World History 15 (2): $155-89$.

- 2012. 'How the Box Became Black: Brokers and the Creation of the Free Migrant'. Pacific Affairs 85 (1): 21-45.

-2013. Melancholy Order: Asian Migration and the Globalization of Borders. New York: Columbia University Press. 
Meagher, Arnold J. 2008. The Coolie Trade: The Traffic in Chinese Laborers to Latin America 1847-1874. Xlibris: Arnold J Meagher.

Meer, Y. S. 1980. Documents of Indentured Labour: Natal 1851-1917. Durban: Institute of Black Research.

Mhone, Guy C. Z. 1982. The Political Economy of a Dual Labor Market in Africa: The Copper Industry and Dependency in Zambia, 1929-1969. Fairleigh: Dickinson University Press.

Middleton, John. 2003. 'Merchants: An Essay in Historical Ethnography'. Journal of the Royal Anthropological Institute 9 (3): 509-26.

Miers, Suzanne. 1998. 'Slavery and the Slave Trade as International Issues 18901939'. Slavery and Abolition 19 (3): 16-37.

— 2000. 'Slavery to Freedom in Sub-Saharan Africa: Expectations and Reality'. In After Slavery: Emancipation and its Discontents, edited by Howard Temperley, 237-64. London: Frank Cass.

Miers, Suzanne, and Martin A. Klein, eds. 1999. Slavery and Colonial Rule in Africa. London: Routledge.

Miers, Suzanne, and Richard Roberts. 1988. 'The End of Slavery in Africa'. In The End of Slavery in Africa, edited by Suzanne Miers and Richard Roberts, 3-70. Madison: University of Wisconsin Press.

Miles, Robert. 1987. Capitalism and Unfree Labour: Anomaly or Necessity? London: Tavistock.

Miller, Ivor. 2009. Voice of the Leopard: African Secret Societies and Cuba. Jackson: University of Mississippi Press.

Miller, Joseph C. 1988. Way of Death: Merchant Capitalism and the Angolan Slave Trade, 1740-1830. Madison: University of Wisconsin Press.

—. 1997. 'O Atlântico escravista: açúcar, escravos e engenhos'. Afro-Ásia 19/20: 9-36. 
- 2012. The Problem of Slavery as History: A Global Approach. New Haven: Yale University Press.

Miranda Junco, Agustín. 1945. Leyes coloniales: legislación de los territorios españoles del Golfo de Guinea. Madrid: Imprenta Sucesores de Rivadeneyra.

Mohapatra, Prabhu. 2007. 'Eurocentrism, Forced Labour, and Global Migration: A Critical Assessment'. International Review of Social History 52 (1): 110-15.

- 2009. 'From Contract to Status? Or How Law Shaped Labour Relations in Colonial India 1780-1920'. In India's Unfree Workforce: Of Bondage Old and New, edited by Jan Breman, 96-125. New Delhi: Oxford University Press.

Hans Christian Monrad. 2009. Two Views from Christiansborg Castle: A Description of the Guinea Coast and its Inhabitants. Legon: Sub-Saharan Pub.

Moreno Fraginals, Manuel, Frank Moya Pons, and Stanley L. Engerman, eds. 1985. Between Slavery and Free Labor: The Spanish-Speaking Caribbean in the Nineteenth Century. Baltimore: Johns Hopkins University Press.

Moroney, Sean. 1978. 'Mine Worker Protest on the Witwatersrand, 1901-1912'. In Essays in Southern African Labour History, edited by Eddie Webster, 32-46. Johannesburg: Ravan Press.

Moulier-Boutang, Yann. 1998. De l'esclavage au salariat: économie historique du salariat bridé. Paris: Presses universitaires de France.

- 2006. De la esclavitud al trabajo asalariado: economía histórica del trabajo asalariado embridado. Barcelona: Ediciones AKAL.

Murray, Albert V. 1967. The School in the Bush: A Critical Study of the Theory and Practice of Native Education in Africa. New York: Routledge.

Murray, Martin J. 1992. "White Gold” or "White Blood”?: The Rubber Plantations of Colonial Indochina, 1910-40'. The Journal of Peasant Studies 19 (3-4): 41-67. 
—. 1995. "Blackbirding" at "Crooks" Corner': Illicit Labour Recruiting in the Northeastern Transvaal, 1910-1940'. Journal of Southern African Studies 21 (3): 373-97.

Mveng, Maurice. 1969. 'Note sur emigration des Camerounais ä Fernando Po entre les deux guerres mondiales'. Abbia 23: 34-43.

Naanen, Benedict B. B. 1991. “"Itinerant Gold Mines”: Prostitution in the Cross River Basin of Nigeria, 1930-1950'. African Studies Review 34 (2): 57-79.

Nair, Janaki. 1997. 'Dangerous Labour: Crime, Work and Punishment in Kolar Gold Fields, 1890-1946'. Studies in History 13 (1): 19-61.

Nair, Kannan K. 1972. Politics and Society in South Eastern Nigeria, 1841-1906: A Study of Power, Diplomacy and Commerce in Old Calabar. London: Routledge.

Najera Angulo, Luis. 1932. Los territorios españoles en el Golfo de Guinea: estado sanitario actual y su influencia sobre el desarrollo de la colonización. Madrid: Impr. del P. de H. de Intendencia e Intervención Militares.

Nascimento, Augusto. 2002. Desterro e contrato: moçambicanos a caminho de S. Tomé e Principe (anos 1940 a 1960). Vol. 19. Maputo: Arquivo Histórico de Moçambique.

— 2004. 'Escravatura, trabalho forçado e contrato em S. Tomé e Príncipe nos séculos XIX e XX: sujeição e ética laboral'. Africana Studia 7: 183-217.

Navarro, Joaquín J. 1859. Apuntes sobre el estado de la costa occidental de Africa y principalmente de las posesiones españoles en el Golfo de Guinea. Madrid: Impr. Nacional.

Nerín, Gustau. 2008. Un guardia civil en la selva. Barcelona: Ariel.

—. 2009. 'La soberanía española en el Muni (1900-1914)'. In, 23-54. Madrid: Los Libros de la Catarata.

- 2009. 'Socialismo utópico y tiranía: La isla de Annobón bajo el cabo Restituto Castilla (1931-1932)'. Afro-Hispanic Review 28 (2): 311-30. 
- 2010. La última selva de España: antropófagos, misioneros y guardias civiles: crónica de la conquista de los Fang de la Guinea española, 1914-1930. Madrid: Los Libros de la Catarata.

- 2013. 'Y el cabo Nacarino tenía una guitarra... Investigando la conquista del Muni'. In Perspectivas antropológicas sobre Guinea Ecuatorial, edited by Juan Aranzadi Martínez and Paz Moreno Feliu, 189-201. Madrid: UNED.

Nerín, Gustau, and Alfred Bosch. 2001. El imperio que nunca existió: la aventura colonial discutida en Hendaya. Barcelona: Plaza \& Janés Editores.

Nevinson, Henry Woodd. 1906. A Modern Slavery. London: Harper \& Brothers.

Newell, Stephanie. 2013. The Power to Name: A History of Anonymity in Colonial West Africa. Athens: Ohio University Press.

Newton-King, Susan. 1980. 'The Labour Market of the Cape Colony, 1807-28'. In Economy and Society in Pre-Industrial South Africa, edited by Anthony Atmore and Shula Marks, 198:173-200. London: Longman.

Nieboer, Herman J. 1971[1900]. Slavery as an Industrial System: Ethnological Research. New York: B. Franklin.

Nkem-Onyekpe, Justin G. 2008. 'Trade as Exploitation: Perspectives on the Political Economy of Colonial West Niger Igbo Area, C. 1886-1930'. Lagos Historical Review 8: 1-19.

North-Coombes, M. D. 1984. 'From Slavery to Indenture: Forced Labour in the Political Economy of Mauritius, 1834-1867'. In Indentured Labour in the British Empire, 1834-1920, edited by Kay Saunders, 1920:78-125. London: Croom Helm.

Northrup, David. 1976. 'The Compatibility of the Slave and Palm Oil Trades in the Bight of Biafra'. The Journal of African History 17 (3): 353-64.

. 1995. Indentured Labor in the Age of Imperialism, 1834-1922. Cambridge: Cambridge University Press. 
2002. 'Freedom and Indentured Labor in the French Caribbean, 1848-1900'.

In Coerced and Free Migration: Global Perspectives, edited by David Eltis, 205-28. Stanford: Stanford University Press.

. 2003. 'Free and Unfree Labor Migration, 1600-1900: An Introduction'. Journal of World History 14 (2): 125-30.

Nosti Nava, Jaime. 1942. Notas geográficas, fisicas y económias sobre los territorios españoles del Golfo de Guinea. Madrid: Espasa-Calpe.

1948. Agricultura de Guinea, promesa para España. Madrid: Instituto de Estudios Africanos.

-1955. La agricultura en Guinea española. Instituto de Estudios Africanos. Madrid: Instituto de Estudios Africanos.

Nsue Mibui, Rosendo-Ela. 2007. Historia de la colonización y la descolonización de Guinea Ecuatorial por España. Madrid: Gràficas Algoran.

Nwabughuogu, Anthony I. 1982. 'From Wealthy Entrepreneurs to Petty Traders: The Decline of African Middlemen in Eastern Nigeria, 1900-1950'. The Journal of African History 23 (03): 365-79.

_ 1984. 'The "Isusu": An Institution for Capital Formation among the Ngwa Igbo; Its Origin and Development to 1951'. Africa: Journal of the International African Institute 54 (4): 46-58.

Nwokeji, G. Ugo. 1998. 'The Slave Emancipation Problematic: Igbo Society and the Colonial Equation'. Comparative Studies in Society and History 40 (2): 318-55.

- 2010. The Slave Trade and Culture in the Bight of Biafra: An African Society in the Atlantic World. New York: Cambridge University Press.

Obadare, Ebenezer. 2001. 'Constructing Pax Nigeriana? The Media and Conflict in Nigeria-Equatorial Guinea Relations'. Nordic Journal of African Studies 10 (1): 80-89. 
2003. 'Nigeria-Equatorial Guinea Relations since 1927: A Critique of the

Historiography'. In The Foundations of Nigeria: Essays in Honor of Toyin Falola, edited by Toyin Falola, 575-89. Trenton: Africa World Press.

O'Connell Davidson, Julia. 2015. Modern Slavery: The Margins of Freedom (New York: Palgrave Macmillan, 2015).

Offiong, Daniel A. 1984. 'The Functions of the Ekpo Society of the Ibibio of Nigeria'. African Studies Review 27 (3): 77-92.

Ofonagoro, Walter I. 1979. Trade and Imperialism in Southern Nigeria 1881-1929. New York: NOK.

. 1982. 'An Aspect of British Colonial Policy in Southern Nigeria: The Problems of Forced Labour and Slavery, 1895-1928'. In Studies in Southern Nigerian History, edited by Boniface Obichere, 219-44. London: Frank Cass.

Ojo, Olatunji. 2007. “Ėmú” (Àmúyá): The Yoruba Institution of Panyarring or Seizure for Debt'. African Economic History 35: 31-58.

_. 2012. 'The Southern Nigeria Native House Rule Ordinance (1901)'. African Economic History 40: 127-36.

_ 2013. 'The Atlantic Slave Trade and Local Ethics of Slavery in Yorubaland'. African Economic History 41 (1): 73-100.

Okolie, Andrew C. 2003. 'The Transformation of Eastern Nigeria: From Self Sufficiency to Social Crisis'. In The Foundations of Nigeria: Essays in Honor of Toyin Falola, edited by Toyin Falola, 449-72. Trenton: Africa World Press.

Olukoju, Ayodeji. 2000. 'Confronting the Combines: Producers' and Traders' Militancy in Western Nigeria'. Nordic Journal of African Studies 9 (1): 49-69.

Orde-Browne, G. St. J. 1941. Labour Conditions in West Africa. London: H. M. Stationary Office.

. 1967. The African Labourer. London: Routledge. 
Oriji, John N. 1983. 'A Study of the Slave and Palm Produce Trade amongst the NgwaIgbo of Southeastern Nigeria.' Cahiers d'Études Africaines 23 (91): 311-28.

Oroge, E. Adeniyi. 1985. 'Iwofa: An Historical Survey of the Yoruba Institution of Indenture'. African Economic History 14: 75-106.

Ortiz, Fernando. 1916. La lampa afro-cubano: Los negros esclavos. Havana: Ruis.

Ortiz, Sutti. 2002. 'Laboring in the Factories and in the Fields'. Annual Review of Anthropology 31: 395-417.

Osoba, Segun. 1969. 'The Phenomenon of Labour Migration in the Era of British Colonial Rule: A Neglected Aspect of Nigeria's Social History'. Journal of the Historical Society of Nigeria 4 (4): 515-38.

Osuntokun, Akinjide. 1978. Equatorial Guinea Nigerian Relations: The Diplomacy of Labour. Lagos: Oxford University Press.

1978. 'Relations Between Nigeria and Fernando Po from Colonial Times to the Present'. In Nigeria and the World: Readings in Nigerian Foreign Policy, edited by Bolaji Akinyemi, 1-16. Ibadan: Ibadan University Press.

_ 1992. 'The Dynamics of Nigerian- Equatorial Guinea Relations from Colonial Times to the Present'. In Nigeria and Its Immediate Neighbours: Constraints and Prospects of Sub-Regional Security in the 1990s, edited by B. Ate and B. Akinterinwa. Lagos: Punmark.

Ots, José Maria. 1941. 'El “tributo” en la epoca colonial'. El Trimestre Económico 7 (28): 586-615.

Ottenberg, Simon. 2006. Igbo Religion, Social Life, and Other Essays. Edited by Toyin Falola. Trenton: Africa World Press.

Ottenberg, Simon, and Phoebe Ottenberg. 1962. 'Afikpo Markets: 1900-1960'. In Markets in Africa, edited by Paul Bohannan and George Dalton, 118-69. Chicago: Northwestern University Press. 
Padmore, George. 1938. 'West Africans Watch Your Land'. International African Opinion 1 (3): 11-16.

Pateman, Carole. 1988. The Sexual Contract. Stanford: Stanford University Press.

Patterson, Orlando. 1982. Slavery and Social Death: A Comparative Study. Cambridge: Harvard University Press.

Peebles, Gustav. 2014. 'Rehabilitating the Hoard: The Social Dynamics of Unbanking in Africa and Beyond'. Africa 84 (4): 595-613.

Pélissier, René. 1964. Los territorios españoles de Africa. Madrid: Consejo Superior de Investigaciones Científicas.

Pérez de la Riva, Juan. 2000. Los culies chinos en Cuba, 1847-1880: contribución al estudio de la inmigración contratada en el Caribe. La Habana: Editorial de Ciencias Sociales.

Perpiñá Grau, Román. 1945. De colonización y economía en la Guinea española: investigación, sobre el terreno, de la estructura y sistema de colonización en la Guinea española, con referencia especial a lo económico, precedido de un estudio general de los territorios africanos. Barcelona: Tall. Ibero Americanos.

. 1947. 'Mano de obra africana, factor de coste colonial: investigación sobre el peso de los braceros contratados en Fernando Poo'. Cuadernos de Estudios Africanos 3: 127-44.

Peters, Edward. 1998. 'Prison before the Prison: The Ancient and Mideval World'. In The Oxford History of the Prison: The Practice of Punishment in Western Society, edited by Norval Morris, 3-43. Oxford: Oxford University Press.

Petit Calvo, Carlos. 1998. 'Detrimentum rei publicae: Constitución de España en Guinea'. In Constitución en España: orígenes y destinos, edited by José María Portillo Valdés and José María Iñurritegui Rodríguez, 425-94. Madrid: Centro de Estudios Políticos y Constitucionales.

—. 2001. 'Detrrimentum Rei Publicae. Die spanische "Verfassung” in Guinea'. Jahrbuch für Europäische Geschichte 2: 147-90. 
2007. 'The Colonial Model of the Rule of Law in Africa: The Example of Guinea'. In The Rule of Law: History, Theory and Criticism, edited by Pietro Costa, Danilo Zolo, and Emilio Santoro, 467-512. Dordrecht: Springer.

Phillips, Anne. 1989. The Enigma of Colonialism: British Policy in West Africa. London: J. Currey.

Pike, Ruth. 1983. Penal Servitude in Early Modern Spain. Madison: University of Wisconsin Press.

Piqueras Arenas, José Antonio. 2002. 'El capital emancipado: Esclavitud, industria azucarera y abolición en Cuba'. In Azúcar y esclavitud en el final del trabajo forzado, edited by José Antonio Piqueras Arenas, 11-33. Mexicó: Fondo de Cultura Economica.

Pozanco, Ángel Miguel. 1937. Guinea mártir: Narraciones, notas y comentarios de un condenado a muerte. Barcelona: Colección Actualidad.

Prakash, Gyan. 1990. Bonded Histories: Genealogies of Labor Servitude in Colonial India. Cambridge: Cambridge University Press.

- 1997. 'Colonialism, Capitalism and the Discourse of Freedom'. In Peripheral Labour: Studies in the History of Partial Proletarianization, edited by Marcel van der Linden and Shahid Amin, 9-25. Cambridge: Cambridge University Press.

Pratten, David. 2007. The Man-Leopard Murders: History and Society in Colonial Nigeria. Edinburgh: Edinburgh University Press.

Quirk, Joel. 2012. 'Defining Slavery in All Its Forms: Historical Inquiry as Contemporary Instruction'. In The Legal Understanding of Slavery, edited by J. Allain, 253-278 (Oxford: Oxford University Press, 2012).

Ravi Raman. 2010. Global Capital and Peripheral Labour: The History and Political Economy of Plantation Workers in India. London: Routledge.

Ramasamy, Palanisamy. 1992. 'Labour Control and Labour Resistance in the Plantations of Colonial Malaya'. Journal of Peasant Studies 19 (3/4): 87-105. 
Ramírez Copeiro del Villar, Jesús. 2004. Objetivo África: crónica de la Guinea española en la II Guerra Mundial. Valverde del Camino: self-published.

Ramos Izquierdo y Vivar, Luis, and Eduardo Navarro y Beltran del Rio. 1912. Descripción geográfica y gobierno, administración y colonización de las colonias españolas del golfo de Guinea. Madrid: Felipe Peña Cruz.

Rao, J. Mohan. 1999. 'Freedom, Equality, Property and Bentham: The Debate Over Unfree Labour'. The Journal of Peasant Studies 27 (1): 97-127.

Ray, Carina E. 2012. 'Sex Trafficking, Prostitution, and the Law in Colonial British West Africa, 1911-43'. In Trafficking in Slavery's Wake: Law and the Experience of Women and Children in Africa, edited by K. Bales, J. Sarich, B. N. Lawrance, and R. L. Roberts, 100-120. Athens: Ohio University Press.

Reid, Anthony, and Jennifer Brewster. 1983. Slavery, Bondage, and Dependency in Southeast Asia. New York: St. Martin's Press.

Renault, François. 1976. Libération d'esclaves et nouvelle servitude: les rachats de captifs africains pour le compte des colonies françaises après l'abolition de l'esclavage. Abidjan: Les Nouvelles Éditions Africaines.

Richardson, David, and Paul E. Lovejoy. 1995. 'The Initial "Crisis of Adaptation": The Impact of British Abolition on the Atlantic Slave Trade in West Africa, 18081820'. In From Slave Trade to 'Legitimate' Commerce, edited by Robin Law, 32-56. Cambridge: Cambridge University Press.

Richardson, Peter. 1977. 'The Recruiting of Chinese Indentured Labour for the South African Gold-Mines, 1903-1908'. The Journal of African History 18 (1): 85108.

_ 1982. Chinese Mine Labour in the Transvaal. London: Macmillan Press.

Rich, Jeremy M. 2007. A Workman Is Worthy of His Meat: Food and Colonialism in the Gabon Estuary. Lincoln: University of Nebraska Press.

Ríos, Mateo. 1959. La España ignorada. Barcelona: Hispano Europea. 
Rodney, Walter. 1966. 'African Slavery and Other Forms of Social Oppression on the Upper Guinea Coast in the Context of the Atlantic Slave-Trade'. The Journal of African History 7 (3): 431-43.

Rodríguez Barrera, Joaquín. 1924. Manual del agricultor en Fernando Póo: El cacao. Barcelona: Artes gráficas.

Rodríguez Pastor, Humberto. 1989. Hijos del Celeste Imperio en el Perú (1850-1900): migración, agricultura, mentalidad y explotación. Lima: Instituto de Apoyo Agrario.

Rodríguez Piña, Javier. 1990. Guerra de castas: la venta de indios mayas a Cuba, 1848-1861. México, D.F.: Consejo Nacional para la Cultura y las Artes.

Rogers, Nicholas. 2012. 'Vagrancy, Impressment and the Regulation of Labor in Eighteenth Century Britain'. In Unfree Labour in the Development of the Atlantic World, edited by Paul E. Lovejoy and Nicholas Rogers, 102-14. London: Routledge.

Roitman, Janet. 2004. Fiscal Disobedience: An Anthropology of Economic Regulation in Central Africa. Princeton: Princeton University Press.

Romero Moliner, Rafael. 1949. 'Apuntes sobre la estructura social de Fernando Poo'. Cuadernos de Estudios Africanos 7: 23-52.

1950. ‘Crónica de Guinea'. Cuadernos de Estudios Africanos 10: 86-88.

—. 1952. 'Crónica de los territorios de Guinea'. Cuadernos de Estudios Africanos 17: 90-92.

Röschenthaler, Ute. 2002. 'A New York City of Ibibioland?: Local Historiographies and Power Conflict in Calabar'. In A Place in the World: New Local Historiographies from Africa and South Asia, edited by Axel Harneit-Sievers, 87-110. Leiden: Brill.

Roy, Tirthankar. 2008. 'Sardars, Jobbers, Kanganies: The Labour Contractor and Indian Economic History'. Modern Asian Studies 42 (5): 971-98. 
Rudin, Harry R. 1968. Germans in the Cameroons, 1884-1914: A Case Study in Modern Imperialism. Hamden: Archon Books.

Rüger, Adolf. 1960. 'Die Entstehung und Lage der Arbeiterklasse unter dem deutschen Kolonialregime in Kamerun (1895-1905)'. In Kamerun unter deutscher Kolonialherrschaft: Studien, edited by Helmuth Stoecker, 1:149-242. Berlin: Rütten \& Loening.

Ruiz-Esquide Figueroa, Andrea. 1999. 'Chilean Rural Labor in the Nineteenth Century. A Historiographical Essay.' Anuario de Historia de América Latina 36: 349-75.

Sampedro Vizcaya, Benita. 2008. 'Rethinking the Archive and the Colonial Library: Equatorial Guinea'. Journal of Spanish Cultural Studies 9: 321-41.

_. 2009. 'Theorizing Equatorial Guinea'. Afro-Hispanic Review 28 (2): 15-19.

—. 2012. 'Engaging the Atlantic: New Routes, New Responsibilities'. Bulletin of Hispanic Studies 89 (8): 905-22.

Sant Gisbert, Jordi. 2009. 'El modelo económico colonial y sus contradicciones: Fernando Poo (1900-1936)'. Afro-Hispanic Review 28 (2): 57-80.

Santiago-Valles, Kelvin A. 1996. 'Forcing Them to Work and Punishing Whoever Resisted: Servile Labor and Penal Servitude under Colonialism in Nineteenth Century Puerto Rico'. In The Birth of the Penitentiary in Latin America, edited by Carlos Aguirre and Ricardo D. Salvatore, 123-68. Austin: University of Texas Press.

Sanz Casas, Gonzal. 1984. 'Los finqueros y el uso del trabajo forzado en la agricultura colonial de la isla de Fernando Poo'. Arxiu d'Etnografia de Catalunya 3: 12336.

Schapera, Isaac. 1947. Migrant Labour and Tribal Life, a Study of Conditions in the Bechuanaland Protectorate. London: Oxford University Press.

Schuler, Monica. 1986. 'Kru Emigration to British and French Guiana, 1841-1857'. In Africans in Bondage: Studies in Slavery and the Slave Trade, edited by Philip 
D. Curtin and Paul E. Lovejoy, 155-201. Madison: University of Wisconsin Press.

1986. 'The Recruitment of African Indentured Labourers for European Colonies in the Nineteenth Century'. In Colonialism and Migration: Indentured Labour Before and After Slavery, edited by Peter Emmer, 125-60. New York: Springer.

Scott, Christopher D. 1976. 'Peasants, Proletarianization and the Articulation of Modes of Production: The Case of Sugar Cane Cutters in Northern Peru, 1940-69'. Journal of Peasant Studies 3 (3): 321-42.

Scott, Rebecca J. 1985. Slave Emancipation in Cuba: The Transition to Free Labor, 1860-1899. Princeton: Princeton University Press.

- 2009. Degrees of Freedom: Louisiana and Cuba after Slavery. Harvard: Harvard University Press.

Seibert, Gerhard. 2006. Comrades, Clients and Cousins: Colonialism, Socialism and Democratization in São Tomé and Príncipe. Leiden: Brill.

Sekula, Allan. 1986. 'The Body and the Archive'. October 39: 3-64.

Sen, Samita. 1999. Women and Labour in Late Colonial India the Bengal Jute Industry. Cambridge: Cambridge University Press.

- 2010. 'Commercial Recruiting and Informal Intermediation: Debate Over the Sardari System in Assam Tea Plantations, 1860-1900'. Modern Asian Studies 44 (1): 3-28.

Sen, Soumen. 2004. Khasi-Jaintia Folklore: Context, Discourse, and History. Chennai: National Folklore Support Centre.

Sepa Bonota, Edmundo. 2011. España en la isla de Fernando Poo, 1843-1968: Colonización y fragmentación de la sociedad bubi. Barcelona: Icaria.

Serres, Michel, and Bruno Latour. 1995. Conversations on Science, Culture, and Time. Ann Arbor: University of Michigan Press. 
Shapiro, Carl, and Joseph E. Stiglitz. 1984. 'Equilibrium Unemployment as a Worker Discipline Device'. The American Economic Review 74 (3): 433-44.

Shepherd, Verene A. 2002. "The Other Middle Passage?" Nineteenth-Century Bonded Labour Migration and the Legacy of the Slavery Debate in the BritishColonized Caribbean'. In Working Slavery, Pricing Freedom: Perspectives from the Caribbean, Africa and the African Diaspora, edited by Verene A. Shepherd, 343-377. New York: Palgrave.

Shivji, Issa G. 1979. Semi-Proletarian Labour and the Use of Penal Sanctions in the Labour Law of Colonial Tanganyika (1920-1938). [s.1.]: [s.n.].

Singha, Radhika. 2000. 'Settle, Mobilize, Verify: Identification Practices in Colonial India'. Studies in History 16 (2): 151-98.

Sinha, Nitin. 2014. 'Contract, Work, and Resistance: Boatmen in Early Colonial Eastern India, 1760s-1850s'. International Review of Social History 59 (S22): $11-43$.

Smith, Robert. 1974. 'The Lagos Consulate, 1851-1861: An Outline'. The Journal of African History 15 (3): 393-416.

Soumonni, Elisee. 1995. 'The Compatibility of the Slave and Palm Oil Trades in Dahomey, 1818-1858'. In From Slave Trade to 'Legitimate' Commerce, edited by Robin Law, 78-92. Cambridge: Cambridge University Press.

Spener, David. 2009. Clandestine Crossings: Migrants and Coyotes on the TexasMexico Border. New York: Cornell University Press.

Stanley, Amy Dru. 1998. From Bondage to Contract: Wage Labor, Marriage, and the Market in the Age of Slave Emancipation. Cambridge: Cambridge University Press.

Stanziani, Alessandro. 2012. Labour, Coercion, and Economic Growth in Eurasia, 17th-20th Centuries. Leiden: Brill. 
- 2013. 'Beyond Colonialism: Servants, Wage Earners and Indentured Migrants in Rural France and on Reunion Island (c. 1750-1900)'. Labor History 54 (1): 64-87.

- 2013. 'Local Bondage in Global Economies: Servants, Wage Earners, and Indentured Migrants in Nineteenth-Century France, Great Britain, and the Mascarene Islands'. Modern Asian Studies 47 (4): 1218-51.

-2014. Bondage: Labor and Rights in Eurasia from the Sixteenth to the Early Twentieth Centuries. New York: Berghahn Books.

Steinfeld, Robert J. 2001. Coercion, Contract, and Free Labor in the Nineteenth Century. New York: Cambridge University Press.

Stevenson, J. 1971. 'The London "Crimp" Riots of 1794'. International Review of Social History 16 (1): 40-58.

Stichter, Sharon. 1985. African Society Today: Migrant Laborers. Cambridge: Cambridge University Press.

Stoecker, Helmuth. 1986. 'Cameroon 1880-1906'. In German Imperialism in Africa: From the Beginnings Until the 2nd World War, edited by Helmuth Stoecker, 6283. Berlin: Akademie-Verlag.

- 1986. 'Cameroon 1906-1914'. In German Imperialism in Africa: From the Beginnings Until the 2nd World War, edited by Helmuth Stoecker, 161-74. London: Hurst.

Stoler, Ann Laura. 1995. Capitalism and Confrontation in Sumatra's Plantation Belt, 1870-1979. Ann Arbor: University of Michigan Press.

- 2008. Along the Archival Grain: Epistemic Anxieties and Colonial Common Sense. Princeton: Princeton University Press.

Stoler, Ann Laura, and Carole McGranahan. 2007. 'Imperial Formations'. In Imperial Formations, edited by Peter C. Perdue, Ann Laura Stoler, and Carole McGranahan, 3-42. Santa Fe: School for Advanced Research Press. 
Sundiata, Ibrahim. 1974. 'Prelude to Scandal: Liberia and Fernando Po, 1880-1930'. The Journal of African History 15 (1): 97-112.

—. 1975. 'The Rise and Decline of Kru Power: Fernando Po in the 19th Century'. Liberian Studies Journal 6 (1): 25-43.

. 1990. Equatorial Guinea: Colonialism, State Terror, and the Search for Stability. Oxford: Westview Press.

- 1996. From Slaving to Neoslavery: The Bight of Biafra and Fernando Po in the Era of Abolition, 1827-1930. Wisconsin: University of Wisconsin Press.

- 2004. Brothers and Strangers: Black Zion, Black Slavery, 1914-1940. Durham: Duke University Press.

Talbot, Percy A. 1923. Life in Southern Nigeria the Magic, Beliefs, and Customs of the Ibibio Tribe. London: Macmillan and Co. limited.

- 1969. The Peoples of Southern Nigeria: A Sketch of Their History, Ethnology and Languages, with an Abstract of the 1921 Census. London: Frank Cass.

Tapela, Henderson M. 1985. 'Nigerian Labour for Fernando Po'. The Calabar Historical Journal 3 (1): 36-56.

- 1990. 'The Cross River Basin. Colonial Labour Policies and Practices'. In $A$ History of the Cross River Region of Nigeria, edited by Monday B. Abasiattai, 198-214. Calabar: University of Calabar Press.

Taussig, Michael. 1991. Shamanism, Colonialism, and the Wild Man: A Study in Terror and Healing. Chicago: University of Chicago Press.

Tavares, Luís Henrique Dias. 1988. 'O capitalismo no comércio proibido de escravos'. Revista do Instituto de Estudos Brasileiros 28: 37-52.

Terán, Manuel de. 1962. Síntesis geográfica de Fernando Poo. Madrid: Consejo Superior de Investigaciones Científicas. 
Thomas, Hugh. 1997. The Slave Trade: The Story of the Atlantic Slave Trade, 14401870. New York: Simon and Schuster.

Thorner, Alice. 1982. 'Semi-Feudalism or Capitalism? Contemporary Debate on Classes and Modes of Production in India'. Economic and Political Weekly 17 (59): 2061-66.

Tinker, Hugh. 1974. A New System of Slavery: The Export of Indian Labour Overseas, 1830-1920. London: Oxford University Press.

Tomich, Dale W. 2004. Through the Prism of Slavery: Labor, Capital, and World Economy. Lanham: Rowman \& Littlefield.

Tonkin, Elizabeth. 1985. 'Creating Kroomen: Ethnic Diversity, Economic Specialism and Changing Demand'. In Africa and the Sea: Proceedings of a Colloquium at the University of Aberdeen, March 1984, edited by Jeffrey C. Stone, 27-47. Aberdeen: University of Abderdeen.

Trebilcock, Micahel J. 1993. The Limits of Freedom of Contract. Cambridge: Harvard University Press.

Turner, Mary. 1995. From Chattel Slaves to Wage Slaves: The Dynamics of Labour Bargaining in the Americas. Bloomington: Indiana University Press.

Uchendu, Victor C. 1979. 'Slaves and Slavery in Iboland, Nigeria'. In Slavery in Africa: Historical and Anthropological Perspectives, edited by Suzanne Miers and Igor Kopytoff, 121-32. Wisconsin: University of Wisconsin Press.

Udoma, Udo. 1987. The Story of the Ibibio Union: Its Background, Emergence, Aims, Objectives, and Achievements. Ibadan: Spectrum Books.

Ukwu, Ukwu I. 1967. 'The Development of Trade and Marketing in Iboland'. Journal of the Historical Society of Nigeria 3 (4): 647-62.

Vahed, Goolam. 2014. 'Power and Resistance: Indentured Labour in Colonial Natal, 1860-1911'. In Resistance and Indian Indenture Experience. Comparative Perspectives, edited by Maurits S. Hassankhan, Brij V. Lal, and Doug Munro, 95-120. Delhi: Manohar. 
Vail, Leroy, and Landeg White. 1980. Capitalism and Colonialism in Mozambique: A Study of Quelimane District. Minneapolis: University of Minnesota Press.

van den Bersselaar, Dmitri. 1997. "Creating "Union Ibo": Missionaries and the Igbo Language'. Africa: Journal of the International African Institute 67 (2): 27395.

—. 2014. "“Somebody Must Necessarily Go to Bring This Drink”: Gin Smugglers, Chiefs and the State in Colonial Ghana'. Cultural and Social History 11 (2): 243-61.

van der Linden, Marcel. 2008. Workers of the World: Essays Toward a Global Labor History. Leiden: Brill.

van der Linden, Marcel, and Leo Lucassen. 2012. Working on Labor: Essays in Honor of Jan Lucassen. Leiden: Brill.

van Onselen, Charles. 1976. Chibaro: African Mine Labour in Southern Rhodesia, 1900-1933. London: Pluto Press.

van Schendel, Willem. 2006. 'Stretching Labour Historiography: Pointers from South Asia'. International Review of Social History 51 (S14): 229-61.

Varma, Nitin. 2005. 'Coolie Acts and the Acting Coolies: Coolie, Planter and State in the Late Nineteenth and Early Twentieth Century Colonial Tea Plantations of Assam'. Social Scientist 33 (5/6): 49-72.

Vaughan, Megan. 2005. Creating the Creole Island: Slavery in Eighteenth-Century Mauritius. Duke: Duke University Press.

Velarde Fuentes, Juan. 1964. 'Problemas de empleo en la Guinea Ecuatorial'. Revista de Trabajo 2 (1): 141-77.

Vos, Jelmer. 2012. "Without the Slave Trade, No Recruitment”: From Slave Trading to "Migrant Recruitment" in the Lower Congo, 1830-90'. In Trafficking in Slavery's Wake: Law and the Experience of Women and Children in Africa, edited by Benjamin N. Lawrance and Richard L. Roberts. Athens: Ohio University Press. 
Walker, Harry. 2012. 'Demonic Trade: Debt, Materiality, and Agency in Amazonia'. Journal of the Royal Anthropological Institute 18 (1): 140-59.

Wallerstein, Immanuel. 1979. The Capitalist World-Economy. Cambridge: Cambridge University Press.

Wareing, John. 2001. "Violently Taken Away or Cheatingly Duckoyed": The Illicit Recruitment in London of Indentured Servants for the American Colonies, 1645-1718'. The London Journal 26 (2) 1-22.

Wariboko, Nimi. 1998. 'A Theory of the Canoe House Corporation'. African Economic History 26: 141-72.

Watson, James L. 1980. 'Transactions in People: The Chinese Market in Slaves, Servants and Heirs'. In Asian and African Systems of Slavery, edited by James L. Watson, 223-51. Berkeley: University of California Press.

Weber, Max. 1968. Economy and Society: an Outline of Interpretive Sociology. New York: Bedminster Press.

Wharton, Barrie. 2006. 'The Impact and Legacy of Twentieth-Century Spanish Colonial Policy on the Socio-Political Development of Guinea Ecuatorial'. Journal of African Studies 3 $(1)$, http://hdl.handle.net/2027/spo.4761563.0003.102.

Wieschhoff, Heinrich A. 1944. Colonial Policies in Africa. Philadelphia: University of Pennsylvania Press.

Williams, Eric E. 1944. Capitalism and Slavery. Chapel Hill: University of North Carolina Press.

Wilson, Francis. 1972. Labour in the South African Gold Mines 1911-1969. Cambridge: Cambridge University Press.

Winkler, Hella. 1960. 'Das Kameruner Proletariat, 1906-1914'. In Kamerun unter Deutscher Kolonialherrschaft: Studien, edited by Helmuth Stoecker, 1:250290. Berlin: Rütten \& Loening. 
Wirz, Albert. 1972. Vom Sklavenhandel zum kolonialen Handel: Wirtschaftsräume und Wirtschaftsformen in Kamerun vor 1914. Freiburg: Atlantis.

Wolf, Eric. 1982. Europe and the People Without History. Berkeley: University of California Press.

Wolff, Günther. 1942. 'Ein Beitrag Zur Wirtschaft von Fernando Poo'. Beiträge Zur Kolonialforschung 1: 93-110.

Woolbert, Robert Gale. 1946. 'Spain as an African Power'. Foreign Affairs 24 (4): $723-$ 35.

Worger, William H. 1987. South Africa's City of Diamonds: Mine Workers and Monopoly Capitalism in Kimberley, 1867-1895. New Haven: Yale University Press.

Xavier, Adro. 1960. España en Africa: Ayer y hoy. Barcelona: Ferma.

Yglesias de La Riva, Angel. 1947. Politica indígena en Guinea. Madrid: Instituto de Estudios Africanos.

Yun, Lisa. 2008. The Coolie Speaks: Chinese Indentured Laborers and African Slaves in Cuba. Philadelphia: Temple University Press.

Zarco, Mariano. 1938. Dialecto inglés-africano o, Broken-English de la colonia española del Golfo de Guinea. 2. ed. Turnhout Bélgica: Impr. H. Proost.

Zavala, Silvio. 1944. 'Origenes coloniales del peonaje en México'. El Trimestre Económico 10 (40): 711-48. 


\section{Unpublished Theses}

García Cantús, Dolores. 2004. 'Fernando Poo: Una aventura colonial española en el África Occidental (1778-1900)'. PhD Thesis, Valencia: Universitat de València.

Kobel, Armin. 1976. 'La République de Guinée Equatoriale: Ses ressources potentielles et virtuelles et les possibilités de son développement'. PhD Thesis, Neuchâtel: Université de Neuchâtel.

MacDonald, Andrew. 2012. 'Colonial Trespassers in the Making of South Africa's International Borders 1900 to C. 1950'. PhD Thesis, Cambridge: St John's College.

Morrill, Warren T. 1961. 'Two Urban Cultures of Calabar, Nigeria'. PhD Thesis, Chicago: University of Chicago.

Oham, Anthony C. 2006. 'Labor Migration from Southeastern Nigeria to Spanish Fernando Po, 1900-1968'. MA Thesis, Chicago: Central Michigan University.

Okenve Martinez, Enrique Sang. 2007. 'Equatorial Guinea 1927-1979: A New African Tradition'. PhD Thesis, London: SOAS.

Oriji, John N. 1987. 'A History of Ngwa People: Social and Economic Developments in an Igloo Clan from the 13th to the 20th Centuries'. PhD Thesis, New Jersey: Rutgers University.

Ruiz Benitez, Demetrio. 1970. 'Guinea Española: Economía de la colonia y estudio especial de su comercio exterior'. MA Thesis, Madrid: Escuela Central Superior de Comercio.

Sanz Casas, Gonzal. 1983. 'Política colonial y organización del trabajo en la isla de Fernando Poo: 1880-1930'. PhD Thesis, Barcelona: Universidad de Barcelona. 1975. 'Problemas de una agricultura colonial: Los territorios españolas del Golfo de Guinea, 1940-1960'. MA Thesis, Barcelona: Universidad Autonoma Barcelona. 
Simmons, Donald C. 1957. 'Analysis of the Reflection of Culture in Efik Folktales'. PhD Thesis, New Haven: Yale University.

Sundiata, Ibrahim. 1972. 'The Fernandinos: Labor and Community in Santa Isabel de Fernando Poo, 1827-1931'. PhD Thesis, Evanston: Northwestern University.

Turay, Abdul Karim. 1971. 'Loanwords in Temne: A Study of the Sources and Processes of Lexical Borrowing in a Sierra Leonean Language'. PhD Thesis, London: SOAS.

Varma, Nitin. 2011. 'Producing Tea Coolies?: Work, Life and Protest in the Colonial Tea Plantations of Assam, 1830s-1920s'. PhD Thesis, Berlin: Humboldt University of Berlin. 


\section{Appendix: Graphs and Tables}

Cacao and coffee exports from Spanish Guinea, 1884-1975. ${ }^{1}$

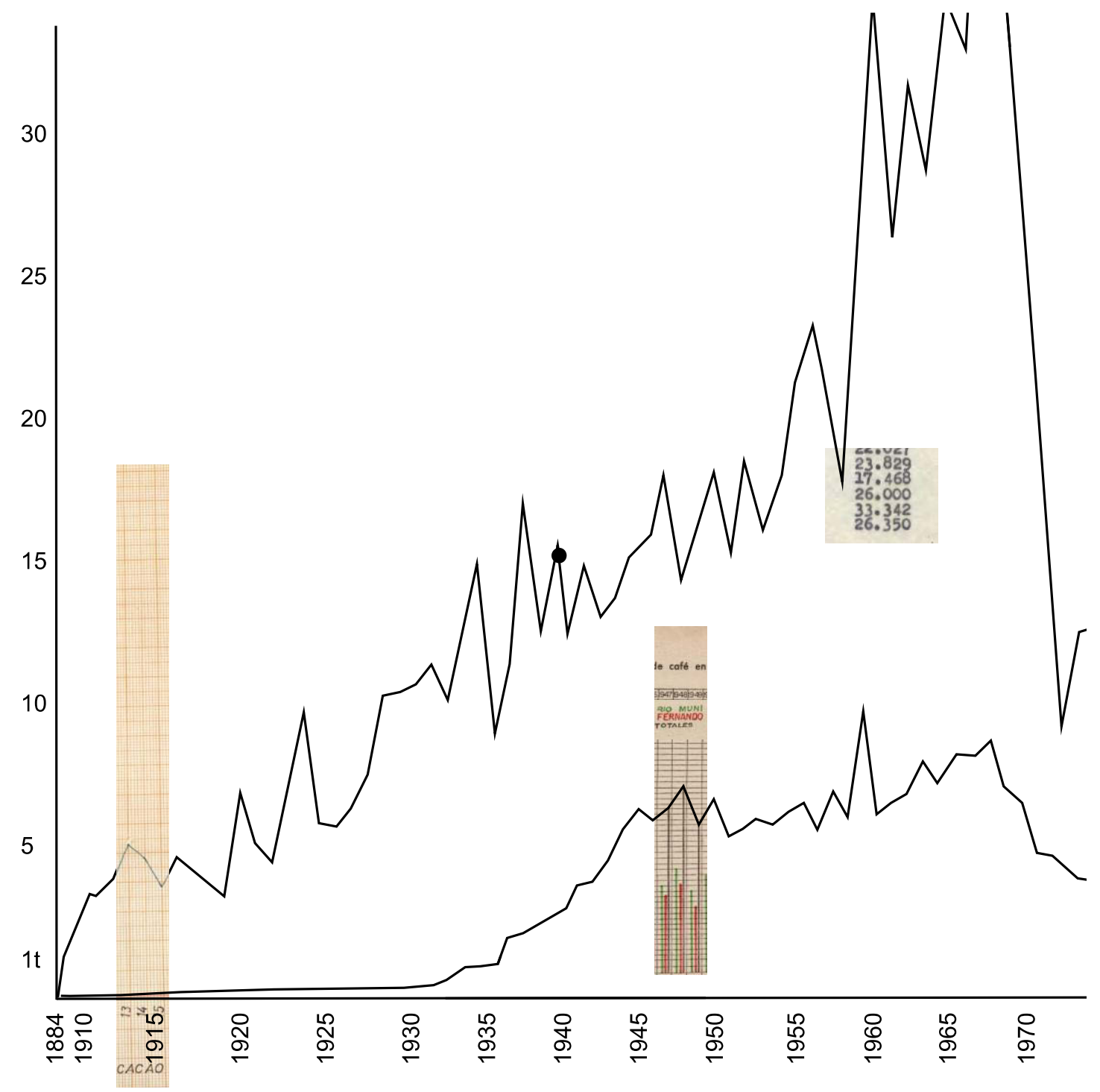

${ }^{1}$ Between $80 \%$ and $100 \%$ of the cacao was from Fernando Pó. A little over half the coffee was from Rio Muni. Data: Bravo, Fernando Póo, 129; Kobel, 'La République de Guinée Equatoriale', 195, 268; Jakobeit, 'Äquatorialguinea', 150; Inset of images from left to right, Sanz Casas, 'Problemas de una agricultura colonial', Appendix; MAE, 10 March 1962, 'Desarollo de la economía en Fernando Poo', AGA, C-81/13039, E-392; Delegación Peninsular para Café de las Camaras Oficiales Agricolas de Guinea, 'Memoria del año 1971', Appendix. 
Demographic arch of Bubi and non-Bubi population on Fernando Pó, 1850-1968. ${ }^{2}$

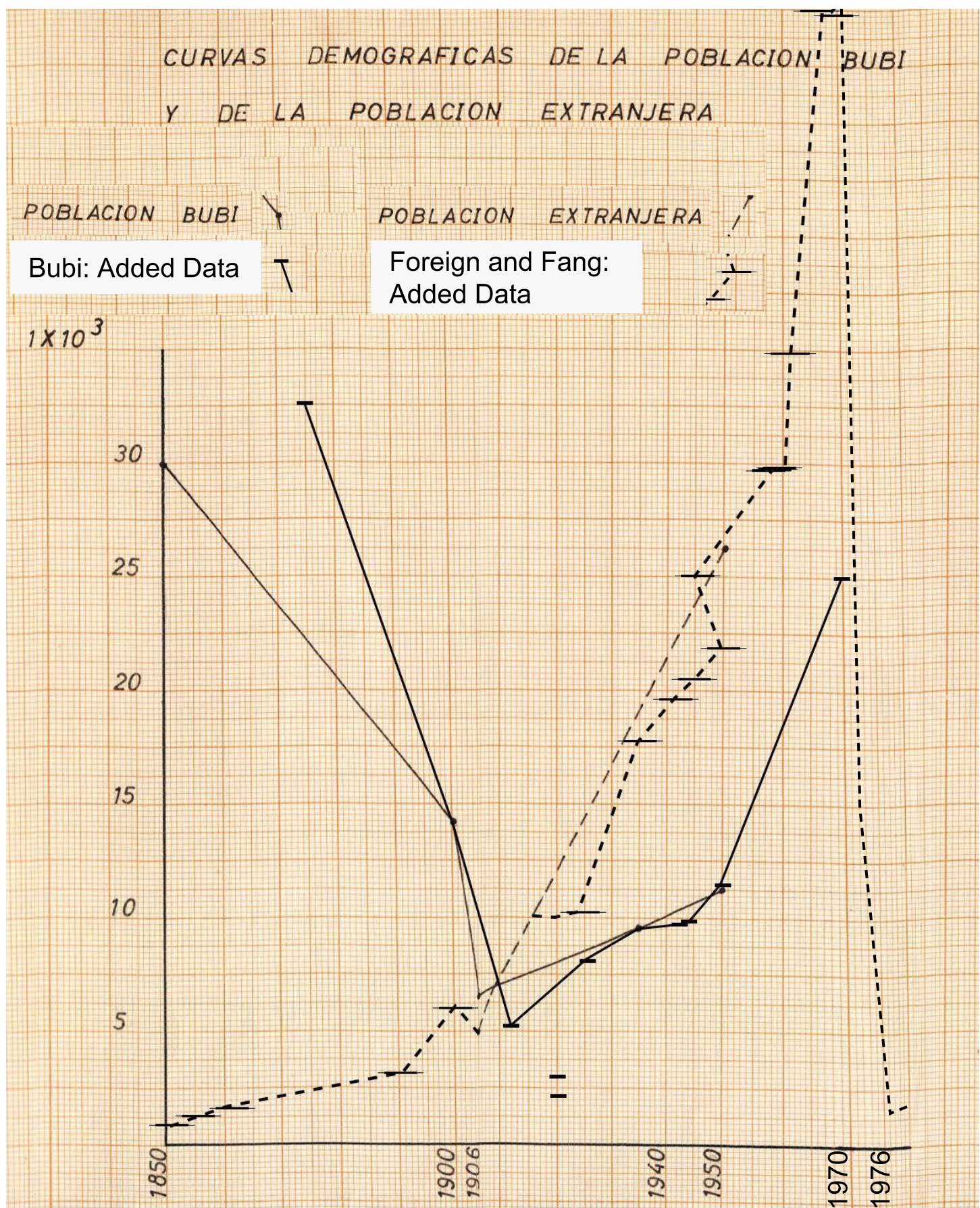

2 adapted from Sanz Casas, 'Problemas de una agricultura colonial', 274, 280. Titled "Curvas demograficas de la poblacion Bubi y de la poblacion extranjera" or "Demographic graph of the Bubi population and of the foreign population." The graph has been adapted and extrapolated in order to visualize the extreme devastation of the Bubi, and to highlight the rapid of growth of immigration, particularly in the post WWII decades. Post-war Bubi growth is a testament to Bubi and Nigerian marriages. Extra data points: Sundiata, From Slaving to Neoslavery, 117, 182; García Cantús, 'Fernando Poo', 585; Terán, Síntesis geográfica, 64; Pélissier, Los territorios españoles de Africa, 48; Crespo GilDelgado, Notas para un estudio antropológico; 30; Wolff, 'Beitrag zur Wirtschaft', 108; Llompart Aulet, Anuario Estadístico, 194; British Consul, Yaounde, 4 May 1961, 'Despatch No.46', TNA, CO 554/2502; United States Department of Labor, Labor Digests on Countries in Africa, xxxii. 


\section{Glossary}

Barracon

Bolsa de trabajo

Bracero

Brigada

Disciplinaria

Cámara

Capataz

Chapear

Curador, Curaduría

Dash

Emancipados

Finca, Finqueros

Fuga, Fugado

Ganchos

Guardia Colonial

Indígenas

Jefe

La recluta

Palabras

Panya

Panyarring

Papel de libertad

Peonaje

Prestación personal
Barracoon, Jails

Labour burse or labour exchange; existed in Rio Muni in 1935

Agricultural contract labourer

Disciplinary Brigades or penal road-gangs

Agricultural Chambers of Commerce or Cámara Agrícola de Fernando Póo

Overseer on the plantations

Clear vegetation with a machete (Spanish-Cuban term)

Labour Officer / Labour Office; unique colonial term connoting protector and tutelage

Advances in relation to contract; generally, ancillary component to any exchange (Pidgin)

2) Status conferred with license allowing an enlarged set of civil and economic rights for 'elite' Africans; never more than 200 people, codified in 1928; equivalent to the status of assimilado in the Portuguese Empire

Plantations, planters

Flight, deserter

Hooks or runners; recruiters who do the leg-work

Colonial Guard; paramilitary force like gendarme; created by the Guardia Civil

Natives (used as a term for all Africans)

Chief

Labour recruitment in relation to el problema bracero

Palavers or legal disputes

España or Fernando Pó (Pidgin)

Commercial Kidnapping; in different contexts also seizure for unpaid debts (Pidgin)

Freedom paper, (given after release or expiry of a contract, valid for 2 weeks); component of pass-laws; 'walk-book' (Pidgin)

Peonage

Corvée; literally personal submission or offering (coined in an 1844 Spanish municipal code; post-feudal, Señorío or manorial corvée was abolished in 1811. It seems term was borrowed from French term prestation, that reinstitutionalized corvée for the state as legislated in 1824 and 1836); term was used in Philippines, Puerto Rico and Spanish 
Guinea, but not in Cuba.

Prima

Problema bracero

Recluta libre

Reclutador

Reengancho, recontratado

Regalo

Vagos y maleantes
Bounty, ancillary bonus or wage advance

The Labour Question

Free recruitment (with and without licenses)

Labour Recruiter (with and without licenses)

Re-hooked labourer, recontracted or signing a second contract

Present or gift (in Spanish Guinea meant wage advance)

Vagrants and miscreants 